\title{
WestVirginiaUniversity
}

THE RESEARCH REPOSITORY @ WVU

Graduate Theses, Dissertations, and Problem Reports

2005

\section{Water quality changes of underground mines in northern West Virginia}

Jennifer Demchak

West Virginia University

Follow this and additional works at: https://researchrepository.wvu.edu/etd

\section{Recommended Citation}

Demchak, Jennifer, "Water quality changes of underground mines in northern West Virginia" (2005).

Graduate Theses, Dissertations, and Problem Reports. 2260.

https://researchrepository.wvu.edu/etd/2260

This Dissertation is protected by copyright and/or related rights. It has been brought to you by the The Research Repository @ WVU with permission from the rights-holder(s). You are free to use this Dissertation in any way that is permitted by the copyright and related rights legislation that applies to your use. For other uses you must obtain permission from the rights-holder(s) directly, unless additional rights are indicated by a Creative Commons license in the record and/ or on the work itself. This Dissertation has been accepted for inclusion in WVU Graduate Theses, Dissertations, and Problem Reports collection by an authorized administrator of The Research Repository @ WVU.

For more information, please contact researchrepository@mail.wvu.edu. 


\title{
WATER QUALITY CHANGES OF UNDERGROUND MINES IN NORTHERN WEST VIRGINIA
}

\author{
Jennifer Demchak
}

\author{
Dissertation \\ Submitted to the Davis College of Agriculture, Forestry, and Consumer Sciences \\ At West Virginia University \\ In Partial Fulfillment of the Requirements for the Degree of \\ Doctor of Philosophy \\ In \\ Agricultural Sciences \\ Jeffrey Skousen, Ph.D., Chair \\ Louis McDonald, Ph.D. \\ John Sencindiver, Ph.D \\ Joe Donovan, Ph.D \\ Paul Ziemkiewicz, Ph.D.
}

Division of Plant and Soil Sciences

Morgantown, West Virginia

2005 


\section{ABSTRACT}

\section{Water quality changes of underground mines in Northern West Virginia}

\section{Jennifer Demchak}

Acid mine drainage (AMD) is a serious problem from both abandoned surface and underground mines, and about 10,000 km of streams have been impacted by AMD in the northeastern U.S. (Pennsylvania, Maryland, Ohio, and West Virginia). Streams in the region have shown improvement over time and this improvement has been partly attributed to reclamation of mined sites and natural attenuation of AMD impacts. This study was initiated to determine the water quality changes from underground mines over time in northern West Virginia. In order to compare chemistry data across years and seasons with varying flow, relationships between discharge rates and acidity values were assessed. Results indicate that water quality from the majority of abandoned, above drainage underground mines did significantly improve over time, some exponentially and some linearly. The amount of improvement varied with coal seams. Graphs plotting flow and precipitation showed the highest flows generally in the spring and low flows in the fall. Acidity concentrations from two underground mines did not change significantly with varying discharge rates, which neither supports previous ideas of a flushing or dilution of acid salts from the mine. One mine, T\&T, showed a slight trend of highest acidity values at high flows, while Omega showed highest acidity at low flows. Additional long term data sets with frequent flow and acidity data will be necessary to confirm these results. 


\section{EXECUTIVE SUMMARY}

Acid mine drainage (AMD) is a serious problem from both abandoned surface and underground mines, and about 10,000 km of streams have been impacted by AMD in the northeastern U.S. (Pennsylvania, Maryland, Ohio, and West Virginia). Streams in the region have shown improvement over time and this improvement has been partly attributed to reclamation of mined sites and natural attenuation of AMD impacts. Therefore, this study was initiated to determine the water quality changes from underground mines over time in northern West Virginia. Water quality data were collected from 44 underground mines that were sampled in 1999 and 2000, and compared to data collected during 1968 and 1980. There were significant water quality differences between years and coal seam, but disturbance had no effect. While $\mathrm{pH}$ was not significantly improved, average total acidity declined 79\% between 1968 and 2000 in the Pittsburgh mines and 56\% in the Upper Freeport mines. Iron decreased an average of 80\% across all sites, while sulfate decreased between 50 and $75 \%$. Twenty of the 44 sites had water quality information in 1980, which served as a midpoint to assess the rate of decline of acidity and metal concentrations. Five of the 20 sites showed an apparent exponential rate of decline in acidity and iron, while 10 of the 20 sites showed a more linear decline. Drainage from five Upper Freeport sites increased in acidity and iron. Above drainage underground mines are not as predictable in water quality improvement as surface mines and below-drainage mines. In total, the drainage from 34 of 44 above drainage sites showed significant improvement in acidity over time. Ten discharges showed no improvement and three got much worse.

Two above drainage underground mines, Omega and T\&T, which had daily flows and frequent analysis of water chemistry, were used to test the effect of flow on acidity concentrations. Both are located near Morgantown, WV and were mined for Upper Freeport coal. They do, however, vary in size, topography, and overburden depth.

Graphs plotting precipitation and flow show the highest flows generally occurring in the spring, with low flows in the fall. The time graphs showed no clear acidity trends with flow. Flow category had no significance on acidity values at T\&T, but in general the highest flows generally had the highest acidity values. Graphical analysis showed a slight trend for increased flow to increase acidity $\left(\mathrm{R}^{2}=0.92\right)$. At Omega, the individual flow category term was not 
significant, but the interaction of flow category with season was significant. This resulted in significantly higher acidity values at low flows at this site.

Significant differences were seen in acidity across years at both sites with acidity concentrations gradually declining over time. Analysis of flow and acidity data from these two mines gave hardly any relationship between flow rates and acidity concentrations. While two ideas have existed about flow rate on discharge acidity concentration from above drainage underground mines (flushing versus dilution), neither idea was supported by this analysis. Additional long term data sets with frequent flow and acidity data will be necessary to confirm these results. 


\section{ACKNOWLEDGEMENTS}

I would like to first thank my major advisor Dr. Jeff Skousen for his encouragement of independent thinking, along with the support and guidance to produce a dissertation of practical importance and implication. I would like to thank my advisory committee of Dr. Louis McDonald, Dr. John Sencindiver, Dr. Joe Donovan, and Dr. Paul Ziemkiewicz for their thoughtful insight and expertise during this project. In addition, I want to thank Jason Stewart for his willingness to always lend a hand and most importantly, his friendship.

Furthermore, I would like to thank my parents for their love and support throughout my life. They instilled in me a belief in myself that anything was possible. I would like to thank my husband Sean for his love, friendship, and endless support (both emotionally and technically). I would also like to extend a sincere thanks to my fellow graduate students and staff for your friendship, guidance, and willingness to help along the way. 


\section{TABLE OF CONTENTS}

ABSTRACT _ ii

EXECUTIVE SUMMARY__

ACKNOWLEDGEMENTS__

TABLE OF CONTENTS _

List of Figures ___ ix

List of Tables __ $\mathrm{x}$

CHAPTER 1: INTRODUCTION___ 1

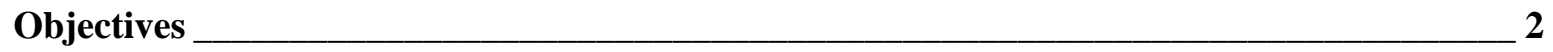

CHAPTER 2: LITERATURE REVIEW__ 3

AMD History ___ 3

AMD Formation and Effects on Aquatic Ecosystems ___ 4

Types of Underground Mines ___ 5

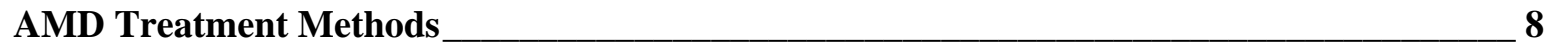

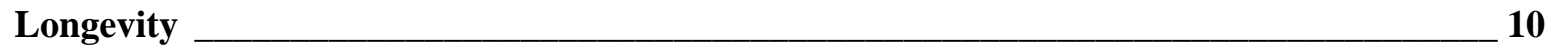

Flow Rate Effects on Acidity Concentrations ___ 13

Literature Cited ___ 15

CHAPTER 3: LONGEVITY OF ACID DISCHARGES FROM UNDERGROUND MINES

LYING ABOVE THE REGIONAL WATER TABLE _ 20

Introduction ___

Materials and Methods ___ 27

1968 Study __ 28

1999-2000 Study ___ 28

Statistical Analysis __ 29

Results and Discussion ___ 30

Flow and Concentration Differences within a Year ___ 30 
Comparisons between 1968 and $2000 \_31$

Comparisons among 1968, 1980, and 1999-2000__ 32

Effects of Disturbance, Mine Size, and Time Since Closure ___ 33

Conclusions____ 35

Acknowledgments ___ 36

Literature Cited ___ 36

CHAPTER 4: FLOW EFFECTS ON ACIDITY AT TWO MINE SITES IN WV: OMEGA

$A N D T \& T+51$

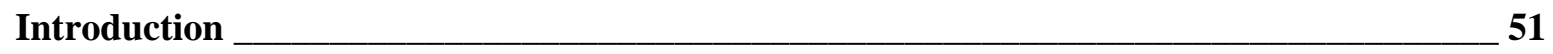

Methods and Materials ___ 54

$\mathrm{T} \& \mathrm{~T}$

Omega _ـ 54

Sampling___ 55

Measured vs. Calculated Acidity ___ 55

Statistical Analysis ___ 56

Results and Discussion

Precipitation Effects on Flow Rate___ 56

Acidity Values Plotted Over Time ___ 57

Year, Seasonal and Monthly Flow Effects on Acidity ___ 58

Daily Flow Effects on Acidity ___ 60

Conclusion ___ 61

Literature Cited ___ 62

CHAPTER 5: DISSERTATION SUMMARY__ 76

\section{APPENDICES}

\section{Appendix A: Location Maps of Underground Mines}

Area Summary ___ A-1

Area $1 \ldots$ A-2

Area 1 (on topo) ___ A-3

Area $2 \ldots$ A-4

Area 2 (on topo) ___ A-5

Area 3

Area 3 (on topo) ___ A-7 
Area 4

Area 4 (on topo)

List of sampling points A-10

\section{Appendix B: Site Descriptions for Underground Mines}

Site Descriptions for Underground Mines B-1

Stream Information and Study Area

Coal Beds B-11

Historical and Additional Data B-12

Appendix C: Water Quality Results for Underground Mines in 1968, 1980, and 1999-2000

Appendix D: ANOVA Results for Precipitation, Flow and Acidity Models for T\&T and Omega

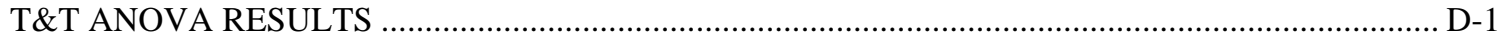

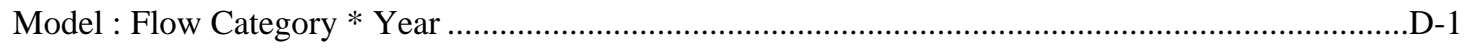

Model: Flow Category * Year* Season .....................................................................................

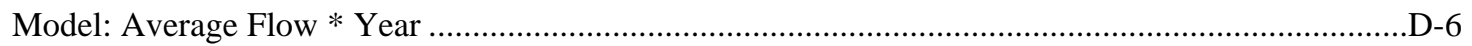

Model: Average Flow * Year * Season ...........................................................................

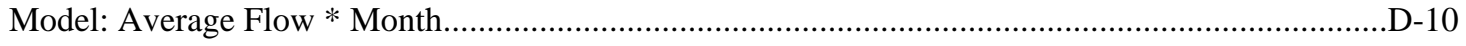

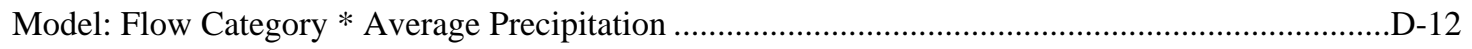

Model: Average Flow * Average Precipitation ....................................................................... 13

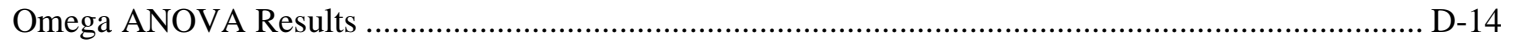

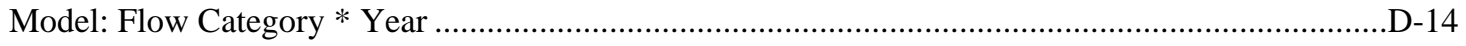

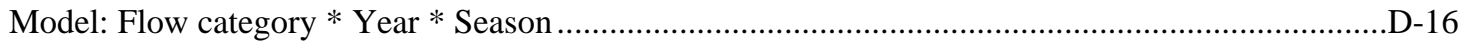

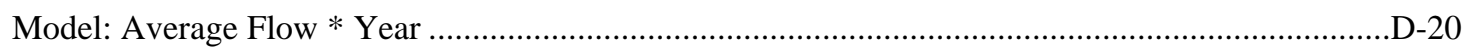

Model: Average Flow * Year * Season .......................................................................... 21

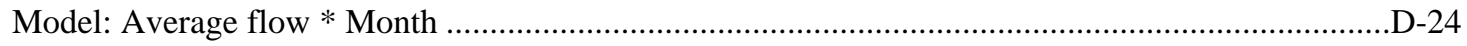

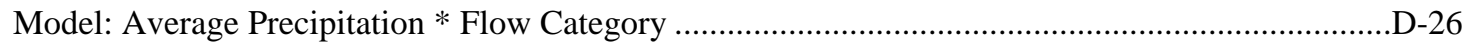

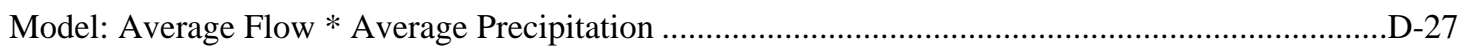




\section{List of Figures}

Figure 3-1. Below drainage vs. Above drainage ...................................................................................... 45

Figure 3-2. Average values for flow, acidity, iron, and $\mathrm{pH}$ across years and months for the T\&T data set............. 46

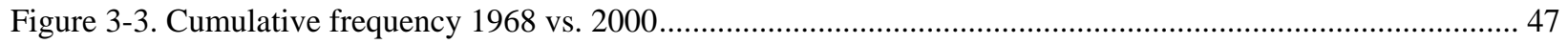

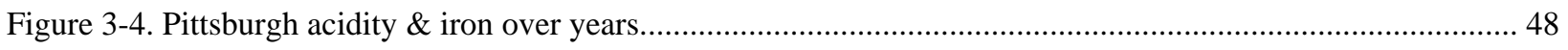

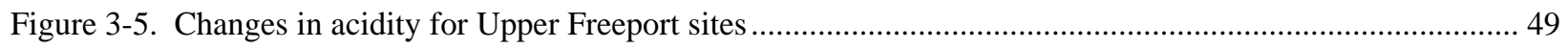

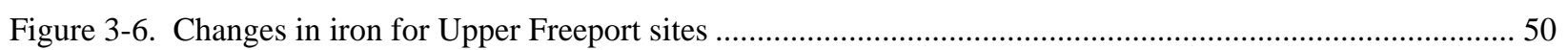

Figure 4-1: Regression analysis of the measured and calculated acidity at the T\&T mine site........................... 70

Figure 4-2: Regression analysis of the measured and calculated acidity at the Omega mine site. ........................ 70

Figure 4-3: Daily flow and precipitation at the T\&T mine site from 10 Nov 1995 to 31 Dec 2003..................... 71

Figure 4-4: Daily flow and precipitation at the Omega mine site from 1 Feb 2000 through 31 Dec 2003.............. 71

Figure 4-5: Acidity concentrations and flow plotted over time at the T\&T mine site using monthly averages......... 72

Figure 4-6: Regression analysis of flow and acidity concentration at the T\&T mine site. .................................. 72

Figure 4-7: Acidity concentrations and flow plotted over time at the Omega mine site using monthly averages...... 73

Figure 4-8: Regression analysis of flow and acidity concentration at the Omega mine site.................................. 73

Figure 4-9: Acidity concentration from 1995 through 2003 years at the T\&T mine site..................................... 74

Figure 4-10: Acidity concentration over seasons at the T\&T mine site......................................................... 74

Figure 4-11: Acidity concentrations over months (January to December) at the T\&T mine site. ........................ 74

Figure 4-12: Acidity concentrations over flow categories (Low, Mid, and High) with a trend line and regression

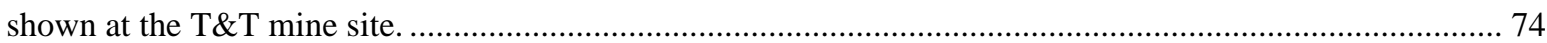

Figure 4-13: Acidity concentration from 1995 through 2003 years at the Omega mine site............................... 75

Figure 4-14: Acidity concentration over seasons at the Omega mine site ................................................... 75

Figure 4-15: Acidity concentrations over months (January to December) at the T\&T mine site.......................... 75

Figure 4-16: Acidity concentrations over flow categories (Low, Mid, and High) at the Omega mine site. .............. 75 


\section{List of Tables}

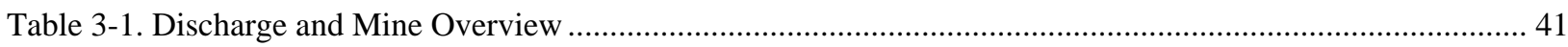

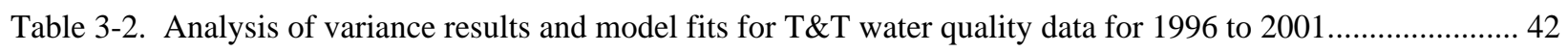

Table 3-3. Correlation coefficients between water quality parameters for the T\&T underground mine site............. 42

Table 3-4. Characterization of T\&T flows and concentrations (1996 to 2001) across all months (January to

December) and during low-flow sampling times (June to September). .......................................................... 43

Table 3-5. Average values for 1968 and 1999-2000 water quality data (two dates) from Pittsburgh and Upper

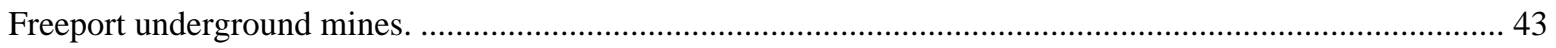

Table 3-6. Average water quality value from Pittsburgh and Upper Freeport underground mines .......................... 44

Table 4-1: Characterization of T\&T flows and acidity (1996 to 2003) using Tukey analysis.................................... 64

Table 4-2: Analysis of variance results and model fits for T\&T water quality data for 1996 to 2003. ..................... 64

Table 4-3: Characterization of Omega flows and acidity (2000 to 2003) using summary statistics and Tukey

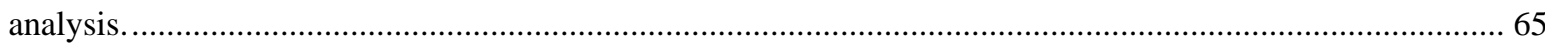

Table 4-4: Analysis of variance results and model fits for Omega water quality data for 2000 to $2003 \ldots \ldots \ldots \ldots \ldots \ldots \ldots . . . . . . .65$

Table 4-5: Description of data categories for T\&T and Omega using flow categories........................................... 65

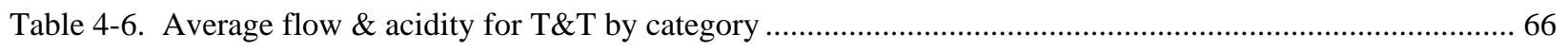

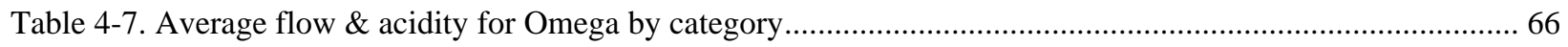

Table 4-8: Flow rates and acidity amounts at the T\&T mine by rainfall event........................................................ 67

Table 4-9: Flow rates and acidity amounts at the Omega mine following dry periods of no rain along with high rainfall events. 


\section{CHAPTER 1: INTRODUCTION}

Surface mining has disturbed approximately 1.8 million ha (4.4 million ac) in the Appalachian Region since 1930 (Barnhisel et al. 2000, Paone et al. 1978, Zeleznik and Skousen 1996). No estimates have been made on the areal extent of underground mining in this region. The West Virginia Department of Environmental Protection (WVDEP) estimates that in West Virginia alone about 610,000 ha (1.5 million ac) have been mined by underground methods, while about 276,000 ha $(682,000 \mathrm{ac})$ have been surface mined in the state (Bennett 1991).

Acid mine drainage (AMD) is a serious problem from both abandoned surface and underground mines. According to the Environmental Protection Agency (1995) approximately $10,000 \mathrm{~km}$ of streams have been affected by AMD in the northeastern U.S. (Pennsylvania, Maryland, Ohio, and West Virginia). Mines abandoned prior to 1977 generate more than $90 \%$ of the AMD in streams and rivers in the region with the majority of this acid drainage coming from underground mines. Acid drainage from abandoned deep mines is problematic and hard to correct because the mines are partially caved and flooded, thereby restricting access, and reliable mine maps are often not available for study.

Many of these acid discharges exist with no responsible parties to treat them and when abandoned they become the responsibility of the state or federal government. Simple and inexpensive treatment approaches are being sought as well as a better understanding of the natural amelioration and reclamation processes that occur to improve water quality over time (Kleinmann et al. 1981). Much work has been done on selection, design, and effectiveness of AMD treatment methods, both active and passive (Hyman and Watzlaf 1995, Hedin et al. 1994). However, changes in water quality over time from surface and underground mines are not as well documented because long-term datasets are not available. In order to determine appropriate remediation strategies, it is critical to determine methods to predict the longevity of these acid discharges.

It has been estimated that acidic water discharges from surface mines for 10-20 years, then gradually decreases as the acid producing salts are leached (Meek 1996). Estimates of acid drainage from underground mines are much more difficult to predict. For underground mines in the U.K. estimates of 10-100 years have been made (Younger 1997). In West Virginia underground mining began in 1742 and continues to the present. Many of today's discharging 
mines were present and abandoned long before the Surface Mining Control and Reclamation Act of 1977 placed regulations and responsibility of mine drainage on the operator; prior to this date, few documents exist relating to the water quality from surface or underground coal mines.

Understanding the history of these mines is vital in determining longevity. Determining water chemistry is the primary step, but research into the size of the mine, years in operation, coal bed mined and pyrite content, coal recovery rate, type of mining, techniques of abandonment, up dip vs. down dip status, roof caving amount and rate, water infiltration rate, water flow through the mined out area, roof cave-in barriers, water impoundment, oxygen content and flux should also be considered. Such information is difficult to locate and relate to a particular mine. The old mines, as stated, are not well documented, but a few mines have sufficient historical data to estimate the longevity of the acid discharge.

\section{Objectives}

1. Determine the water quality changes over time from underground mines in northern West Virginia.

2. Assess the relationship between discharge rates and acidity emanating from underground mines. 


\section{CHAPTER 2: LITERATURE REVIEW}

\section{AMD History}

Acid mine drainage (AMD) is one of the most serious problems facing the watersheds of Appalachia today, affecting over 16,090 km (10,000 miles) of streams (U.S. Environmental Protection Agency 1995). Coal was first mined in the U.S. in Richmond, Virginia in 1750. Coal mining was performed by small operators using only picks and shovels on surface coal outcrops where little soil cover occurred. During the 1800s, the demand for coal increased forcing the development of underground mines. The USDA Soil Conservation Service (1976) estimated that surface mining by 1975 had disturbed about 243,000 ha (600,000 acres) of land. No estimate has been made of the $\mathrm{km}$ of underground tunnels where coal had been removed by underground mining.

The detrimental effects of mine drainage were evident soon after coal was first discovered and excavated. The study of AMD-creating processes began in 1910 and research into treatment using lime and soda ash as neutralizing agents began soon after (Gleason and Russell 1987). The first intensive effort to control AMD was made by the U.S. Public Health Service in the 1930s, where they reduced drainage from underground mines using mine seals (Bennett 1991). In 1947, the role of microorganisms in AMD formation and treatment was established when iron and sulfur oxidizing bacteria were isolated from AMD producing sites (Gleason and Russell 1987). This research led to an understanding of the factors involved in mine drainage formation, which in turn allowed for precautionary measures to be taken when extracting coal. Several states, including Pennsylvania and West Virginia, had regulations governing surface mine reclamation and allowable discharge water quality in the 1950s. With the passage of the Surface Mining Control and Reclamation Act (SMCRA) in 1977, all coal mines came under Federal regulation and had to meet standard effluent criteria. Effluent standards for $\mathrm{pH}$, total suspended solids, Fe, and Mn were established and monitoring of water discharge points from mines was required. The effects of discharged water on receiving streams also had to be evaluated.

In 1966 a large scale regional survey occurred in Appalachia by Biesecker and George (1966). They traveled through nine states from Pennsylvania to Alabama and showed that water quality in 200 of 318 streams was below drinking water standards. Lorenz and Stephan (1969) 
looked at stream water quality as affected by deep mines in Pennsylvania, Ohio, Maryland, West Virginia, Kentucky, Tennessee, and Alabama. They determined that the quality of mine water depends on the thickness and type of overburden. A study by Renton and Hidalgo (1975) showed through artificial leaching that no correlation existed between abundance of pyrite and the amount of acid produced. Rauch et al. (1984) studied the effects of surface mining on ground water quality in northern Preston County, West Virginia. They showed that peak contamination by sulfate and iron in groundwater wells occurred 2 to 4 years after mining ceased, then improvement began.

\section{AMD Formation and Effects on Aquatic Ecosystems}

AMD is formed when overburden or coal containing pyrite is exposed to oxygen and water during underground and surface coal mining. When neutralizing compounds are absent in the overburden, water draining from surface and deep mines can become acidic and contaminated with high concentrations of dissolved Fe, Mn, Al, and $\mathrm{SO}_{4}$ (Edenborn et al. 1993). Metal concentrations in AMD vary and depend upon the disturbed soil and mineral rock composition from which the drainage developed. The type of drainage is highly correlated to the amount and type of pyrite present and the degree of physical weathering that has occurred. Mine drainage may be either net acidic or net alkaline. Net acidic drainage lacks adequate buffering capacity and net alkaline drainage contains net neutralizing potential, generally as $\mathrm{HCO}_{3}{ }^{-}$, to accept proton acidity (Robb and Robinson 1995). The oxidation of iron sulfides $\left(\mathrm{FeS}_{2}\right)$ creates the high concentration of iron, sulfate, and proton acidity in the water, but the sulfuric acid dissolves other nearby minerals causing high concentrations of aluminum, additional iron, manganese, and other elements.

AMD from surface and underground mines pollutes surrounding receiving streams with acid and metals, thereby destroying aquatic and streambed habitat. The first noted effects of AMD are red-yellow precipitates of iron hydroxide in streambeds and the toxic effects of acid and metals on fish and other aquatic flora and fauna in receiving streams (Paine 1987). As iron-laden AMD reaches a surface stream, the usually higher quality stream neutralizes some of the acidity causing a rise in water $\mathrm{pH}$. When the $\mathrm{pH}$ rises above $3.5, \mathrm{Fe}^{3+}$ in the water forms $\mathrm{Fe}(\mathrm{OH})_{3}$, which then precipitates and coats stream bottoms. The iron precipitate is commonly called "yellowboy." AMD has numerous effects on the stream including sediment and solid deposition and 
coating, oxygen removal, acidification, depletion of neutralizing capacity, and a decrease in light penetration, which in turn affects photosynthesis and the clarity of the water. The "yellow-boy" solid precipitate smothers out stream bottom dwelling insects, thereby, decreasing food resources for fish (Robb and Robinson 1995). A direct toxic effect of dissolved Fe and Al may also occur reducing the diversity of fauna within the streams (Jarvis and Younger 1997). AMD is also devastating to public-use water supplies, recreation, and agriculture and industrial use. Other metal oxides can also precipitate and may fill in spaces between rocks, depleting organism habitat (Robb and Robinson 1995). $\mathrm{Al}(\mathrm{OH})_{3}$ appears as a white solid, while $\mathrm{MnO}_{2}$ appears as a black coating on sediments.

In the eastern U.S., abandoned mines generate more than $90 \%$ of the AMD in streams and rivers and most of the drainage stems from underground mines (U.S. Environmental Protection Agency 1995). Drainage quality from underground mines depends on the relative proportion of acid producing and acid consuming minerals (pyrites and carbonates respectively in the coal and surrounding geologic material, and less on the total overburden chemistry (Skousen et al. 2002).

On surface mines, AMD can discharge from overburden material that has been blasted apart and moved to reach the coal, thereby exposing pyritic material. The porosity and hydraulic conductivity of the materials in a surface mine backfill are greater than those of consolidated rock overburden that existed prior to mining, and changes in water flow paths are evident (Caruccio 1968). Water tends to flow through more permeable acid sandstones than calcareous shales. The water continues downward until it encounters a barrier, the coal pavement or other compacted or slowly permeable layer. Water emanating from a surface mine backfill will reflect only the chemistry of the rock types encountered, and probably not the overall chemistry of the entire overburden (Ziemkiewicz and Skousen 1992).

\section{Types of Underground Mines}

Underground mining will continue for years to come because $70 \%$ of the coal in the U.S. is attainable only by underground mining (Meyers 1981). Different mining methods were and are used for coal removal depending on the depth of the overburden covering the coal bed and depending on the position of the coal in relation to the land surface. Drift mines are most typical at sites where the coal outcrops at the surface and remains horizontal to the land surface. Drift mines were the most common underground mine before advances in technology allowed access 
to deeper coal. Another underground mining method is a slope mine. Slope mines are used where there is some overburden above the coal and an incline tunnel is needed. The coal is then removed and brought to the surface on a conveyor belt. A further development was shaft mines. These are used on coal beds covered by thick overburden, which need vertical shafts to enter the mine (Meyers 1981). Today's underground mining includes drift, slope and shaft mine entries, and coal extraction methods including, long-wall and short-wall mining machines and advance and retreat continuous mining machines. Still other underground mines use traditional blasting and electric coal shovels to load coal. All are used as necessary to obtain the coal as economically and safely as possible.

A problem associated with almost all deep mines is subsidence, but it is usually only noticeable at the land surface when the overburden is less than 45 meters thick. However, subsidence has been reported in areas where the cover was up to 180 to 215 meters (Hobba 1981). Continued subsidence into underground mine void space increases cracks and fissures to the surface, which increases the potential for surface water recharge into mine water pools, along with increasing the oxygen intrusion into the mine. Subsidence may also increase the hydraulic conductivity and inter-connectedness of mines, which can cause an increase in underground mine drainage and seasonal water table fluctuations (Hobba 1981). As cracks and fissures open to the surface and the roof falls, pyritic material in the roof and in coal pillars (left to support the roof) break apart, thereby exposing fresh surfaces of pyrite to react perpetuating AMD discharge.

Some coal beds are located below the regional water table or below the elevation of major streams and rivers, and these coal beds are termed below-drainage coal. Mining of this coal requires continual pumping of the water that constantly fills the mined area to allow men and machines to work. As the mine progresses, more pump stations are added to keep the water out of the mine. Once mining is finished, the pumps are shut off and the mine voids fill with water. It is assumed that once the mine voids are filled with water, the water quality will return to predisturbance levels within a few years after abandonment. However, in acid-producing, belowdrainage deep mines, pre-disturbance water quality may not re-establish for several decades.

Some coal beds are situated above the regional water table. Underground mining of these beds sometimes requires continual or sporadic pumping to remove infiltrating water. Since these mines drain, water moves toward the lowest elevational point in the mine. These mines are called above-drainage deep mines. 
There are two types of above-drainage deep mines: mines that were developed from a low elevational point and progressively mined up-dip (where the portal entrance is the lowest elevational opening in the mine) and those that were developed at a high point and mined downdip (where the portal entrance is the highest elevational opening in the mine).

Up-dip, above-drainage deep mines continually drain and do not fill with water unless some barrier or seal is placed near the entrance or portal face. If a seal is placed, the possibility of blowouts or water blasting out of the mine at the weakest point along the contour is a potential hazard. Therefore, most up-dip, above-drainage deep mines are closed with wet seals, which allow water to continually flow out of the mine through pipes in the seal. Once abandoned, roof falls or other caving material may block water and air flow in the mine, and cause small pools of water to form (Perry, personal communication).

Down-dip, above-drainage deep mines may fill with water since there is no proscribed outlet for the water. Theoretically, the down-dip mine should fill with water (like a below-drainage deep mine) and any water that comes from the mine must either flow out the top of the water pool at the portal face or the water may seep through the hillside and come out at some lower elevational point than the portal. Sufficient barrier or outcrop coal must be left in order to withstand the hydraulic head in the mine or else a "blow-out" of water may occur along the hillside contour, thereby draining the mine. With a blow-out, the previously down-dip mine becomes an up-dip, above-drainage deep mine. Down-dip mines, if the mine is full of water, may improve in water quality over time much like a flooded, below-drainage underground mine (Perry, personal communication).

Above-drainage deep mines may contribute polluted water for a long time period because pyrite materials in coal pillars left in the mine for roof support and in the coal pavement and overlying material are continually in contact with air and water. As water flows through the mine downward to the portal in an up-dip mine, the water picks up acidity and metal salts from pyrite oxidation. This water contamination process continues until the pyrite is exhausted along those flow paths. In underground mining, flooding the mine is the preferred method of reducing contamination because it is assumed that acid generation ceases when oxygen is depleted. So in most cases, flooding is assumed to eventually allow the water to become alkaline, but it will not return to its pre-mining quality. It will be highly mineralized due to extensive leaching (Perry, personal communication). 
In watersheds where many abandoned deep mines occur, the deep mines serve as a constant source of water to streams, sometimes called baseflow (Hobba 1981). During drier periods of the year, a larger degree of stream flow comes from deep mine drainage or baseflow, thereby causing very acidic water. During wetter periods, deep mine discharges, making up the majority of the baseflow, are diluted by ephemeral springs and seeps, and also by runoff, thereby resulting in improved water quality in streams. However, stream clean-up efforts must effectively deal with improving the water quality during baseflow conditions (improving the deep mine discharges) or else any enhancement in stream quality and aquatic habitat will be transitory and destroyed each time rainfall declines or is irregular.

\section{AMD Treatment Methods}

The potential for AMD formation is widespread, so measures should be taken during mining to preclude or reduce the problem. Treating the acid rock directly and stopping or retarding acid production is a practice that has been implemented on many surface mines. The most common preventative measure is the use of alkaline amendments, such as limestone, fluidized bed combustion ash (FBC), kiln dust and steel slag (Brady et al. 1990; Perry and Brady 1995; Rich and Hutchinson 1990; Rose et al. 1995). These alkaline materials are blended with the acidproducing material to increase the neutralization potential or to act as seals or stabilizers. Surface reclamation is also useful for contaminated sites. Water quality improvements can occur through slope modification, erosion prevention, the building of sedimentation basins, and revegetating the site.

With underground mines, opportunities for alkaline amendment are limited. Rock dust and other lime products may be layered on underground floors, ceilings, and mine walls, but this technique has limited success in underground mines with high pyrite levels. Another technique being used after mining involves injection of alkaline materials to fill mine voids with nonpermeable materials (Burnett et al. 1995). They act to decrease or stop oxygen intrusion and water infiltration.

Another important technique to aid in the improvement of water quality from abandoned areas is remining. In the process of remining, the operator returns to an area that has already been mined for further coal removal. Terms like daylighting and underground mine removal have also been used to describe remining. It has been shown that remining reduces acid drainage by 
decreasing water infiltration, covering exposed acid-producing material with soil materials, and removing coal, which is a major source of pyrite (Griffiths et al. 2001, Richardson and Doughterty 1976). Hawkins (1994) studied 57 discharges from 24 previously abandoned, remined sites in Pennsylvania and found contaminant loads were either reduced or unchanged after remining occurred. Reduction in loads resulted primarily from decreased flow rather than large reductions in contaminant concentrations.

Unfortunately preventative measures have not always been used or may not have been $100 \%$ effective. Through the years, many treatment technologies have been developed for AMD remediation and currently there are a number of organized efforts in Appalachia using both active and passive treatment methods on a watershed scale. Active treatment methods incorporate the use of mechanized procedures for the addition of alkaline materials and require constant monitoring and maintenance. Basic chemicals are used as additives to increase the $\mathrm{pH}$ and cause the precipitation of metals, such as iron and aluminum. The chemicals commonly used are $\mathrm{Ca}(\mathrm{OH})_{2}$ (hydrated lime), $\mathrm{NaOH}$ (caustic soda), $\mathrm{NH}_{3}$ (ammonia), $\mathrm{CaO}$ (pebble quicklime) and $\mathrm{Na}_{2} \mathrm{CO}_{3}$ (soda ash) (Faulkner 1997, Skousen et al. 1990). Other active treatment methods include dissolved air flotation and ion exchange devices, flocculants, coagulants, and oxidants (Skousen et al. 2000). Active methods are successful, but expensive. It is not uncommon for water treatment costs to exceed $\$ 200,000$ per year at AMD sites using active treatment. Another concern is the large volume of sludge produced from the precipitation of metals. Disposal costs for the sludge add to the cost of chemical treatment. Active methods may also cause environmental damage because potentially harmful chemicals are used. The high cost and possible side effects of active treatment can be avoided by the use of passive treatment systems.

Passive treatment systems, which require only limited maintenance, are an alternative approach to active treatment methods. They require no input of manufactured chemicals and have lower operation and maintenance costs. A downside is that they do require longer retention times and larger treatment areas (Hedin et al. 1994). Passive systems include constructed wetlands, ALD's vertical flow ponds, open limestone channels, diversion wells and bioremediation. Most passive systems are designed to encourage oxidation processes and the precipitation unwanted metals, while increasing the $\mathrm{pH}$ (Robb and Robinson 1995). 


\section{Longevity}

It is vital to determine the origin of the deep mine discharges and whether the discharges have improved over time and vary with seasonal rainfall. A prediction of the longevity of acid mine discharges is needed to determine the most appropriate treatment technology. Studying longevity will help predict the time scale at which present loading rates will continue and the length of time the metal loadings will be at polluting levels. Determining the levels of acid discharge over time may provide an estimate of active treatment length, and when the system can be switched to passive treatment. Surface mine discharge longevity has been studied in more detail than underground mines, mainly due to the amount of data and historical information that can be collected.

Meek (1996) stated that acid generation at surface mines have a defined life of 16-20 years. During the subsequent 20 years after reclamation, the quality of the acid discharge begins to improve until all the acid salts are leached from the rocks by natural precipitation. Over a period of 20 years, the raw water quality could reach levels similar to pre-mining levels.

AMD discharge longevity from underground mines is less understood, but studies have been conducted in order to predict discharge longevity. Younger (1997) in the United Kingdom has conducted work on planning remediation based on an understanding of the physical and chemical processes that govern pollutant release over time. Younger (1997) states the longevity of underground minewater pollution is based on two types of acidity: 1) vestigial acidity, which occurs from 'geochemical trauma' as the mine voids fill with water the first time taking ferrous and ferric hydroxysulfates into solution, and 2) juvenile acidity, which occurs from the ongoing pyrite oxidation due to fluctuations in the water table. Vestigial acidity is thought be produced in the first 40 years, while juvenile acidity may persist for hundreds of years. The longevity at a given site is dependent on the rate of depletion of both the vestigial and juvenile acidity. Vestigial acidity is affected by the volume of the flooded mine, the hydraulic conductivity, and the rate of recharge. Juvenile acidity is determined by the amount of pyrite oxidation that is occurring above the water table.

Younger states four main conclusions from his research: First, the poorest water quality from uncontrolled mines occurs within the first 40 years. Second, where rainfall is high or interconnected workings are minimal, the worst pollution occurs within the first 10-20 years. Third, asymptotic levels occur for iron at 10 to $30 \mathrm{mg} / \mathrm{L}$; and fourth, higher iron and acidity 
levels occur where water table fluctuations are extensive and where pyrite concentration is high (Younger 1997).

Other models and predictions have been made concerning longevity of AMD from underground mines. The former British Coal Corporation uses a 'rule of thumb' (for belowdrainage mines) that states that the iron concentration in an uncontrolled mine will decrease by $50 \%$ in each subsequent period equal to that taken for the abandoned workings to fill with water. For example, if 10 years is required for a mine to fill with water, the rule of thumb states that iron concentration will decrease by half every 10 years. This is simulating an exponential decay (Glover 1983). Frost (1979) reported that chronic pollution from underground mines will last no longer than five years. Frost's conclusions are based on a convective mass transfer process where an exponential decline in the concentration of oxidized products occurs. This model is based only on a constant volume of flooded workings, because the rise and fall of the water table can flush out further products. Frost's model can be discredited because there are discharges known to have released pollution for more than 70 years.

Others have stated that the most severe drainage occurs within the first few decades and even the largest systems settle to lower levels within 40 years. A circum-neutral $\mathrm{pH}$ is reached within 30 years, and after 40 years the iron concentrations are less than $40 \mathrm{mg} / \mathrm{L}$ (Wood et al. 1999). Jones et al. (1994) also states that minewaters in Pennsylvania changed from acidic to neutral over a period of decades. These 40-year reductions in pollution from deep mine drainages do not occur from shallow drift mines and spoil heaps, where ventilation facilitates pyrite oxidation and contamination continues for decades until the pyrite is exhausted (Younger et al. 1997).

Other factors affect the longevity of discharges. The rate of dilution is greatest where the volume of the mine is small, water flow out of the mine is high, and recharge rate is high (Younger 1997). Another concern is the fluctuation of water levels due to seasonal variations in precipitation. During low water levels, pyrite oxidation forms iron-hydroxysulfate solids, which settle on coal and rock surfaces due to evaporation. When the water levels rise, these salts are dissolved and released into the mine pool. Pyrite oxidation then continues to occur on the clean mineral surfaces producing a continuing cycle of acidity production (Younger 1997).

In mines below the water table, contaminated water frequently displays stratification during groundwater rebound (Ladwig et al. 1984). A slow mixing of water at various depths occurs between the dilute, newly-recharged waters at the top of the mine pool and the denser, deeper 
waters containing high dissolved solids. Depending on the location of discharge (whether pumped from low levels in the mine pool, or discharged freely at the top of the pool), the water quality coming from the same mine pool may be quite variable.

Lambert and Dzombak (2000) located three underground discharges in the Uniontown Syncline of Pennsylvania with distinct flooding histories. This study used underground mines in the Pittsburgh coal seam, one of the coal seams during this study. Water quality measurements had been taken in 1974 and 1999 in each mine. A flooded below-drainage mine closed in 1934 (40 and 65 yrs had passed since closure) had a pH of 6.0 in 1974 and 6.4 in 1999, Fe decreased from 45 to $25 \mathrm{mg} / \mathrm{L}$, and sulfate was $1700 \mathrm{mg} / \mathrm{L}$ in 1974 and 1000 in 1999 (net alkaline water). In a flooded below-drainage mine that was closed in 1970 (instead of 1934), $\mathrm{pH}$ increased from 3.1 in 1974 to 5.9 in 1999 , Fe decreased from $140 \mathrm{mg} / \mathrm{L}$ to $70 \mathrm{mg} / \mathrm{L}$, while sulfate decreased from $2000 \mathrm{mg} / \mathrm{L}$ to $900 \mathrm{mg} / \mathrm{L}$ in 1999 (changed from strongly acidic water to slightly acidic water). Therefore, the researchers concluded that underground mine water quality changed from acidic to alkaline within 30 years after closure and flooding in their geologic setting. Water $\mathrm{pH}$ from an unflooded above-drainage mine closed in 1934 was 3.0 in 1974 and 3.5 in 1999, while Fe decreased from $10 \mathrm{mg} / \mathrm{L}$ in 1974 to <2 in 1999 and sulfate declined from $800 \mathrm{mg} / \mathrm{L}$ in 1974 to $600 \mathrm{mg} / \mathrm{L}$ in 1999. Water in all cases was net acidic from the unflooded mine. Therefore, unflooded above-drainage areas improved in drainage quality, but still remained net acidic (albeit with lower metal concentrations) 60 years after closure. Other researchers have found similar results in this region (Brady et al. 1998, Capo et al. 2001).

Donovan et al. (2000) monitored the water quality of a large underground mine pool in a setting similar to that of Lambert and Dzombak (2000). The Montour mine, and underground Pittsburgh coal seam mine in PA, had a section flooded in 1970 and also a section that was flooded in 1982. Water conditions in the connected mine pool were strongly acidic $(\mathrm{pH} \sim 3.0$, acidity $2200 \mathrm{mg} / \mathrm{L}$ ) for the first two years after the final flooding in 1982, after which acidity began to decline exponentially. Surprisingly, seven years after flooding (five years after peak acidity concentrations), the water in the mine pool became net alkaline and has stabilized at a $\mathrm{pH}$ of 6.4, net alkalinity at $200 \mathrm{mg} / \mathrm{L}$, and iron around $60 \mathrm{mg} / \mathrm{L}$. The good quality water in the 1970 flooded mine probably caused rapid neutralization of the water in the 1982 flooded mine.

Problems in models and comparisons occur due to lack of data or inadequate mine maps of the underground mines. Public mine records are useful for finding physical data relating to the 
mines, but most lack subsurface water characteristics. Another problem is that waters sampled during mining are different than those that emerge after flooding of the mine has occurred (Younger 1994). Caution must be therefore taken when researching a site to assure accurate comparisons.

\section{Flow Rate Effects on Acidity Concentrations}

It is apparent that precipitation influences the discharge rate of underground mines. Most recharge occurs in the fall, winter and especially spring causing increased flow rates as seen in the Appalachian Plateau Sandstone of central Pennsylvania (O’Driscoll et al. 2005). Wendland (2001) reported groundwater response within the month of precipitation events or one to two months later, with recovery being reached another one to three months in the future, depending on the season. During drought conditions, much longer recovery times are needed for increased discharge rate (Wendland 2001).

Lopez and Stoertz (2001) studied the behavior of water composition and volumetric discharge of three up-dip mines that had different areas, discharge rates and concentrations of contaminants. They reported a 1 to 4 day time lag between precipitation and peak discharge in updrift mines in the Appalachian region. However, evidence by Borek et al (1991) contradicts this report. Studying underground mines in Randolph County, WV, they found that the highest flows were seen even when precipitation was below normal for a particular year.

Seasonal changes in water quality from above-drainage underground mines have been reported, including changes in $\mathrm{pH}$, acidity, and metal concentrations. Pigati and Lopez (1999) reported that the observed seasonal variations in water chemistry from the above-drainage, 126ha Majestic Mine in $\mathrm{OH}$ supported the "spring flush" idea. This idea involves flushing of acidity and metals deposited on surfaces during summer and fall (seasonal dry months in this region) by late winter-early spring snowmelt and rainfall. Therefore during the high recharge and discharge season of February to May, the high water flows carry high concentrations of acidity and metals. This is opposed to a "high concentration at low flow" idea, where the worst drainage from underground mines happens at base flow conditions (dry months) where acid and metals are thought to be concentrated and not diluted by infiltrating water during recharge events (Skousen and Ziemkiewicz 1996). 
As presented by Demchak et al. (2004), the Omega Mine, a 68-ha above-drainage underground mine of the Upper Freeport coal bed in northern WV, was mined during the 1980s. In 1992, breakout of AMD caused mine closure, and flows and acidity concentrations were recorded continuously for the ensuing six years (GAI Consultants 2001). Acidity was highest during February to May ( 4,500 mg/L) compared to about 3,800 mg/L during June to January. However, variation in the acidity values across both time periods was high. Above drainage mines, based on these and other examples, appear to discharge their worst acid and metal concentrations during high flow seasons (spring flush), with improved water quality during dry periods.

Alternatively, Griffiths et al. (2001) indicate at the Arnot underground mine in Tioga County, PA, that as the discharge rate increased, acidity decreased. This mine interestingly did not experience seasonal patterns, which may be explained by the wide range of "spring thaws" anytime from February to April skewing the trend. Lopez and Stoertz, (2001) suggest mine discharge chemistry is relatively uniform through time, suggesting equilibrium control on chemistry within the mine or a well mixed pool. They report, using studies conducted in the Monday Creek watershed in Ohio that minimal evidence exists for dilution of chemistry by high flows. They state that after the first high flow after baseflow, only a slight increase in concentration is seen due to the flushing of stored reaction products.

It seems evident that discharge chemistry from underground mines is affected by several factors, and efforts to determine the changes in water quality over time require accounting for these factors. First, the season of sampling is important to consider due to varying recharge potential within the mine. However, conflicting results from other studies do not indicate that a particular time of year of sampling will produce accurate acidity results for a particular mine. Part of the problem lies in the fact that two distinct discharge periods are being documented in the WV region: February to May and June to September. Flows in October, November, December and January from underground mines are especially hard to predict because these months alternate between very high flows like those of February to May and very low flows like those from June to September (GAI Consultants 2001, Pigati and Lopez 1999). In fact, evidence is mounting that acidity does not vary significantly with flow. 


\section{Literature Cited}

Barnhisel, R., R. Darmody, and L. Daniels. 2000. Reclamation of drastically disturbed lands. Agronomy No. 41. American Society of Agronomy. Madison, WI.

Bennett, L. 1991. Abandoned Mines: Report from WV. EPA Journal 17:16-18.

Biesecker, J.E. and J.R. George. 1966. Stream water quality in Appalachia as related to coal mine drainage, 1965. US Geological Survey Circular 526, \#M981.

Borek S. L., T. E. Ackman, G. P. Watzlaf, R. W. Hammack, and J. P. Lipscomb. 1991. The long-term evaluation of mine seals constructed in Randolph County, W.V. in 1967. In: Proceedings of the 12th Annual West Virginia Surface Mine Drainage Task Force Symposium, April 3-4, 1991, Morgantown, W.V.

Brady, L., M.W. Smith, R.L. Beam, and C.A. Cravotta. 1990. Effectiveness of the use of alkaline materials at surface coal mines in preventing or abating acid mine drainage: Part 2. Mine site case studies. pp. 227-241 In: Proceedings, 1990 Mining and Reclamation Conference. West Virginia University. Morgantown, WV.

Brady, K.B., R.J. Hornberger, and G. Fleeger. 1998. Influence of geology on postmining water quality: northern Appalachian Basin. pp. 8-1 to 8-92 In: Coal Mine Drainage Prediction and Pollution Prevention in Pennsylvania. PA Department of Environmental Protection. Harrisburg, PA.

Burnett, J.M., M. Burnett, P. Ziemkiewicz, and D.C. Black. 1995. Pneumatic backfilling of coal combustion residues in underground mines. In: Proceedings, 16th Annual Surface Mine Drainage Task Force Symposium. Morgantown, WV.

Capo, R.C., W.R. Winters, T.J. Weaver, S.L. Stafford, R.S. Hedin, and B.W. Stewart. 2001. Hydrogeologic and geochemical evolution of deep mine discharges, Irwin Syncline, Pennsylvania. In: Proceedings of the $22^{\text {nd }}$ West Virginia Surface Mine Drainage Task Force Symposium, April 3-4, 2001. Morgantown, WV.

Caruccio, F. 1968. An evaluation of factors affecting acid mine drainage production and the groundwater interactions in selected areas of western Pennsylvania. pp. 107-151. In: Proceedings of $2^{\text {nd }}$ Symposium of Coal Mine Drainage Resources. Pittsburgh, PA.

Demchak, J., J. Skousen, and L.M. McDonald. 2004. Longevity of acid discharges from underground mines lying above the regional water table. J. Environ. Qual. 33: 656-668. 
Donovan, J., B. Leavitt, E. Werner, E. Perry, and K. McCoy. 2000. Long-term hydrogeological and geochemical response to flooding of an abandoned below-drainage Pittsburgh coal mine. In: Proceedings of the $21^{\text {st }}$ West Virginia Surface Mine Drainage Task Force Symposium, April 4-5, 2000. Morgantown, WV.

Edenborn, H.M., L.A. Brickett, D.H. Dvorak, and S.L. Edenborn. 1993. Monitoring iron and manganese diagenesis in constructed wetlands with continuous gradient gel. pp 287-297. In: Proceedings of the Minerals, Metals, and Materials Society.

Faulkner, B.B. 1997. AMD inventory in West Virginia. In: Proceedings of the $18^{\text {th }}$ West Virginia Surface Mine Drainage Task Force Symposium, April 15-16, 1997. Morgantown, WV.

Frost, R.C. 1979. Evaluation of the rate of decrease in the iron content of water pumped from a flooded shaft mine in County Durham, England. J. Hydrology 40:101-111.

GAI Consultants. 2001. Omega Mine injection program: Monongalia County, West Virginia. Electric Power Research Institute, Inc. (EPRI), Allegheny Energy Supply, and the U.S. Department of Energy. Document \#1004032. USDOE. Pittsburgh, PA.

Gleason, V.E. and H.H. Russell. 1987. A history of acid mine drainage research from 19101948. In: Proceedings of AMD Seminar/Workshop. Halifax, Nova Scotia.

Glover, H.G. 1983. Mine water pollution-an overview of problems and control strategies in the United Kingdom, Water Science Technology 15: 59-70.

Griffiths, J.C., R.J. Hornberger, K. Miller, and M.W.Smith 2001. Statistical analysis of abandoned mine drainage in the assessment of pollution load ("The Griffiths Report"). EPA821-B-01-014.

Hawkins, J.W. 1994. Assessment of contaminant load changes caused by remining abandoned coal. pp. 20-29. In: International Land Reclamation and Mine Drainage Conference, USDI, Bureau of Mines SP 06A-94. Pittsburgh, PA.

Hedin, R.S., R.W. Nairn, and R.L.P. Kleinmann. 1994. Passive treatment of coal mine drainage. Bureau of Mine Information Circular, IC9389, US Dept. of the Interior.

Hobba, W.A. 1981. Effects of underground mining and mine collapse on the hydrology of selected basins in WV. USGS, Report of Investigation, RI-33.

Hyman, D.M. and G.R. Watzlaf. 1995. Mine drainage characterization for the successful design and evaluation of passive treatment systems. In: Proceedings, 17th Annual Conference of the National Association of Abandoned Mine Lands, October 1995. French Lick, IN. 
Jarvis, A.P., and P.L. Younger. 1997. Dominating chemical factors in minewater induced impoverishment of the invertebrate fauna of two streams in Durham Coalfield, UK. Chemistry and Ecology 40: 249-270.

Jones, P.M., S.M. Mulvay, and D. Fish. 1994. The role of sulfate and ionic strength on the shift from acid to alkaline mine drainage in southwest Pennsylvania. pp. 289-295 In: Proceedings of the International Land Reclamation and Mine Drainage Conference and the Third International Conference of the Abatement of Acid Mine Drainage. Vol. 2: Mine Drainage. US Bureau of Mines Special Publication. SP 06B-94.

Kleinmann R.L.P., D.A. Crerar and R.R. Pacelli. 1981. Biogeochemistry of acid mine drainage and a method to control acid formation. Mining Engineering 33:300-305.

Ladwig, K.J., P.M. Erickson, R.L.P. Kleinmann, and E.T. Posluszny. 1984. Stratification in water quality in inundated anthracite mines, eastern Pennsylvania. U.S. Bureau of Mines Report of Investigations RI 8837.

Lambert, D.C., and D.A. Dzombak. 2000. Evaluation of natural amelioration of acidic deep mine discharges in the Uniontown Syncline, Pennsylvania. In: Proceedings of the $21^{\text {st }}$ West Virginia Surface Mine Drainage Task Force Symposium, April 4-5, 2000, Morgantown, WV.

Lopez, D.L. and M.W. Stoertz. 2001. Chemical and physical controls on waters discharged from abandoned coal mines. Geochemistry: Exploration, Environment, Analysis 1: 51-60.

Lorenz, W.C. and R.W. Stephan. 1969. Factors that affect the formation of coal mine drainage pollution in Appalachia. pp. cc 1-cc 17. In: Stream Pollution by Coal Mine Drainage in Appalachia. Federal Water Pollution Control Administration. US Printing Office, Washington, D.C.

Meek, F.A. 1996. Evaluation of acid prevention techniques used in surface mining. Chapt. 11. In: Acid Mine Drainage Control and Treatment. National Mine Land Reclamation Center, Morgantown, WV.

Meyers, R.A. 1981. Coal Handbook. Marcel Decker, Inc. NJ \& Basel.

O’ Driscoll, M.A., D.R. DeWalle, K.J. McGuire, and W.J. Gburek. 2005. Seasonal variations and groundwater recharge for three landscape types in central Pennsylvania, USA. $J$. Hydrology. 303: 108-124.

Paine, P.J. 1987. Environment Canada. In: Proceedings of AMD Seminar/Workshop. Halifax, Nova Scotia. 
Paone, J., P. Struthers, and W. Johnson. 1978. Extent of disturbed lands and major reclamation problems in the United States. pp. 11-22. In: F.W. Schaller and P. Sutton (eds.), Reclamation of Drastically Disturbed Lands. American Society of Agronomy. Madison, WI.

Perry E.F., and K.B. Brady. 1995. Influence of neutralization potential on surface mine drainage quality in Pennsylvania. In: Proceedings, $16^{\text {th }}$ Annual Surface Mine Task Force Symposium, April 4-5, 1995, Morgantown, WV.

Perry, E.F. personal communication. Office of Surface Mining.

Pigati, E., and D. Lopez. 1999. Effect of subsidence on recharge at abandoned coal mines generating acidic drainage: the Majestic Mine, Athens County, $\mathrm{OH}$. Mine Water and the Environment 18(1): 45-66.

Rauch, H.W., W.N. O'Steen, G. Ahnell, and D.F. Giannatos. 1984. Predictions of aquifer dewatering over underground mines in the Pittsburgh, Sewickley, and Upper Freeport Coals of Northern West Virginia. In: Proceedings, 1984 Mining and Reclamation Conference. West Virginia University, Morgantown, W.V.

Renton, J.J. and R.V Hidalgo. 1975. Some geochemical considerations of coal. Coal Geology Bulletin (4). West Virginia Geological and Economical Survey. Morgantown, WV.

Rich, D.H., and K.R. Hutchinson. 1990. Neutralization and stabilization of combined refuse using lime kiln dust at High Power Mountain. In: Proceedings, 1990 Mining and Reclamation Conference, April 21-24, 1990. West Virginia University. Morgantown, WV.

Richardson, A.R. and M.T. Doughterty. 1976. Feasibility study of Deer Creek daylighting project, Environmental Protection Technical Series, USEPA, EPA-600/2-76-110.

Robb, G. and J. Robinson. 1995. Acid drainage from mines. The Geographical Journal. 161: $47-54$.

Rose, A.W., L.B. Phelps, R.R. Parizek, and D.R. Evans. 1995. Effectiveness of lime kiln flue dust in preventing acid mine drainage at the Kauffman surface coal mine, Clearfield County, Pennsylvania. pp. 159-171. In: Proceedings, 1995 National Meeting of the American Society for Surface Mining and Reclamation June 3-8, 1995, Gillette, WY.

Skousen, J., K. Politan, T. Hilton, and A. Meek. 1990. Acid mine drainage treatment systems: chemicals and costs. Green Lands 20(4): 31-37.

Skousen, J., and P. Ziemkiewicz. 1996. Acid mine drainage control and treatment. National Research Center for Coal and Energy, West Virginia University, Morgantown, WV. 
Skousen, J., A. Sexstone, and P. Ziemkiewicz. 2000. Acid mine drainage control and treatment. pp. 131-168 In: Reclamation of drastically disturbed lands. Ed. Barnhisel, R. R. Darmody, and W. Daniels. American Society of Agronomy, Madison, WI.

Skousen, J., J. Simmons, L.M. McDonald, and P. Ziemkiewicz. 2002. Acid-base accounting to predict post-mining drainage quality on surface mines. J. Environ. Qual. 31: 2034-2044.

U.S. Environmental Protection Agency. 1995. Streams with Fisheries Impacted by Acid Mine Drainage in MD, OH, PA, VA, and WV. Region III, Wheeling, WV.

USDA, Soil Conservation Service. 1976. The measure of our land. USDA. Soil Concerv. Serv. PA-128. \#M3254.

Wendland, W.M. 2001. Temporal responses of surface water and groundwater to precipitation in Illinois. J. American Water Resources Associations. 37: 685-693.

Wood, S.C., P.L. Younger, and N.S. Robins. 1999. Longterm changes in the quality of polluted minewater discharges from abandoned underground coal workings in Scotland. Quarterly J. Engineering Geology 32: 69-79.

Younger, P.L. 1994. Minewater pollution: The revenge of Old King Coal. Geoscientist 4(5): 48-41.

Younger, P.L. 1997. The longevity of minewater pollution: a basis for decision-making. Science of the Total Environment 194/195: 457-466.

Younger, P.L., T.P. Curtis, A.P. Jarvis, and R. Pennell. 1997. Effective passive treatment of aluminum-rich, acidic colliery spoil drainage using a composted wetland at Quaking Houses. County Durham. J. Institution of Water and Environmental Management 11: 200-208.

Zeleznik, J, and J. Skousen. 1996. Survival of three tree species on old reclaimed surface mines in Ohio. J. Environ. Qual. 25(6): 1429-1435.

Ziemkiewicz, P.F. and J.G. Skousen. 1992. Prevention of acid mine drainage by alkaline addition. Green Lands 22(2): 42-51. 


\section{CHAPTER 3: LONGEVITY OF ACID DISCHARGES FROM UNDERGROUND MINES LYING ABOVE THE REGIONAL WATER TABLE}

\section{$\underline{\text { Introduction }}$}

Surface mining has disturbed approximately 1.8 million ha (4.4 million ac) in the Appalachian Region since 1930 (Barnhisel et al. 2000, Paone et al. 1978, Zeleznik and Skousen 1996). No estimates have been made on the areal extent of underground mining in this region. The West Virginia Department of Environmental Protection (WVDEP) estimates that in West Virginia alone about 610,000 ha (1.5 million ac) have been mined by underground methods, while about 276,000 ha $(682,000 \mathrm{ac})$ have been surface mined in the state (Bennett, 2003). Therefore, extensive underground areas have been disturbed in this region, thereby influencing water supplies and water quality.

Acid mine drainage (AMD) is a serious problem in areas of extensive surface and underground coal mining, such as the Appalachian Region of the U.S, where pyrite and other metal sulfides are found within the coal and associated rocks. About 10,000 km of streams have been affected by AMD in the four states of Pennsylvania, Maryland, Ohio, and West Virginia (U.S. Environmental Protection Agency 1995). Many mines currently discharging AMD were operated and abandoned before enactment of the Surface Mining Control and Reclamation Act (SMCRA) of 1977. The Act provided standards for environmental protection during mining operations and placed the responsibility of AMD control and treatment on the operator (SMCRA 1977). The SMCRA also provided a means for reclaiming abandoned mines by taxing current coal operators, which generates funds for abandoned mine land reclamation programs. Even with millions of dollars spent in reclaiming abandoned mine lands, these abandoned mines still generate more than $90 \%$ of the AMD in streams and rivers in the region and most of this acidic drainage flows from underground mines (Faulkner 1997, Zipper 2000).

Because these sites were abandoned before 1977, no company or individual is responsible to treat the water, and therefore the receiving streams are continuously polluted and severely impact the aquatic ecosystem. High flows and high levels of pollution (high acidity and metal concentrations) require the use of chemicals for treatment, which tend to be expensive and labor 
intensive (Skousen et al. 2000). Costs for chemicals, dispensing equipment, electricity for pumps, and manpower all add up to significant public expense if the treatment entity is a government agency or utility. Perhaps the largest cost to the public is the unavailability of the water resource for use, and its accompanying impaired aesthetics and degradation. Therefore, simple and inexpensive treatment approaches (such as passive treatment systems, Skousen et al. 1998) are being sought as well as a better understanding of the natural processes within mines that affect water quality over time.

An understanding of the behavior of acid-producing materials within abandoned mines would allow an estimate of the longevity of the acid discharge, which will aid in determining remediation strategies and the short and long-term costs of treatment. However, the changes in flow and water quality over time from surface and underground mines are not well documented.

Surface mining generally removes $90 \%$ or more of the coal (which often contains the highest sulfide content and hence the acid-producing potential) thereby leaving little in the backfill for continued reaction and acid generation. Pyrite is often dispersed among other rocks above and below the coal seam. The pyrite-bearing rocks and coal left behind were broken apart by blasting giving high surface area, and the acid products are leached fairly rapidly, typically within 10 to 20 years (Meek 1996). Carbonate rocks within the overburden may neutralize some or all of the AMD generated during surface mining. Special handling of toxic materials may reduce the amount of pyrite oxidized, and the addition of alkaline material during mining may neutralize acid in-situ, both of which decrease the total acid load coming from the site (Brady et al. 1990, Perry and Brady 1995, Rich and Hutchinson 1990, Rose et al. 1995, Skousen and Larew 1994). During the ensuing 20 years after reclamation, discharge water quality may reach pre-mining levels. Overburden analytical techniques such as Acid-Base Accounting help predict the overall potential for AMD during surface mining and reclamation, and can help regulators determine when surface mining should or should not be allowed (Skousen et al. 2002).

Acid discharge from underground mines usually lasts much longer than from surface mines (Wood et al. 1999). For underground mine discharges, a distinction is made between those that become inundated or flooded with water (the mined coal seam is located below the regional water table and called "below-drainage" underground mines) and those that do not fill with water because they are situated above creeks and rivers of the area (the coal seam is located above the regional water table and called "above-drainage")(Figure 3-1). This distinction is critical 
because acid-producing materials composed of pyrite react at much slower rates and produce only small amounts of AMD when left in an anaerobic condition underground (Evangelou 1995, Fennemore et al. 1998). Therefore, flooded below-drainage underground mines tend to have a finite life for discharging AMD because oxygen depletion limits acid generation.

The earliest model of longevity of AMD discharge from underground mines was the former British Coal Corporation's 'rule of thumb' for fully-flooded below-drainage mines. Iron concentrations in an abandoned mine were assumed to decrease by $50 \%$ during each subsequent pore volume flushing (the time period required for the mine pool to "turnover" or in other words to recharge and discharge that volume of water). For example, if 10 years are required for the water within an underground mine to turnover, the iron concentration should decrease by half every 10 years. This suggests an exponential decay as described by Glover (1983). Therefore, about three turnover cycles (or 30 years in this case) are necessary for the iron concentration to decline to about $12.5 \%$ of the original iron concentration if this rule is accurate. Younger et al. (2002) refer to this as the "first flush," where the acid products are washed out based on the mine's hydrology. However, they state that the duration of flushing manifests a much more complex hydraulic process based on the tortuosity and heterogeneous permeability of the old mine workings.

Other researchers have observed that the most severe drainage occurs within the first few decades after closure and even the largest underground mine systems settle to lower pollution levels within 40 years. For mines in the UK, a neutral $\mathrm{pH}$ was reached within 30 years, and after 40 years the $\mathrm{pH}$ remained neutral and the iron concentrations decreased from $200 \mathrm{mg} / \mathrm{L}$ to $<40$ $\mathrm{mg} / \mathrm{L}$ (Wood et al. 1999). Younger (2000) found that flooded underground mines in the UK stabilized at pH 7 with gradually decreasing iron concentrations. Jones et al. (1994) also showed that water from flooded underground mines in Pennsylvania changed from acidic to neutral over a period of decades.

Lambert and Dzombak (2000) located three underground discharges in the Uniontown Syncline of Pennsylvania with distinct flooding histories. This study used underground mines in the Pittsburgh coal seam, one of the coal seams we sampled in our study. Water quality measurements had been taken in 1974 and 1999 in each mine. A flooded below-drainage mine closed in 1934 (40 and 65 yrs had passed since closure) had a pH of 6.0 in 1974 and 6.4 in 1999, Fe decreased from 45 to $25 \mathrm{mg} / \mathrm{L}$, and sulfate was $1700 \mathrm{mg} / \mathrm{L}$ in 1974 and 1000 in 1999 (net 
alkaline water). In a flooded below-drainage mine that was closed in 1970 (instead of 1934), pH increased from 3.1 in 1974 to 5.9 in 1999 , Fe decreased from $140 \mathrm{mg} / \mathrm{L}$ to $70 \mathrm{mg} / \mathrm{L}$, while sulfate decreased from $2000 \mathrm{mg} / \mathrm{L}$ to $900 \mathrm{mg} / \mathrm{L}$ in 1999 (changed from strongly acidic water to slightly acidic water). Therefore, the researchers concluded that underground mine water quality changed from acidic to alkaline within 30 years after closure and flooding in their geologic setting. Water pH from an unflooded above-drainage mine closed in 1934 was 3.0 in 1974 and 3.5 in 1999, while Fe decreased from $10 \mathrm{mg} / \mathrm{L}$ in 1974 to <2 in 1999 and sulfate declined from $800 \mathrm{mg} / \mathrm{L}$ in 1974 to $600 \mathrm{mg} / \mathrm{L}$ in 1999. Water in all cases was net acidic from the unflooded mine. Therefore, unflooded above-drainage areas improved in drainage quality, but still remained net acidic (albeit with low metal concentrations) 60 years after closure. Other researchers have found similar results in this region (Brady et al. 1998, Capo et al. 2001).

Donovan et al. (2000) monitored the water quality of a large underground mine pool in a setting similar as that of Lambert and Dzombak (2000). The Montour mine, a Pittsburgh coal seam underground mine in PA, had a section flooded in 1970 and also a section flooded in 1982. Water conditions in the connected mine pool were strongly acidic ( $\mathrm{pH} \sim 3.0$, acidity $2200 \mathrm{mg} / \mathrm{L}$ ) for the first two years after the final flooding in 1982, after which acidity began to decline exponentially. Surprisingly, seven years after flooding (five years after peak acidity concentrations), the water in the mine pool became net alkaline and has stabilized at a $\mathrm{pH}$ of 6.4 , net alkalinity at $200 \mathrm{mg} / \mathrm{L}$, and iron around $60 \mathrm{mg} / \mathrm{L}$. The good quality water in the 1970 flooded mine probably caused a more rapid neutralization of the water in the 1982 flooded mine.

Younger (1997) divided the acid load flowing from underground mines into two categories. "Vestigial" acidity is associated with the first-time flushing of acid products from the mine during initial abandonment and flooding. "Juvenile" acidity is produced from ongoing pyrite oxidation due to fluctuations in the water table. Juvenile acidity, he states, can persist for hundreds of years depending on the pyrite content and hydrology of the underground mine system. The longevity of AMD at a given site is dependent on the rate of depletion of both the vestigial and juvenile acidity.

In above-drainage underground mines, the mine voids and acid-generating materials are continually exposed to seasonal high and low water levels in the mine or mostly unflooded conditions throughout the year, and tend to be recharged rapidly by infiltrating rain and snowmelt. Furthermore, the water moving into the mine voids can be discharged just as rapidly 
out of the mine depending on its connectivity with surface portals or seeps. The mine atmosphere contains sufficient oxygen to sustain pyrite oxidation because the mine atmosphere interacts with the outside atmosphere via fractures and unsealed openings, especially in response to changes in atmospheric pressure (i.e., they breathe). Therefore, oxygen and water are not limiting factors for continuing pyrite oxidation and transport of reaction products. Indeed, these quick recharge/discharge and breathing conditions are ideal for acid generation and pyrite reaction continues until the pyrite supply either becomes fouled by acid product coating (armoring) or becomes exhausted. Under these optimized oxidizing and flushing situations, it is possible that discharges could be contaminated for decades or centuries depending on the pyrite supply and flushing events.

In above-drainage mines, water usually discharges out at the down-dip side of the mine at the portal or at other low elevation areas in the mine through thin coal barriers or fractures. Regardless of the discharge point, the mine water continually flows out without fully flooding the mine and acid-generation may continue for decades until the pyrite is either exhausted or coated, which limits surface area for reaction (Lambert and Dzombak 2000, Younger et al. 1997). In these situations, the rate of water quality improvement over time (or acidity decline) is highest where the recharge rate of the mine is high, water flow out of the mine is high, residence time is low, and the mine volume is small (Younger 1997). The fluctuating water level and pooling effect due to seasonal variations in precipitation, however, aid acid generation. During low water levels, pyrite oxidation forms iron hydroxysulfate solids, which precipitate on coal and rock surfaces due to evaporation. Hydrated ferrous and ferric sulfate minerals such as melanterite, rozenite, copiapite, and jarosite have all been identified as precipitated minerals in coal mines (Nordstrom 1982, Younger 2000), and all of these minerals provide short-term storage of metals, acidity and sulfate that are soluble. When the water level rises, these acid products are dissolved, released into the mine pool, and flushed out of the mine during seasonal recharge times. Pyrite oxidation can continue to occur on the wet, oxidized mineral surfaces, producing an optimized and continuing cycle of acid generation (Younger 1997). Therefore, these above-drainage underground mines generally will discharge poor water quality for much longer periods than flooded mines because more of the pyrite is continuously exposed to a mixture of air and water to form acid products, and released. 
Much discussion has occurred on the seasonal changes in water quality from above-drainage underground mines, including changes in $\mathrm{pH}$, acidity, and metal concentrations. Pigati and Lopez (1999) reported that the observed seasonal variations in water chemistry from the abovedrainage 126-ha Majestic Mine in OH supported the "spring flush" hypothesis (Johnson and Thornton 1987). Acidity and metals generated and deposited on surfaces during summer and fall (seasonal dry months in this region) were largely flushed with late winter-early spring snowmelt and rainfall. Therefore during the high recharge and discharge season of February to May, the high water flows carried high concentrations of acidity and metals. This is opposed to the "high concentration at low flow" hypothesis, where the worst drainage from underground mines happens at base flow conditions (dry months) where acid and metals are thought to be concentrated and not diluted by surface water during recharge events (Skousen and Ziemkiewicz 1996).

The Omega Mine, a 68-ha above-drainage underground mine in the 1.4-m thick Upper Freeport coal seam in northern WV, was mined during the 1980s. In 1992, breakout of AMD caused mine closure, and flows and acidity concentrations were recorded continuously for the ensuing six years (GAI Consultants 2001). From 1993-1999, average year-round water flow was $1.4 \mathrm{~L} / \mathrm{s}(22.6 \mathrm{gpm})$ and acidity was $4,847 \mathrm{mg} / \mathrm{L}$. Water flow from the mine averaged $2.7 \mathrm{~L} / \mathrm{s}(43$ gpm) during February to May (1993-1998), and only 1.1 L/s (18 gpm) during June to January (1993-1998). Acidity was highest during February to May ( 4,500 mg/L) compared to about 3,800 $\mathrm{mg} / \mathrm{L}$ during June to January. Above-drainage mines, based on these and other examples, appear to discharge their worst acid and metal concentrations during high flow seasons (spring flush), with improved water quality during dry periods.

It is clear that discharge chemistry from underground mines is affected by several factors, and efforts to determine the changes in water quality over time require accounting for these factors. First, the season of sampling is important to consider, with two distinct periods being documented in our region: February to May and June to September. Flows in October, November, December and January from underground mines are especially hard to predict because these months alternate between very high flows like those of February to May and very low flows like those from June to September (GAI Consultants 2001, Pigati and Lopez 1999).

Another important factor in mine water chemistry is the coal seam, and more specifically the pyrite content of the mined coal (Younger 2000). Each coal seam is unique with relatively 
predictable chemical and physical features, which affects the magnitude of the discharge water quality.

The mining method and degree of coal removal within a mine are other variables affecting discharge chemistry. Room and pillar underground mining (the most common method in this area) left about 50\% of the coal as support for the roof (Reece et al. 1978). After abandonment, this coal continues to weather and crack from the pillar and oftentimes the pillar completely collapses, allowing more pyrite in the coal pillar and overlying rocks that have dropped into the void to react. In "retreat" mining, many of the coal pillars left to support the roof are removed as the mining equipment is withdrawn, allowing more roof rock to subside into the mine voids. The coal pavement or floor rock also can contribute pyrite surfaces for reaction, depending on its flooded condition and slope. Remining underground mines by surface mining has the potential to improve pre-existing acid discharges by removing coal pillars and then reclaiming the site to current reclamation standards, which often includes mitigating any AMD potential (Hawkins 1994, Richardson and Doughterty 1976).

Acid discharges from abandoned mine sites can be affected by subsequent, adjacent surface mining (Skousen et al. 1997) or other nearby surface disturbances. The flow may decrease because the surface overlying the recharge area has been reclaimed and vegetated, thereby decreasing infiltration into the underground mine, or surface fractures or subsidence holes may have been repaired and closed off. Any of these surface disturbances could effectively decrease the flow rate into and therefore out of the mine. Adjacent surface mining and blasting may also cause collapse of the roof in portions of the mine and reduce the void space, thereby changing flow paths or altering interconnection of certain areas. The degree of disturbance in a mine is nearly impossible to measure (down hole cameras have been used to look into underground mines, but they allow only a small peek into the void space) and only observable surface disturbances overlying or adjacent to the underground mine provide evidence that such disturbance effects exist. Even so, the ensuing impact of surface disturbances on mine water chemistry is difficult to predict over time.

A research project was initiated in 1968 which identified and sampled over 150 underground mine discharges in the northern West Virginia coal region. Most of these discharges were coming from unflooded above-drainage underground mines in the Upper Freeport and Pittsburgh coal seams. We revisited many of those sites in 1999 and 2000 and collected and analyzed the 
water from about 75 of the same discharge points. Based on the completeness of the 1968 data, 44 were chosen for further analysis. Twenty of these 44 sites had been sampled and the water analyzed in 1980, which provided an intermediate sampling time to assess water acidity and iron concentrations from the mine. From this data set, our objective was to determine the changes in water quality during this 30 -year period.

\section{Materials and Methods}

From the original 75 sites sampled in 1999-2000, 44 underground mine discharge sites were used for water quality comparison because all parameters used for the analysis were available for both 1968 and 1999-2000 data sets. The sites were located in Preston and Monongalia Counties of West Virginia. The sites were found according to marked locations on Valley Point, Cuzzart, Kingwood, Masontown, and Morgantown North U.S. Geological Survey quadrangle maps. All sites discharged water from above-drainage, underground mines into various streams within the Monongahela River Basin. All mines removed coal from either the Upper Freeport or Pittsburgh coal seams.

The Pittsburgh coal seam is the lowest stratum of the Monongahela Group in the Pennsylvanian System. The seam has 1.5 to $2 \%$ sulfur, and an ash content of $6 \%$. The Pittsburgh coal is composed of alternate layers of coal and black shale. A typical Pittsburgh coal crosssection shows a 1-m layer of pure coal, a 0.7-m layer of bone coal or slate, and another 2-m layer of good-quality coal. The Pittsburgh coal along the Monongahela and Cheat Rivers is located close to the surface, and can be mined by surface mining methods or shallow underground mines (Hennen and Reger 1914). In this region, few overlying limestone materials are available within $30 \mathrm{~m}$ above the coal seam to neutralize the high amounts of acid-producing material in this coal and associated rocks.

The Upper Freeport coal seam is the topmost stratum of the Allegheny Formation in the Pennsylvanian System. Upper Freeport coal contains $<1.5 \%$ sulfur, and an ash content from 8 to $12 \%$. It is a multiple-bedded seam that is divided into a top coal and bottom coal, separated by a shale interlayer, all averaging a total of $2 \mathrm{~m}$ in thickness (Hennen and Reger 1914). The strata above the Upper Freeport coal contain several massive sandstones and some shales. Limestone or alkaline-bearing rock units are not generally found within $50 \mathrm{~m}$ above the Upper Freeport coal 
in this area, so very little overlying geologic material is available for acid neutralization (Hennen and Reger 1914).

\section{Study}

A previous research project was conducted during the summers of 1968-1970 (June to September) where field crews were sent out to identify all coal mines within the Monongahela River Basin and to sample their discharges. Each crew worked from 7.5-minute U.S. Geological Survey topographic maps on which they outlined mine boundaries and indicated mine openings. Field sheets were also completed at each site with location and overburden information. Sites with a discharge were identified on the maps, flow rates were determined, and the water was sampled. The flow rate was measured when possible with a bucket and stopwatch. For larger flows, the crew installed a V-notch weir and measured flow rate. These values were recorded on the field sheet. In the field at the time of water collection, the $\mathrm{pH}$ of the discharge was measured using an electrometric $\mathrm{pH}$ meter, and temperature was checked with a lab grade thermometer. These values were recorded on the field sheet.

Two water samples were taken at each discharge in this early study: 1) a plastic, 1-L bottle was filled with water, put on ice, and then analyzed in the laboratory for acidity, alkalinity, conductivity, sulfate, and $\mathrm{pH}$; and 2) a 50-ml glass bottle was filled, treated with acid, and then analyzed in the laboratory for metals (total iron, manganese, aluminum). Water samples were delivered to the laboratory each Friday where they were analyzed using methodology from the latest edition of Standard Methods (American Public Health Association 1965). Water analyses were monitored for accuracy and precision by running periodic samples of reference standards (Bryant 1999).

\section{9-2000 Study}

After obtaining the 1968 maps, we located the point discharges marked by the 1968 crew on the topographic maps during the summers of 1999 and 2000 (June to September) and correlated these to underground mine maps and areas (Table 3-1). Underground mine maps were obtained from the West Virginia Geologic and Economic Survey in Morgantown, West Virginia, underground mine boundaries were determined, and mine size was determined with a digital planimeter (Sokkia Corp., Overland Park, KS). The year in which each mine was opened was also determined from records of the West Virginia Office of Miners Health Safety and Training. 
Each site in 1999-2000 was categorized as disturbed or undisturbed. Undisturbed meant that the land surface around the underground mine site appeared to have remained untouched since 1968 and no obvious influence had occurred to the surface overlying or nearby to the underground mine. Disturbed suggested that either surface mining had occurred overlying or adjacent to the underground mine since 1968 or was reclaimed or remined.

Discharges were sampled as close to the mine portal as possible. Flows were calculated using a measured cross-sectional area and flow velocity. Two water samples were taken at each sample point: 1) a 250-mL unfiltered sample was taken for general water chemistry $(\mathrm{pH}$, conductivity, total acidity and alkalinity by titration, and sulfate); and 2) a 25-mL, filtered sample was acidified to $\mathrm{pH}<2$ with $0.5 \mathrm{~mL}$ concentrated nitric acid and used to determine metal concentrations.

Water $\mathrm{pH}$, alkalinity, and acidity were determined by a Metrohm $\mathrm{pH}$ Stat Titrino System (Brinkman Instruments, Wesbury, NY). Conductivity was measured using an Orion Conductivity meter Model 115 (Orion Instruments, Beverly, MA). The metal analysis was preformed using an Inductively Coupled Spectrophotometer, Plasma 400 (Perkin Elmer, Norwalk, CT). Sulfate was measured turbidimetrically by flow injection analysis (Latchat Instruments, Milwaukee, WI).

The West Virginia Division of Water Resources also conducted periodic sampling and analyses of underground mine discharges in this area (West Virginia Division of Natural Resources 1985). We accessed their data and found that 20 of their sample sites matched our discharges sampled in 1968 and 1999-2000. Therefore, we used their water quality analyses as an intermediate data point between 1968 and 1999 to aid in estimating the rate of change (improvement) in water quality.

\section{Statistical Analysis}

A repeated measures analysis of variance was performed to test for changes in discharge water quality over time. We used a full model with the main effects of date, coal seam, disturbance, and all possible interactions as class variables using PROC GLM (SAS Institute 1989). For the comparison between 1968 and 1999-2000, coal seam (Pittsburgh and Upper Freeport) and disturbance (yes or no) were the between-subjects variables. For comparisons between 1968, 1980, and 1999-2000, there were not enough degrees of freedom to make 
meaningful comparisons with disturbance as a model term. Therefore for the analysis of three dates, coal seam was the only between-subjects variable. The Greenhouse-Geiser criterion was used for parameters that did not meet the sphericity condition as determined using Mauchley's test (Huck and Cormier 1996). Since our principal interest was the time dependent changes in discharge water quality, the assumption of homogeneity of variance was not tested in the between-subjects variables, and between-subjects comparison are neither provided, nor interpreted. For all statistical analyses, samples collected in 1999 were coded as if they were collected in 2000. Trends in discharge water quality improvements were plotted for the 1968, 1980, and 1999-2000 data.

To assess the potential effects of flow on discharge water chemistry and to determine the amount of variability within a sampling season, we gathered historical data from two discharges of above-drainage underground mines in this region with more frequent within-year sampling and examined seasonal changes in flow and concentrations. The Omega above-drainage underground mine is a 70-ha mine and is located in an adjacent watershed from most of our underground mines, but drains the same Upper Freeport coal seam as many of the discharges in this study. Six years of data (1993-1998) were available from this site (GAI Consultants 2001). The T\&T above-drainage underground mine drains an area of about 600 ha and is located in the same watershed and in the same Upper Freeport coal seam as most of the underground mine discharges used in this study. Seven years (1994-2000) of data were available from this discharge. Analysis of variance with year and month as categorical variables was used to test for a relationship between flow and discharge water quality using 12-month versus four-month (June to September) data.

\section{Results and Discussion}

\section{Flow and Concentration Differences within a Year}

Analysis of the Omega data (GAI Consultants 2001) for 1993-1998 showed a significant difference in water flow between the months of February to May (2.7 L/s or $43 \mathrm{gpm})$ and June to September (1.3 L/s or $20 \mathrm{gpm}$ ) (analysis not shown). Acidity was highest at Omega during February to May (90 $\mathrm{mmol} \mathrm{H}^{+} \mathrm{L}^{-1}$ ) compared to $75 \mathrm{mmol} \mathrm{H}^{+} \mathrm{L}^{-1}$ during June to September, but the difference was not significant. There was a 52\% decrease in flow between high vs. low flow months, but only an $18 \%$ decrease in acidity. From T\&T during 1994-2000, there was a 
tendency for iron and acidity concentrations, and flow to decrease, and for $\mathrm{pH}$ to increase (Figure 3-2). A significant monthly effect was found for all water quality parameters when measured over 12 months (Table 3-2), but the only parameter for which there was a clear seasonal trend was flow (Figure 3-2). Maximum flows occurred in spring in this region as a consequence of snowmelt and higher rainfall (Pigati and Lopez 1999, Stewart and Skousen 2003). Although flow was positively correlated with acidity and iron for 12 months and for June to September, the correlation coefficients were small (Table 3-3). Therefore, we conclude that, except for flow, samples collected from June through September give comparable water quality data and that, within this period, differences in flow do not bias water quality.

Water quality variability within a year at T\&T was fairly high (Table 3-4), with annual relative standard deviations of up to $44 \%$ for flow, $30 \%$ for acidity, and $32 \%$ for iron. When just the months of June to September were considered, average RSDs were always lower (e.g., 29 versus $44 \%$ for flow) than the 12-month period (Table 3-4). Of interest in this study was the magnitude of the relative difference between the minimum and maximum values $(\% \Delta)$ as this gives a basis for comparing changes in water quality over time. The $\% \Delta$ for each parameter was always larger than the RSD (Table 3-4). Percent differences more negative than the four-month $\% \Delta$ was used as an estimate of a conservative criterion for demonstrated improvement in water quality on our 44 discharge sites.

\section{Comparisons between 1968 and 2000}

The average flow from above-drainage underground mines in 1999-2000 was $0.5 \mathrm{~L} / \mathrm{s}$, which was substantially less than the $1.4 \mathrm{~L} / \mathrm{s}$ in 1968 (both were sampled during the June-September period) (Table 3-5). However, these differences were not statistically significant, either as a main effect $(\mathrm{p}=0.07)$ or as an interaction with coal seam $(\mathrm{p}=0.72)$. Based on this result and on the data analyses presented in the preceding section, flow was assumed to have a small or negligible effect on discharge water quality and water quality data were compared directly.

There were no significant changes in $\mathrm{pH}(\mathrm{p}=0.06$ between dates; $\mathrm{p}=0.06$ for interaction date*coal seam) between 1968 and 1999-2000. The average $\mathrm{pH}$ for all years and all coal seams was 3.2. However, Pittsburgh coal mine discharge sites had a significantly lower $\mathrm{pH}$ in 19992000 than Upper Freeport coal mine discharge sites (Table 3-5). 
For all other parameters, there were significant improvements between 1968 and 1999-2000 $(\mathrm{p}=<0.001)$, with average improvements of $66 \%$ for total acidity and $79 \%$ for iron (Table 3-5). The date*coal seam interactions were due to significant differences between coal seams in 1968 and a lack of differences in 1999-2000, except for $\mathrm{pH}$ in 1999-2000 (Table 3-5). Average decreases in Pittsburgh coal seam iron (85\%) and total acidity (79\%) were larger than the decreases in Upper Freeport coal seam iron (74\%) and total acidity (56\%). This is probably due to the higher sulfur content of the Pittsburgh coal seam and possibly to the higher amount of shale associated with the seam compared to Upper Freeport coal. The shales weathered quickly releasing the acid products resulting in high initial acidity, iron and sulfate concentrations that descended gradually over time. Upper Freeport coal had more sandstone, which reacted and released acid products more slowly than the shales.

Even though significant improvements in average iron and acidity concentrations were found, not every site showed improved water quality. Figure 3-3 is a cumulative frequency plot for the percent change in acidity and iron. All Pittsburgh sites showed some improvement (\% change was $<0$ ), while one Upper Freeport site showed an increase in iron and five Upper Freeport sites showed increases in acidity. Using zero percent change $(\% \Delta)$ as the criterion for improvement is probably too liberal as it ignores the potential variability within a year that could bias the conclusions. Using a more conservative criterion for demonstrated improvement (-38.8 for acidity and -59.2 for iron, Table 3-2), 10 of 35 Upper Freeport sites did not improve in acidity and 11 of 35 sites failed to show improvement for iron. One Pittsburgh site also failed to show an improvement in iron.

\section{Comparisons among 1968, 1980, and 1999-2000}

When comparing the data across three dates (Table 3-6), there were no significant differences for flow among dates $(\mathrm{p}=0.20)$ or coal seams $(\mathrm{p}=0.82)$. Therefore, as in the two-date analysis, water quality data were compared directly.

There was a significant effect of date for $\mathrm{pH}$ when comparing the three dates $(\mathrm{p}=0.0002)$, but no difference between coal seams ( $\mathrm{p}=0.39)$. The date effect is a consequence of the lower $\mathrm{pH}$ measured in 1980 compared to either 1968 or 1999-2000 (Table 3-6). There was a significant effect of date for both acidity and iron $(\mathrm{p}=<0.001)$, and differences due to coal seam for acidity 
$(\mathrm{p}=<0.001)$ and iron $(\mathrm{p}=<0.01)$. The trends were for a curvilinear decrease in acidity $(\mathrm{p}=0.015)$ and a linear decrease in iron $(\mathrm{p}=<0.01)$ (Table 3-6).

Despite these overall trends, not all sites behaved similarly. When each site was plotted individually, all five Pittsburgh coal seam discharges showed some improvement in total acidity and iron (Figure 3-4). For acidity, all but one (Lake Lynn 1) showed an apparent curvilinear trend with time. For iron, only Cheat River 4 and Cheat River 5 showed this curvilinear trend (Figure 3-4). For the 10 Upper Freeport discharges (out of 15) that showed improvements in acidity, most of those trends (eight out of 10) were apparently linear (Figure 3-5). For the Upper Freeport sites that did not show improvement in acidity, three of the five had an increasing linear trend with time. For the other two sites, acidity in 1980 was lower than in either 1968 or 19992000 (Figure 3-5). For Upper Freeport sites with a decrease in iron concentration, only four of 11 showed an apparent curvilinear trend (Figure 3-6). In Upper Freeport sites that did not show improvement in iron, most were because the 1980 iron concentrations were the lowest.

\section{Effects of Disturbance, Mine Size, and Time Since Closure}

Disturbance did not have a significant effect on acidity concentrations $(\mathrm{p}=0.43)$, which suggests that reclamation at the portal face or at the surface overlying these underground mines did not change flow paths or amounts of water moving through the underground mine to sufficiently change concentrations over time.

We evaluated the effect of mine size on acidity and found no relationship in our discharge data $(\mathrm{p}=0.38)$. While this result seems counter-intuitive, there are some reasons that may account for this finding. Several of the discharges in our study were found to be coming from the same underground mine (based on old underground mine map locations). Examples of this are the Glade Run 4 and 5 discharges, and the Bull Run 1 and 2 discharges in Table 3-1. One would assume that discharges coming from the same underground mine (even though one discharge might be located around the hillside or in the next valley from the other) would be similar in quality. However, some of the discharges coming from the same mine were very different in quality, which resulted in poor correlations between mine size and acidity. Stratification has been noted from underground mine pools (Ladwig et al. 1984), but this stratification has been measured in flooded underground mines with long residence times. One certainly would not expect large differences in discharge quality from shallow, unflooded above- 
drainage underground mines, which are generally flushed within days of rain events. If large differences were found, then the residence time of the water in the underground mine was substantially increased, there may have been stagnant pools of water in the mine formed by roof caving or pillar collapse, the coal seam characteristics (pyrite or shale content) were drastically changed over a short distance to cause an increase in acidity concentrations, or the water drainage from the mine came from a different section of the mine. A hydrologic situation where residence times could increase may be with an undulating coal seam, where the coal seam dips and rises causing the creation of many small cells or pools of water. This effectively creates pockets of high acid water that may be discharged only during and after rainfall events. Other reasons for mine water variability within one mine is oxygen availability in distinct sections of the mine which can vary dramatically with short distances, and the order of water contact with rocks in the mine (Younger 2003).

We found no relationship $(\mathrm{p}=0.31)$ between the date the mine was opened and acidity. While a relationship would be expected to exist between time since mine closure (not mine opening date) and discharge quality, we were unable to accurately assess this relationship for a couple of reasons. The historical records were too sketchy to determine when all the mines ceased operation. We were able to find the opening date of all the mines because certificates and permits were required, but such paperwork was not necessary for closure. Therefore, even if a mine opened in 1945, the coal may have been mined for only a few years or for more than 30 years. Mine size could help indicate the length of operation, but some mines worked slowly with few men and machines, while other mines operated quickly. So the closure date could have been 1950 or 1975 , and one would predict the drainage quality to be better from a mine that was closed 50 years ago compared to one closed 25 years ago. Sometimes mines ceased operation during bad market or labor conditions, then reopened when conditions changed, or sections of the mine may have been closed off early in the life of the mine. All of these influences could confound the effect of mine opening or closure on discharge water quality.

While predictions for annual acidity declines or decay rates have not been made here, such as those made by Ziemkiewicz (1994), Younger (2000), and Demchak et al. (2001), these predictions have proved helpful in determining remediation strategies and costs. For example, given the scenario that the first 15 to 20 years after closure will likely produce the highest acidity levels (as was found here), suitable chemical treatment systems can be installed to treat the low 
$\mathrm{pH}$, metal-laden water. Intermediate levels of acidity are likely to be released during the next 10 to 20 years, resulting in lower chemical costs and management. Accordingly, 30 to 40 years after closure, acidity levels from these above-drainage underground mines tend to be much lower than initial concentrations and may be treated by low-cost passive systems.

Efforts must continue to determine water quality improvements from underground mines in other coal seams, and to better determine the effects of mine size and time since mine closure. The remediation strategies and cost predictions are based on our data as well as other research where water quality appears to improve within 40 years after closure. Our data suggest that the water quality improvement predictions of Younger (1997) and Glover (1983) do not fit all the above-drainage underground mines we sampled, but certainly are appropriate for the flooded below-drainage mines they encountered in the UK and also those in the eastern US.

There is still much work to be done on mine drainage improvement over time. It is critical to have a better understanding of the time needed for mine drainage improvement so as to plan suitable watershed restoration projects. Situations where the flow or the underground mine pool has been altered (due to sealing, grout injection or other such remediation strategy) could help us measure the effects of these factors on discharge improvement, and lessons can be learned as data sets are generated with more frequent sampling from underground mines.

\section{Conclusions}

Our data indicate that the drainage from the majority (34 of 44 sites or $77 \%$ ) of abovedrainage underground mines showed significant improvement in acidity over time, and this is good news for watersheds with numerous underground mine discharges. While significant coal seam effects were found, still a 50 to $80 \%$ reduction in acidity, iron, and sulfate was found for these mines in northern West Virginia between 1968 and 2000. Twenty mines had measurements of water quality in 1980, and five showed that much of the improvement in water chemistry occurred between 1968 and 1980, which suggests an apparent exponential rate of decline. However, 10 sites showed a more linear rate of decline, and five sites showed increased acidity over time. For those five sites with increased acidity over time, it is not clear what caused this increase. We cannot conclude that every above-drainage underground mine in this region will improve with time and, in fact, some have gotten considerably worse. Therefore, in contrast to surface mines and below-drainage underground mines, which all seem to improve 
over time and within a relatively short time frame, we cannot accurately predict water quality trends for all above-drainage underground mine sites with time.

The factors that appear to complicate our prediction capacity are the ongoing changes in the underground mine including collapse of coal pillars left in the mine to support the roof, the potential for the creation of fresh faces of pyrite that can generate more acid products, ever changing flow paths with blockages and mine pools forming at different places and at different times based on seasonal flow, and variability of oxygen and pyrite within the mine over short distances. Additionally, it appears that coal barriers or seals between mines can leak or completely break thereby allowing additional flow and acidity to be introduced to an adjacent mine. Such factors as these are very difficult to measure and account for in our prediction of mine drainage improvement.

\section{Acknowledgments}

The authors thank Gary Bryant of the U.S. Environmental Protection Agency for providing the 1968 underground mine drainage data. We also thank Mike Sheehan and Sheila Vukovich of the West Virginia Department of Environmental Protection for insight into the sampling and collection of 1980 water data.

\section{Literature Cited}

American Public Health Association. 1965. Standard Methods for the Examination of Water and Wastewater. $10^{\text {th }}$ Edition. APHA, Washington, DC.

Barnhisel, R., R. Darmody, and L. Daniels. 2000. Reclamation of Drastically Disturbed Lands. Agronomy No. 41. American Society of Agronomy, Madison, WI.

Bennett, Lyle. 2003. Personal communication. West Virginia Department of Environmental Protection, Division of Water Resources, Charleston, WV.

Brady, K.B., R.J. Hornberger, and G. Fleeger. 1998. Influence of geology on postmining water quality: northern Appalachian Basin. pp. 8-1 to 8-92. In: Coal Mine Drainage Prediction and Pollution Prevention in Pennsylvania. PA Department of Environmental Protection. Harrisburg, PA.

Brady, L., M.W. Smith, R.L. Beam, and C.A. Cravotta. 1990. Effectiveness of the use of alkaline materials at surface coal mines in preventing or abating acid mine drainage: Part 2. Mine site case studies. pp. 227-241. In: Proceedings, 1990 Mining and Reclamation Conference, April 21-24, 1990. West Virginia University, Morgantown, WV. 
Bryant, Gary. 1999. Personal communication. U.S. Environmental Protection Agency, Wheeling, WV.

Callaghan, T., G. Fleeger, S. Barnes, and A. Dalberto. 1998. Groundwater flow on the Appalachian Plateau of Pennsylvania. Chapt. 2. In: Coal Mine Drainage Prediction and Pollution Prevention in Pennsylvania. Pennsylvania Department of Environmental Protection, Harrisburg, PA.

Capo, R.C., W.R. Winters, T.J. Weaver, S.L. Stafford, R.S. Hedin, and B.W. Stewart. 2001. Hydrogeologic and geochemical evolution of deep mine discharges, Irwin Syncline, Pennsylvania. In: Proceedings of the $22^{\text {nd }}$ West Virginia Surface Mine Drainage Task Force Symposium, April 3-4, 2001, Morgantown, WV.

Demchak, J., J. Skousen, and L.M. McDonald. 2001. Water quality improvement over time and longevity of acid mine discharges from underground mines in northern West Virginia. pp. 174-182. In: Proceedings, 2001 National Meeting of the American Society for Surface Mining and Reclamation, June 3-7, 2001, Albuquerque, NM.

Donovan, J., B. Leavitt, E. Werner, E. Perry, and K. McCoy. 2000. Long-term hydrogeological and geochemical response to flooding of an abandoned below-drainage Pittsburgh coal mine. In: Proceedings of the $21^{\text {st }}$ West Virginia Surface Mine Drainage Task Force Symposium, April 4-5, 2000, Morgantown, WV.

Evangelou, V.P. 1995. Pyrite oxidation and its control. CRC Press, New York, NY.

Faulkner, B.B. 1997. AMD inventory in West Virginia. In: Proceedings of the $18^{\text {th }}$ West Virginia Surface Mine Drainage Task Force Symposium, April 15-16, 1997, Morgantown, WV.

Fennemore, G.G., W.C. Neller, and A. Davis. 1998. Modeling pyrite oxidation in arid environments. Environmental Science and Technology. 32: 2680-2687.

GAI Consultants. 2001. Omega Mine injection program: Monongalia County, West Virginia. Electric Power Research Institute, Inc. (EPRI), Allegheny Energy Supply, and the U.S. Department of Energy. Document \#1004032. USDOE. Pittsburgh, PA.

Glover, H.G. 1983. Mine water pollution-an overview of problems and control strategies in the United Kingdom, Water Science Technology. 15: 59-70.

Hawkins, J.W. 1994. Assessment of contaminant load changes caused by remining abandoned coal. pp. 20-29. In: International Land Reclamation and Mine Drainage Conference, April 1921, 1994. USDI, Bureau of Mines SP 06A-94. Pittsburgh, PA.

Hennen, R.V., and D.B. Reger. 1914. West Virginia Geological Survey, County Reports, Preston, County. U.S. Geological Survey. Morgantown, WV. 
Huck, S.W., and W.H. Cormier. 1996. Reading Statistics and Research. $2^{\text {nd }}$ Edition. Harper Collins, NY.

Johnson, C.A., and I. Thornton. 1987. Hydrological and chemical factors controlling the concentrations of $\mathrm{Fe}, \mathrm{Cu}, \mathrm{Zn}$, and $\mathrm{As}$ in a river system contaminated by acid mine drainage. Water Resources 21: 359-365.

Jones, P.M., S.M. Mulvay, and D. Fish. 1994. The role of sulfate and ionic strength on the shift from acid to alkaline mine drainage in southwest Pennsylvania. pp. 289-295 In: Proceedings of the International Land Reclamation and Mine Drainage Conference and the Third International Conference of the Abatement of Acid Mine Drainage. Vol. 2: Mine Drainage. US Bureau of Mines Special Publication. SP 06B-94.

Ladwig, K.J., P.M. Erickson, R.L.P. Kleinmann, and E.T. Posluszny. 1984. Stratification in water quality in inundated anthracite mines, eastern Pennsylvania. U.S. Bureau of Mines Report of Investigations RI 8837.Pittsburgh, PA

Lambert, D.C., and D.A. Dzombak. 2000. Evaluation of natural amelioration of acidic deep mine discharges in the Uniontown Syncline, Pennsylvania. In: Proceedings of the $21^{\text {st }}$ West Virginia Surface Mine Drainage Task Force Symposium, April 4-5, 2000. Morgantown, WV.

Meek, F.A. 1996. Evaluation of acid prevention techniques used in surface mining. Chapt. 11. In: Acid Mine Drainage Control and Treatment. National Mine Land Reclamation Center, Morgantown, WV.

Nordstrom, D.K. 1982. Aqueous pyrite oxidation and the consequent formation of secondary iron minerals. pp. 37-56. In: Acid Sulfate Weathering, Soil Science Society of American Special Publication Number 10. Madison, WI.

Paone, J., P. Struthers, and W. Johnson. 1978. Extent of disturbed lands and major reclamation problems in the United States. pp. 11-22. In: F.W. Schaller and P. Sutton (eds.), Reclamation of Drastically Disturbed Lands, American Society of Agronomy, Madison, WI.

Perry E.F., and K.B. Brady. 1995. Influence of neutralization potential on surface mine drainage quality in Pennsylvania. In: $16^{\text {th }}$ Annual Surface Mine Task Force Symposium, April 4-5, 1995. Morgantown, WV.

Pigati, E., and D. Lopez. 1999. Effect of subsidence on recharge at abandoned coal mines generating acidic drainage: the Majestic Mine, Athens County, $\mathrm{OH}$. Mine Water and the Environment 18(1): 45-66.

Reece, R.G., B.B. Dash, and P.A. Hamilton. 1978. Coal recovery from underground bituminous coal mines in the United States by mining method. Bureau of Mines Info. Cir. 8785. Pittsburgh, PA. 
Rich, D.H., and K.R. Hutchinson. 1990. Neutralization and stabilization of combined refuse using lime kiln dust at High Power Mountain. In: 1990 Mining and Reclamation Conference, April 21-24, 1990. West Virginia University. Morgantown, WV.

Richardson, A.R. and M.T. Doughterty. 1976. Feasibility study of Deer Creek daylighting project, Environmental Protection Technical Series, USEPA, EPA-600/2-76-110.

Rose, A.W., L.B. Phelps, R.R. Parizek, and D.R. Evans. 1995. Effectiveness of lime kiln flue dust in preventing acid mine drainage at the Kauffman surface coal mine, Clearfield County, Pennsylvania. pp. 159-171. In: Proceedings, 1995 National Meeting of the American Society for Surface Mining and Reclamation June 3-8, 1995, Gillette, WY.

SAS Institute. 1989. SAS. SAS Institute. Cary, NC.

Skousen, J., R. Hedin, and B. Faulkner. 1997. Water quality changes and costs of remining in Pennsylvania and West Virginia. pp. 64-73. In: Proceedings, 1997 National Meeting of the American Society for Surface Mining and Reclamation, May 10-15, Austin, TX.

Skousen, J., and G. Larew. 1994. Alkaline overburden addition to acid-producing materials to prevent acid mine drainage. pp. 375-381. In: International Land Reclamation and Mine Drainage Conference. Vol. 1. April 19-21, 1994. USDI, Bureau of Mines SP 06B-94. Pittsburgh, PA.

Skousen, J., A. Rose, G. Geidel, J. Foreman, R. Evans, W. Hellier. 1998. Handbook of technologies for avoidance and remediation of acid mine drainage. Acid Drainage Technology Initiative (ADTI) of the U.S. Office of Surface Mining. National Mine Land Reclamation Center, West Virginia University. Morgantown, WV.

Skousen, J., A. Sexstone, and P. Ziemkiewicz. 2000. Control and treatment of acid mine drainage. pp. 131-168. In: Reclamation of Drastically Disturbed Lands, Agronomy No. 41, American Society of Agronomy, Madison, WI.

Skousen, J., J. Simmons, and P. Ziemkiewicz. 2002. Acid-base accounting to predict postmining drainage quality on surface mines. J. Environ. Qual. 31(6): 2034-2044.

Skousen, J., and P. Ziemkiewicz. 1996. Acid mine drainage control and treatment. National Research Center for Coal and Energy, West Virginia University. Morgantown, WV.

Stewart, J., and J. Skousen. 2003. Water quality changes in a polluted stream over a twentyfive-year period. J. Environ. Qual. 32(2): 654-661.

Surface Mining Control and Reclamation Act. 1977. Public Law 95-87. U.S.C. 1201 et.seq.

West Virginia Department of Natural Resources. 1985. Cheat River subbasin abandoned mine drainage assessment. WV DNR, Division of Water Resources. Charleston, WV. 
Wood, S.C., P.L. Younger, and N.S. Robins. 1999. Long-term changes in the quality of polluted minewater discharges from abandoned underground coal workings in Scotland. Quarterly Journal of Engineering Geology. 32: 69-79.

Younger, P.L. 1997. The longevity of minewater pollution: a basis for decision-making. Science of the Total Environment. 194/195: 457-466.

Younger, P.L. 2000. Predicting temporal changes in total iron concentrations in groundwaters flowing from abandoned deep mines: a first approximation. J. Contaminant Hydrology. 44:47-69.

Younger, P.L. 2003. Personal communication, University of Newcastle, Newcastle, U.K.

Younger, P.L., S.A. Banwart, and R.S. Hedin. 2002. Mine Water Hydrology, Pollution, Remediation. Kluwer Academic Publishers. Boston, MA.

Younger, P.L., T.P. Curtis, A.P. Jarvis, and R. Pennell. 1997. Effective passive treatment of aluminum-rich, acidic colliery spoil drainage using a composted wetland at Quaking Houses. County Durham. Journal of the Institution of Water and Environmental Management. 11: 200-208.

U.S. Environmental Protection Agency. 1973. The status of active deep mines in the Monongahela River Basin. Region III. Wheeling, WV.

U.S. Environmental Protection Agency. 1995. Streams with Fisheries Impacted by Acid Mine Drainage in MD, OH, PA, VA, and WV. Region III, Wheeling, WV.

Zeleznik, J, and J. Skousen. 1996. Survival of three tree species on old reclaimed surface mines in Ohio. J. Environ. Qual. 25(6): 1429-1435.

Ziemkiewicz. P. 1994. AMD-TIME: A simple spreadsheet for predicting acid mine drainage. pp. 395-400. In: International Land Reclamation and Mine Drainage Conference. Vol. 1. April 19-21, 1994. USDI, Bureau of Mines SP 06B-94. Pittsburgh, PA.

Zipper, C.E. 2000. Coal mine reclamation, acid mine drainage, and the Clean Water Act. pp.169-191. In: Reclamation of Drastically Disturbed Lands, Agronomy No. 41. American Society of Agronomy, Madison, WI. 
Table 3-1. Discharge and Mine Overview

Discharge point, mine name, the year the mine opened, disturbance category ( $\mathrm{D}=$ disturbed and $\mathrm{UD}=$ undisturbed), coal seam mined (UF=Upper Freeport and Pitts=Pittsburgh), size of mine, and number of data points ( $2=1968$ and 2000, $3=1968,1980$, and 2000) for each discharge.

\begin{tabular}{|c|c|c|c|c|c|c|}
\hline Discharge Point & Mine Name & $\begin{array}{c}\text { Year } \\
\text { Opened }\end{array}$ & Category & $\begin{array}{r}\text { Coal } \\
\text { Seam } \\
\end{array}$ & $\begin{array}{l}\text { Size } \\
\text { (ha) }\end{array}$ & $\begin{array}{c}\text { Data } \\
\text { Points }\end{array}$ \\
\hline Bull Run 1 & Kimberly & 1955 & $\mathrm{D}$ & UF & 21 & 2 \\
\hline Bull Run 2 & Roxy Ann & 1957 & $\mathrm{D}$ & UF & 923 & 2 \\
\hline Bull Run 3 & Roxy Ann & 1957 & $\mathrm{D}$ & UF & 923 & 2 \\
\hline Bull Run 4 & Sherrey & 1955 & UD & UF & 282 & 3 \\
\hline Bull Run 5 & Marys & 1955 & UD & UF & 58 & 2 \\
\hline Cheat River 2 & Morgantown North D & 1935 & $\mathrm{D}$ & Pitts & 131 & 2 \\
\hline Cheat River 3 & Frederick No. 1 & 1938 & $\mathrm{D}$ & Pitts & 89 & 2 \\
\hline Cheat River 4 & Morgantown North A & 1940 & UD & Pitts & 44 & 3 \\
\hline Cheat River 5 & Canyon & 1940 & $\mathrm{D}$ & Pitts & 448 & 3 \\
\hline Cheat River 6 & Mountain Run & 1952 & $\mathrm{D}$ & UF & 311 & 2 \\
\hline Cheat River P1 & Morgantown North B & 1935 & $\mathrm{D}$ & Pitts & 63 & 2 \\
\hline Cheat River P2 & Morgantown North C & 1935 & UD & Pitts & 112 & 2 \\
\hline Fickey Run 1 & Valley Point C & 1945 & UD & UF & 28 & 2 \\
\hline Fickey Run 3 & Valley Point F & 1945 & $\mathrm{D}$ & UF & 62 & 3 \\
\hline Fickey Run 5 & Valley Point K & 1950 & $\mathrm{D}$ & UF & 38 & 3 \\
\hline Fickey Run 6 & Valley Point L & 1950 & $\mathrm{D}$ & UF & 75 & 3 \\
\hline Fickey Run 7 & Valley Point T & 1950 & $\mathrm{D}$ & UF & 60 & 2 \\
\hline Fickey Run 8 & Tri State & 1952 & $\mathrm{D}$ & UF & 78 & 3 \\
\hline Fickey Run 9 & Tri State 1 & 1945 & $\mathrm{D}$ & UF & 47 & 2 \\
\hline Glade Run 1 & Liston & 1955 & $\mathrm{D}$ & UF & 26 & 2 \\
\hline Glade Run 2 & Valley Point F & 1950 & UD & UF & 52 & 2 \\
\hline Glade Run 3 & Valley Point G & 1950 & UD & UF & 69 & 2 \\
\hline Glade Run 4 & Valley Point A & 1950 & $\mathrm{D}$ & UF & 156 & 3 \\
\hline Glade Run 5 & Valley Point A & 1950 & $\mathrm{D}$ & UF & 156 & 3 \\
\hline Green Run 1 & Pleasant & 1945 & UD & UF & 33 & 3 \\
\hline Green Run 2 & Ricks & 1945 & UD & UF & 42 & 2 \\
\hline Green Run 3 & Lowery & 1950 & $\mathrm{D}$ & UF & 88 & 3 \\
\hline Lake Lynn 1 & Hollow & 1943 & UD & Pitts & 34 & 3 \\
\hline Lake Lynn 2 & Canyon & 1935 & $\mathrm{D}$ & Pitts & 448 & 3 \\
\hline Lake Lynn 3 & Canyon & 1935 & $\mathrm{D}$ & Pitts & 448 & 3 \\
\hline Martin Ck 2 & $\mathrm{Me}$ & 1955 & $\mathrm{D}$ & UF & 11 & 3 \\
\hline Martin Ck 3 & $\mathrm{Me}$ & 1955 & D & UF & 11 & 2 \\
\hline Middle River 1 & Mountain Run & 1952 & $\mathrm{D}$ & UF & 310 & 3 \\
\hline Morgan Run 5 & Ford & 1940 & UD & UF & 41 & 2 \\
\hline Muddy Ck 2 & Cuzzart C & 1940 & UD & UF & 72 & 3 \\
\hline Muddy Ck 3 & Shermike & 1935 & $\mathrm{D}$ & UF & 278 & 3 \\
\hline Muddy Ck 4 & Pottage & 1940 & $\mathrm{D}$ & UF & 19 & 2 \\
\hline Muddy Ck 5 & Gloria & 1950 & UD & UF & 148 & 2 \\
\hline Muddy Ck 6 & Cuzzart B & 1945 & UD & UF & 98 & 2 \\
\hline Muddy Ck 7 & Cuzzart D & 1945 & $\mathrm{D}$ & UF & 86 & 2 \\
\hline Muddy Ck 8 & Cuzzart F & 1940 & UD & UF & 44 & 2 \\
\hline Muddy Ck 9 & Tri State & 1952 & D & UF & 78 & 3 \\
\hline Muddy Ck 10 & Short & 1940 & $\mathrm{D}$ & UF & 121 & 2 \\
\hline Muddy Ck 11 & Ruthbell \#3 & 1943 & $\mathrm{D}$ & UF & 35 & 3 \\
\hline
\end{tabular}


Table 3-2. Analysis of variance results and model fits for T\&T water quality data for 1996 to 2001.

\begin{tabular}{|c|c|c|c|c|c|c|}
\hline Months & Parameter & $\mathbf{R}^{2}$ & Model Pr>F & Month & Year & Month*Year \\
\hline & & & -------------- & 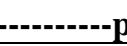 & & $\cdots$ \\
\hline \multirow[t]{6}{*}{ Jan - Dec } & Flow & 0.92 & $<0.0001$ & $<0.0001$ & $<0.0001$ & 0.0005 \\
\hline & Acidity & 0.59 & 0.0463 & 0.9777 & $<0.0001$ & 0.7448 \\
\hline & Iron & 0.73 & $<0.0001$ & 0.0033 & $<0.0001$ & 0.0244 \\
\hline & Sulfate & 0.80 & $<0.0001$ & 0.0184 & $<0.0001$ & 0.0004 \\
\hline & $\mathrm{pH}$ & 0.74 & $<0.0001$ & 0.0151 & $<0.0001$ & 0.0054 \\
\hline & Conductivity & 0.76 & $<0.0001$ & 0.0252 & $<0.0001$ & 0.1066 \\
\hline \multirow[t]{6}{*}{ Jun - Sept } & Flow & 0.85 & $<0.0001$ & 0.0186 & $<0.0001$ & 0.4278 \\
\hline & Acidity & 0.57 & 0.2527 & 0.9801 & 0.0133 & 0.8130 \\
\hline & Iron & 0.77 & 0.0035 & 0.0808 & $<0.0001$ & 0.1953 \\
\hline & Sulfate & 0.89 & $<0.0001$ & 0.2304 & $<0.0001$ & 0.0293 \\
\hline & $\mathrm{pH}$ & 0.49 & 0.5374 & 0.4216 & 0.1073 & 0.9846 \\
\hline & Conductivity & 0.80 & 0.0010 & 0.7003 & $<0.0001$ & 0.4952 \\
\hline
\end{tabular}

Table 3-3. Correlation coefficients between water quality parameters for the T\&T underground mine site.

\begin{tabular}{|c|c|c|c|c|c|c|c|}
\hline \multirow[b]{2}{*}{ Months } & \multirow[b]{2}{*}{ Parameter } & \multirow[b]{2}{*}{ Flow } & \multicolumn{5}{|c|}{ Parameter } \\
\hline & & & Acidity & Iron & Sulfate & pH & Cond \\
\hline \multirow[t]{6}{*}{ Jan - Dec } & Flow & 1.00 & $0.50^{* *}$ & $0.43^{* *}$ & $-0.17^{\mathrm{ns}}$ & $-0.42^{* *}$ & $0.46^{* *}$ \\
\hline & Acidity & & 1.00 & $0.46^{* *}$ & $0.18^{*}$ & $-0.35^{* *}$ & $0.51^{* *}$ \\
\hline & Iron & & & 1.00 & $0.15^{\mathrm{ns}}$ & $-0.38^{* *}$ & $0.42^{* *}$ \\
\hline & Sulfate & & & & 1.00 & $0.10^{\mathrm{ns}}$ & $0.12^{\mathrm{ns}}$ \\
\hline & $\mathrm{pH}$ & & & & & 1.00 & $-0.41^{* *}$ \\
\hline & Conductivity & & & & & & 1.00 \\
\hline \multirow[t]{6}{*}{ Jun - Sept } & Flow & 1.00 & $0.31^{*}$ & $0.39^{*}$ & $-0.26^{\mathrm{ns}}$ & $-0.30^{*}$ & $0.50^{* *}$ \\
\hline & Acidity & & 1.00 & $0.44^{* *}$ & $0.13^{\mathrm{ns}}$ & $-0.16^{\mathrm{ns}}$ & $0.42^{\text {** }}$ \\
\hline & Iron & & & 1.00 & $0.31^{*}$ & $-0.21^{\mathrm{ns}}$ & $0.32^{*}$ \\
\hline & Sulfate & & & & 1.00 & $0.23^{\text {ns }}$ & $0.04^{\mathrm{ns}}$ \\
\hline & $\mathrm{pH}$ & & & & & 1.00 & $-0.24^{\mathrm{ns}}$ \\
\hline & Conductivity & & & & & & 1.00 \\
\hline
\end{tabular}

${ }^{1} \mathrm{~ns}=$ not significant, ${ }^{*}=$ significant at the $\mathrm{p}=<0.05$ level, ${ }^{*}=$ significant at the $\mathrm{p}=<0.01$ level. 
Table 3-4. Characterization of T\&T flows and concentrations (1996 to 2001) across all months (January to December) and during low-flow sampling times (June to September).

\begin{tabular}{|c|c|c|c|c|c|c|}
\hline \multirow[b]{2}{*}{ Parameter } & \multicolumn{3}{|c|}{ January - December } & \multicolumn{3}{|c|}{ June - September } \\
\hline & mean & $\mathbf{R S D}^{\mathrm{a}}$ & $\%^{b}$ & mean & $\mathbf{R S D}^{\mathrm{a}}$ & $\%^{\mathrm{b}}$ \\
\hline Flow $\left(\mathrm{L} \mathrm{s}^{-1}\right)$ & 21.4 & 44.5 & -76.9 & 19.8 & 29.2 & -52.9 \\
\hline Acidity $\left(\mathrm{mmol} \mathrm{H}^{+} \mathrm{L}^{-1}\right)$ & 15.9 & 30.5 & -69.7 & 15.2 & 20.0 & -38.8 \\
\hline Iron $\left(\mathrm{mg} \mathrm{L}^{-1}\right)$ & 164 & 32.4 & -75.8 & 150 & 28.7 & -59.2 \\
\hline Sulfate $\left(\mathrm{mg} \mathrm{L}^{-1}\right)$ & 1346 & 19.1 & -55.5 & 1329 & 11.9 & -27.0 \\
\hline $\mathrm{pH}$ & 2.9 & 10.1 & -29.1 & 2.8 & 7.0 & -16.0 \\
\hline $\begin{array}{l}\text { Conductivity (mhos } \mathrm{cm} \\
{ }_{1} \text { ) }\end{array}$ & 3212 & 21.5 & -59.9 & 3131 & 9.1 & -25.9 \\
\hline
\end{tabular}

${ }^{\mathrm{a}} \mathrm{RSD}=$ relative standard deviation $=100 *$ standard deviation $/$ mean.

b $\%=$ percent change $=100 *($ minimum-maximum $) /$ maximum

Table 3-5. Average values for 1968 and 1999-2000 water quality data (two dates) from Pittsburgh and Upper Freeport underground mines.

\begin{tabular}{|c|c|c|c|c|c|}
\hline \multirow[b]{2}{*}{ Parameter } & \multirow[b]{2}{*}{ Coal Seam } & \multirow[b]{2}{*}{$\mathbf{n}$} & \multicolumn{2}{|c|}{ Year } & \multirow{2}{*}{$\begin{array}{c}\text { Significant } \\
\text { Between Dates }\end{array}$} \\
\hline & & & 1968 & 1999-2000 & \\
\hline Flow $\left(\mathrm{L} \mathrm{s}^{-1}\right)$ & ns & 42 & 1.4 & 0.5 & No \\
\hline \multirow[t]{2}{*}{ Acidity $\left(\mathrm{mmol} \mathrm{H}^{+} \mathrm{L}^{-1}\right)$} & Pittsburgh & 10 & $66.8^{\mathrm{a} 1}$ & $14.0^{\mathrm{a}}$ & Yes \\
\hline & Upper Freeport & 35 & $23.8^{\mathrm{b}}$ & $10.4^{\mathrm{a}}$ & Yes \\
\hline \multirow[t]{2}{*}{$\operatorname{Iron}\left(\mathrm{mg} \mathrm{L}^{-1}\right)$} & Pittsburgh & 10 & $591^{\mathrm{a}}$ & $88.1^{\mathrm{a}}$ & Yes \\
\hline & Upper Freeport & 35 & $214^{\mathrm{b}}$ & $54.7^{\mathrm{a}}$ & Yes \\
\hline \multirow[t]{2}{*}{ Sulfate $\left(\mathrm{mg} \mathrm{L}^{-1}\right)$} & Pittsburgh & 9 & $3581^{\mathrm{a}}$ & $1093^{\mathrm{a}}$ & Yes \\
\hline & Upper Freeport & 33 & $1561^{\mathrm{b}}$ & $886^{\mathrm{a}}$ & Yes \\
\hline \multirow[t]{2}{*}{$\mathrm{pH}$} & Pittsburgh & 10 & $3.0^{\mathrm{a}}$ & $3.0^{\mathrm{a}}$ & No \\
\hline & Upper Freeport & 35 & $3.1^{\mathrm{a}}$ & $3.8^{\mathrm{b}}$ & No \\
\hline \multirow[t]{2}{*}{ Conductivity (mhos $\mathrm{cm}^{-1}$ ) } & Pittsburgh & 10 & $5010^{\mathrm{a}}$ & $1826^{\mathrm{a}}$ & Yes \\
\hline & Upper Freeport & 25 & $2347^{\mathrm{b}}$ & $1764^{\mathrm{a}}$ & Yes \\
\hline
\end{tabular}

\footnotetext{
${ }^{1}$ Values for each parameter between coal seams with the same letter are not significantly different at the 0.05 level.
} 
Table 3-6. Average water quality value from Pittsburgh and Upper Freeport underground mines Average values for 1968, 1980, and 1999-2000 water quality data (three dates) from Pittsburgh and Upper Freeport underground mines. Trends across years are shown in Figures 3-4 through 3-6.

\begin{tabular}{|c|c|c|c|c|c|c|}
\hline \multirow[b]{2}{*}{ Significant Parameter } & \multirow[b]{2}{*}{ Coal Seam } & \multirow[b]{2}{*}{$\mathbf{n}$} & \multicolumn{3}{|c|}{ Year } & \multirow{2}{*}{$\begin{array}{c}\text { Significant } \\
\text { Among Dates }\end{array}$} \\
\hline & & & 1968 & 1980 & 1999-2000 & \\
\hline \multirow[t]{2}{*}{ Flow $\left(\mathrm{L} \mathrm{s}^{-1}\right)$} & Pittsburgh & 4 & 2.4 & 1.4 & 0.2 & No \\
\hline & Upper Freeport & 13 & 2.6 & 3.0 & 0.7 & No \\
\hline \multirow[t]{2}{*}{ Acidity $\left(\mathrm{mmol} \mathrm{H} \mathrm{H}^{+} \mathrm{L}^{-1}\right)$} & Pittsburgh & 5 & $65.9^{\mathrm{a} 1}$ & $17.3^{\mathrm{a}}$ & $13.1^{\mathrm{a}}$ & Yes \\
\hline & Upper Freeport & 15 & $23.5^{\mathrm{b}}$ & $12.7^{\mathrm{a}}$ & $5.2^{\mathrm{a}}$ & Yes \\
\hline \multirow[t]{2}{*}{ Iron $\left(\mathrm{mg} \mathrm{L}^{-1}\right)$} & Pittsburgh & 5 & $477^{\mathrm{a}}$ & $150^{\mathrm{a}}$ & $21^{\mathrm{a}}$ & Yes \\
\hline & Upper Freeport & 15 & $245^{\mathrm{b}}$ & $92^{\mathrm{a}}$ & $66^{\mathrm{a}}$ & Yes \\
\hline \multirow[t]{2}{*}{ Sulfate $\left(\mathrm{mg} \mathrm{L}^{-1}\right)$} & Pittsburgh & 5 & $2066^{\mathrm{a}}$ & $1244^{\mathrm{a}}$ & $580^{\mathrm{a}}$ & Yes \\
\hline & Upper Freeport & 14 & $1587^{\mathrm{a}}$ & $1050^{\mathrm{a}}$ & $1067^{\mathrm{a}}$ & Yes \\
\hline \multirow[t]{2}{*}{$\mathrm{pH}$} & Pittsburgh & 5 & $3.0^{\mathrm{a}}$ & $2.2^{\mathrm{a}}$ & $3.1^{\mathrm{a}}$ & Yes \\
\hline & Upper Freeport & 15 & $2.8^{\mathrm{a}}$ & $2.5^{\mathrm{a}}$ & $3.4^{\mathrm{a}}$ & Yes \\
\hline \multirow{2}{*}{$\begin{array}{l}\text { Conductivity (mhos } \mathrm{cm} \\
{ }^{1} \text { ) }\end{array}$} & Pittsburgh & 2 & $4472^{\mathrm{a}}$ & $2395^{\mathrm{a}}$ & $1065^{\mathrm{a}}$ & Yes \\
\hline & Upper Freeport & 10 & $1980^{\mathrm{b}}$ & $1104^{\mathrm{a}}$ & $1805^{\mathrm{a}}$ & Yes \\
\hline
\end{tabular}




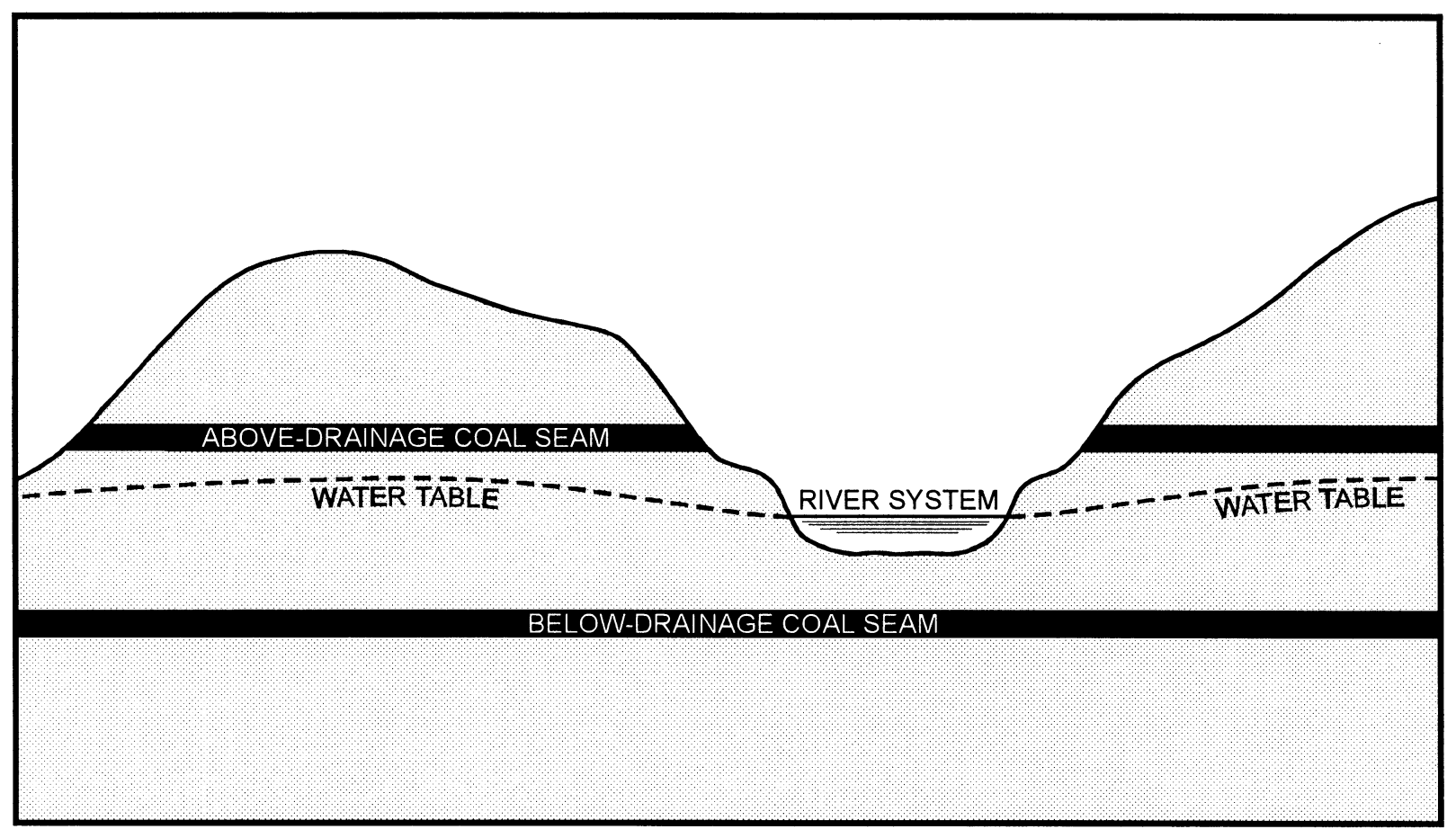

Figure 3-1. Below drainage vs. Above drainage

A simplified illustration of underground mines that are distinguished as "below-drainage" or "above-drainage." This refers to their capacity to be completely flooded after abandonment due to their relative location to the regional water table or regional flow system. See Callaghan et al. (1998) for a more thorough and detailed discussion of groundwater flow in the Appalachian Region. 

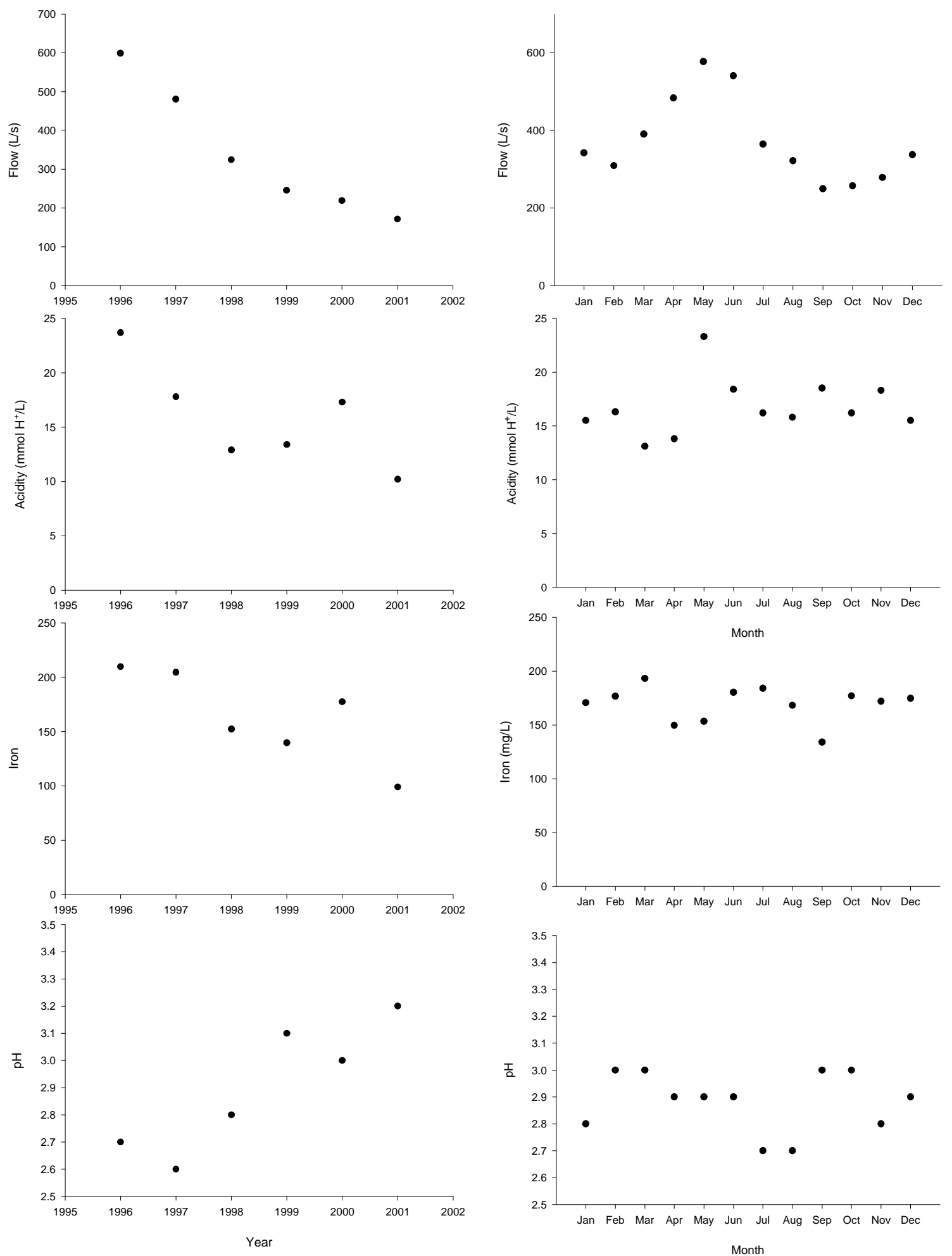

Figure 3-2. Average values for flow, acidity, iron, and pH across years and months for the T\&T data set. 


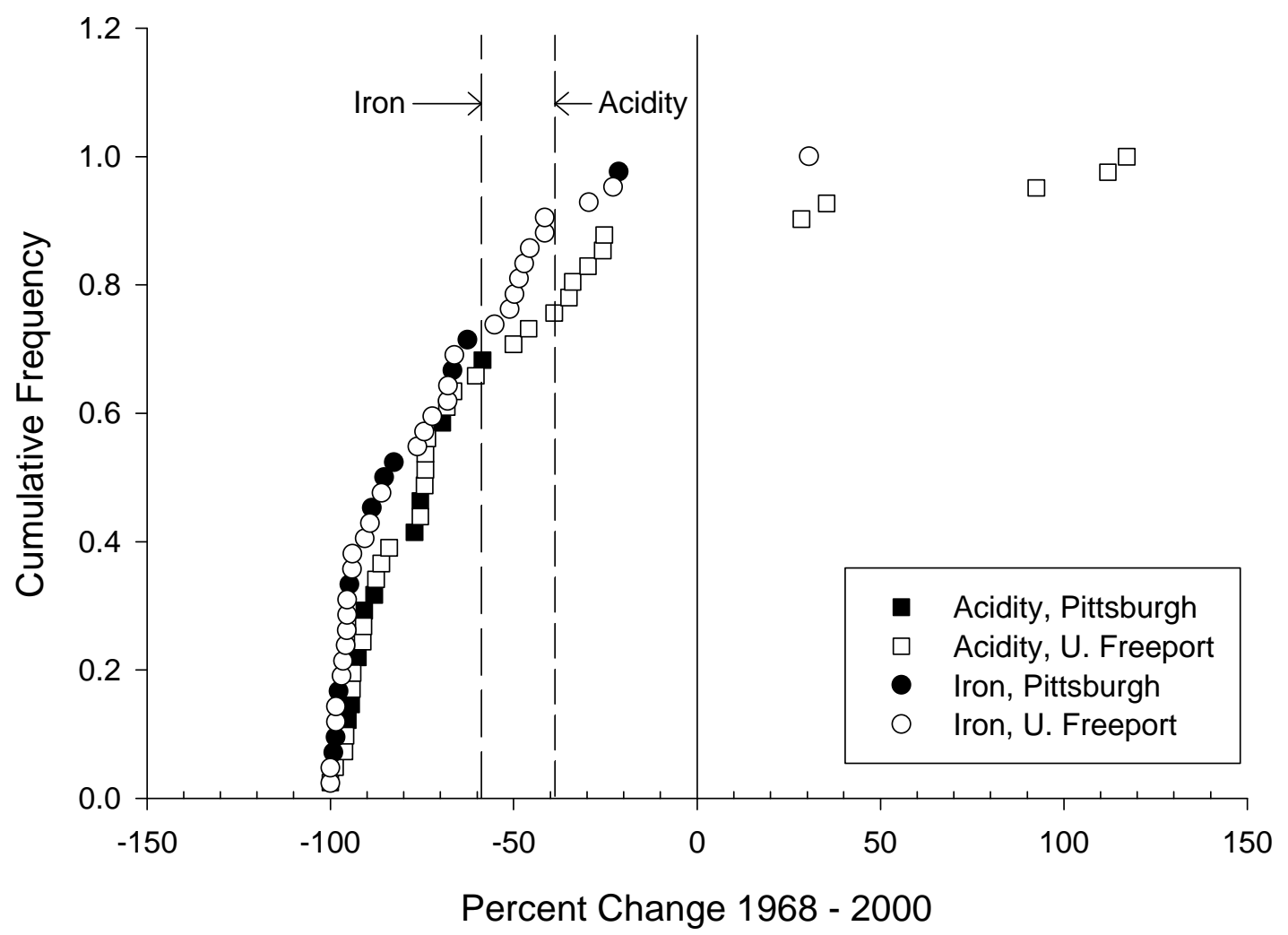

Figure 3-3. Cumulative frequency 1968 vs. 2000

Cumulative frequency plot for acidity and iron for two dates (1968 and 1999-2000). The percent change values of -38.8 for acidity and -59.2 for iron (Table 3-4) are used a conservative thresholds to indicate that changes more negative than these values are significantly different from a percent change of zero. 

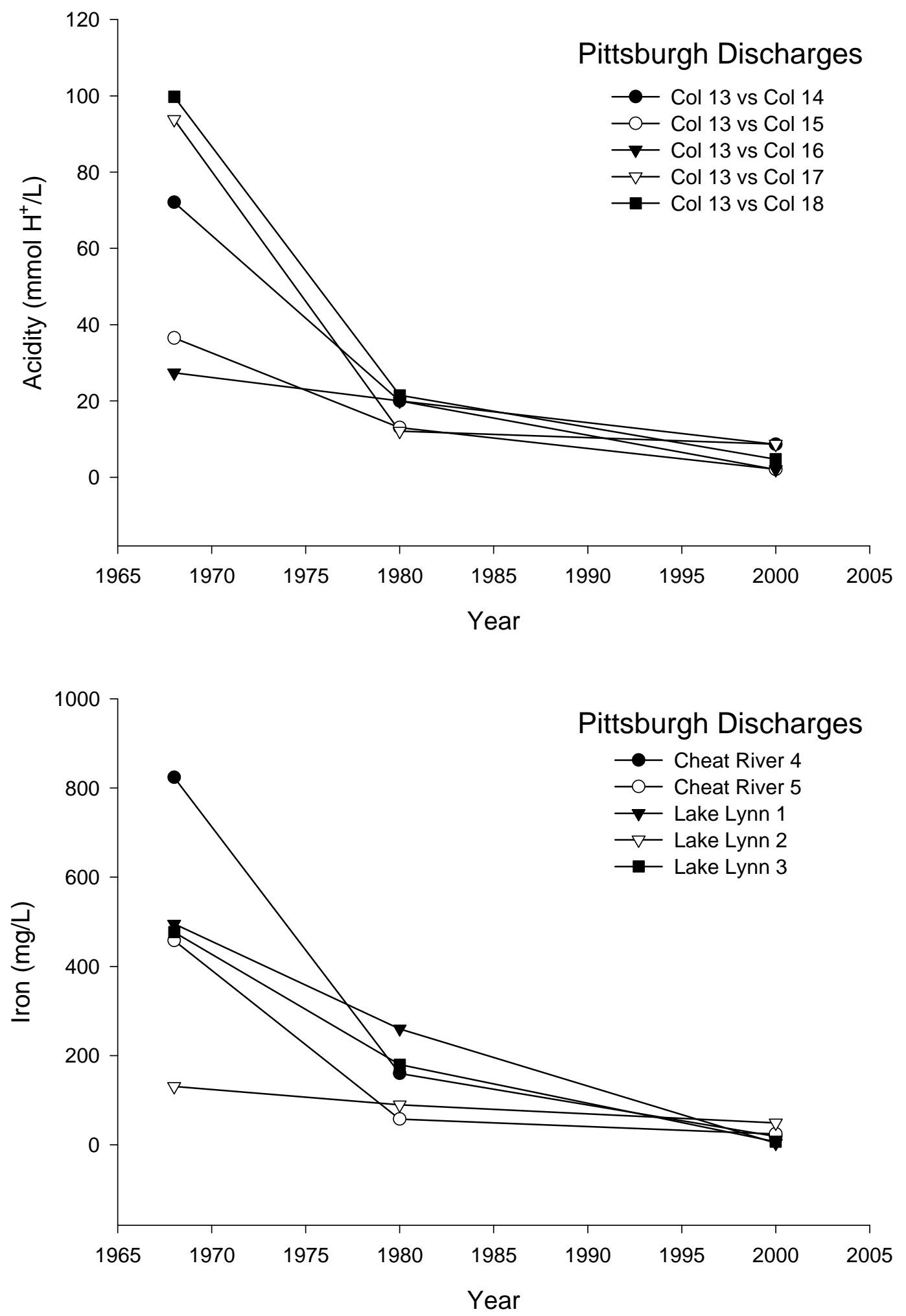

Figure 3-4. Pittsburgh acidity \& iron over years

Changes in acidity and iron for five Pittsburgh sites where we had data for 1968, 1980, and 1999-2000. All five sites showed decreasing acidity and iron values. 

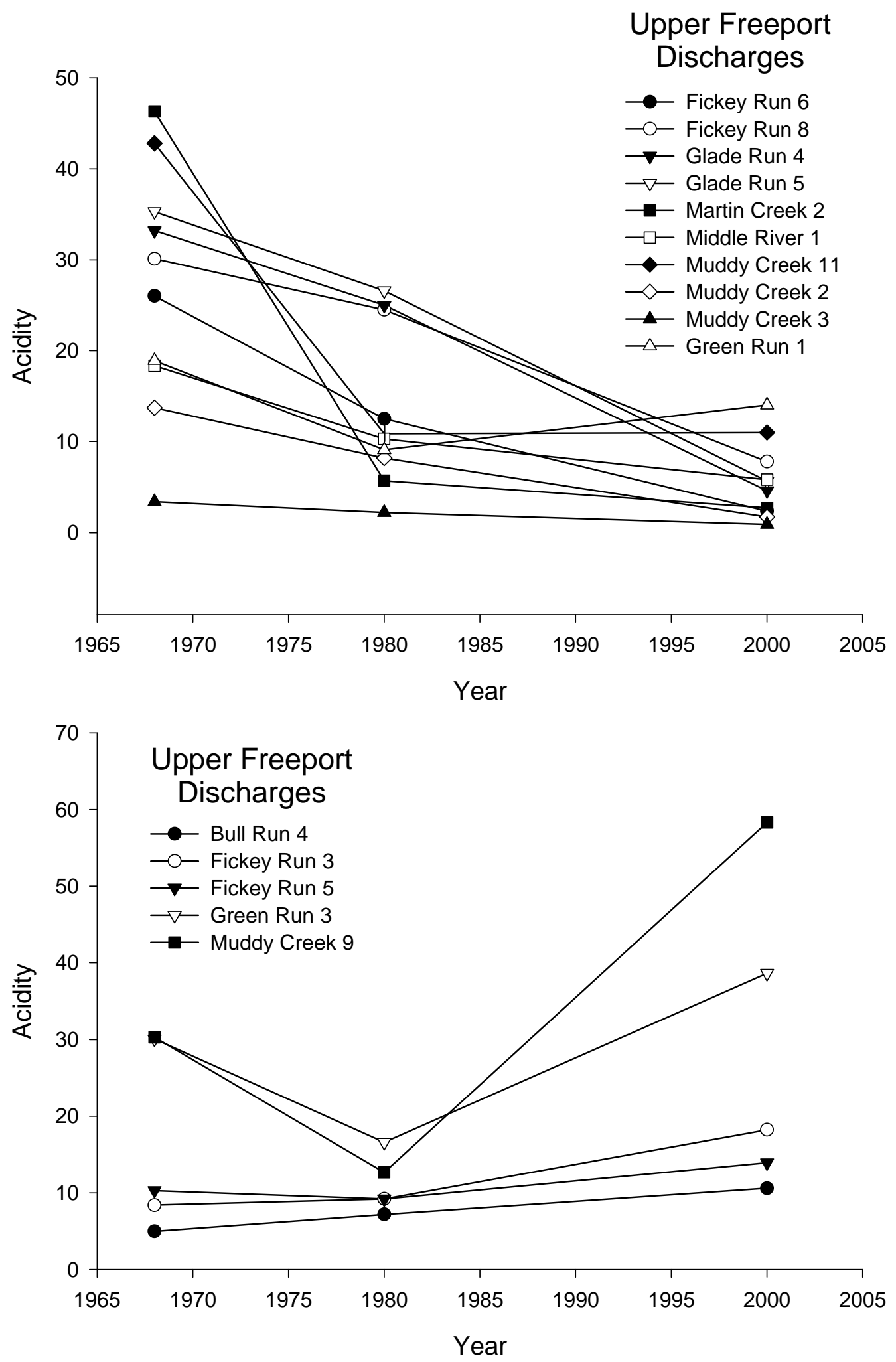

Figure 3-5. Changes in acidity for Upper Freeport sites

Changes in acidity for Upper Freeport sites where we had data for 1968, 1980, and 1999-2000. The top graph shows 10 sites with acidity decreases, while five sites showed acidity increases. 

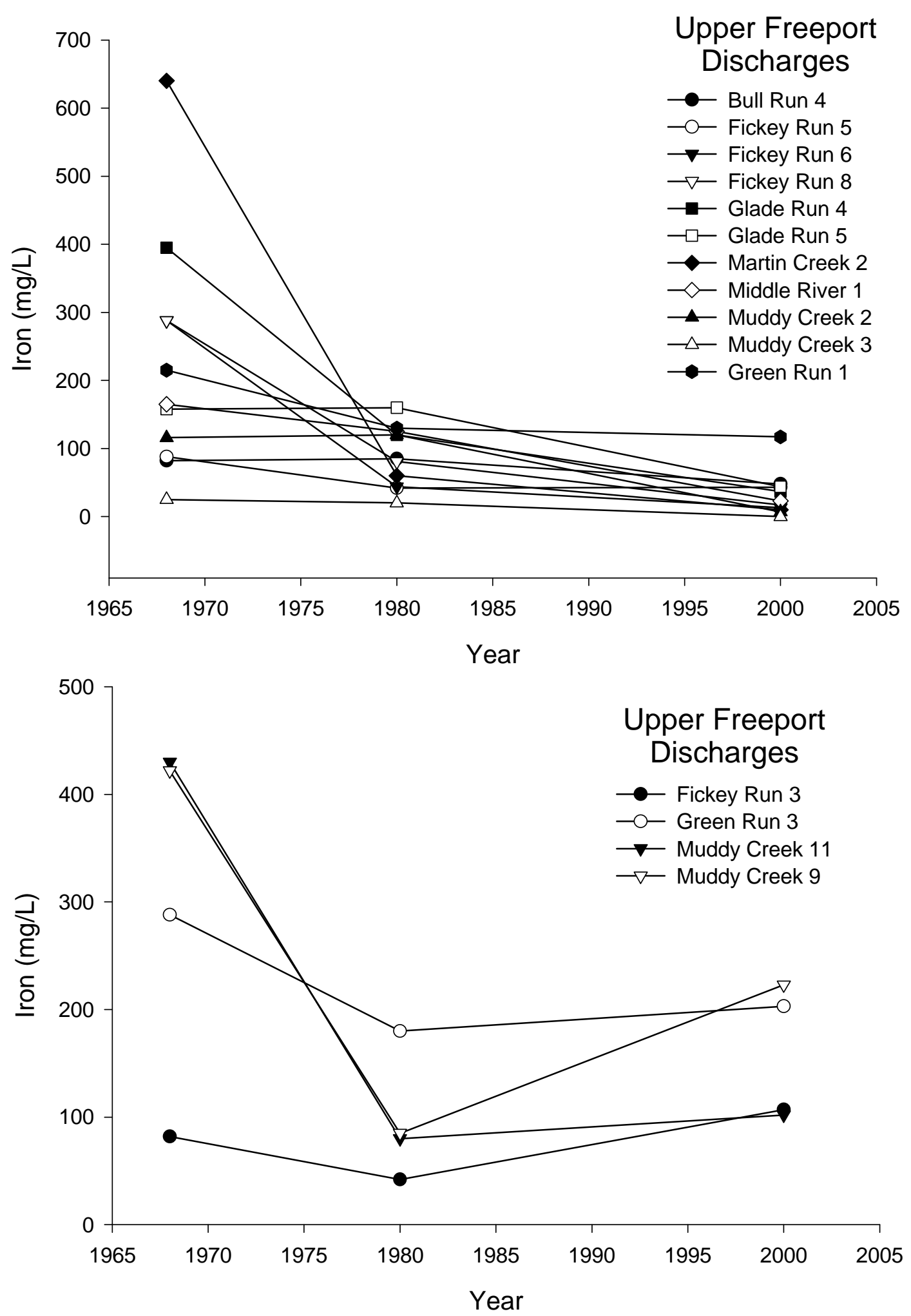

Figure 3-6. Changes in iron for Upper Freeport sites

Changes in iron for Upper Freeport sites where we had data for 1968, 1980, and 1999-2000. The top graph shows 11 sites with iron decreases, while four sites showed iron increases. 


\section{CHAPTER 4: FLOW EFFECTS ON ACIDITY AT TWO MINE SITES IN WV: OMEGA AND T\&T}

\section{Introduction}

It is apparent that precipitation influences the discharge rate of underground mines. Most recharge occurs in the fall, winter and especially spring causing increased flow rates as seen in the Appalachian Plateau Sandstone of central Pennsylvania (O'Driscoll et al. 2005). Wendland (2001) reported groundwater response within the month of precipitation events or one to two months later, with recovery being reached another one to three months in the future, depending on the season. During drought conditions, much longer recovery times are needed for increased discharge rate (Wendland 2001).

Pigati and Lopez (1999) studied the Majestic Mine in Ohio looking at seasonal variations in water chemistry. They report the Majestic Mine behaves similarly to a karst spring with quickflow and baseflow occurring, along with substantial subsidence causing the quick recharge into the mine. Their data supported the "spring flush" idea. The "spring flush" idea assumes that acidity and metals generated and deposited on surfaces during summer and fall (seasonal dry months in this region) are largely flushed from the mine with high flows from late winter-early spring snowmelt and rainfall. Therefore during the high recharge and discharge season of February to May (which also lacks evapotranspiration), the high water flows carry high concentrations of acidity and metals. This is opposed to the "high concentration at low flow" concept, where the worst drainage from underground mines happens at base flow conditions (dry months) where acid and metals are thought to be concentrated and not diluted by surface water during recharge events (Skousen and Ziemkiewicz 1996).

Further research by Lopez and Stoertz (2001) measured water chemistry and discharge rate of three up-dip mines of different sizes in the Monday and Raccoon Creek watersheds in eastern Ohio. They reported a 1- to 4-day time lag between precipitation and peak discharge in updrift mines in the Appalachian region, along with a seasonal affect. At the Majestic Mine, highest flows occurred in the spring $(130 \mathrm{~L} / \mathrm{s})$ with lows flows in the late summer and fall $(9 \mathrm{~L} / \mathrm{s})$. Lopez and Stoertz (2001) report iron and sulfate were highest during late winter and early spring at the Majestic Mine due to the water table rising, flushing out the oxidation products. However, they 
stated the drainage concentration was relatively uniform, suggesting either equilibrium controls on chemistry or drainage of a well mixed pool. Evidence by Borek et al (1991) contradicts this report. Studying underground mines in Randolph County, WV, they found that the highest flows were seen even when precipitation was below normal for a particular year.

Dyer (1986) showed that seasonal variation in chemistry occurred from auger mined sites in eastern Kentucky. Auger mining in this area is similar to underground mines which use continuous miners. The large augers leave 4 meter wide tunnels with pillars intact. A discharge from one of the tunnels had a $\mathrm{pH}$ of 2.7 and an acidity concentration of $5300 \mathrm{mg} / \mathrm{L}$ only a few hours after a heavy rainfall event in the spring of 1984. Dyer felt that the acidity was being flushed out of the mine tunnel. He corresponded these large increases of discharge from the mine into adverse affects being seen in the surrounding stream.

As presented by Demchak et al. (2004), the Omega Mine, a 68-ha above-drainage underground mine of the Upper Freeport coal bed in northern WV, was mined during the 1980s. In 1992, breakout of AMD caused mine closure, and flows and acidity concentrations were recorded continuously for the ensuing six years (GAI Consultants 2001). Acidity was highest during February to May ( 4,500 mg/L) compared to about 3,800 mg/L during June to January. However, variation in the acidity values across both time periods was high. Above drainage mines, based on these and other examples, appear to discharge their worst acid and metal concentrations during high flow seasons (spring flush), with improved water quality during dry periods.

Alternatively, Griffiths et al. (2001) indicate at the Arnot underground mine in Tioga County, PA, that as the discharge rate increased, other parameters (acidity, iron, and aluminum) decreased. This mine interestingly did not experience seasonal patterns, which may be explained by the wide range of "spring thaws" anytime from February to April skewing the trend.

Contradicting other reports, Lopez and Stoertz, (2001) suggest mine discharge chemistry may be relatively uniform through time, especially at small mines with little recharge, suggesting equilibrium control on chemistry within the mine or a well mixed pool. They report, using studies conducted in the Monday and Raccoon Creek watersheds in southeast Ohio that minimal evidence exists for dilution of chemistry by high flows, at least at the Carbondale mine. The Carbondale mine is only 13 ha, but is interconnected with 160 ha of additional mines. They state 
that slow sustained processes are occurring with this mine, versus quickflow processes which may occur at other mines.

It seems evident that discharge chemistry from underground mines is affected by several factors, and efforts to determine the changes in water quality over time require accounting for these factors. First, the season of sampling is important to consider due to varying recharge potential within the mine. However, conflicting results from other studies do not indicate that a particular time of year of sampling will produce accurate acidity results for a particular mine. Part of the problem lies in the fact that two distinct discharge periods are being documented in the WV region: February to May and June to September. Flows in October, November, December and January from underground mines are especially hard to predict because these months alternate between very high flows like those of February to May and very low flows like those from June to September (GAI Consultants 2001, Pigati and Lopez 1999). In fact, evidence is mounting that acidity does not vary significantly with flow.

In watersheds where many abandoned deep mines occur, the deep mines serve as a constant source of water to streams, sometimes called baseflow (Hobba 1981). During drier periods of the year, a larger degree of stream flow comes from deep mine drainage or baseflow, thereby causing very acidic water. During wetter periods, deep mine discharges, making up the majority of the baseflow, are diluted by ephemeral springs and seeps, and also by runoff, thereby resulting in improved water quality in streams. However, stream clean-up efforts must effectively deal with improving the water quality during baseflow conditions (improving the deep mine discharges) or else any enhancement in stream quality and aquatic habitat will be transitory and destroyed each time rainfall declines or is irregular. Therefore, it is vital to determine the origin of the deep mine discharges and whether the discharges improve over time and with seasonal rainfall variations.

In order to assess the relationship between discharge rates and acidity, two underground mines were studied. Data sets for T\&T and Omega were obtained from the West Virginia Division of Environmental Protection. These data sets were fairly complete in their daily precipitation and flow measurements, along with biweekly water quality analysis. The data sets were used to assess the relationships of precipitation, flow rates, and acidity concentrations. 


\section{Methods and Materials}

\section{$T \& T$}

T\&T is a 605-ha deep mine with three discrete parallel openings. The Freeport Coal (located at the top of the Allegheny Formation of the Pennsylvania Period) was mined at these sites using the room and pillar method. The pillars were left intact, creating a checkerboard in plane view as shown on mine maps. The coal seam averages $1.6 \mathrm{~m}$ in thickness; the dip is $9 \%$ to the southeast. The mines underlie an upland plateau dissected by Muddy Creek on the east and Cheat River on the south. Land surface elevation above these mines rises to a level of between $580 \mathrm{~m}$ to $640 \mathrm{~m}$, so that the overburden locally exceeds $90 \mathrm{~m}$. The \#2 portal opens on the west side of the valley of Muddy Creek at $455 \mathrm{~m}$ elevation. The overburden above Portal \#2 is about 12 to $30 \mathrm{~m}$. Geophysical approaches have been applied to determine mine pool information and flow within the mine workings. They have used very low frequency surveys coupled with magnetometers profiles. The traces do not appear to indicate the existence of fractures overlying the mine workings.

There are two discharges from this underground mine. Pitmouth is the primary portal of discharge as it is located $2.1 \mathrm{~m}$ lower than the Yellow Pipe. During dry periods, the Pitmouth discharge continually flows while the Yellow Pipe ceases to flow. The discharge rate from Pitmouth and Yellow Pipe were added together for total flow from T\&T. Weighted averages were calculated for acidity concentrations at T\&T. The acidity value was determined by first calculating the acid load at Pitmouth and Yellow Pipe, adding the two values together and then dividing by total flow. This gave a weighted acidity average at T\&T. This value was then compared against total flow in the analysis.

\section{Omega}

The Omega mine is located 2 miles south of Morgantown, WV and was closed in the early 1980s. The site is located in the Appalachian Plateau physiographic province. The rock strata is part of Pennsylvanian age Conemaugh and Allegheny Formations which consist of sandstone, claystone, limestone, and coal.

The UF bed is about $1.3 \mathrm{~m}$ thick at depths varying between 20 and $60 \mathrm{~m}$. The Upper Freeport coal bed was mined over 68 ha. The dip is to the southeast at 9\%. The elevation ranges from 530 
$\mathrm{m}$ above the mean sea level on the south end to $450 \mathrm{~m}$ at the north end. The mine was developed along a north to south ridgetop with the ridge serving as an anticline in the mine with sections on each side of the ridge being slightly lower. Water initially broke out on the eastern side of the mine, and a grouting project was attempted at the mine to fill the mine voids in specific places (WVDEP, personal communication).

Room and pillar methods extracted $50 \%$ of the coal with pillar size being from $5.5 \mathrm{~m}$ by $9 \mathrm{~m}$. Some areas had $60 \%$ coal removal, while others had $72 \%$ removal. Additional small UF mines were apparently operated in the vicinity in the 1920s, but no maps are available. When mining ceased in the 1980s water began ponding inside the mine, allowing two mine pools to develop. Unmapped punch mines have allowed water from Omega to drain through the outcrop. Steep slopes of $>30 \%$ cause rapid run-off and flash-flood type flow which results in limited recharge potential of the local aquifers and mine pool. A sandstone aquifer (Lower Mahoning) located above the UF bed is perched and of limited extent of area.

\section{Sampling}

Samples were collected by the West Virginia Division of Environmental Protection technicians and delivered to a certified laboratory where $\mathrm{pH}$, acidity, alkalinity, iron, aluminum, manganese, and sulfate were determined using standard methods. Flows were also taken by the technicians who worked at the mines every day using a flow gauge fitted to a v-notch weir. Precipitation was measured daily with a rain gauge located at the office trailer.

\section{Measured vs. Calculated Acidity}

When looking at the measured values of acidity from the data set, some of the data were suspect. In order to remove outliers and correct the data, a comparison between measured acidity to calculated acidity was done using the following formula (Skousen et al., 1998).

$$
\text { Calc Acidity }=50\left(2 \mathrm{Fe}^{2+} / 56+3 \mathrm{Fe}^{3+} / 56+3 \mathrm{Al}^{3+} / 27+2 \mathrm{Mn}^{2+} / 55+1000\left(10^{-\mathrm{pH}}\right)\right)
$$

The results showed that $T \& T$ had an $R^{2}=0.78$ while Omega had an $R^{2}=0.72$ (Figures 4-1 and 4-2). When measured acidity values were more than $10 \%$ different from calculated values, the calculated value was used. Outliers were removed from the datasets completely; 10 values were deleted from the T\&T dataset and 7 values were deleted from Omega. 


\section{Statistical Analysis}

A repeated measures analysis of variance with year, flow category, average flow, month, average precipitation, and season as categorical variables was used to test for the relationships between flow and acidity using PROC GLM (SAS Institute 1989). Means for significant (alpha= 0.05) model terms were separated using Tukey's Honestly Significant Difference (alpha = 0.05). Correlation analysis was also conducted on the raw water quality to look for overall trends.

In order to test for significance or trends within the data set, the data were broken into categories. Flow categories were determined by plotting raw flow data and visually observing data breaks. At T\&T the breaks were flows $<20 \mathrm{~L} / \mathrm{s}$ (300 gpm), flows between $20 \mathrm{~L} / \mathrm{s}$ (300 gpm) and $40 \mathrm{~L} / \mathrm{s}(600 \mathrm{gpm})$ and $>40 \mathrm{~L} / \mathrm{s}(600 \mathrm{gpm})$. At Omega the average flow was significantly smaller, so different breaks were used. The low flow was < $3 \mathrm{~L} / \mathrm{s}$ (50 gpm), between $3 \mathrm{~L} / \mathrm{s}$ (50 gpm) and $6 \mathrm{~L} / \mathrm{s}(100 \mathrm{gpm})$ and > $6 \mathrm{~L} / \mathrm{s}(100 \mathrm{gpm})$. Season was also tested in the model to determine if a seasonal trend s occurred. Four seasons were used: Summer (June, July, August), Fall (September, October and November), Winter (December, January, and February) and Spring (March, April, May).

\section{$\underline{\text { Results and Discussion }}$}

\section{Precipitation Effects on Flow Rate}

Since daily flow rates were available from T\&T and Omega, precipitation records were collected and plotted with flow rate. No estimates were made of other inputs or outflows from the mine such as barrier leakage, evaporation, transpiration or runoff. The main interest was to see trends of flow out of the mine with precipitation.

In this region of the U.S., rainfall is relatively evenly distributed throughout the year, with slightly higher rainfall in the spring, and slightly lower rainfall in the late summer and fall. Figures 4-3 and 4-4 showed this trend at these two mines. Patterns across season did emerge for flow rate. The highest flows were seen in the spring, while low flows were visible from late fall into winter. These results are similar to those found by Lopez and Stoertz (2001) at the Majestic Mine in Ohio. The Majestic Mine was 130 ha in size, but connects to about 360 ha of additional mines. This total size is much larger than the Omega mine, but not quite as large as the T\&T complex. 
As snow melt and spring rain occurs, the mine pool rises causing an increase in discharge rate. During the summer months when less precipitation falls, high intensity rainfall runs off, and evaporation and transpiration by vegetation is at a maximum, the mine pool lowers resulting in less water flowing from the portal during late summer and fall. This seasonal influence on flow will be used in the discussion on acidity concentrations.

It appears that the size of the mine or overburden depth does not affect the overall seasonal trend of flow rates. While the baseflows are significantly different at T\&T and Omega, discharge trends are similar at both mines. Baseflow for T\&T averaged $500 \mathrm{gpm}$ and baseflow for Omega averaging $80 \mathrm{gpm}$. During the spring when snow melt has occurring or greater amounts of precipitation are occurring, the flow rate increases. During the summer months, when evapotranspiration is at its highest and little to no recharge enters the mine, flow rates start to decrease through late summer into fall. This trend is clearly seen, regardless of the size of the mine.

\section{Acidity Values Plotted Over Time}

The average monthly flow and acidity were plotted over the study years for both T\&T and Omega. Flow showed the observed seasonal trends of troughs in the late summer through winter with high flow in the spring at T\&T (Figure 4-5). Acidity at this site does not show any clear visible trends except for a gradual overall decline. The regression line for T\&T (Figure 4-6) showed an increase in acidity with increased flow, but the fit was very poor $\left(\mathrm{R}^{2}=0.08\right)$. At Omega, the same pattern emerged for flow: troughs in the fall and winter with spikes in the spring (Figure 4-7). However, acidity appeared to decrease during high flow, but the overall fit was also poor $\left(\mathrm{R}^{2}=0.09\right.$, Figure $\left.4-8\right)$.

These relationships at both sites give evidence that flow has a very limited effect on acidity concentration from these above-drainage underground mines. Further, these results do not support either a flushing or a dilution idea. Lopez and Stoertz (2001) report equilibrium of chemistry within the mines which would account for the lack of trends between flow and acidity. The results from the present study seem to support this idea that no large fluctuations occur across seasons for acidity concentrations.

Lopez and Stoertz (2001) note the lack of trend strongly at the small Carbondale mine. This mine was only 13 ha in size, but was later found to be interconnected to an additional 160 ha of 
mines. This overall mine area is still relatively small. This lack of trend may be described by the potential equilibrium which may also be occurring at T\&T and Omega. A steady state has emerged within these mines due to the establishment of discrete mine pools within the complexes. Even though these mines are described as free flowing, that does not appear to be the case. Evidence at both sites show the formation of mine pools which may be acting to regulate flow, and therefore, chemistry out of the mine.

\section{Year, Seasonal and Monthly Flow Effects on Acidity}

In order to determine any other influence of flow on acidity, the data were divided into flow groups including year, flow category and season. Each flow group was analyzed as main effects with all interactions. The $\mathrm{R}^{2}$ at both sites was 0.82 . The overall model at both sites was significant, $\mathrm{T} \& \mathrm{~T}=0.0007$ and Omega $=0.0003$. Individual model terms showed significant differences in acidity averages across years at T\&T (Tables 4-1 and 4-2). The acidity means ranged from $565 \mathrm{mg} / \mathrm{L}$ in 2002 to $1127 \mathrm{mg} / \mathrm{L}$ in 1996. Omega also showed significant differences in acidity across years (Tables 4-3 and 4-4) ranging from $945 \mathrm{mg} / \mathrm{L}$ in 2002 to 1616 $\mathrm{mg} / \mathrm{L}$ in 2000. There appears to be no strong trend for acidity decreasing over time as reported in Chapter 1 for similar above drainage mines. This, however, is most likely due to the relatively short time since these two mines have been closed. Figures 4-9 and 4-13 represent acidity concentrations as grouped per year. The wide variation within a year can be seen in these graphs.

T\&T and Omega both resulted in year being significant as a model term, this would be expected. Acidity concentrations will vary from year to year as affected by cumulative precipitation and depth of the mine pools. A high precipitation year would increase recharge into the mine, raising the mine pool elevations, allowing the water to contact oxidation products which would have accumulated during dry times. These products would then dissolve and be removed from the mine as increased acidity concentrations. These variations would be expected at both mines during wet and dry years.

The second main effect term in this model was flow category. Flow categories were determined by plotting raw flow data and visually observing data breaks. At T\&T the breaks were flows $<20 \mathrm{~L} / \mathrm{s}(300 \mathrm{gpm})$, flows between $20 \mathrm{~L} / \mathrm{s}(300 \mathrm{gpm})$ and $40 \mathrm{~L} / \mathrm{s}(600 \mathrm{gpm})$ and $>40$ $\mathrm{L} / \mathrm{s}$ (600 gpm). At Omega the average flow was much smaller due to the much smaller size, so different breaks were used. The low flow was < $3 \mathrm{~L} / \mathrm{s}$ (50 gpm), between $3 \mathrm{~L} / \mathrm{s}$ (50 gpm) and 6 
L/s (100 gpm) and > 6 L/s (100 gpm) (Table 4-5). Flows were divided into Low, Mid, and High categories and acidity mean concentrations corresponding to these flow categories were calculated. At T\&T, the ANOVA showed no significant difference in flow categories with acidity values ranging from $718 \mathrm{mg} / \mathrm{L}$ for Low to $875 \mathrm{mg} / \mathrm{L}$ for High (Table 4-1). At Omega, the overall model showed a significance of the year and flow category interaction $(p=0.0036)$, but not for flow category as a main effect. Acidity values ranged from $1518 \mathrm{mg} / \mathrm{L}$ for Low and 1157 mg/L for Mid. Figure 4-12 shows acidity concentration as grouped by flow category at T\&T. This graph shows a strong correlation (0.92) for increasing acidity as flow increases, but the data is highly variable with the Low and Mid categories having as high acidity values as the High category. A similar result is shown for Omega (Figure 4-16). Both Pigati and Lopez (1999) and Dyer (1986) report results describing situations where high flows resulted in high acidities. They state that during high flows or soon after high precipitation events, flushing of acidity from the underground mines occur. In this study, variation in acidity values was very high among the flow categories that a similar conclusion could not be reached.

The third main effect term in this model was season. Seasonal trends in acidity were marginally significant in the ANOVA model for $\mathrm{T} \& \mathrm{~T}(\mathrm{p}=0.0551)$. At $\mathrm{T} \& \mathrm{~T}$, the highest acidity concentration occurred in the summer months at $813 \mathrm{mg} / \mathrm{L}$, but the lowest was in the spring at $770 \mathrm{mg} / \mathrm{L}$, neither being very different from the other. The large size of T\&T may act to buffer the spring thaw resulting in a delayed flush event. At Omega, similar results were seen with Season being marginally significant $(\mathrm{p}=0.0682)$, whereas the interaction of flow category and season was also marginally significant $(\mathrm{p}=0.0577)$. At Omega, the highest acidity values occurred in the spring $(1383 \mathrm{mg} / \mathrm{L})$ and the lowest mean was in the winter $(1206 \mathrm{mg} / \mathrm{L})$. The flush events are occurring during the high seasonal recharge at this smaller mine, which also has shallower overburden allowing for "quickflow" to occur.

There were no clear trends across sites. Figures 4-9 to 4-16 provide relationships between flow groupings and acidity values and present the wide variation across years, flow categories, and seasons. In general, these graphs give further evidence of the lack of trends between acidity concentrations and flow. The lack of seasonal trends was also reported by Griffiths et al. (2001) for work conducted at the Arnot mine in Pennsylvania. He credited this lack of seasonality to the wide range or time frame in which spring thaws occur in northern Pennsylvania and that flow was therefore relatively constant across seasons. 
Analyses were then performed on individual flow values within flow groupings by using a model of acidity $=$ year $*$ average flow $*$ season. At $\mathrm{T} \& \mathrm{~T}$, the $\mathrm{R}^{2}$ was 0.92 with a significant overall model of 0.0012 . The model interaction of year and season $(\mathrm{p}=0.0488)$ was significant, but no individual terms were significant. The Tukey results gave significant differences among years, but not seasons. At Omega, the $\mathrm{R}^{2}$ was 0.88 with an overall model significance (0.0190). However, with Omega there was no significance for individual model terms or interactions. The results are therefore similar to those using the flow categories.

An analysis was also performed for months using a model of acidity $=$ average flow $*$ month. No significance was determined at either site. Figures 4-11 and 4-15 show the variation of acidity across months. It was thought that differences in months may occur if there is truly one time of year when "flush events" are occurring. This was expected more at Omega due to the size of the mine.

Tables 4-6 and 4-7 summarize the average precipitation received for years, seasons and flow categories, and provide the average flows and average acidity values. At both T\&T and Omega, flow appears related to the cumulative precipitation. Lower flows are associated with a lower cumulative precipitation for a given year or season. Acidity, however, does not show a similar trend. An ANOVA model was ran using flow category and average precipitation as main effect with interactions (model results not shown). The $\mathrm{R}^{2}$ was 0.09 at $\mathrm{T} \& \mathrm{~T}$, with no overall or individual significance. At Omega, an $\mathrm{R}^{2}$ of 0.21 was shown, again with no significance of a whole model or individual terms. Average precipitation does not affect the acidity concentration, but it is more the cumulative precipitation and its subsequent effect on flow which plays the larger role.

\section{Daily Flow Effects on Acidity}

Questions remain as to how acidity concentrations may be influenced by more localized events such as those during brief dry periods or shortly after large rainfall events. This was difficult because daily flow values did not have corresponding daily acidity values. Table 4-8 gives data that represent both dry and wet events at T\&T. The first part of the table shows precipitation events greater than $1.3 \mathrm{~cm}$ and how many days after that event where both acidity and flow were measured simultaneously. The days range from 1 to 7 days after the rain event. For example, on 9 April 2001, which was two days after a $2.1 \mathrm{~cm}$ rainfall event, the acidity was 
$596 \mathrm{mg} / \mathrm{L}$ with a flow of $28 \mathrm{~L} / \mathrm{s}$ (452 gpm). On 1 April 2003 (during the same month and season), two days after a $1.3 \mathrm{~cm}$ rainfall event, the acidity was $1100 \mathrm{mg} / \mathrm{L}$ with a flow of $46.3 \mathrm{~L} / \mathrm{s}$ (735 gpm). Therefore, the flow and acidity do not appear to relate to an individual rainfall event, but may related to the cumulative precipitation. 2003 was a much wetter year than 2001. On 29 January 1997, the acidity was $851 \mathrm{mg} / \mathrm{L}$ with a flow of $33 \mathrm{~L} / \mathrm{s}$ (533 gpm). On 12 November 1996, the acidity was $803 \mathrm{mg} / \mathrm{L}$ at a flow of $34 \mathrm{~L} / \mathrm{s}$ (536 gpm). In this example, similar flows resulted in similar concentrations. When looking at other dates, the effect of rainfall events after dry periods shows no evidence of patterns.

The second part of Table 4-8 shows the acidity and flow values during dry conditions of no rain. Dry periods of 7 days resulted in acidity values ranging from 211 to $288 \mathrm{mg} / \mathrm{L}$, while a dry period of 3 days gave acidity values from 497 to $3310 \mathrm{mg} / \mathrm{L}$. This continues to show the wide variation in acidity values across years, seasons, and even short-term dry periods.

At Omega, the results are similar to T\&T with the same analysis (Table 4-9). For example, on 14 April 2000, five days after a $1.7 \mathrm{~cm}$ event, the flow was $13 \mathrm{~L} / \mathrm{s}$ ( $209 \mathrm{gpm}$ ) with an acidity of $1880 \mathrm{mg} / \mathrm{L}$, while one year later on 16 April 2001, four days after a $1.4 \mathrm{~cm}$ event, the flow was identical at $13 \mathrm{~L} / \mathrm{s}$ (209 gpm) but the acidity was cut nearly in half to $1000 \mathrm{mg} / \mathrm{L}$. The cumulative rainfall was similar among years. During dry periods, the data also lacked a clear trend. On 13 Oct 2003, 7 days of no rain produced a flow of $3 \mathrm{~L} / \mathrm{s}$ (53 gpm) and an acidity of $1200 \mathrm{mg} / \mathrm{L}$, while on 15 November 2001, 7 days of no rain produced a flow of $1 \mathrm{~L} / \mathrm{s}$ (17 gpm) and an acidity of $1460 \mathrm{mg} / \mathrm{L}$.

\section{Conclusion}

Graphs plotting precipitation and flow data showed that the highest flows generally occurred in the spring, with low flows in the fall. These conclusions were also reached by Lopez and Stoertz (2001) when working with up-dip above-drainage underground mines in Ohio. While the statistics are not shown here, there is no statistical evidence showing that average precipitation directly affected flow rate.

In comparing measured to calculated acidity, the $\mathrm{R}^{2}$ was greater than 0.70 for both sites. The time graphs showed no clear acidity trends with flow. There was slight evidence for lower flows to result in higher acidity values at Omega. These results are supported by work done at the 
Arnot mine in Pennsylvania which showed that there were no differences in acidity values across different flow times.

Significant differences were seen in acidity across years at both sites, with acidity values decreasing over time. Flow category had no significance on acidity values at T\&T. This contradicts trends identified by other studies in Ohio and Kentucky which reported higher acidity concentrations at higher flows. At Omega, the individual flow category term was not significant, but the flow category* year interaction was. This site showed significantly higher acidity values at low flows. There was no difference for acidity values within a season at T\&T and Omega.

Analysis of flow and acidity data from these two mines gave weak relationships between flow rates and acidity concentrations. While two ideas have existed about flow rate on discharge acidity concentration from above drainage underground mines (flushing versus dilution), neither idea is strongly supported by this analysis. Changes occurred within these mines during the study period that may have confounded the data and made our conclusions suspect. Both sites had grouting and alkalinity injection within the mine. While recognizing these disturbance effects, these mines were the only ones where a sufficient data set with daily flows and frequent analysis provided the opportunity to evaluate these trends.

\section{Literature Cited}

Borek S. L., T. E. Ackman, G. P. Watzlaf, R. W. Hammack, and J. P. Lipscomb. 1991. The long-term evaluation of mine seals constructed in Randolph County, W.V. in 1967. In: Proceedings of the 12th Annual West Virginia Surface Mine Drainage Task Force Symposium, April 3-4, 1991, Morgantown, W.V.

Demchak, J., J. Skousen, and L.M. McDonald. 2004. Longevity of acid discharges from underground mines lying above the regional water table. J. Environ. Qual. 33: 656-668.

Dyer, Kenneth. 1986. Seasonal acid mine drainage from a surface mined watershed in eastern Kentucky. In: Proceedings of American Society for Surface Mining and Reclamation. Jackson, Mississippi.

GAI Consultants. 2001. Omega Mine injection program: Monongalia County, West Virginia. Electric Power Research Institute, Inc. (EPRI), Allegheny Energy Supply, and the U.S. Department of Energy. Document \#1004032. USDOE. Pittsburgh, PA. 
Griffiths, J.C., R.J. Hornberger, K. Miller, and M.W.Smith 2001. Statistical analysis of abandoned mine drainage in the assessment of pollution load ("The Griffiths Report"). EPA821-B-01-014.

Hobba, W.A. 1981. Effects of underground mining and mine collapse on the hydrology of selected basins in WV. USGS, Report of Investigation, RI-33.

Lopez, D.L. and M.W. Stoertz. 2001. Chemical and physical controls on waters discharged from abandoned coal mines. Geochemistry: Exploration, Environment, Analysis 1: 51-60.

O’ Driscoll, M.A., D.R. DeWalle, K.J. McGuire, and W.J. Gburek. 2005. Seasonal variations and groundwater recharge for three landscape types in central Pennsylvania, USA. $J$. Hydrology. 303: 108-124.

Pigati, E., and D. Lopez. 1999. Effect of subsidence on recharge at abandoned coal mines generating acidic drainage: the Majestic Mine, Athens County, $\mathrm{OH}$. Mine Water and the Environment 18(1): 45-66.

SAS Institute. 1989. SAS. SAS Institute. Cary, NC.

Skousen, J., and P. Ziemkiewicz. 1996. Acid mine drainage control and treatment. National Research Center for Coal and Energy, West Virginia University, Morgantown, WV.

Skousen, J., A. Rose, G. Geidel, J. Foreman, R. Evans, W. Hellier. 1998. Handbook of technologies for avoidance and remediation of acid mine drainage. Acid Drainage Technology Initiative (ADTI) of the U.S. Office of Surface Mining. National Mine Land Reclamation Center, West Virginia University. Morgantown, WV.

Wendland, W.M. 2001. Temporal responses of surface water and groundwater to precipitation in Illinois. J. American Water Resources Associations. 37: 685-693.

WVDEP personal communication. 
Table 4-1: Characterization of T\&T flows and acidity (1996 to 2003) using Tukey analysis.

\begin{tabular}{|c|c|c|c|c|c|c|}
\hline Model & Year & $\begin{array}{c}\text { Acidity } \\
\text { Mean }\end{array}$ & $\begin{array}{c}\text { Flow } \\
\text { Category } \\
\end{array}$ & $\begin{array}{c}\text { Acidity } \\
\text { Mean }\end{array}$ & Season & $\begin{array}{c}\text { Acidity } \\
\text { Mean }\end{array}$ \\
\hline Year $* \mathrm{FC} *$ Season & $\begin{array}{l}1996 \\
1997 \\
1998 \\
1999 \\
2000 \\
2001 \\
2002 \\
2003 \\
\end{array}$ & $\begin{array}{c}1127^{\mathrm{a}} \\
914^{\mathrm{ab}} \\
700^{\mathrm{bc}} \\
736^{\mathrm{bc}} \\
871^{\mathrm{ab}} \\
589^{\mathrm{c}} \\
565^{\mathrm{c}} \\
1054^{\mathrm{a}}\end{array}$ & $\begin{array}{l}\text { Low } \\
\text { Mid } \\
\text { High }\end{array}$ & $\begin{array}{c}718^{\mathrm{a}} \\
789^{\mathrm{ab}} \\
875^{\mathrm{b}}\end{array}$ & $\begin{array}{c}\text { Summer } \\
\text { Fall } \\
\text { Winter } \\
\text { Spring }\end{array}$ & $\begin{array}{l}813^{\mathrm{a}} \\
805^{\mathrm{a}} \\
811^{\mathrm{a}} \\
770^{\mathrm{a}}\end{array}$ \\
\hline
\end{tabular}

Table 4-2: Analysis of variance results and model fits for T\&T water quality data for 1996 to 2003.

\begin{tabular}{lrlr}
\hline Year * Flow Category * Season & & Year * Avg Flow * Season & Acidity \\
\hline Mean & Acidity & & 800 \\
MSE & 800 & Mean & 125 \\
$\mathrm{R}^{2}$ & 150 & MSE & 0.92 \\
Pr $>\mathrm{F}$ & 0.82 & $\mathrm{R}^{2}$ & 0.0012 \\
\hline & 0.0007 & Pr $>\mathrm{F}$ & $\mathbf{p}$-value \\
\hline Year & p-value & & 0.3915 \\
FC & 0.0039 & Year & 0.8056 \\
Year * FC & 0.9973 & Average Flow & 0.2780 \\
Season & 0.3202 & Year * Avg Flow & 0.6213 \\
Year * Season & 0.0551 & Season & 0.0488 \\
FC $*$ Season & 0.3577 & Year * Season & 0.7863 \\
Year * FC * Season & 0.7657 & Avg Flow * Season & 0.0830 \\
\hline
\end{tabular}


Table 4-3: Characterization of Omega flows and acidity (2000 to 2003) using summary statistics and Tukey analysis.

\begin{tabular}{ccccccc}
\hline Model & Year & $\begin{array}{c}\text { Acidity } \\
\text { Mean }\end{array}$ & $\begin{array}{c}\text { Flow } \\
\text { Category }\end{array}$ & $\begin{array}{c}\text { Acidity } \\
\text { Mean }\end{array}$ & Season & $\begin{array}{c}\text { Acidity } \\
\text { Mean }\end{array}$ \\
\hline Year * FC * Season & 2000 & $1616^{\mathrm{a}}$ & Low & $1518^{\mathrm{a}}$ & Summer & $1256^{\mathrm{a}}$ \\
& 2001 & $1515^{\mathrm{a}}$ & Mid & $1157^{\mathrm{b}}$ & Fall & $1317^{\mathrm{a}}$ \\
& 2002 & $945^{\mathrm{b}}$ & High & $1222^{\mathrm{b}}$ & Winter & $1206^{\mathrm{a}}$ \\
& 2003 & $1070^{\mathrm{b}}$ & & & Spring & $1383^{\mathrm{a}}$ \\
\hline
\end{tabular}

Table 4-4: Analysis of variance results and model fits for Omega water quality data for 2000 to 2003.

\begin{tabular}{lrlr}
\hline Year * Flow Category * Season & & Year * Avg Flow * Season & \\
\hline & Acidity & & Acidity \\
\hline Mean & 1294 & Mean & 1294 \\
MSE & 283 & MSE & 301 \\
$\mathrm{R}^{2}$ & 0.82 & $\mathrm{R}^{2}$ & 0.88 \\
$\mathrm{Pr}>\mathrm{F}$ & 0.0003 & Pr $>\mathrm{F}$ & 0.0190 \\
\hline & p-value & & p-value \\
\hline Year & 0.0003 & Year & 0.2768 \\
$\mathrm{FC}$ & 0.2173 & Average Flow & 0.2734 \\
Year * FC & 0.0036 & Year* Avg Flow & 0.4075 \\
Season & 0.0682 & Season & 0.8036 \\
Year * Season & 0.1642 & Year * Season & 0.2611 \\
FC * Season & 0.0577 & Avg Flow * Season & 0.7677 \\
Year * FC * Season & na & Year * Avg Flow * Season & 0.3589 \\
\hline
\end{tabular}

Table 4-5: Description of data categories for T\&T and Omega using flow categories.

\begin{tabular}{lccc}
\hline \multicolumn{1}{c}{ Site } & Category & Range & Count \\
\hline T\&T & Low & $<300$ & 26 \\
& Mid & $300-600$ & 29 \\
\multirow{3}{*}{ Omega } & High & $>600$ & 29 \\
& Low & $<50$ & 15 \\
& Mid & $50-100$ & 13 \\
& High & $>100$ & 11 \\
\hline
\end{tabular}


Table 4-6. Average flow $\&$ acidity for $T \& T$ by category

Average values for flow and acidity on a daily basis at the T\&T mine divided into year, season and categories. The total cumulative precipitation for year, season, and category is also presented.

\begin{tabular}{|c|c|c|c|}
\hline Year & $\begin{array}{c}\text { Total Cumulative Precip for } \\
\text { Year }(\mathrm{cm})\end{array}$ & $\begin{array}{c}\text { Average Flow } \\
(\mathrm{L} / \mathrm{s})\end{array}$ & $\begin{array}{c}\text { Average Acidity } \\
(\mathrm{mg} / \mathrm{L})\end{array}$ \\
\hline 1996 & 166 & 43 & 1127 \\
\hline 1997 & 145 & 36 & 914 \\
\hline 1998 & 139 & 37 & 700 \\
\hline 1999 & 104 & 19 & 736 \\
\hline 2000 & 145 & 31 & 871 \\
\hline 2001 & 136 & 37 & 402 \\
\hline 2002 & 139 & 37 & 264 \\
\hline 2003 & 184 & 34 & 1054 \\
\hline Season & $\begin{array}{c}\text { Avg Precip per Season } \\
(\mathrm{cm})\end{array}$ & $\begin{array}{c}\text { Average Flow } \\
(\mathrm{L} / \mathrm{s})\end{array}$ & $\begin{array}{c}\text { Average Acidity } \\
(\mathrm{mg} / \mathrm{L})\end{array}$ \\
\hline Summer & 41 & 32 & 813 \\
\hline Fall & 31 & 15 & 805 \\
\hline Winter & 29 & 30 & 811 \\
\hline Spring & 43 & 43 & 770 \\
\hline Flow Category & $\begin{array}{c}\text { Avg Precip per day } \\
(\mathrm{cm})\end{array}$ & $\begin{array}{c}\text { Average Flow } \\
(\mathbf{L} / \mathbf{s})\end{array}$ & $\begin{array}{c}\text { Average Acidity } \\
(\mathrm{mg} / \mathrm{L})\end{array}$ \\
\hline Low & 0.3 & 11 & 718 \\
\hline Mid & 0.4 & 29 & 789 \\
\hline High & 0.5 & 47 & 875 \\
\hline
\end{tabular}

Table 4-7. Average flow \& acidity for Omega by category Average values for flow and acidity on a daily basis at the Omega mine divided into year, season and categories. The total cumulative precipitation for year, season, and category is also presented.

\begin{tabular}{|c|c|c|c|}
\hline Year & $\begin{array}{c}\text { Total Cumulative Precip for } \\
\text { Year }(\mathbf{c m})\end{array}$ & $\begin{array}{c}\text { Average Flow } \\
(\mathrm{L} / \mathrm{s})\end{array}$ & $\begin{array}{c}\text { Average Acidity } \\
(\mathrm{mg} / \mathrm{L})\end{array}$ \\
\hline 2000 & 124 & 4 & 1616 \\
\hline 2001 & 119 & 5 & 1515 \\
\hline 2002 & 132 & 4 & 945 \\
\hline 2003 & 179 & 8 & 1069 \\
\hline Season & $\begin{array}{c}\text { Avg Precip per Season } \\
(\mathrm{cm})\end{array}$ & $\begin{array}{l}\text { Average Flow } \\
(\mathrm{L} / \mathrm{s})\end{array}$ & $\begin{array}{c}\text { Average Acidity } \\
(\mathrm{mg} / \mathrm{L})\end{array}$ \\
\hline Summer & 48 & 5 & 1256 \\
\hline Fall & 31 & 2 & 1317 \\
\hline Winter & 26 & 6 & 1206 \\
\hline Spring & 34 & 8 & 1383 \\
\hline Flow Category & $\begin{array}{c}\text { Avg Precip per day } \\
(\mathrm{cm})\end{array}$ & $\begin{array}{c}\text { Average Flow } \\
(\mathrm{L} / \mathrm{s})\end{array}$ & $\begin{array}{c}\text { Average Acidity } \\
(\mathrm{mg} / \mathrm{L})\end{array}$ \\
\hline Low & 0.3 & 2 & 1518 \\
\hline Mid & 0.5 & 5 & 1157 \\
\hline High & 0.4 & 10 & 1221 \\
\hline
\end{tabular}


Table 4-8: Flow rates and acidity amounts at the T\&T mine by rainfall event

Flow rates and acidity amounts at the T\&T mine following dry periods of no rain along with high rainfall events. Seasonal averages of acidity are Summer $=813 \mathrm{mg} / \mathrm{L}$, Fall $=236 \mathrm{mg} / \mathrm{L}$, Winter $=483 \mathrm{mg} / \mathrm{L}$, and Spring $=712 \mathrm{mg} / \mathrm{L}$.

\begin{tabular}{lllccc}
\hline \multirow{5}{*}{ Winter } & Date of Sampling & $\begin{array}{c}\text { Days Since } \\
\text { Precipitation } \\
\text { Event }\end{array}$ & $\begin{array}{c}\text { Precipitation } \\
\text { (cm) }\end{array}$ & $\begin{array}{c}\text { Flow } \\
\text { (L/s) }\end{array}$ & $\begin{array}{c}\text { Acidity } \\
\text { (mg/L) }\end{array}$ \\
\hline \multirow{5}{*}{ Spring } & 14-Dec-1999 & 4 & 1.8 & 7 & 695 \\
& 29-Jan-1997 & 1 & 1.5 & 34 & 851 \\
& 16-Feb-2000 & 2 & 2.3 & 15 & 1120 \\
& 2-Apr-1997 & 7 & 3.8 & 42 & 766 \\
& 9-Apr-2001 & 2 & 2.1 & 28 & 596 \\
& 1-Apr-2003 & 2 & 1.3 & 46 & 1100 \\
& 15-May-1996 & 6 & 1.5 & 64 & 3580 \\
& & & & & \\
& 26-Jun-1996 & 1 & 3.8 & 33 & 997 \\
& 24-Jul-1996 & 5 & 8.6 & 45 & 827 \\
& 2-Jul-1997 & 5 & 6.1 & 29 & 822 \\
& 7-Jul-1998 & 6 & 2.5 & 31 & 636 \\
& 10-Jul-2001 & 4 & 4.3 & 23 & 580 \\
& 1-Jul-2002 & 3 & 2.1 & 21 & 600 \\
& 7-Aug-1996 & 7 & 3.6 & 41 & 912 \\
& 1-Aug-2000 & 7 & 1.8 & 12 & 1250 \\
& & & & & \\
Fall & 23-Oct-1996 & 2 & 2.0 & 27 & 918 \\
& 7-Oct-1998 & 1 & 2.2 & 11 & 664 \\
& 1-Oct-2002 & 4 & 4.03 & 8 & 451 \\
& 12-Nov-1996 & 4 & 1.5 & 34 & 803 \\
& 2-Nov-2002 & 3 & 2.3 & 6 & 440 \\
\hline
\end{tabular}

(continues on next page) 


\begin{tabular}{lllccc}
\hline & Date of Sampling & $\begin{array}{c}\text { Days of } \\
\text { 0 Precip }\end{array}$ & $\begin{array}{c}\text { Precipitation } \\
\text { (cm) }\end{array}$ & $\begin{array}{c}\text { Flow } \\
(\mathbf{L} / \mathbf{s})\end{array}$ & $\begin{array}{c}\text { Acidity } \\
\text { (mg/L) }\end{array}$ \\
\hline \multirow{3}{*}{ Winter } & 18-Dec-1996 & 3 & 0 & 21 & 1090 \\
& 22-Jan-1997 & 3 & 0 & 34 & 571 \\
\multirow{5}{*}{ Spring } & 8-Mar-2000 & 5 & 0 & 18 & 1080 \\
& 22-May-1996 & 3 & 0 & 72 & 3310 \\
& 4-May-1999 & 7 & 0 & 19 & 624 \\
& 10-May-2000 & 4 & 0 & 22 & 623 \\
\multirow{5}{*}{ Summer } & & & & & \\
& 5-Jun-1996 & 5 & 0 & 67 & 1110 \\
& 2-Jun-1999 & 7 & 0 & 13 & 592 \\
& 2-Jul-1997 & 4 & 0 & 29 & 822 \\
& 10-Jul-2000 & 4 & 0 & 11 & 1070 \\
& 7-Aug-1996 & 4 & 0 & 41 & 912 \\
& 7-Aug-1998 & 6 & 0 & 23 & 624 \\
& 8-Aug-2001 & 3 & 0 & 13 & 497 \\
& & & & & \\
\multirow{5}{*}{ Fall } & 2-Sep-1997 & 7 & 0 & 18 & 779 \\
& 14-Sep-1999 & 3 & 0 & 6 & 685 \\
& 2-Sep-2002 & 3 & 0 & 6 & 690 \\
& 4-Nov-1996 & 5 & 0 & 33 & 1820 \\
& 7-Nov-2001 & 3 & 0 & 5 & 696 \\
\hline
\end{tabular}


Table 4-9: Flow rates and acidity amounts at the Omega mine following dry periods of no rain along with high rainfall events.

Seasonal averages of acidity are Summer $=1256 \mathrm{mg} / \mathrm{L}$, Fall $=1317 \mathrm{mg} / \mathrm{L}$, Winter $=1206 \mathrm{mg} / \mathrm{L}$, and Spring $=1383 \mathrm{mg} / \mathrm{L}$.

\begin{tabular}{|c|c|c|c|c|c|}
\hline & $\begin{array}{c}\text { Date of } \\
\text { Sampling } \\
\end{array}$ & $\begin{array}{c}\text { Days Since } \\
\text { Precipitation Event } \\
\end{array}$ & $\begin{array}{c}\begin{array}{c}\text { Precipitation } \\
(\mathbf{c m})\end{array} \\
\end{array}$ & $\begin{array}{l}\text { Flow } \\
(\mathbf{L} / \mathbf{s}) \\
\end{array}$ & $\begin{array}{r}\text { Acidity } \\
(\mathrm{mg} / \mathrm{L}) \\
\end{array}$ \\
\hline \multirow[t]{4}{*}{ Winter } & 15-Dec-2000 & 1 & 2.4 & 1.7 & 1580 \\
\hline & 15-Dec-2002 & 1 & 1.8 & 4.7 & 440 \\
\hline & 16-Jan-2002 & 5 & 1.8 & 3.7 & 590 \\
\hline & 24-Feb-2003 & 1 & 2.4 & 18.2 & 780 \\
\hline \multirow[t]{3}{*}{ Spring } & 14-Apr-2000 & 5 & 1.6 & 13.2 & 1880 \\
\hline & 16-Apr-2001 & 4 & 1.4 & 13.2 & 1000 \\
\hline & 15-Apr-2002 & 1 & 2.3 & 10.3 & 780 \\
\hline \multirow[t]{5}{*}{ Summer } & 15-Jun-2000 & 7 & 1.9 & 5.2 & 1050 \\
\hline & 18-Jun-2001 & 1 & 1.9 & 4.3 & 1580 \\
\hline & 17-Jun-2003 & 2 & 3.2 & 12.1 & 440 \\
\hline & 15-Aug-2001 & 2 & 2.5 & 2.4 & 1580 \\
\hline & 13-Aug-2003 & 4 & 1.7 & 3.7 & 1320 \\
\hline \multirow[t]{3}{*}{ Fall } & 15-Nov-2000 & 5 & 2.9 & 1.1 & 1680 \\
\hline & 18-Nov-2003 & 6 & 5.2 & 5.9 & 440 \\
\hline & $\begin{array}{c}\text { Date of } \\
\text { Sampling }\end{array}$ & $\begin{array}{c}\text { Days of no } \\
\text { precipitation }\end{array}$ & $\begin{array}{l}\text { Precipitation } \\
\text { (cm) }\end{array}$ & $\begin{array}{l}\text { Flow } \\
(\mathrm{L} / \mathrm{s})\end{array}$ & $\begin{array}{l}\text { Acidity } \\
(\mathrm{mg} / \mathrm{L})\end{array}$ \\
\hline \multirow[t]{2}{*}{ Winter } & 15-Jan-2001 & 4 & 0 & 1.5 & 1730 \\
\hline & 9-Feb-2000 & 3 & 0 & 1.4 & 2230 \\
\hline \multirow[t]{2}{*}{ Spring } & 15-Mar-2002 & 7 & 0 & 3.5 & 1040 \\
\hline & 15-Mar-2003 & 3 & 0 & 7.0 & 1510 \\
\hline \multirow[t]{2}{*}{ Summer } & 15-Jul-2001 & 3 & 0 & 5.5 & 1410 \\
\hline & 12-Aug-2002 & 5 & 0 & 1.8 & 1300 \\
\hline \multirow[t]{3}{*}{ Fall } & 13-Oct-2003 & 7 & 0 & 3.3 & 1200 \\
\hline & 15-Nov-2001 & 7 & 0 & 1.1 & 1460 \\
\hline & 18-Nov-2003 & 4 & 0 & 5.9 & 440 \\
\hline
\end{tabular}




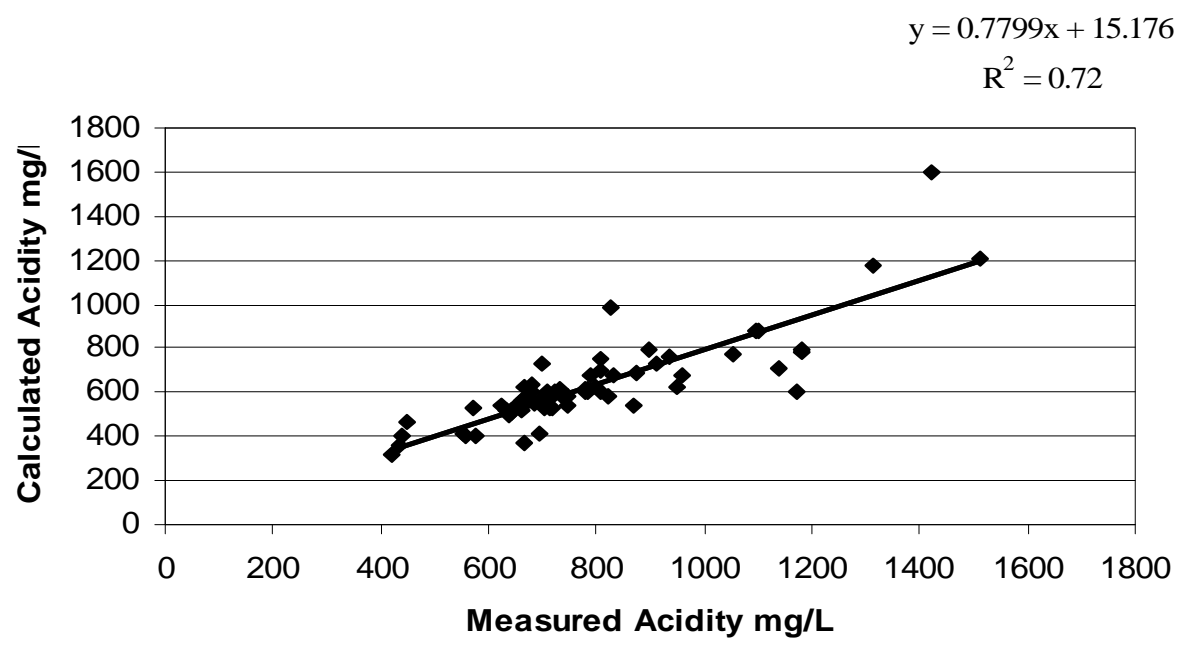

Figure 4-1: Regression analysis of the measured and calculated acidity at the T\&T mine site.

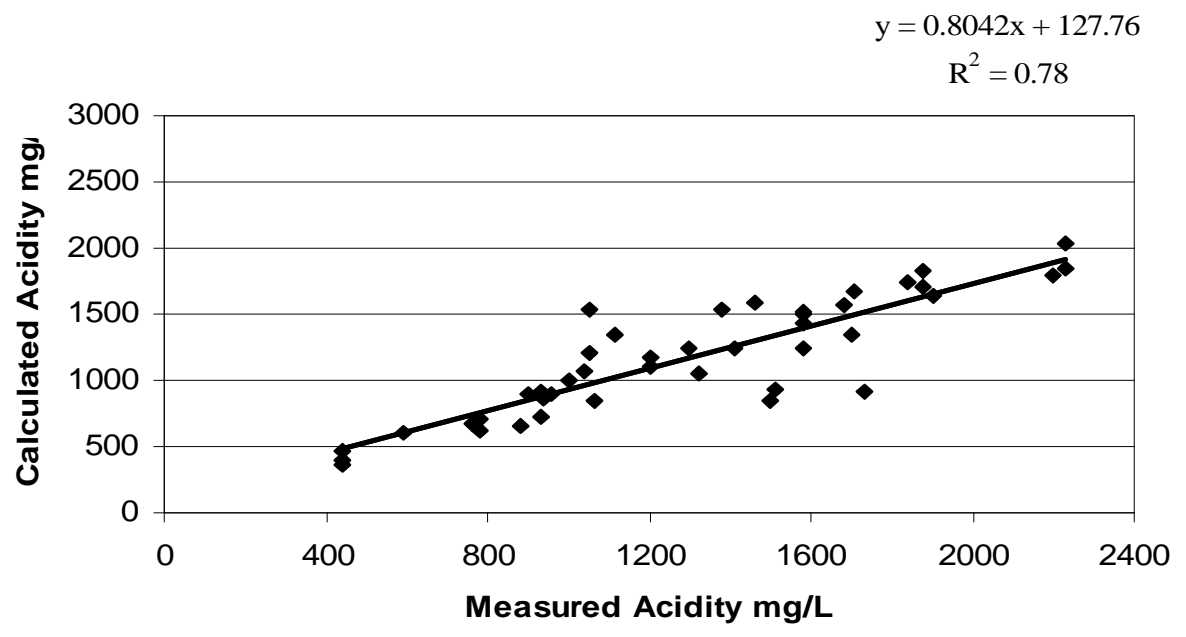

Figure 4-2: Regression analysis of the measured and calculated acidity at the Omega mine site. 


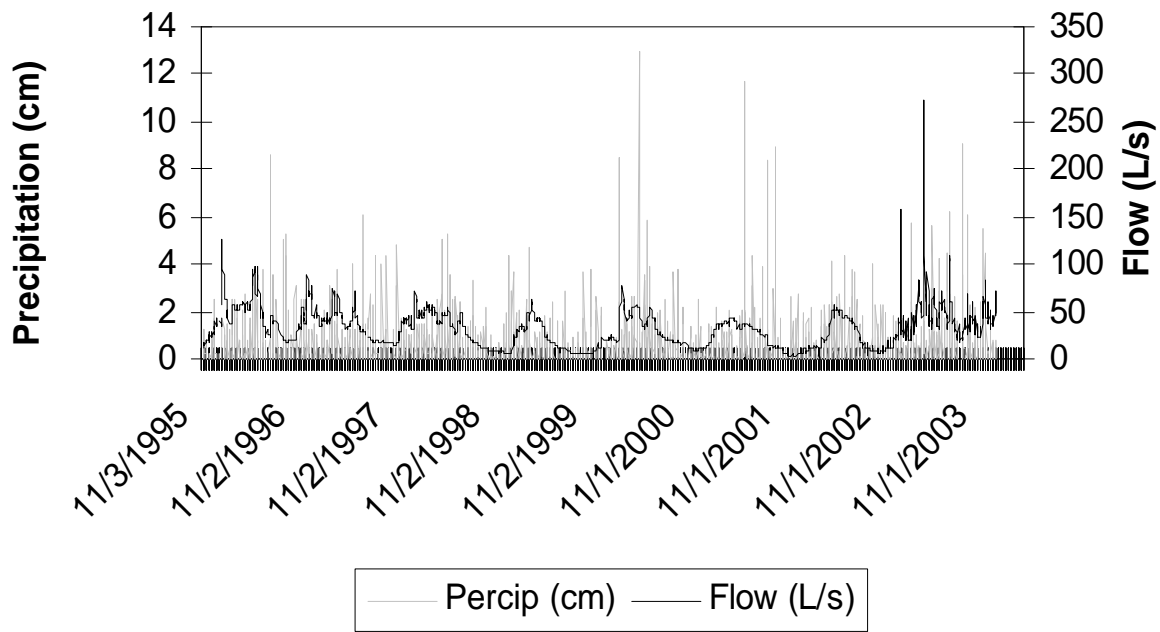

Figure 4-3: Daily flow and precipitation at the T\&T mine site from 10 Nov 1995 to 31 Dec 2003.

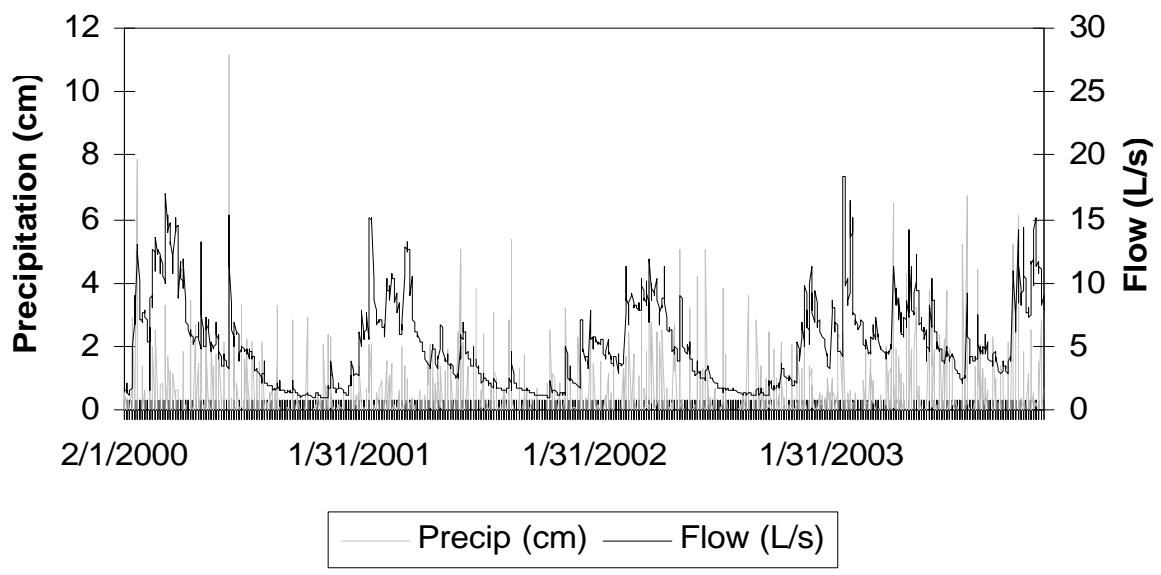

Figure 4-4: Daily flow and precipitation at the Omega mine site from 1 Feb 2000 through 31 Dec 2003. 


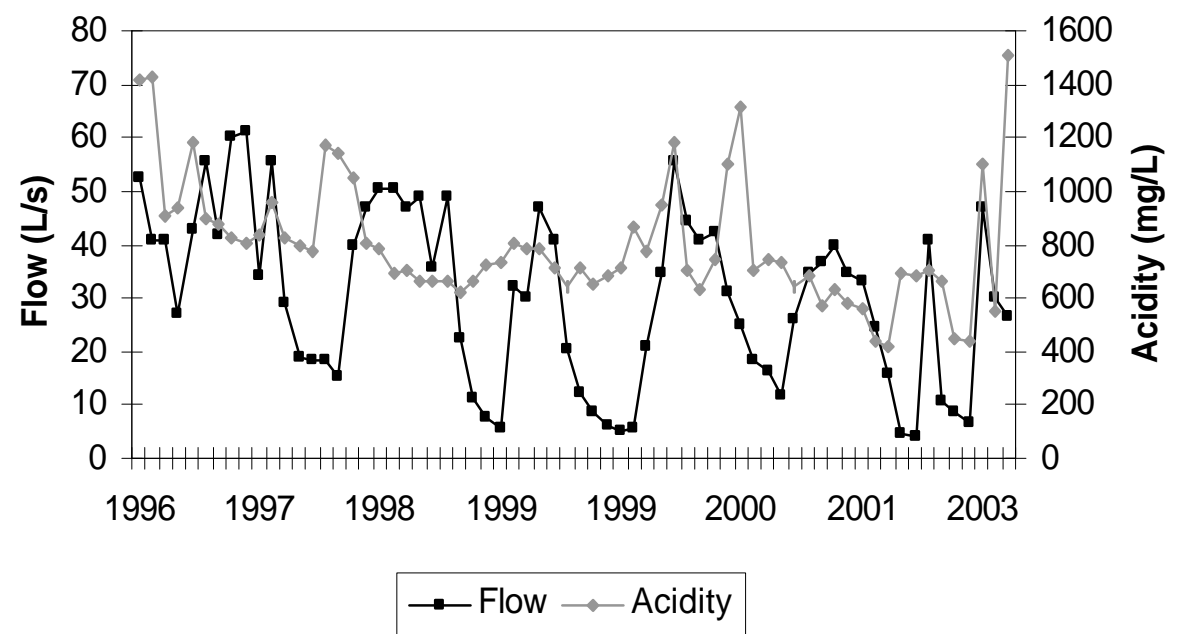

Figure 4-5: Acidity concentrations and flow plotted over time at the T\&T mine site using monthly averages.

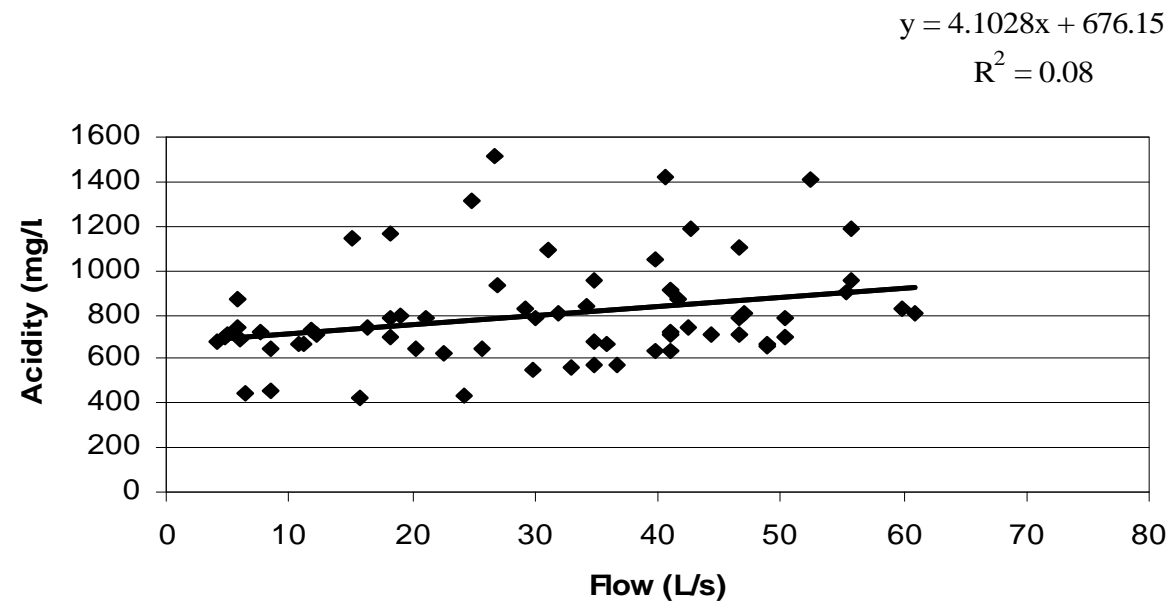

Figure 4-6: Regression analysis of flow and acidity concentration at the T\&T mine site. 


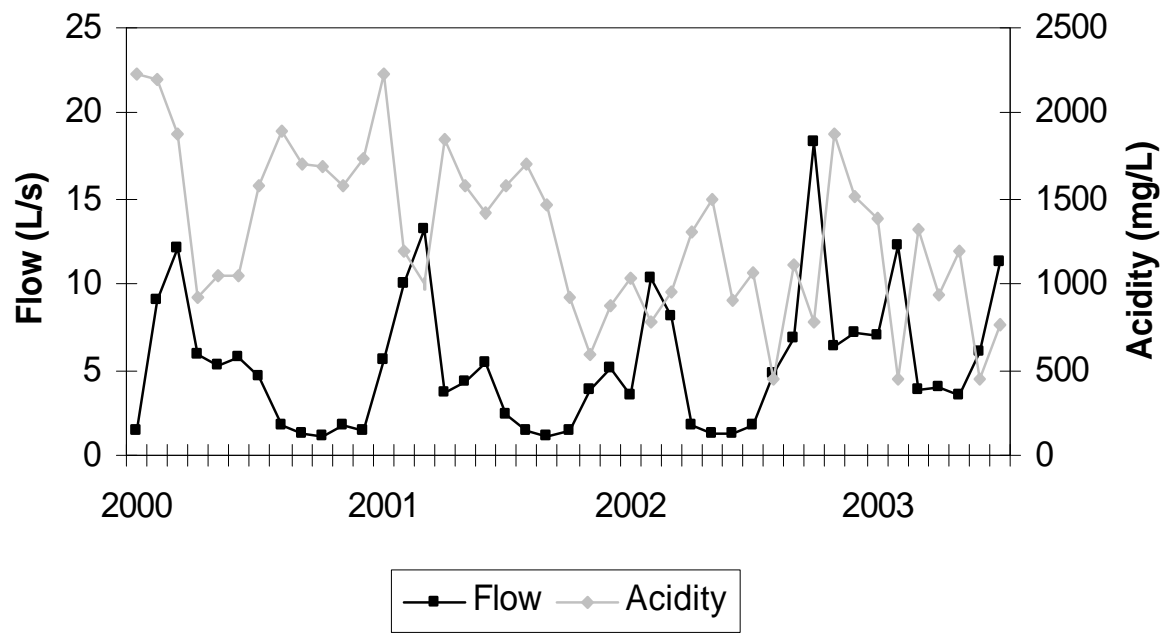

Figure 4-7: Acidity concentrations and flow plotted over time at the Omega mine site using monthly averages.

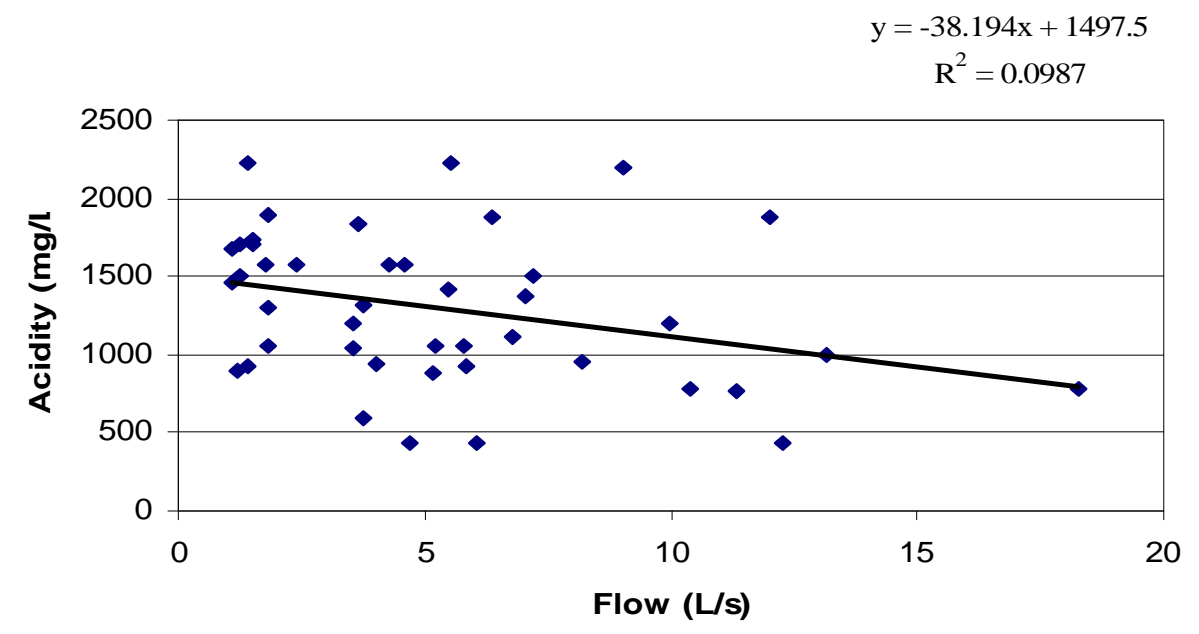

Figure 4-8: Regression analysis of flow and acidity concentration at the Omega mine site. 


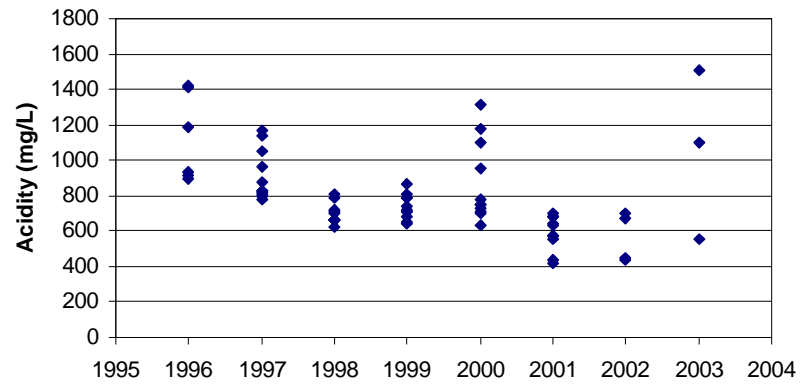

Figure 4-9: Acidity concentration from 1995 through 2003 years at the $T \& T$ mine site.

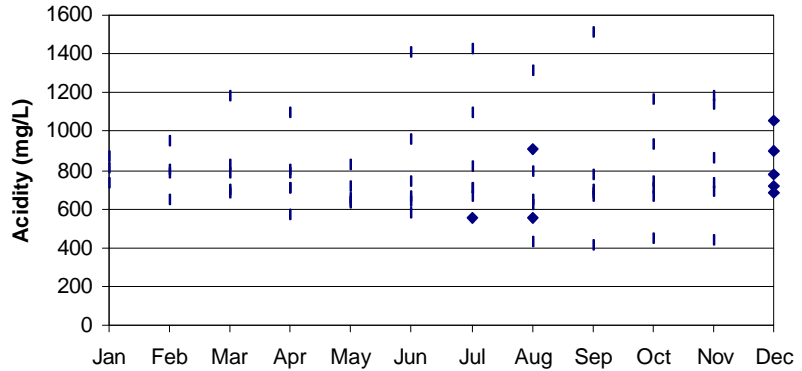

Figure 4-11: Acidity concentrations over months (January to December) at the $T \& T$ mine site.

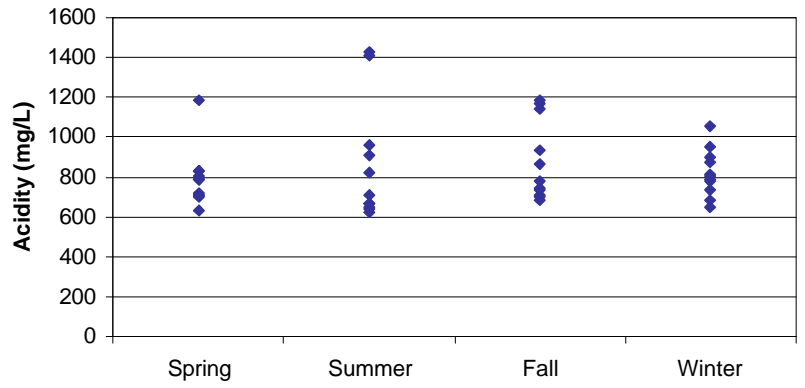

Figure 4-10: Acidity concentration over seasons at the T\&T mine site.

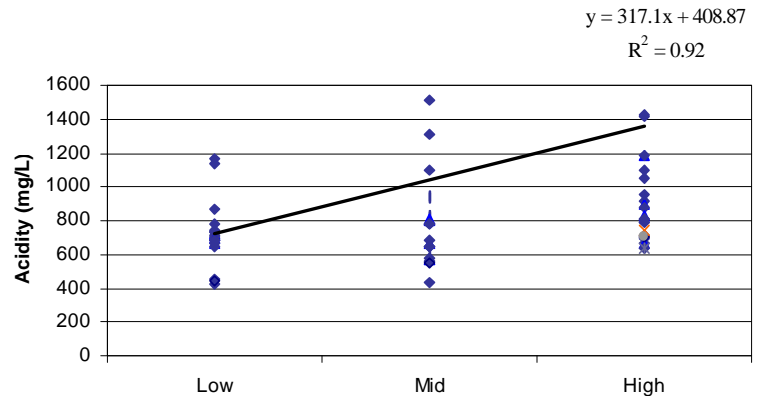

Figure 4-12: Acidity concentrations over flow categories (Low, Mid, and High) with a trend line and regression shown at the $T \& T$ mine site. 


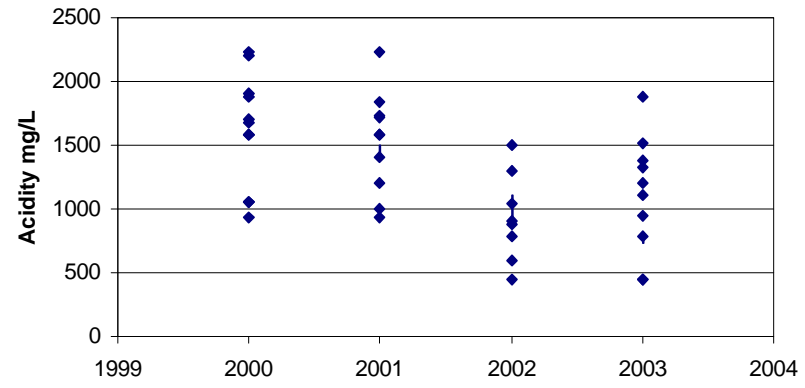

Figure 4-13: Acidity concentration from 1995 through 2003 years at the Omega mine site.

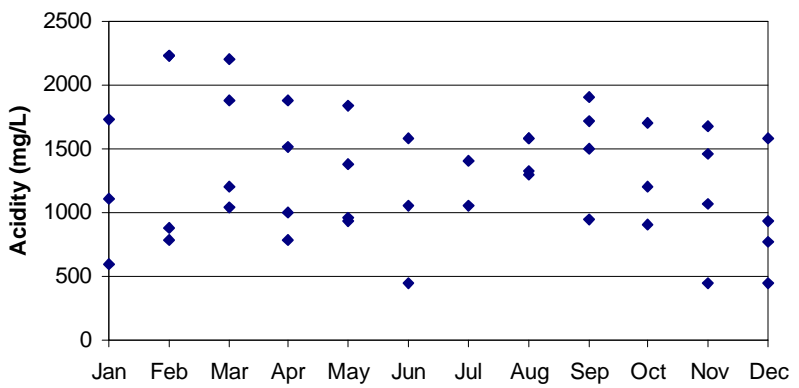

Figure 4-15: Acidity concentrations over months (January to December) at the T\&T mine site.

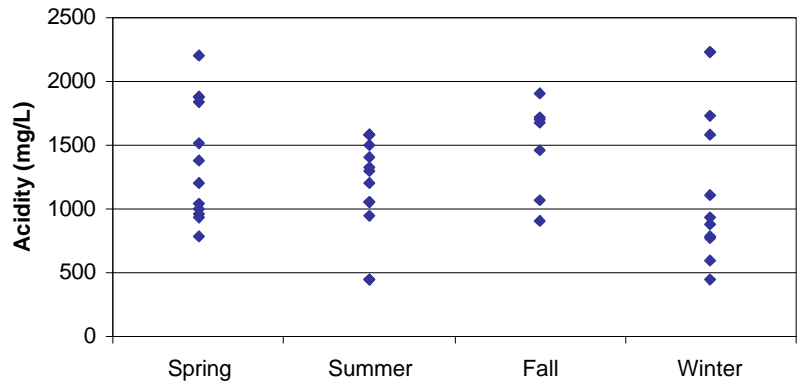

Figure 4-14: Acidity concentration over seasons at the Omega mine site.

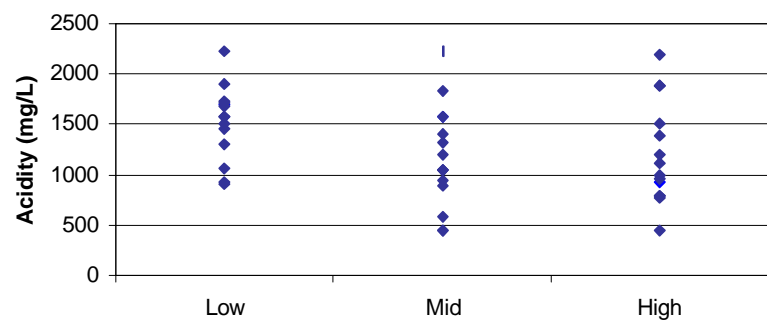

Figure 4-16: Acidity concentrations over flow categories (Low, Mid, and High) at the Omega mine site. 


\section{CHAPTER 5: DISSERTATION SUMMARY}

The first objective of this research was to determine water quality changes from underground mines over a 30-year period and the second objective was to assess the relationship between discharge rates and acidity concentrations emanating from two underground mines.

A research project was initiated in 1968 which identified and sampled over 150 underground mine discharges in the northern West Virginia coal region. Most of these discharges were coming from unflooded, above-drainage underground mines in the Upper Freeport and Pittsburgh coal seams. The sites were revisited in 1999 and 2000, AND Water samples were collected and analyzed from about 75 of the same discharge points. Based on the completeness of the 1968 data, 44 were chosen for further analysis. Twenty of these 44 sites had been sampled and the water analyzed in 1980, which provided an intermediate sampling time to assess water acidity and iron concentrations from the mine.

In order to meet the second objective data sets for T\&T and Omega were gathered through the WVDEP. These data sets were fairly complete in their daily precipitation and flow measurements, along with biweekly water quality analysis. The data sets were used to assess the relationships of precipitation, flow rates, and acidity concentrations.

The foremost conclusion reached is that the majority (34 of 44 sites or 77\%) of abovedrainage underground mines showed significant improvement in acidity over time, and this is good news for watersheds with numerous underground mine discharges. This information can be used practically when developing restoration plans for a watershed and designing conceptual treatment for a particular discharge. By knowing that water quality will improve over time, it will allow for a better understanding of the necessary long term treatment of a particular discharge and the subsequent effect on the watershed. A 50 to $80 \%$ reduction in acidity, iron, and sulfate was found for these mines in northern West Virginia between 1968 and 2000. Of the twenty mines which had measurements of water quality in 1980, five showed that much of the improvement in water chemistry occurred between 1968 and 1980, while 10 others improved more linearly through 2000. However, five of the sites actually showed increased acidity over time. This is evidence that all mines will not behave the same, and widespread conclusions can not be reached. Accurately predicting water quality trends for all above-drainage underground mine sites with time can not be made. 
The factors that appear to complicate our prediction capacity are the ongoing changes in the underground mine including collapse of coal pillars left in the mine to support the roof, the potential for the creation of fresh faces of pyrite that can generate more acid products, ever changing flow paths with blockages and mine pools forming at different places and at different times based on seasonal flow, and variability of oxygen and pyrite within the mine over short distances. Additionally, it appears that coal barriers or seals between mines can leak or completely break thereby allowing additional flow and acidity to be introduced to an adjacent mine. Such factors as these are very difficult to measure and account for in our prediction of mine drainage improvement. However, the overall trends can be used for practical purposes or watershed management with caution.

When assessing the relationship of flow and acidity concentration, no clear conclusion can be made. This is contradictory to ideas that exist (dilution vs. flush) and there is no one idea that can be used as a sweeping explanation for what is occurring in these above-drainage underground mines. As with changes over time, there are numerous factors that can affect the water quality emanating from the mine at any given time of year. Some may depend on precipitation events or others may depend on flow rates and still others may not be related to these at all.

Assessment shows that the highest flows occurred in the spring, with lows flows in the fall. Individual precipitation events did not appear to directly affect flow, not even on a delayed basis. Acidity, however, does not show similar trends. Omega did show slight evidence for lower flows having higher acidities, while T\&T showed the opposite trend.

Analysis of flow and acidity data from these two mines gave hardly any relationship between flow rates and acidity concentrations. The lessons learned, however, are that generalizations can not be made across all above-drainage mines and additional factors must be analyzed. However, information learned from an individual mine relating the trends of flow to acidity can be used to help in designing treatment systems for remediation of the discharge. By observing seasonal trends or yearly trends, data can be extrapolated to better design the most cost effective treatment system, active or passive.

The results of this study can be used as tools in watershed management. The Appalachian region is plagued by AMD impacted streams and any information that can further the cause of restoration efforts will be welcomed by watershed groups, consultants and government agencies. 
Appendix A

MAPS 


\section{Area Summary}

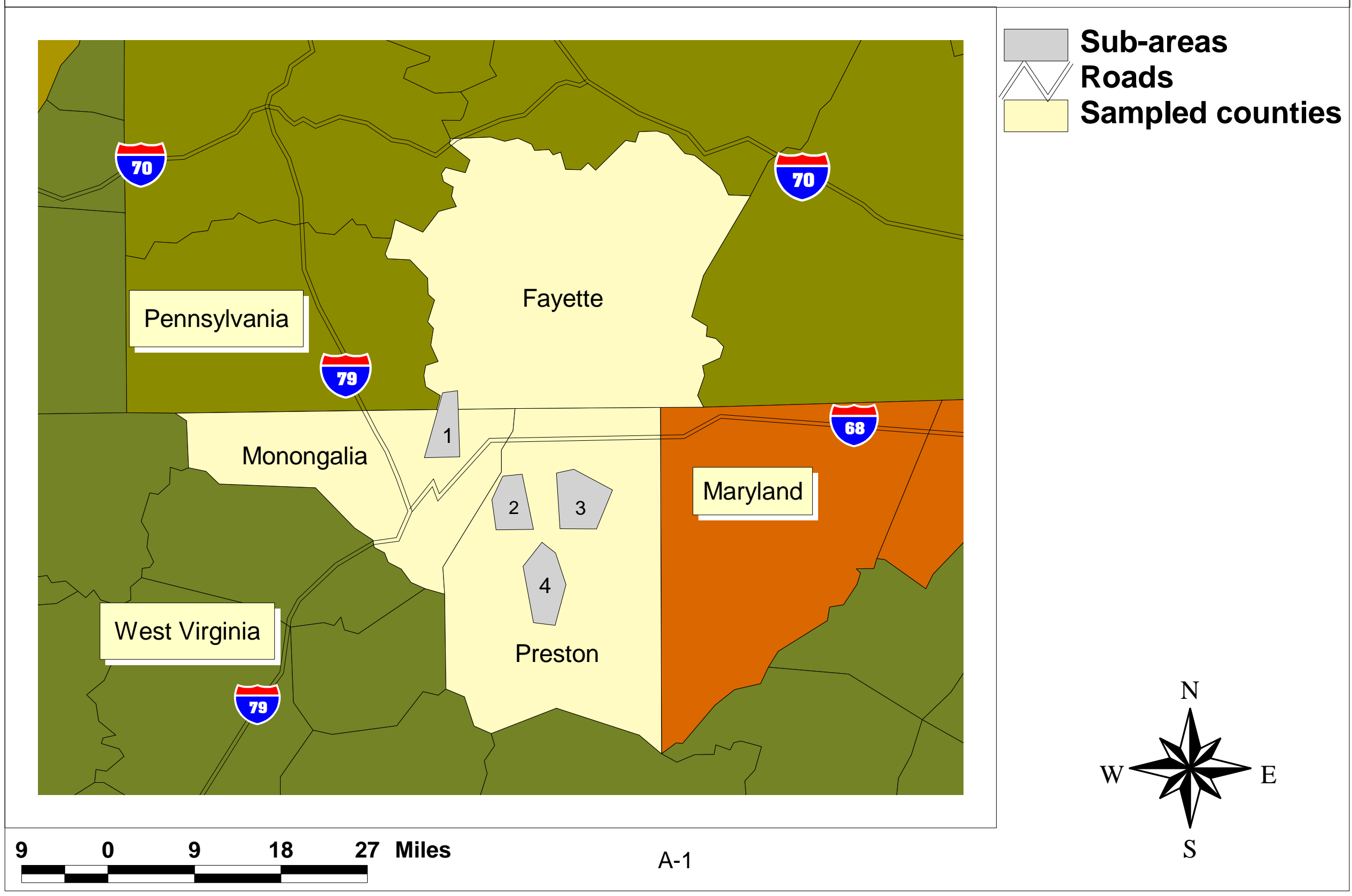




\section{Area 1}

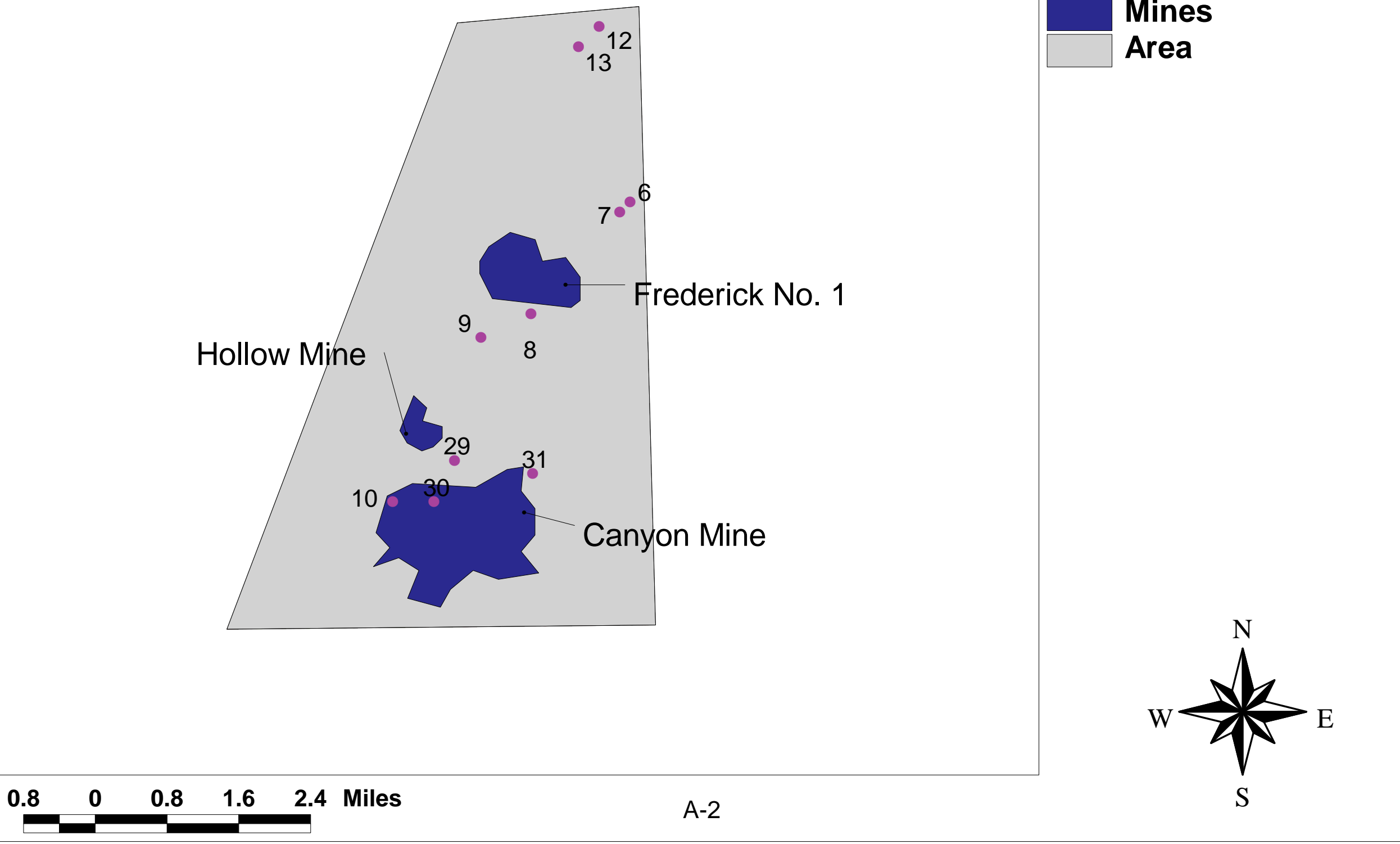




\section{Area 1}

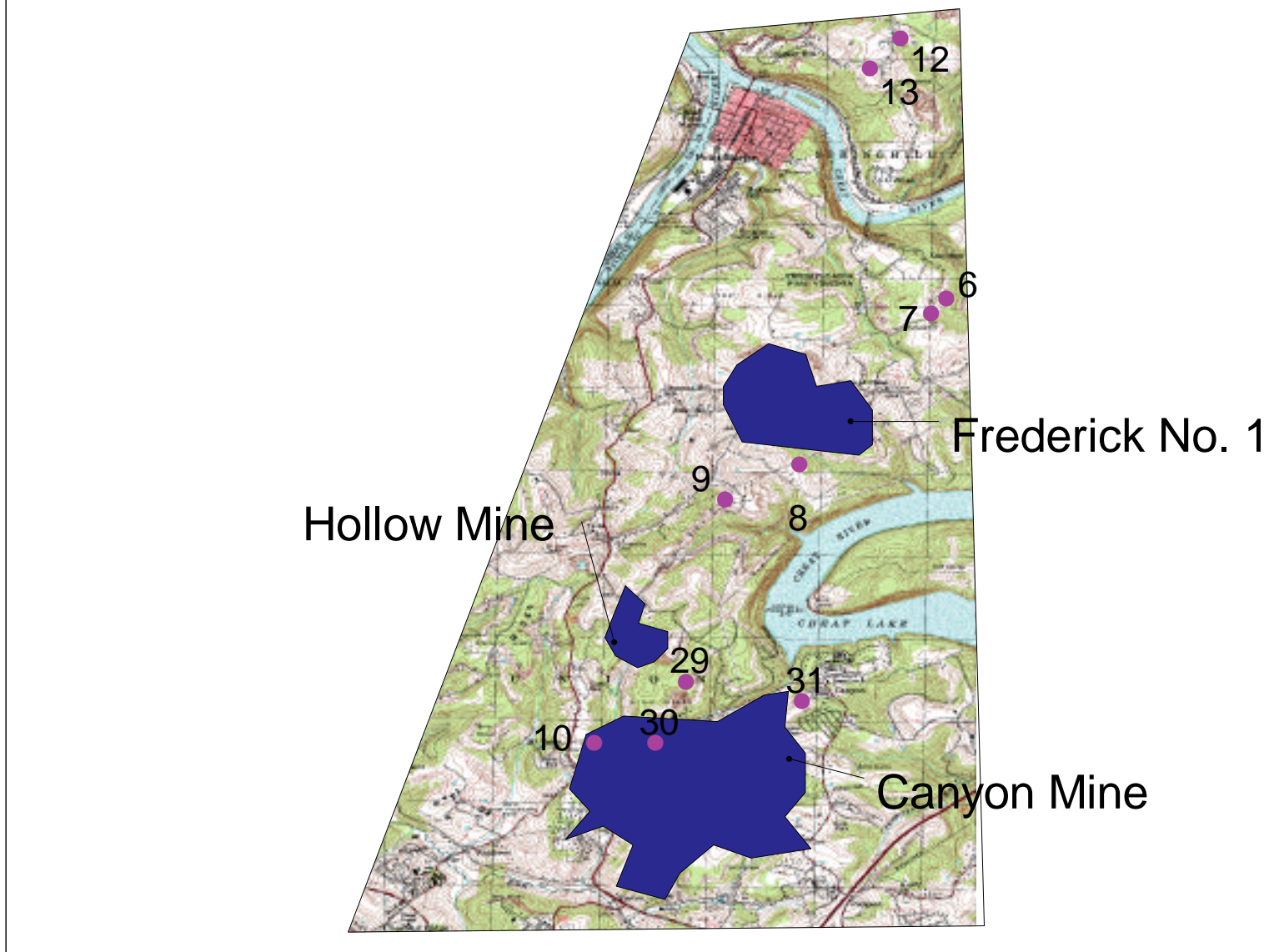

Mines

- Sampled points

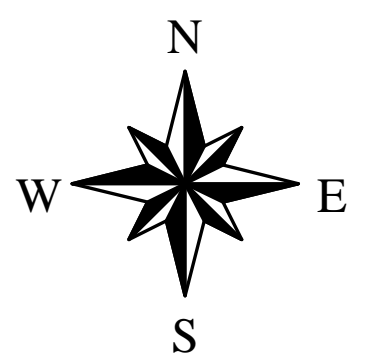




\section{Area 2}

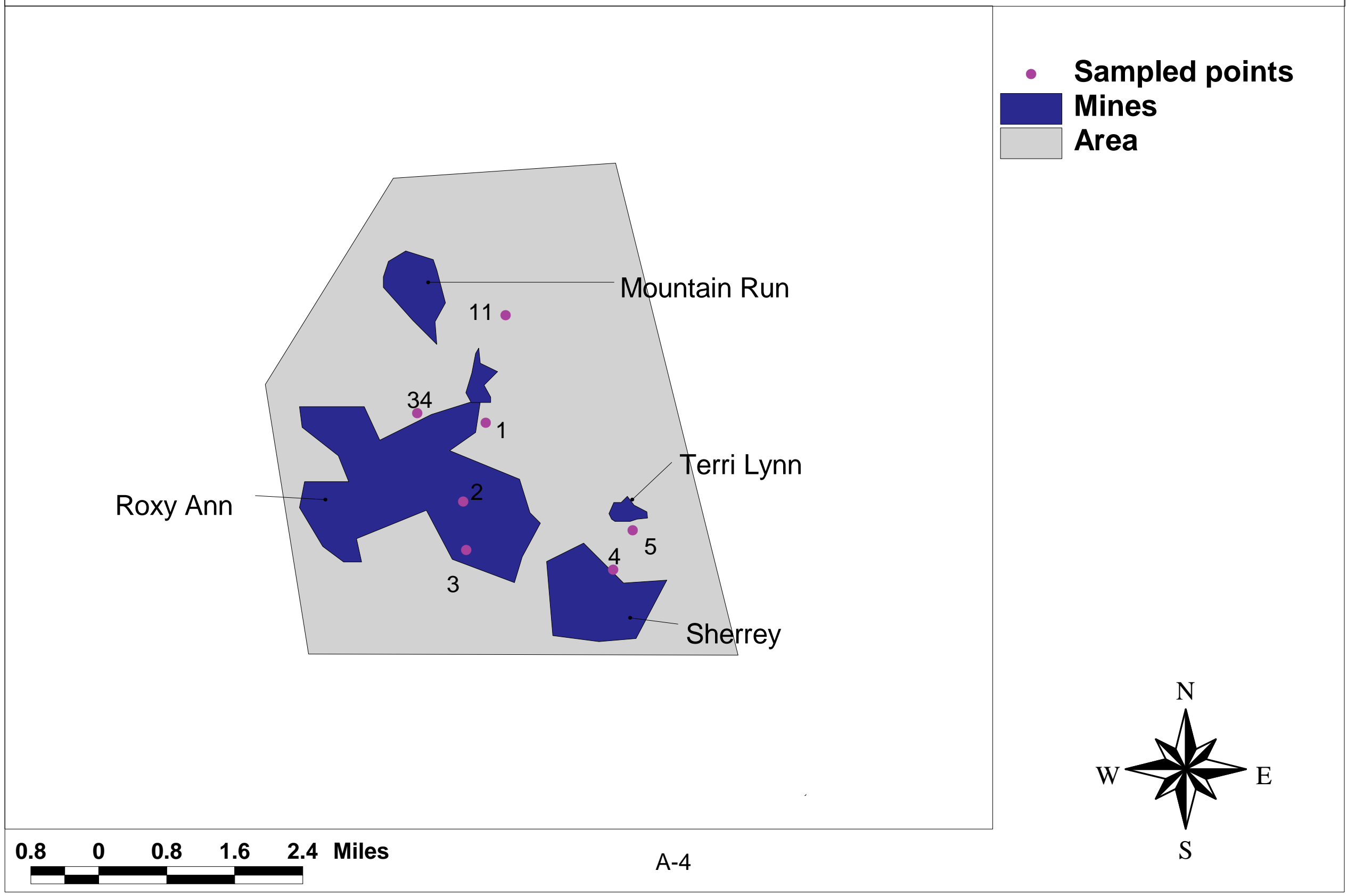




\section{Area 2}

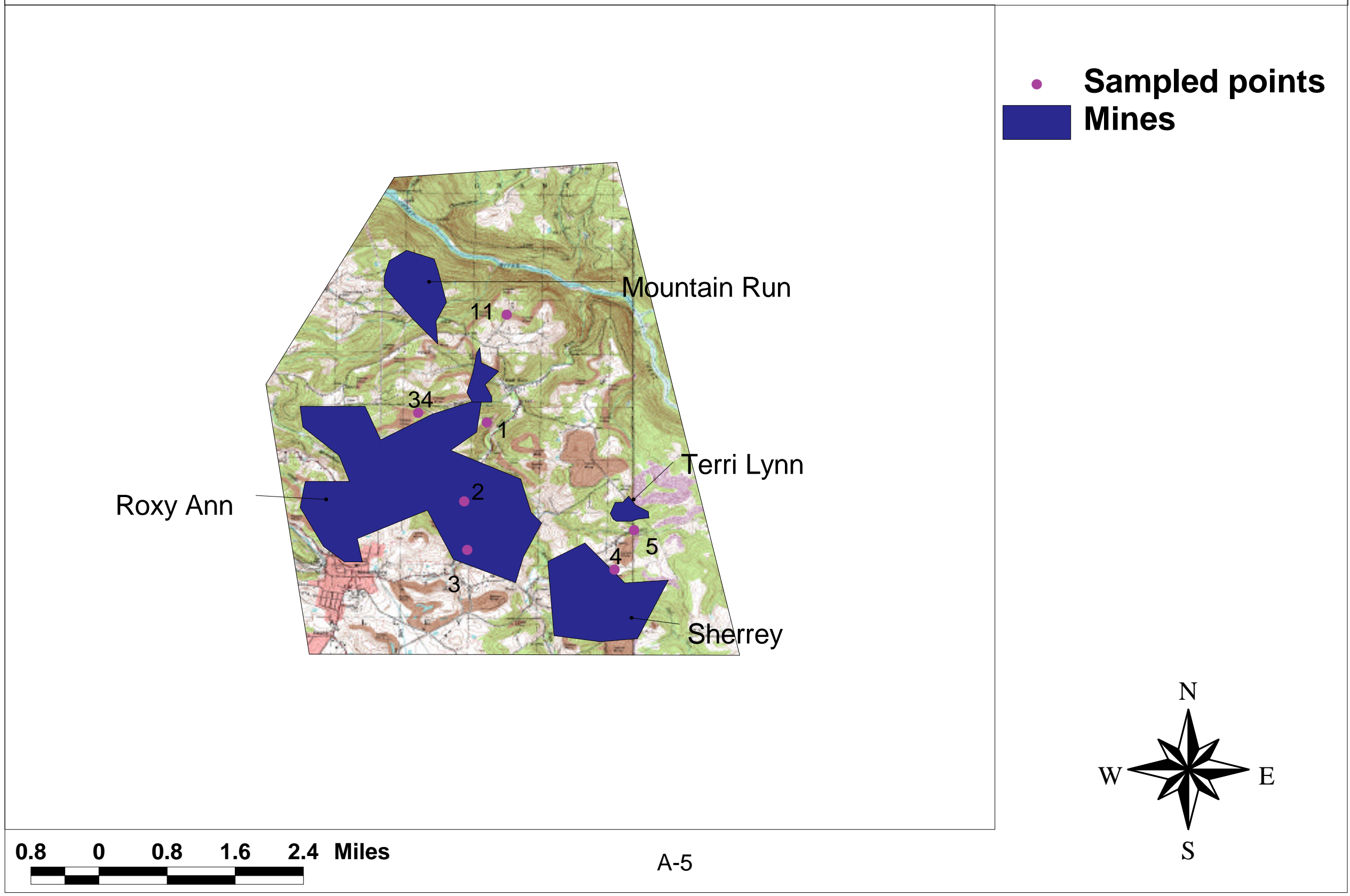




\section{Area 3}

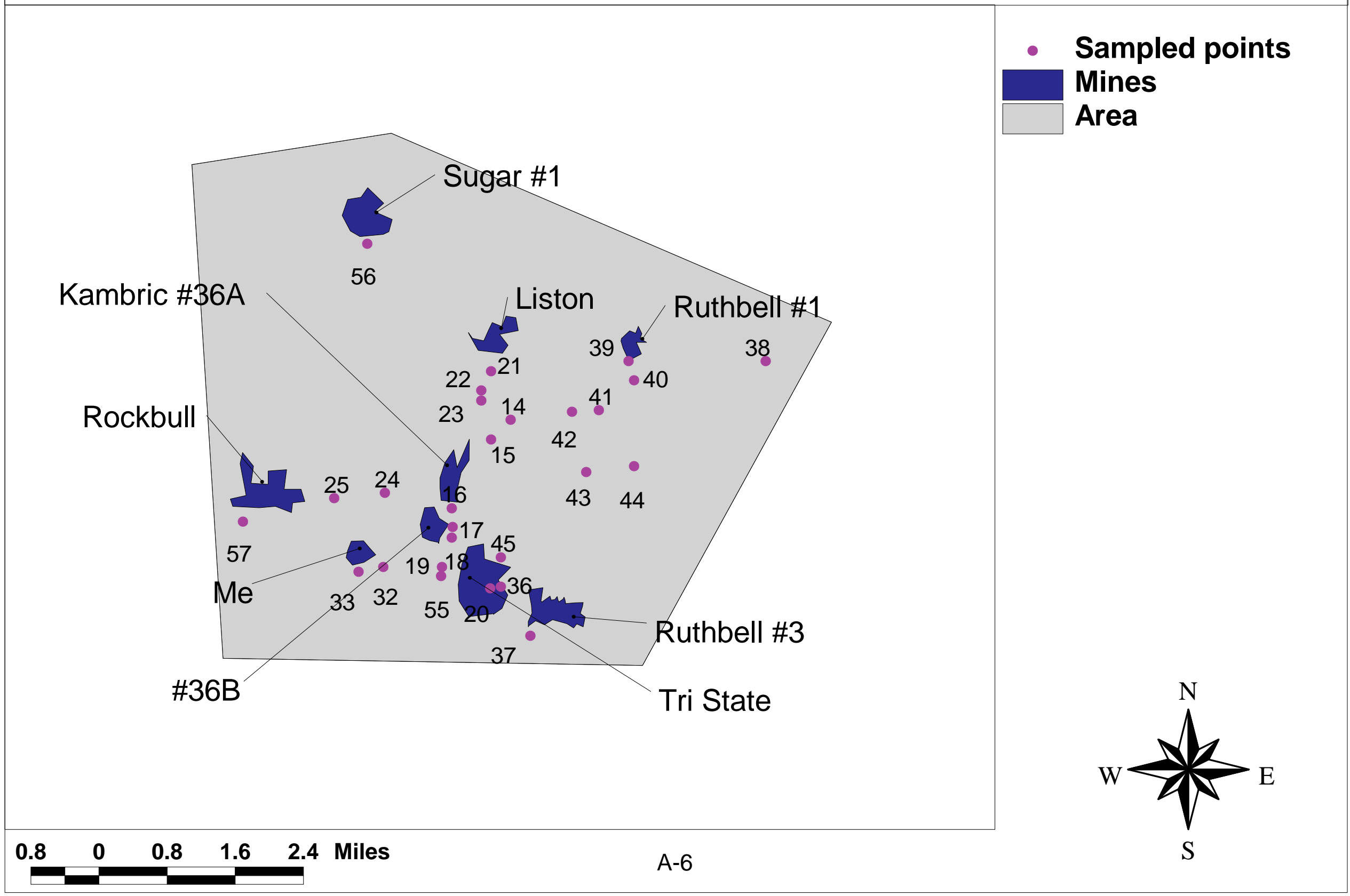




\section{Area 3}

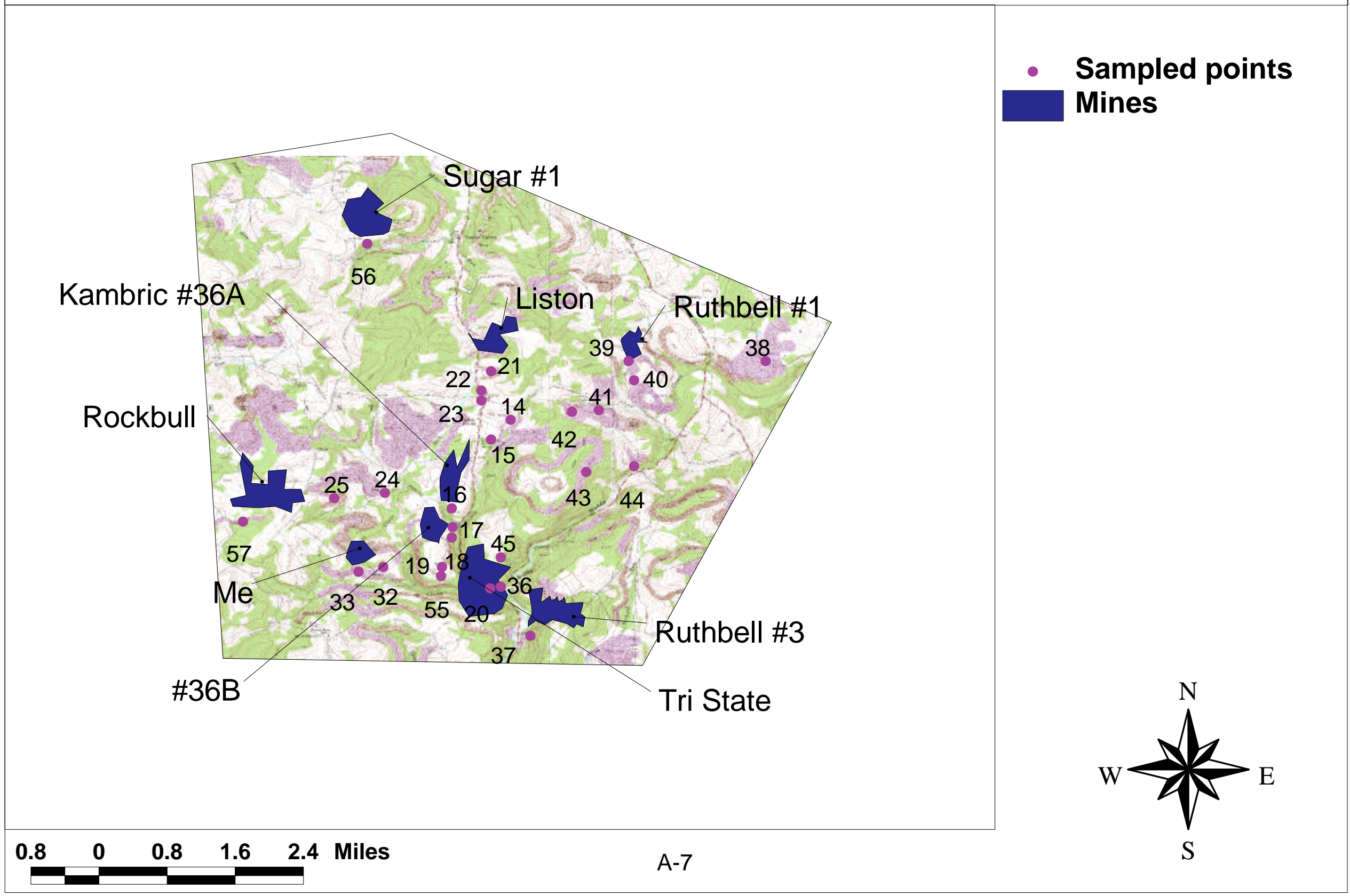




\section{Area 4}

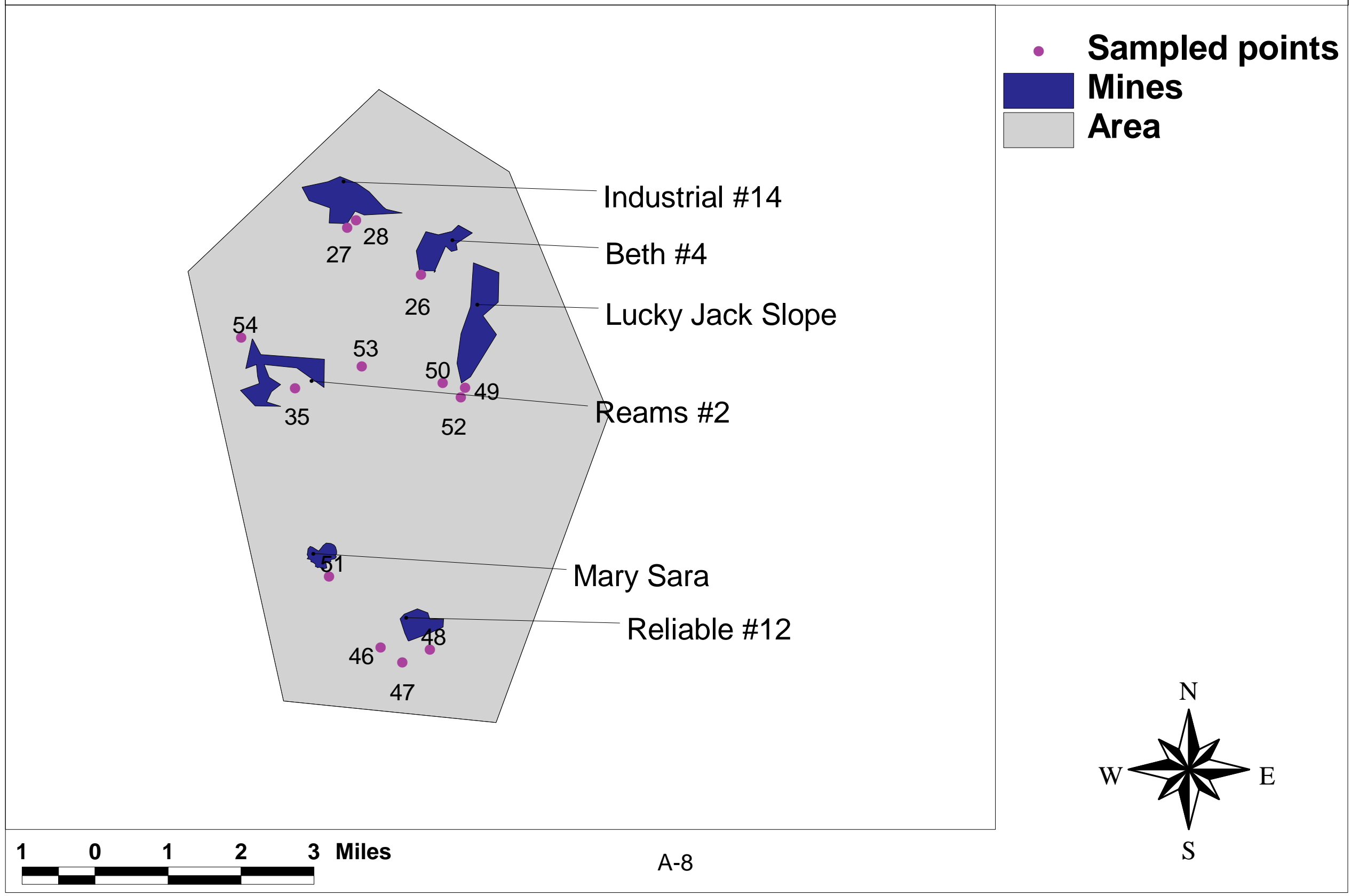




\section{Area 4}

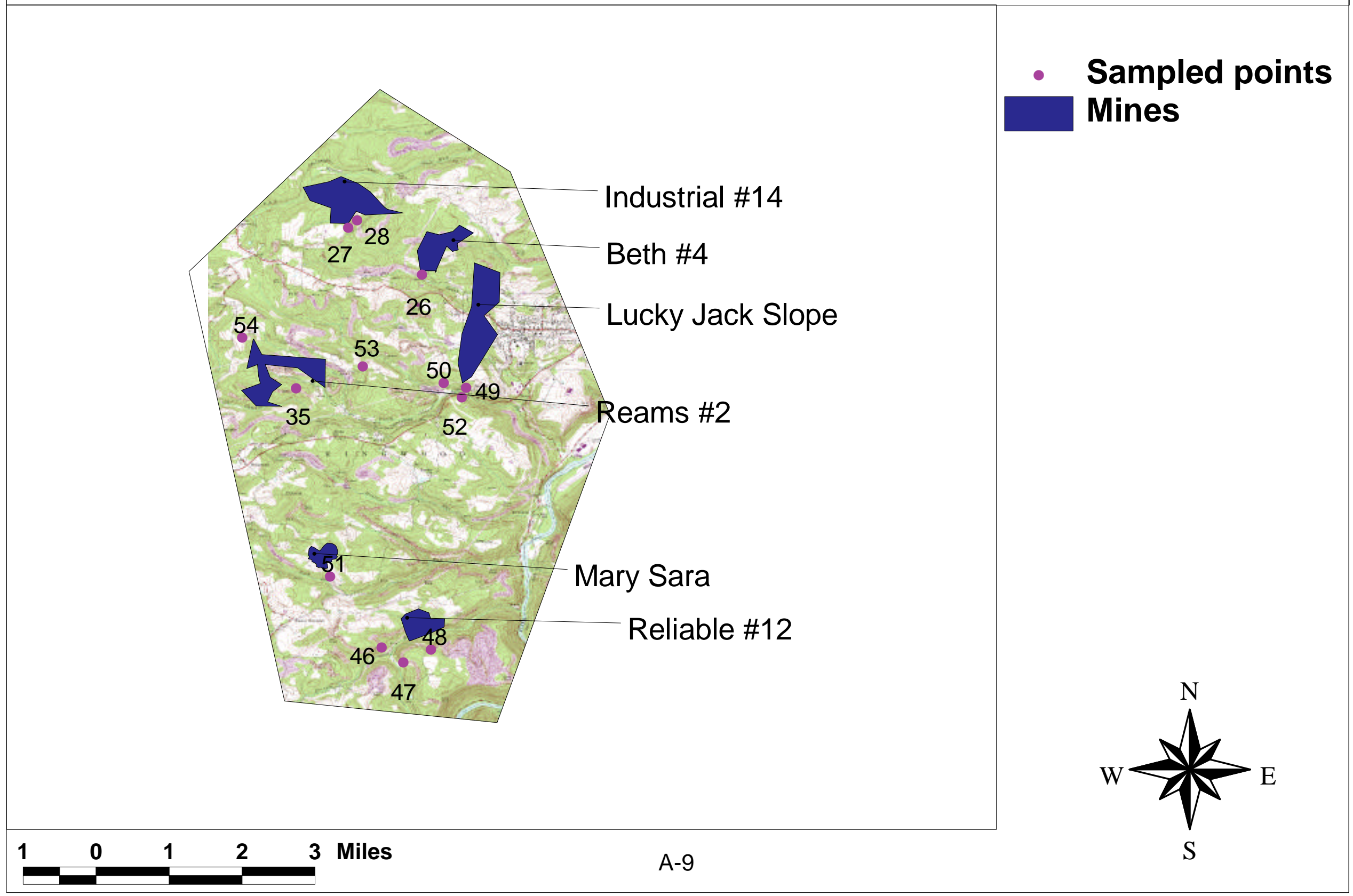




\section{Sampling points}

ID Point name

1 Bull Run 1

2 Bull Run 2

3 Bull Run 3

4 Bull Run 4

5 Bull Run 5

6 Cheat River 1

7 Cheat River 2

8 Cheat River 3

9 Cheat River 4

10 Cheat River 5

11 Cheat River 6

12 Cheat River PA1

13 Cheat River PA2

14 Fickey Run 1

15 Fickey Run 3

16 Fickey Run 5

17 Fickey Run 6

18 Fickey Run 7

19 Fickey Run 8

20 Fickey Run 9

21 Glade Run 1

22 Glade Run 2

23 Glade Run 3

24 Glade Run 4

25 Glade Run 5

26 Green Run 1

27 Green Run 2

28 Green Run 3

29 Lake Lynn 1
ID Point name

30 Lake Lynn 2

31 Lake Lynn 3

32 Martin Creek 2

33 Martin Creek 3

34 Middle River 1

35 Morgan Run 5

36 Muddy Creek 10

37 Muddy Creek 11

38 Muddy Creek 2

39 Muddy Creek 3

$40 \quad$ Muddy Creek 4

41 Muddy Creek 5

42 Muddy Creek 6

43 Muddy Creek 7

44 Muddy Creek 8

45 Muddy Creek 9

46 Pringle Run 3

47 Pringle Run 2

48 Pringle Run 1

49 Morgan Run 1

50 Morgan Run 3

51 Lick Run 1

52 Morgan Run 2

53 Morgan Run 4

54 Morgan Run 6

55 Martin Creek 1

56 Muddy Creek 1

57 Conner Run 1 


\section{Appendix B}

Site Descriptions for Underground Mines 


\begin{tabular}{|c|c|c|c|c|c|c|c|c|}
\hline \multicolumn{2}{|c|}{ Discharge \# } & \multirow{2}{*}{$\begin{array}{l}\text { Mine } \\
\text { Name }\end{array}$} & \multirow{2}{*}{$\begin{array}{l}\text { Mining } \\
\text { Method }\end{array}$} & \multirow[t]{2}{*}{ Category } & \multirow[t]{2}{*}{ Coal Seam } & \multirow{2}{*}{$\begin{array}{c}\text { Lat/Long } \\
\text { (degree,mi } \\
\text { nute) }\end{array}$} & \multirow{2}{*}{$\begin{array}{l}\text { Comments from the } \\
1960 \text { s Study }\end{array}$} & \multirow{2}{*}{$\begin{array}{l}\text { Comments from the } \\
2000 \text { Study }\end{array}$} \\
\hline Old & New & & & & & & & \\
\hline 170190 & Muddy Creek 7 & Cuzzart A & I-Strip & Undisturbed & Bakerstown & $\begin{array}{l}39,34.3^{\prime} \\
79,37.3^{\prime}\end{array}$ & $\begin{array}{l}\text { Kingwood Mining Co., } \\
\text { probably active when } \\
\text { coal mining was good, } \\
\text { numerous auger holes }\end{array}$ & $\begin{array}{l}\text { Numerous benches and } \\
\text { abandoned high walls in } \\
\text { the area, seep comes } \\
\text { directly in the middle of } \\
\text { the piles, no iron floc } \\
\text { visible }\end{array}$ \\
\hline 170210 & Muddy Creek 6 & Cuzzart B & I-Strip & Undisturbed & Upper Freeport & $\begin{array}{l}39,34.7^{\prime} \\
79,36.7\end{array}$ & $\begin{array}{l}\text { Kingwood Mining, very } \\
\text { rough, no regrading }\end{array}$ & $\begin{array}{l}\text { Highwalls, numerous } \\
\text { seeps, and water in } \\
\text { surrounding area, } \\
\text { discharge pops up at } \\
\text { bottom of large rock pile, } \\
\text { flows along bottom of high } \\
\text { wall into large wet area, } \\
\text { large amount of small } \\
\text { particle floc }\end{array}$ \\
\hline 170240 & Muddy Creek 2 & Cuzzart C & A-Strip & Undisturbed & Upper Freeport & $\begin{array}{l}39,35.4^{\prime} \\
79,35.3^{\prime}\end{array}$ & $\begin{array}{l}\text { Kingwood Mining, five } \\
\text { flows }\end{array}$ & $\begin{array}{l}\text { Mine area now a dump, } \\
\text { water seeping out of the } \\
\text { side of a collapsed hill } \\
\text { where the portal was } \\
\text { located, little iron floc }\end{array}$ \\
\hline 170430 & Muddy Creek 4 & Cuzzart D & I-Drift & Disturbed & Upper Freeport & $\begin{array}{l}39,37.4^{\prime} \\
79,34.4^{\prime}\end{array}$ & Guseman Mine & $\begin{array}{l}\text { Both sides of the road } \\
\text { were surface mined, at } \\
\text { bottom of hill is large area } \\
\text { of cattails, red floc where } \\
\text { discharging, emerges } \\
\text { clean at the bottom }\end{array}$ \\
\hline 170440 & Muddy Creek 3 & $\begin{array}{c}\text { Ruthbell } \\
\text { Mg }\end{array}$ & I-Drift & Disturbed & Upper Freeport & $\begin{array}{l}39,35.4^{\prime} \\
79,36.7^{\prime}\end{array}$ & $\begin{array}{l}\text { Assumed closed to allow } \\
\text { for unknown amount of } \\
\text { gob reclamation }\end{array}$ & $\begin{array}{l}\text { Sample collected from } \\
\text { pipe with a filter net, area } \\
\text { covered in gray sand, } \\
\text { discharge flowing out of } \\
\text { spoil, little floc } \\
\text { accumulated on the } \\
\text { bottom }\end{array}$ \\
\hline 170500 & Muddy Creek 1 & Sugar \#1 & I-Strip & Undisturbed & Upper Freeport & $\begin{array}{l}39,35.7^{\prime} \\
79,34.7^{\prime} \\
\end{array}$ & $\begin{array}{l}\text { Flow from backfill, } \\
\text { Kingwood mining }\end{array}$ & No comments \\
\hline
\end{tabular}




\begin{tabular}{|c|c|c|c|c|c|c|c|c|}
\hline \multicolumn{2}{|c|}{ Discharge \# } & \multirow{2}{*}{$\begin{array}{l}\text { Mine } \\
\text { Name }\end{array}$} & \multirow{2}{*}{$\begin{array}{l}\text { Mining } \\
\text { Method }\end{array}$} & \multirow[t]{2}{*}{ Category } & \multirow[t]{2}{*}{ Coal Seam } & \multirow{2}{*}{$\begin{array}{c}\text { Lat/Long } \\
\text { (degree,mi } \\
\text { nute) }\end{array}$} & \multirow{2}{*}{$\begin{array}{l}\text { Comments from the } \\
1960 \text { s Study }\end{array}$} & \multirow{2}{*}{$\begin{array}{l}\text { Comments from the } \\
2000 \text { Study }\end{array}$} \\
\hline Old & New & & & & & & & \\
\hline 170520 & Muddy Creek 5 & Cuzzart E & I-Strip & Undisturbed & Lower Freeport & $\begin{array}{l}39,34.9^{\prime} \\
79,37.0^{\prime}\end{array}$ & $\begin{array}{l}\text { Kingwood Mining Co, } \\
\text { barren, very rough }\end{array}$ & $\begin{array}{l}\text { Small discharge flows into } \\
\text { impoundment into a } \\
\text { beaver dam, little if no flow } \\
\text { pops up out of the ground, } \\
\text { little or no floc }\end{array}$ \\
\hline 170570 & Muddy Creek 8 & Cuzzart F & I-Strip & Undisturbed & Upper Freeport & $\begin{array}{l}39,34.3^{\prime} \\
79,36.6^{\prime}\end{array}$ & $\begin{array}{l}\text { Kingwood Mining Co, } \\
\text { may be reactivated, four } \\
\text { seeps from the spoil }\end{array}$ & $\begin{array}{l}\text { Water appears ponded } \\
\text { among collapsed } \\
\text { sandstone with orange } \\
\text { colorations, no floc visible, } \\
\text { only seep along the } \\
\text { highwall }\end{array}$ \\
\hline 320030 & Cheat River 7 & $\begin{array}{c}\text { Kingwood } \\
\text { C }\end{array}$ & $\overline{--}$ & Disturbed & Upper Freeport & $\overline{--}$ & No comments & \begin{tabular}{|l|} 
Flows over a hilly area, \\
two discharges come \\
together, red stained rocks
\end{tabular} \\
\hline 320120 & Cheat River 8 & $\begin{array}{l}\text { Bellfield } \\
\text { Barnett }\end{array}$ & -- & Undisturbed & Upper Freeport & -- & No comments & $\begin{array}{l}\text { Flows out of collapsed } \\
\text { portal, cows possibly } \\
\text { drinking the water, no floc }\end{array}$ \\
\hline 320240 & Pringle Run 3 & $\begin{array}{c}\text { Kingwood } \\
\text { A }\end{array}$ & $\overline{--}$ & Undisturbed & Upper Freeport & $\overline{--}$ & No comments & $\begin{array}{l}\text { Wooded area, flows out of } \\
\text { collapsed portal, bits of } \\
\text { floc }\end{array}$ \\
\hline 320260 & Pringle Run 2 & $\begin{array}{c}\text { Kingwood } \\
\text { B }\end{array}$ & $\overline{--}$ & Disturbed & Upper Freeport & -- & No comments & $\begin{array}{l}\text { Seepy and flowing into } \\
\text { and out of gob piles, large } \\
\text { wetland, survey } \\
\text { conducted, possible clean- } \\
\text { up, deep red stains }\end{array}$ \\
\hline 320270 & Pringle Run 1 & $\begin{array}{c}\text { Reliable } \\
\# 12\end{array}$ & -- & Undisturbed & Upper Freeport & -- & No comments & $\begin{array}{l}\text { Water comes off of hill in } \\
\text { different places, wetland } \\
\text { area that flows into a } \\
\text { stream, little floc, red } \\
\text { stained rocks }\end{array}$ \\
\hline 320500 & Morgan Run 1 & $\begin{array}{l}\text { Lucky } \\
\text { Jack } \\
\text { Slope }\end{array}$ & -- & Disturbed & Upper Freeport & -- & No comments & $\begin{array}{l}\text { Portal has a pipe directly } \\
\text { into it, bright orange floc }\end{array}$ \\
\hline 320590 & Morgan Run 3 & $\begin{array}{l}\text { Lucky } \\
\text { Jack } \\
\text { Slope }\end{array}$ & -- & Undisturbed & Upper Freeport & -- & No comments & \begin{tabular}{|l|} 
Flows from area above, \\
collapsed portal, flows under \\
road to stream, little to no floc
\end{tabular} \\
\hline
\end{tabular}




\begin{tabular}{|c|c|c|c|c|c|c|c|c|}
\hline \multicolumn{2}{|c|}{ Discharge \# } & \multirow{2}{*}{$\begin{array}{l}\text { Mine } \\
\text { Name }\end{array}$} & \multirow{2}{*}{$\begin{array}{l}\text { Mining } \\
\text { Method }\end{array}$} & \multirow[t]{2}{*}{ Category } & \multirow[t]{2}{*}{ Coal Seam } & \multirow{2}{*}{$\begin{array}{c}\text { Lat/Long } \\
\text { (degree,mi } \\
\text { nute) }\end{array}$} & \multirow{2}{*}{$\begin{array}{l}\text { Comments from the } \\
1960 \text { s Study }\end{array}$} & \multirow{2}{*}{$\begin{array}{l}\text { Comments from the } \\
2000 \text { Study }\end{array}$} \\
\hline Old & New & & & & & & & \\
\hline 320850 & Lick Run 1 & Mary Sara & A-Drift & Disturbed & Upper Freeport & $\begin{array}{l}39,29.2^{\prime} \\
79,42.9^{\prime}\end{array}$ & $\begin{array}{l}\text { Sandy Creek Fuel } \\
\text { Owners, pulling pillars }\end{array}$ & $\begin{array}{l}\text { Discharge pumped into a } \\
\text { limestone channel, the } \\
\text { entire area is surface } \\
\text { disturbed, revegetated, } \\
\text { large limestone boulders } \\
\text { in the stream channel, } \\
\text { highwall channeled, red } \\
\text { stained rocks } \\
\end{array}$ \\
\hline 320980 & Morgan Run 2 & $\begin{array}{c}\text { Kingwood } \\
\text { D }\end{array}$ & -- & Undisturbed & Upper Freeport & -- & No comments & $\begin{array}{l}\text { Flows off hill, piped under } \\
\text { road to degraded stream, } \\
\text { dark purple color }\end{array}$ \\
\hline 321030 & Morgan Run 5 & $\begin{array}{c}\text { Kingwood } \\
E\end{array}$ & -- & Undisturbed & Upper Freeport & -- & No comments & $\begin{array}{l}\text { Portal not affected, water } \\
\text { seeping up to about 20' } \\
\text { from the portal, little floc }\end{array}$ \\
\hline 321090 & Morgan Run 4 & $\begin{array}{l}\text { Lucky } \\
\text { Jack }\end{array}$ & $\overline{--}$ & Undisturbed & Upper Freeport & $\overline{--}$ & No comments & $\begin{array}{l}\text { No flow, water was } \\
\text { collected at the pool in the } \\
\text { portal, could see the } \\
\text { timbers and rails, reddish } \\
\text { color water }\end{array}$ \\
\hline 321250 & Morgan Run 6 & Reams \#2 & -- & Undisturbed & Upper Freeport & -- & No comments & $\begin{array}{l}\text { Discharge in wooded } \\
\text { area, coming from portal } \\
\text { area on hill above, portal } \\
\text { undisturbed, deep purple } \\
\text { water, medium floc }\end{array}$ \\
\hline 321500 & Green Run 1 & Beth \#4 & I-Drift & Undisturbed & Upper Freeport & $\begin{array}{l}32,29.4^{\prime} \\
79,44.0^{\prime}\end{array}$ & Open but dry & $\begin{array}{l}\text { Flows out of old highwall, } \\
\text { flows directly to creek, } \\
\text { little floc }\end{array}$ \\
\hline 321580 & Green Run 2 & $\begin{array}{c}\text { Industrial } \\
\# 14\end{array}$ & I-Strip & Undisturbed & Upper Freeport & $\begin{array}{l}32,29.5^{\prime} \\
79,43.3^{\prime}\end{array}$ & Probably okay & $\begin{array}{l}\text { Impoundment, no visible } \\
\text { flow, orange/red color }\end{array}$ \\
\hline 321600 & Green Run 3 & $\begin{array}{c}\text { Industrial } \\
\# 14\end{array}$ & I-Drift & Disturbed & Upper Freeport & $\begin{array}{l}32,29.6^{\prime} \\
79,43.2^{\prime}\end{array}$ & $\begin{array}{l}\text { Seep from openings } \\
\text { sampled }\end{array}$ & $\begin{array}{l}\text { Two portals approximately } \\
20 \text { ' apart, this one is still } \\
\text { flowing, surface mined } \\
\text { behind }\end{array}$ \\
\hline
\end{tabular}




\begin{tabular}{|c|c|c|c|c|c|c|c|c|}
\hline \multicolumn{2}{|c|}{ Discharge \# } & \multirow{2}{*}{$\begin{array}{l}\text { Mine } \\
\text { Name }\end{array}$} & \multirow{2}{*}{$\begin{array}{l}\text { Mining } \\
\text { Method }\end{array}$} & \multirow[t]{2}{*}{ Category } & \multirow[t]{2}{*}{ Coal Seam } & \multirow{2}{*}{$\begin{array}{c}\text { Lat/Long } \\
\text { (degree,mi } \\
\text { nute) }\end{array}$} & \multirow{2}{*}{$\begin{array}{l}\text { Comments from the } \\
1960 \text { s Study }\end{array}$} & \multirow{2}{*}{$\begin{array}{l}\text { Comments from the } \\
2000 \text { Study }\end{array}$} \\
\hline Old & New & & & & & & & \\
\hline 360870 & Bull Run 4 & Sherrey & I-Drift & Undisturbed & Upper Freeport & $\begin{array}{l}39,33.2^{\prime} \\
79,45.2^{\prime}\end{array}$ & $\begin{array}{l}\text { Old wet farm mines, } \\
\text { owner wants to stay open }\end{array}$ & \begin{tabular}{|l|} 
Free flowing through \\
wooded area, undisturbed \\
area near farms, medium \\
amount of floc with stained \\
rocks
\end{tabular} \\
\hline 361090 & Bull Run 2 & Roxy Ann & I-Drift & Disturbed & Upper Freeport & $\begin{array}{l}39,33.2^{\prime} \\
79,46.7^{\prime}\end{array}$ & Flow from filled openings & $\begin{array}{l}\text { AML site, pipe into the } \\
\text { mine, whole site } \\
\text { vegetated, discharges } \\
\text { down fabric to limestone } \\
\text { ditch, stained rocks }\end{array}$ \\
\hline 361150 & Bull Run 1 & Kimberly & I-Drift & Disturbed & Upper Freeport & $\begin{array}{l}39,34.7^{\prime} \\
79,46.5^{\prime}\end{array}$ & $\begin{array}{l}\text { Drains mine, has } 4 \text { ' deep } \\
\text { trench into one opening }\end{array}$ & \begin{tabular}{|l|} 
Disturbed, revegetated \\
site, discharges at pipe, \\
down rip-rap, deep purple \\
water, medium amount of \\
orange floc
\end{tabular} \\
\hline 361280 & Cheat River 6 & $\begin{array}{l}\text { Mountain } \\
\text { Run }\end{array}$ & $\underset{\quad \text { I-Strip + }}{\text { Drift }}$ & Disturbed & Upper Freeport & $\begin{array}{l}39,35.8^{\prime} \\
79,46.3^{\prime}\end{array}$ & $\begin{array}{l}\text { Two okay portals, strip } \\
\text { needs disturbed }\end{array}$ & $\begin{array}{l}\text { Collapsed area, } \\
\text { impounded water, lots of } \\
\text { deep red/orange floc }\end{array}$ \\
\hline 361320 & Middle River 1 & $\begin{array}{c}\text { Mountain } \\
\text { Run }\end{array}$ & $\begin{array}{c}\text { A-Strip }+ \\
\text { Drift }\end{array}$ & Disturbed & Upper Freeport & $\begin{array}{l}39,34.8^{\prime} \\
79,47.2^{\prime} \\
\end{array}$ & Preston Coal Co. & $\begin{array}{l}\text { Large area discharging, } \\
\text { many portals }\end{array}$ \\
\hline 361370 & Bull River 3 & Roxy Ann & I-Drift & Disturbed & Upper Freeport & $\begin{array}{l}39,33.4^{\prime} \\
79,46.7^{\prime}\end{array}$ & $\begin{array}{l}\text { Subsided flow, good } \\
\text { access }\end{array}$ & $\begin{array}{l}\text { Flows as a small stream, } \\
\text { no floc }\end{array}$ \\
\hline 380220 & Cheat River 5 & $\begin{array}{l}\text { Canyon } \\
\text { Mine }\end{array}$ & I-Drift & Disturbed & Pittsburgh & $\begin{array}{l}39,40.2^{\prime} \\
79,55.0^{\prime}\end{array}$ & $\begin{array}{l}\text { Caved in, Sand Ridge } \\
\text { Coal Co. }\end{array}$ & $\begin{array}{l}\text { Entire hill below cemetery, } \\
\text { highwall remains, runs } \\
\text { along road, cement ditch } \\
\text { to stop erosion, deep red } \\
\text { floc }\end{array}$ \\
\hline 382050 & Lake Lynn 1 & $\begin{array}{l}\text { Hollow } \\
\text { Mine }\end{array}$ & I-Drift & Undisturbed & Pittsburgh & $\begin{array}{l}39,40.6^{\prime} \\
79,54.4^{\prime}\end{array}$ & $\begin{array}{l}\text { Fox Coal Co., } \\
\text { reclamation needed }\end{array}$ & $\begin{array}{l}\text { Runs out of rocks, } \\
\text { collapsed portal, other } \\
\text { areas are dry, garbage } \\
\text { around, little fine brown } \\
\text { granules }\end{array}$ \\
\hline 382120 & Lake Lynn 3 & $\begin{array}{l}\text { Canyon } \\
\text { Mine }\end{array}$ & I-Drift & Disturbed & Pittsburgh & $\begin{array}{l}39,40.9^{\prime} \\
79,53.9^{\prime}\end{array}$ & $\begin{array}{l}\text { Canyon Coal Mine, } \\
\text { sealed stripped out }\end{array}$ & $\begin{array}{l}\text { Area above and around } \\
\text { has been disturbed, } \\
\text { ponded water, no floc }\end{array}$ \\
\hline
\end{tabular}




\begin{tabular}{|c|c|c|c|c|c|c|c|c|}
\hline \multicolumn{2}{|c|}{ Discharge \# } & \multirow{2}{*}{$\begin{array}{l}\text { Mine } \\
\text { Name }\end{array}$} & \multirow{2}{*}{$\begin{array}{l}\text { Mining } \\
\text { Method }\end{array}$} & \multirow[t]{2}{*}{ Category } & \multirow[t]{2}{*}{ Coal Seam } & \multirow{2}{*}{$\begin{array}{c}\text { Lat/Long } \\
\text { (degree,mi } \\
\text { nute) }\end{array}$} & \multirow{2}{*}{$\begin{array}{l}\text { Comments from the } \\
1960 \text { s Study }\end{array}$} & \multirow{2}{*}{$\begin{array}{l}\text { Comments from the } \\
2000 \text { Study }\end{array}$} \\
\hline Old & New & & & & & & & \\
\hline 382150 & Lake Lynn 2 & $\begin{array}{l}\text { Canyon } \\
\text { Mine }\end{array}$ & $\begin{array}{l}\text { I-Drift } \\
\end{array}$ & Disturbed & Pittsburgh & $\begin{array}{l}39,40.2^{\prime} \\
79,54.6^{\prime}\end{array}$ & $\begin{array}{l}\text { Trenched to drain low } \\
\text { spot in the mine }\end{array}$ & $\begin{array}{l}\text { Three discharges from hill } \\
\text { piped, deep red floc }\end{array}$ \\
\hline 382620 & Cheat River 4 & \begin{tabular}{|c|} 
Morganto \\
wn North \\
A
\end{tabular} & I-Drift & Undisturbed & Pittsburgh & $\begin{array}{l}39,41.8^{\prime} \\
79,52.7^{\prime}\end{array}$ & $\begin{array}{l}\text { Lyman mine first, Tate } \\
\text { mine later }\end{array}$ & $\begin{array}{l}\text { Highwall left, little flow, } \\
\text { seepy wet area, little floc }\end{array}$ \\
\hline 383170 & Cheat River 1 & \begin{tabular}{|c|} 
Morganto \\
wn North \\
E
\end{tabular} & I-Strip & Undisturbed & Pittsburgh & $\begin{array}{l}39,43.1^{\prime} \\
79,52.7^{\prime}\end{array}$ & $\begin{array}{l}\text { Much gob in spoil pile of } \\
\text { strip }\end{array}$ & $\begin{array}{l}\text { Seep comes in from rock, } \\
\text { flows along road, sampled } \\
\text { where emerged, little floc }\end{array}$ \\
\hline 383180 & Cheat River 2 & \begin{tabular}{|} 
Morganto \\
wn North \\
D
\end{tabular} & A-Drift & Disturbed & Pittsburgh & $\begin{array}{l}39,43.0^{\prime} \\
79,52.8^{\prime}\end{array}$ & $\begin{array}{l}\text { Ray Chess, may also } \\
\text { pump }\end{array}$ & $\begin{array}{l}\text { Surface mined, pipe must } \\
\text { extend into the mine, } \\
\text { discharging at end of } \\
\text { disturbed area, area } \\
\text { vegetated, large floc } \\
\text { granules }\end{array}$ \\
\hline 383210 & Cheat River PA1 & $\begin{array}{c}\text { Morganto } \\
\text { wn North } \\
\text { B }\end{array}$ & $\begin{array}{c}\text { I-Strip + } \\
\text { Drift }\end{array}$ & Disturbed & Pittsburgh & $\begin{array}{l}39,44.8^{\prime} \\
79,53.0^{\prime}\end{array}$ & $\begin{array}{l}\text { Bertoni and Agelini Coal } \\
\text { Co., no reclamation, } \\
\text { flows from visible } \\
\text { openings, portal under } \\
\text { debris }\end{array}$ & $\begin{array}{l}\text { AML project, disturbed } \\
\text { ditches, discharge at } \\
\text { edge, moss, algae, little } \\
\text { floc on the rocks }\end{array}$ \\
\hline 383230 & Cheat River PA2 & $\begin{array}{c}\text { Morganto } \\
\text { wn North } \\
\text { C } \\
\end{array}$ & I-Drift & Undisturbed & Pittsburgh & $\begin{array}{l}39,44.6^{\prime} \\
79,53.2^{\prime}\end{array}$ & $\begin{array}{l}\text { Six open, six covered, } \\
\text { heavily subsided }\end{array}$ & $\begin{array}{l}\text { Seeps at edge of spoil, } \\
\text { swampy area, lots of } \\
\text { leaves/garbage, little floc }\end{array}$ \\
\hline 383630 & Cheat River 3 & \begin{tabular}{|c|} 
Frederick \\
No. 1 \\
Mine
\end{tabular} & I-Drift & Disturbed & Pittsburgh & $\begin{array}{l}39,41.7^{\prime} \\
79,45.0^{\prime}\end{array}$ & $\begin{array}{l}\text { Heavy subsidence, Mine } \\
\text { Seal \#1 }\end{array}$ & $\begin{array}{l}\text { Pipe flowing out and } \\
\text { spreading to large dead } \\
\text { area, lots of floc }\end{array}$ \\
\hline 590060 & Bull Run 5 & Terri Lynn & $\begin{array}{l}\text { I-Strip + } \\
\text { Drift }\end{array}$ & Undisturbed & Upper Freeport & $\begin{array}{l}39,33.6^{\prime} \\
79,45.0^{\prime}\end{array}$ & $\begin{array}{l}\text { No reclamation, old } \\
\text { workings stripped out and } \\
\text { drained }\end{array}$ & $\begin{array}{l}\text { Large area with seeps } \\
\text { flowing to the stream, } \\
\text { entire area has iron } \\
\text { precipitation and dead } \\
\text { vegetation. }\end{array}$ \\
\hline 590150 & Muddy Creek 11 & $\begin{array}{l}\text { RuthBell } \\
\# 3\end{array}$ & I-Drift & Disturbed & Upper Freeport & $\begin{array}{l}39,32.6^{\prime} \\
79,37.7\end{array}$ & $\begin{array}{l}\text { Ruth Bell Coal Co, at end } \\
\text { of syncline, may be tough } \\
\text { to seal }\end{array}$ & $\begin{array}{l}\text { AML project, sealed } \\
\text { portals into } 2 \text { pipes that } \\
\text { flow together down } \\
\text { limestone/cement ditch, } \\
\text { deep red stain on rocks }\end{array}$ \\
\hline
\end{tabular}




\begin{tabular}{|c|c|c|c|c|c|c|c|c|}
\hline \multicolumn{2}{|c|}{ Discharge \# } & \multirow{2}{*}{$\begin{array}{l}\text { Mine } \\
\text { Name }\end{array}$} & \multirow{2}{*}{$\begin{array}{l}\text { Mining } \\
\text { Method }\end{array}$} & \multirow[t]{2}{*}{ Category } & \multirow[t]{2}{*}{ Coal Seam } & \multirow{2}{*}{$\begin{array}{c}\text { Lat/Long } \\
\text { (degree,mi } \\
\text { nute) }\end{array}$} & \multirow{2}{*}{$\begin{array}{l}\text { Comments from the } \\
1960 \text { s Study }\end{array}$} & \multirow{2}{*}{$\begin{array}{l}\text { Comments from the } \\
2000 \text { Study }\end{array}$} \\
\hline Old & New & & & & & & & \\
\hline 590200 & Martin Creek 3 & $\overline{\mathrm{Me}}$ & $\begin{array}{c}\text { I-Strip + } \\
\text { Drift }\end{array}$ & Disturbed & Upper Freeport & $\begin{array}{l}39,33.2^{\prime} \\
79,38.2^{\prime}\end{array}$ & $\begin{array}{l}\text { Roughly Disturbed, flow } \\
\text { from spoil, large area } \\
\text { destroyed, runs like a } \\
\text { stream creating large } \\
\text { swampy area }\end{array}$ & $\begin{array}{l}\text { Area behind and across } \\
\text { surface mined, large } \\
\text { amount of deep red floc }\end{array}$ \\
\hline 590250 & Conner Run 1 & Rock Bull & $\begin{array}{c}\text { I-Strip + } \\
\text { Drift }\end{array}$ & Disturbed & Upper Freeport & $\begin{array}{l}39,33.8^{\prime} \\
79,40.7^{\prime}\end{array}$ & $80 \%$ Disturbed & \begin{tabular}{|l|} 
Spoil around area where \\
sample taken, three areas \\
where water coming out of \\
ground, took sample \\
where mix, small amount \\
of large flaked floc
\end{tabular} \\
\hline 590260 & Glade Run 5 & $\begin{array}{l}\text { Valley } \\
\text { Point A }\end{array}$ & $\begin{array}{c}\text { I-Strip + } \\
\text { Drift }\end{array}$ & Disturbed & Upper Freeport & $\begin{array}{l}39,34.0^{\prime} \\
79,39.7^{\prime}\end{array}$ & $\begin{array}{l}\text { Assume need } 50 \% \\
\text { reclamation to cover coal } \\
\text { and drift openings }\end{array}$ & $\begin{array}{l}\text { Large area down off of hill, } \\
\text { comes out of large spoil } \\
\text { area, leaves and floc } \\
\text { mixed }\end{array}$ \\
\hline 590270 & Glade Run 4 & $\begin{array}{l}\text { Valley } \\
\text { point B }\end{array}$ & $\begin{array}{c}\text { I-Strip + } \\
\text { Drift }\end{array}$ & Disturbed & Upper Freeport & $\begin{array}{l}39,34.2^{\prime} \\
79,37.9^{\prime}\end{array}$ & $\begin{array}{l}\text { Flow from spoil, area } \\
\text { okay }\end{array}$ & $\begin{array}{l}\text { Seep is causing a large } \\
\text { dead area with orange } \\
\text { coloration, small } \\
\text { impoundment near the } \\
\text { side of the road, surface } \\
\text { mined in the surrounding } \\
\text { area }\end{array}$ \\
\hline 590280 & Fickey Run 5 & $\begin{array}{c}\text { Kambric } \\
\# 36 \mathrm{~A}\end{array}$ & I-Drift & Disturbed & Upper Freeport & $\begin{array}{l}39,33.9^{\prime} \\
79,38.5^{\prime}\end{array}$ & $\begin{array}{l}\text { Scattered gob piles, } \\
\text { closed by roof fall }\end{array}$ & $\begin{array}{l}\text { SAPS constructed at this } \\
\text { site, flows out of portal, } \\
\text { precipitation on rocks, light } \\
\text { iron coating }\end{array}$ \\
\hline 590290 & Fickey Run 9 & Tri State & I-Drift & Disturbed & Upper Freeport & $\begin{array}{l}39,33.1^{\prime} \\
79,38.1^{\prime}\end{array}$ & $\begin{array}{l}\text { R\&O Coal Co., flows } \\
\text { form two openings and } \\
\text { gob pile }\end{array}$ & $\begin{array}{l}\text { Large area like small } \\
\text { stream, looks as though } \\
\text { flow can be much higher, } \\
\text { runs off side hill from } \\
\text { surface mined area } \\
\end{array}$ \\
\hline 590300 & Muddy Creek 9 & Tri State & A-Drift & Disturbed & Upper Freeport & $\begin{array}{l}39,33.4^{\prime} \\
79,38.0^{\prime}\end{array}$ & $\begin{array}{l}\text { Old Tri State Mine, pillars } \\
\text { being pulled by KCD } \\
\text { Coal Co. }\end{array}$ & $\begin{array}{l}\text { Water and precipitation is } \\
\text { dark purple, flows through } \\
\text { limestone channel, directly } \\
\text { to Muddy Creek }\end{array}$ \\
\hline
\end{tabular}




\begin{tabular}{|c|c|c|c|c|c|c|c|c|}
\hline \multicolumn{2}{|c|}{ Discharge \# } & \multirow{2}{*}{$\begin{array}{c}\text { Mine } \\
\text { Name }\end{array}$} & \multirow{2}{*}{$\begin{array}{l}\text { Mining } \\
\text { Method }\end{array}$} & \multirow[t]{2}{*}{ Category } & \multirow[t]{2}{*}{ Coal Seam } & \multirow{2}{*}{$\begin{array}{c}\text { Lat/Long } \\
\text { (degree,mi } \\
\text { nute) }\end{array}$} & \multirow{2}{*}{$\begin{array}{l}\text { Comments from the } \\
1960 \text { s Study }\end{array}$} & \multirow{2}{*}{$\begin{array}{l}\text { Comments from the } \\
2000 \text { Study }\end{array}$} \\
\hline Old & New & & & & & & & \\
\hline 590340 & Fickey Run 2 & Tri State & I-Drift & Disturbed & Upper Freeport & $\begin{array}{l}39,34.2^{\prime} \\
79,38.1^{\prime}\end{array}$ & Portals caved & $\begin{array}{l}\text { Area has been surface } \\
\text { mined, seep emanates } \\
\text { near bottom of tree-line, } \\
\text { looks like pond left in, may } \\
\text { contain lime }\end{array}$ \\
\hline 590350 & Fickey Run 4 & Tri State & I-Drift & Disturbed & Upper Freeport & $\begin{array}{l}39,34.2^{\prime} \\
79,38.1\end{array}$ & $\begin{array}{l}\text { Scattered gob, may drain } \\
\text { in wet weather, portals } \\
\text { caved }\end{array}$ & $\begin{array}{l}\text { Area was/is being treated } \\
\text { with lime, ditch runs along } \\
\text { bottom of disturbed area, } \\
\text { rock wall, cattails, little floc }\end{array}$ \\
\hline 590360 & Fickey Run 1 & $\begin{array}{l}\text { Valley } \\
\text { Point C }\end{array}$ & I-Drift & Undisturbed & Upper Freeport & $\begin{array}{l}39,34.8 \\
79,37.9\end{array}$ & $\begin{array}{l}\text { Liston Coal Co., portals } \\
\text { caved }\end{array}$ & $\begin{array}{l}\text { Collected sample after } \\
\text { mixing of } 3 \text { portals and } \\
\text { additional seeps, flows } \\
\text { into large impoundment, } \\
\text { large amount of orange } \\
\text { floc coating bottom of the } \\
\text { channel }\end{array}$ \\
\hline 590600 & Glade Run 1 & Liston & $\begin{array}{l}\text { I-Strip }+ \\
\text { Drift }\end{array}$ & Disturbed & Upper Freeport & $\begin{array}{l}39,35.3^{\prime} \\
79,38.1^{\prime}\end{array}$ & $\begin{array}{l}\text { Stripped into workings, } \\
\text { flow also ran from spoil }\end{array}$ & $\begin{array}{l}\text { Area surrounding has } \\
\text { been mined, sample taken } \\
\text { at seep out of ground, } \\
\text { green algae, no iron floc }\end{array}$ \\
\hline 590710 & Martin Creek 2 & $\mathrm{Me}$ & I-Drift & Undisturbed & Upper Freeport & $\begin{array}{l}39,33.3^{\prime} \\
79,39.2^{\prime}\end{array}$ & $\begin{array}{l}\text { Caved portals, water } \\
\text { flows through gob }\end{array}$ & $\begin{array}{l}\text { Discharge channeled } \\
\text { through valley, entire area } \\
\text { is swampy, see shiny oil } \\
\text { areas (bacteria), little floc }\end{array}$ \\
\hline 590720 & Martin Creek 1 & $\begin{array}{l}\text { Valley } \\
\text { Point D }\end{array}$ & I-Drift & Disturbed & Upper Freeport & $\begin{array}{l}39,33.7^{\prime} \\
79,38.5^{\prime}\end{array}$ & Should be backfilled & $\begin{array}{l}\text { Water deep purple, low } \\
\text { pH, flows as stream from } \\
\text { bottom of gob pile, area } \\
\text { above and surrounding } \\
\text { has been surface mined }\end{array}$ \\
\hline 590730 & Fickey Run 7 & \#36B & I-Drift & Disturbed & Upper Freeport & $\begin{array}{l}39,33.6^{\prime} \\
79,38.5^{\prime}\end{array}$ & Near auger holes all wet & $\begin{array}{l}\text { Tipple area, water running } \\
\text { off hill from collapsed } \\
\text { portal, long boney piles in } \\
\text { area, runs under road into } \\
\text { stream, no floc, orange } \\
\text { color in mud }\end{array}$ \\
\hline
\end{tabular}




\begin{tabular}{|c|c|c|c|c|c|c|c|c|}
\hline \multicolumn{2}{|c|}{ Discharge \# } & \multirow{2}{*}{$\begin{array}{l}\text { Mine } \\
\text { Name }\end{array}$} & \multirow{2}{*}{$\begin{array}{l}\text { Mining } \\
\text { Method }\end{array}$} & \multirow[t]{2}{*}{ Category } & \multirow[t]{2}{*}{ Coal Seam } & \multirow{2}{*}{$\begin{array}{c}\text { Lat/Long } \\
\text { (degree,mi } \\
\text { nute) }\end{array}$} & \multirow{2}{*}{$\begin{array}{l}\text { Comments from the } \\
1960 \text { s Study }\end{array}$} & \multirow{2}{*}{$\begin{array}{l}\text { Comments from the } \\
2000 \text { Study }\end{array}$} \\
\hline Old & New & & & & & & & \\
\hline 590740 & Fickey Run 8 & Grooves & I-Drift & Disturbed & Upper Freeport & $\begin{array}{l}39,33.3^{\prime} \\
79,38.6^{\prime}\end{array}$ & $\begin{array}{l}\text { One air shaft, one closed } \\
\text { portal }\end{array}$ & $\begin{array}{l}\text { Flows up out of ground at } \\
\text { edge of surface mined } \\
\text { area, water flow through } \\
\text { pipe down over hill to a } \\
\text { stream }\end{array}$ \\
\hline 590750 & Fickey Run 6 & \#36B & I-Drift & Disturbed & Upper Freeport & $\begin{array}{l}39,33.8 \\
79,38.5\end{array}$ & $\begin{array}{l}\text { Two covered portals, } \\
\text { flows over gob }\end{array}$ & $\begin{array}{l}\text { Free flowing down ditch } \\
\text { area, area above all strip } \\
\text { mined }\end{array}$ \\
\hline 590770 & Muddy Creek 10 & Tri State & I-Drift & Disturbed & Upper Freeport & $\begin{array}{l}39,33.1^{\prime} \\
79,38.0^{\prime}\end{array}$ & $\begin{array}{l}\text { Spring, possible } \\
\text { openings }\end{array}$ & $\begin{array}{l}\text { Seep that flows into } \\
\text { Muddy Creek, opposite } \\
\text { side of road is AML } \\
\text { project, hardly flowing, } \\
\text { ponded water, floc }\end{array}$ \\
\hline 590820 & Fickey Run & Martin & A-Drift & Disturbed & Upper Freeport & $\begin{array}{l}39,34.6^{\prime} \\
79,38.1^{\prime}\end{array}$ & Zip Coal Co, gravity flow & $\begin{array}{l}\text { Seep from bottom of } \\
\text { disturbed area, flows } \\
\text { through ditch, dry } \\
\text { sometimes during the year }\end{array}$ \\
\hline 590880 & Glade Run 3 & $\begin{array}{l}\text { Valley } \\
\text { Point E }\end{array}$ & I-Drift & Undisturbed & Upper Freeport & $\begin{array}{l}39,35.0^{\prime} \\
79,38.2^{\prime}\end{array}$ & $\begin{array}{l}\text { Liston Bros Coal, caved } \\
\text { openings }\end{array}$ & $\begin{array}{l}\text { Free flow into } \\
\text { impoundment, water clear } \\
\text { with course floc settled out }\end{array}$ \\
\hline 590890 & Glade Run 2 & $\begin{array}{l}\text { Valley } \\
\text { Point F }\end{array}$ & I-Drift & Undisturbed & Upper Freeport & $\begin{array}{l}39,35.1^{\prime} \\
79,38.2^{\prime}\end{array}$ & $\begin{array}{l}\text { Possible dog holes from } \\
\text { mines, two open, one } \\
\text { draining }\end{array}$ & $\begin{array}{l}\text { Free flowing from opening, } \\
\text { fine iron floc, mixes with } \\
\text { small tributary }\end{array}$ \\
\hline
\end{tabular}




\section{Stream Information and Study Area}

The study area is located in Cheat River Basin in northern West Virginia (Appendix A). The study sites drain to various streams in the USGS quadrangles of Cuzzart, Kingwood, Valley Point, Masontown, and Morgantown North (Appendix A).

The Cheat River Basin lies in the Allegheny Mountains of the Appalachian Plateau, having large parallel ridges separated by mature valleys. The streams in the area are characterized by steep gradients, rocky channels, and high velocities. The geography of the area is dominated by rocks of the Paleozoic Age, with systems in the Pennsylvanian, Mississippian, and Devonian Age. The rocks are massive sandstones, silt and clay shale, limestones, fire clays and coal. Coal beds are dominantly from the Pennsylvanian Age, and are associated with thin and erratic limestone layers, creating little potential for neutralization. The total area of the basin is 3675 $\mathrm{km}^{2}$, with the total length of the Cheat River being $250 \mathrm{~km}$. The climate of the area is moderate, with normal variations associated with the latitude and elevation. The average annual temperature is $10^{\circ} \mathrm{C}\left(50^{\circ} \mathrm{F}\right)$ with a summer average of approximately $18^{\circ} \mathrm{C}\left(65^{\circ} \mathrm{F}\right)$ and a winter temperature of $4.5^{\circ} \mathrm{C}\left(40^{\circ} \mathrm{F}\right)$. The normal precipitation within the basin is $115 \mathrm{~cm}$, and an average snowfall of $270 \mathrm{~cm}$ near the head, and $80 \mathrm{~cm}$ near Morgantown at the mouth (DNR 1982).

The first settlement in the Basin occurred near Bruceton Mills, Preston County in 1769. Up until the 1850s the area was still mostly inaccessible and undeveloped. Coal played a major role in the development of the economic and social environment of the Cheat River Basin. Logging was also an important economic force in the area, which created a greater need for coal as an energy source. During WWI, the demand for coal increased dramatically, but decreased again during the depression. Another surge was seen during WWII with the opening of numerous drift mines and the expansion of surface mining. In recent years, the area has become more recreational, being dominated by hunting, fishing and vacationing (DNR 1982). 
Approximately $527 \mathrm{~km}$ of streams were affected by coal mine drainage within the Basin in 1971 when an extensive study was conducted to determine where remediation should be focused. The Cheat River consists of five watersheds: Lower Cheat, Big Sandy, Upper Cheat, Shavers Fork, and Blackwater River. This study focused on tributaries of the Upper and Lower Cheat watersheds, where the majority of the pollution is entering the Cheat. The Lower Cheat River drains $440 \mathrm{~km}^{2}$ and is located between Albright,West Virginia and Point Marion, PA. In this area there are 14 mineable coals, and many small drift mines exist. During the study in 1971, 191 openings were found from both active and abandoned surface and underground mines. It was determined that $80 \%$ of the total net acid load was from inactive mines, contributing $86 \%$ of the total acid loads discharging to the Cheat River. Over $232 \mathrm{~km}$ of stream were affected in this area, mostly from Muddy Creek, which contributes $25 \%$ of the acid load. The Upper Cheat River drains $854 \mathrm{~km}^{2}$ and is found from Parsons to Albright, WV. Most of the mining in this area occurred on Upper Freeport coal since the late 1800s. In this area, 213 sites were found, with $25 \%$ of the pollution emanating from inactive deep mines. Over $48 \mathrm{~km}$ of streams are degraded between Tunnelton and Kingwood (EPA 1971).

The major tributaries contributing most of the pollution to the Cheat River are Muddy Creek, Bull Run, Greens Run, Morgan Run, Pringle Run, Heather Run, and Lick Run. Muddy Creek drains $88 \mathrm{~km}^{2}$ and flows $25 \mathrm{~km}$ in a westerly direction through Preston County to the Cheat River at Albright. Nine coal beds exist in the Muddy Creek area, with the Upper Freeport and Bakerstown being the most extensively mined. Martin Creek is the big contributor to the degradation of Muddy Creek. Martin has a pH of 6.8 at the headwaters and decreases to 3.2 at the mouth. Martin dumps $75 \%$ of the total acidity and iron, along with $80 \%$ of the total manganese into Muddy Creek. Other tributaries, such as Fickey and Glade, also adversely affect Muddy Creek. Bull Run drains $45 \mathrm{~km}^{2}$ and the area has been extensively mined, and inadequately reclaimed. The main pollution loadings come from Lick Run tributary which is 
lined with abandoned mine sites. These streams are sparsely populated, and extensively mined for the Upper Freeport coal. Most of the drainage seeps from old abandoned spoil. Morgan Run drains $15 \mathrm{~km}^{2}$ and has been mined for both the Bakerstown and Upper Freeport coals. This stream is dominated by low levels of dissolved oxygen, mainly due to human waste found in the stream. Pringle, Heather, and Lick Run are each heavily affected with AMD $100 \%$ of the time, and also contain high levels of iron, manganese, and sulfate. The streams receive drainage from both large abandoned spoils and deep mine portals (EPA 1971).

\section{Coal Beds}

The Pittsburgh coal bed is the lowest member of the Monongahela Series. The bed has a low overall sulfur content (1.37\%) and also a low ash content $(5.48 \%)$. It is characterized by its regularity of structure and the uniform purity of composition. The Pittsburgh coal is composed of alternate layers of coal and slate or shale. A typical Pittsburgh coal cross-section shows a 3-m layer of good coal, a 0.7-m layer of bone coal or slatey coal, and another 2-3-m layer of good coal. The Pittsburgh coal located at the Monongahela River, near Morgantown, is located close to the surface (Hennen and Reger 1914).

The Bakerstown coal bed is the lowest mineable coal in the Conemaugh measure of Preston County. It averages only $0.6-\mathrm{m}$ thick. This bed has a low sulfur content (1.84\%) and also a low ash content (4.80\%). A typical cross-section is a layer of shale, boney coal, good coal, and finally another layer of shale. The Bakerstown coal lays 22 to $30 \mathrm{~m}$ below the Ames limestones, and therefore rarely releases AMD during and after surface mining (Hennen and Reger 1914).

The Upper Freeport coal bed is the topmost strata of the Allegheny Formation of the Pennsylvanian System. Freeport coal is uniformly low in sulfur $(<1.5 \%)$ and has a comparatively low ash content ( 8 to $12 \%$ ). It is multiple-bedded and is divided into a top coal and bottom coal, separated by a shale interlayer, all of which average a total of $1.8 \mathrm{~m}$ thick (Hennen and Reger

1914). The Allegheny Formation is capped by the Upper Freeport coal, and the overlying strata 
in the Conemaugh Group contains several massive sandstones and some shales. Limestone or alkaline-bearing rock units are not generally found within $50 \mathrm{~m}$ above the Upper Freeport coal in this area, so very little overlying geologic material is available for acid neutralization.

The Lower Freeport coal bed occurs 14 to $18 \mathrm{~m}$ below the top of the Allegheny series. The coal is fairly high in sulfur content (3.5\%), but remains relatively low in ash content (15\%). It is a multiple bedded bed and ranges from 0.3 to $1.5 \mathrm{~m}$ thick. It is generally too thin and worthless for mining in most of Preston County. It was originally mined and used as a domestic fuel by local farmers. An advantage to mining Lower Freeport coal is that it normally has Lower Freeport limestone associated with it, adding alkalinity and neutralization (Hennen and Reger 1914).

The Upper Kittanning coal bed is found 24 to $30 \mathrm{~m}$ below the Upper Freeport. It has a relatively high sulfur content $(2.37 \%)$, but the ash content remains relatively low $(10.07 \%)$. It is very irregular in its distribution, and often is completely absent. When found, the bed seldom exceeds $1.2 \mathrm{~m}$. The Upper Kittanning bed is double bedded and sometimes multiple bedded. The bed carries a thin layer of parting slate approximately 20 to $30 \mathrm{~cm}$ above the base.

\section{Historical and Additional Data}

The history of each mine site was researched to gather additional information. Most information was found in the Annual Report of the West Virginia Department of Mines that have been submitted since the 1800 s on active operations. The Report contains the mine name, operator name, tons of coal removed, the number of employees, injuries, etc. We were able to track some of the mines for their entire working period, and others, due to name changes, were impossible to find. Other information was found at the West Virginia Geologic and Economic Survey in Morgantown, WV. Mine maps were found with outlines of the underground mine workings, coal outcrops and coal bed depths. The maps were used to determine which mine was 
being sampled in 1968. We also obtained additional information from the Mine Map Repository in Pittsburgh, Pennsylvania.

The mine sites we investigated are listed above in table format, along with their associated discharge points. The discharges are labeled according to the particular stream into which they discharge. Some of the mines discharge water at more than one location. The discharges from the same mine pool may differ in chemistry due to varying flow paths within the mines, but the overall trends are related. 


\section{Appendix C}

Water Quality Results for Underground Mines for 1968, 1980, 1999-2000 


\begin{tabular}{|c|c|c|c|c|c|c|c|c|c|c|c|c|}
\hline Year & $\begin{array}{l}\mathrm{pH} \\
\text { (SU) }\end{array}$ & $\begin{array}{l}\text { Flow } \\
(\text { L/min) }\end{array}$ & $\begin{array}{l}\text { Acidity } \\
(\mathrm{mg} / \mathrm{L})\end{array}$ & $\begin{array}{l}\text { Acidity } \\
\text { (kg/day) }\end{array}$ & $\begin{array}{l}\text { Alkalinity } \\
\text { (mg/L) }\end{array}$ & $\begin{array}{l}\text { Iron } \\
(\mathrm{mg} / \mathrm{L}) \\
\end{array}$ & $\begin{array}{l}\text { Iron } \\
\text { (kg/day) }\end{array}$ & $\begin{array}{l}\text { Aluminum } \\
(\mathrm{mg} / \mathrm{L})\end{array}$ & $\begin{array}{l}\text { Manganese } \\
(\mathrm{mg} / \mathrm{L})\end{array}$ & $\begin{array}{l}\text { Calcium } \\
(\mathrm{mg} / \mathrm{L})\end{array}$ & $\begin{array}{l}\text { Sulfate } \\
\text { (mg/L) }\end{array}$ & $\begin{array}{l}\text { Conductivity } \\
\text { (umhos/cm) }\end{array}$ \\
\hline \multicolumn{13}{|c|}{ Bull Run 1, Upper Freeport, Masontown, Disturbed } \\
\hline 1968 & 2.4 & 37 & 2805 & 145 & 0 & 800 & 41 & 260 & & & 3458 & 3750 \\
\hline 2000 & 2.9 & 19 & 1401 & 37 & 0 & 205 & 5 & 94 & 3 & 120 & 2055 & 1480 \\
\hline \multicolumn{13}{|c|}{ Bull Run 2, Upper Freeport, Masontown, Disturbed } \\
\hline 1968 & 2.4 & 4 & 1905 & 44 & 0 & 394 & 9 & 87 & & & 2561 & 3063 \\
\hline 2000 & 2.9 & 16 & 756 & 4 & 0 & 126 & 1 & 45 & 1 & 109 & 1644 & 1730 \\
\hline 1968 & 3.2 & 19 & 640 & 15 & 0 & 57 & 1 & 37 & & & 663 & 1826 \\
\hline 2000 & 7.5 & 17 & 0 & 0 & 1772 & 2 & 0 & 1 & 1 & 187 & 687 & 1140 \\
\hline \multicolumn{13}{|c|}{ Bull Run 4, Upper Freeport, Masontown, Undisturbed } \\
\hline 1968 & 3.3 & 11 & 250 & 4 & 0 & 82 & 1 & 1 & & & 556 & 1066 \\
\hline 2000 & 3 & 28 & 530 & 21 & 0 & 48 & 2 & 44 & 8 & 453 & 1199 & 2600 \\
\hline \multicolumn{13}{|c|}{ Bull Run 5, Upper Freeport, Valley Point, Undisturbed } \\
\hline 1968 & 2.9 & 56 & 1370 & 108 & 0 & 624 & 50 & 67 & & & 3276 & 3520 \\
\hline \multicolumn{13}{|c|}{ Cheat River 1, Pittsburgh, Morgantown North, Undisturbed } \\
\hline 1968 & 2.9 & 1 & 8818 & 18 & 0 & 366 & 1 & 90 & & & 7150 & 8106 \\
\hline 2000 & 2.1 & 56 & 1428 & 113 & 0 & 201 & 16 & 49 & 5 & 130 & 1519 & 2700 \\
\hline \multicolumn{13}{|c|}{ Cheat River 2, Pittsburgh, Morgantown North, Disturbed } \\
\hline 1968 & 3.3 & 12 & 1061 & 17 & 0 & 258 & 4 & 320 & & & 9750 & 9282 \\
\hline 2000 & 2.2 & 15 & 1033 & 22 & 0 & 203 & 4 & 54 & 10 & 103 & 1817 & 3000 \\
\hline \multicolumn{13}{|c|}{ Cheat River 3, Pittsburgh, Morgantown North, Disturbed } \\
\hline 1968 & 2.6 & 7 & 3300 & 35 & 0 & 600 & 6 & 142 & & & 3848 & 4324 \\
\hline 2000 & 3.1 & 30 & 1369 & 59 & 0 & 200 & 8 & 77 & 5 & 77 & 1773 & 2200 \\
\hline \multicolumn{13}{|c|}{ Cheat River 4, Pittsburgh, Morgantown North, Undisturbed } \\
\hline 1968 & 3.1 & 19 & 3603 & 95 & 0 & 824 & 22 & 65 & & & 4238 & 4614 \\
\hline 2000 & 2.7 & 4 & 431 & 2 & 0 & 19 & 0 & 41 & 5 & 149 & 917 & 1260 \\
\hline \multicolumn{13}{|c|}{ Cheat River 5, Pittsburgh, Morgantown North, Disturbed } \\
\hline 1968 & 2.6 & 19 & 1825 & 48 & 0 & 458 & 12 & 101 & & & 2392 & 3097 \\
\hline 1980 & 2.6 & & & & & 25 & & & 10 & & 1100 & 2100 \\
\hline
\end{tabular}




\begin{tabular}{|c|c|c|c|c|c|c|c|c|c|c|c|c|}
\hline Year & $\begin{array}{l}\mathrm{pH} \\
\text { (SU) }\end{array}$ & $\begin{array}{l}\text { Flow } \\
\text { (L/min) }\end{array}$ & $\begin{array}{l}\begin{array}{l}\text { Acidity } \\
\text { (mg/L) }\end{array} \\
\end{array}$ & $\begin{array}{l}\text { Acidity } \\
\text { (kg/day) }\end{array}$ & $\begin{array}{l}\text { Alkalinity } \\
\text { (mg/L) }\end{array}$ & $\begin{array}{l}\text { Iron } \\
(\mathrm{mg} / \mathrm{L})\end{array}$ & $\begin{array}{l}\text { Iron } \\
\text { (kg/day) } \\
\end{array}$ & $\begin{array}{l}\text { Aluminum } \\
(\mathrm{mg} / \mathrm{L})\end{array}$ & $\begin{array}{l}\text { Manganese } \\
(\mathrm{mg} / \mathrm{L})\end{array}$ & $\begin{array}{l}\begin{array}{l}\text { Calcium } \\
\text { (mg/L) }\end{array} \\
\end{array}$ & $\begin{array}{l}\begin{array}{l}\text { Sulfate } \\
\text { (mg/L) }\end{array} \\
\end{array}$ & $\begin{array}{l}\text { Conductivity } \\
\text { (umhos } / \mathrm{cm} \text { ) }\end{array}$ \\
\hline \multicolumn{13}{|c|}{ Cheat River 6, Upper Freeport, Masontown, Disturbed } \\
\hline 1968 & 2.6 & 78 & 1450 & 154 & 0 & 28 & 31 & 104 & & & 1612 & 2442 \\
\hline 2000 & 2.8 & 38 & 487 & 26 & 0 & 48 & 3 & 46 & 2 & 56 & 775 & 3000 \\
\hline \multicolumn{13}{|c|}{ Cheat River 7, Upper Freeport, Kingwood, Disturbed } \\
\hline 2000 & 3.3 & 19 & 101 & 3 & 0 & 17 & 1 & 14 & 1 & 34 & 176 & 720 \\
\hline \multicolumn{13}{|c|}{ Cheat River 8, Upper Freeport, Kingwood, Undisturbed } \\
\hline 1968 & & 4 & & & & & & & & & & \\
\hline 2000 & 5 & 6 & 0 & 0 & 42 & 1 & 0 & 1 & 1 & 16 & 22 & 130 \\
\hline \multicolumn{13}{|c|}{ Cheat River PA1, Pittsburgh, Morgantown North, Disturbed } \\
\hline 1968 & 3.3 & 298 & 2457 & 1027 & 0 & 449 & 188 & 141 & & & 2602 & 3078 \\
\hline 2000 & 3.7 & 22 & 563 & 18 & 0 & 78 & 2 & 34 & 5 & 79 & 833 & 2100 \\
\hline \multicolumn{13}{|c|}{ Cheat River PA2, Pittsburgh, Morgantown North, Undisturbed } \\
\hline 1968 & 2.7 & 12 & 4310 & 77 & 0 & 852 & 15 & 282 & & & 4550 & 4880 \\
\hline 2000 & 3.1 & 4 & 1314 & 7 & 0 & 96 & 1 & 84 & 6 & 42 & 1237 & 2700 \\
\hline \multicolumn{13}{|c|}{ Conner Run 1, Upper Freeport, Valley Point, Disturbed } \\
\hline 1999 & 3.1 & 19 & 88 & 0 & 0 & 4 & 1 & 7 & 8 & 85 & & 1870 \\
\hline 2000 & 3.3 & 19 & 215 & 6 & 0 & 2 & 1 & 28 & 18 & 219 & & \\
\hline \multicolumn{13}{|c|}{ Fickey Run 1, Upper Freeport, Valley Point, Undisturbed } \\
\hline 1968 & 3 & 6 & 3270 & 26 & 0 & 672 & 5 & 180 & & & 3744 & 4047 \\
\hline 1999 & 3.3 & 113 & 154 & 25 & 0 & 7 & 1 & 5 & 3 & 172 & 1883 & 1460 \\
\hline \multicolumn{13}{|c|}{ Fickey Run 2, Upper Freeport, Valley Point, Disturbed } \\
\hline 1968 & & 0 & & & & & & & & & & \\
\hline 1999 & 6.2 & 37.8 & 162 & 9 & 84 & 75 & 4 & 1 & 15 & 312 & & 260 \\
\hline \multicolumn{13}{|c|}{ Fickey Run 3, Upper Freeport, Valley Point, Disturbed } \\
\hline 1968 & 2.9 & 31 & 420 & 12 & 0 & 82 & 2 & 7 & & & 1456 & 2539 \\
\hline 1999 & 2.8 & 189 & 3694 & 977 & 0 & 194 & 51 & 168 & 22 & 252 & & 560 \\
\hline \multicolumn{13}{|c|}{ Fickey Run 4, Upper Freeport, Valley Point, Disturbed } \\
\hline 1968 & & 0 & & & & & & & & & & \\
\hline 1999 & 6.8 & 4 & 0 & 0 & 217 & 3 & 1 & 1 & 9 & & & 310 \\
\hline \multicolumn{13}{|c|}{ Fickey Run 5, Upper Freeport, Valley Point, Disturbed } \\
\hline 1968 & 3.1 & 9 & 515 & 7 & 0 & 88 & 1 & 24 & & & 585 & 1463 \\
\hline 1980 & 2.5 & 1 & 460 & 1 & 0 & 42 & 1 & & 0 & & 500 & 493 \\
\hline
\end{tabular}




\begin{tabular}{|c|c|c|c|c|c|c|c|c|c|c|c|c|}
\hline Year & $\begin{array}{l}\mathrm{pH} \\
\text { (SU) }\end{array}$ & $\begin{array}{l}\text { Flow } \\
\text { (L/min) }\end{array}$ & $\begin{array}{l}\begin{array}{l}\text { Acidity } \\
\text { (mg/L) }\end{array} \\
\end{array}$ & $\begin{array}{l}\text { Acidity } \\
\text { (kg/day) }\end{array}$ & $\begin{array}{l}\text { Alkalinity } \\
\text { (mg/L) }\end{array}$ & $\begin{array}{l}\text { Iron } \\
(\mathrm{mg} / \mathrm{L})\end{array}$ & $\begin{array}{l}\text { Iron } \\
\text { (kg/day) } \\
\end{array}$ & $\begin{array}{l}\text { Aluminum } \\
(\mathrm{mg} / \mathrm{L})\end{array}$ & $\begin{array}{l}\text { Manganese } \\
(\mathrm{mg} / \mathrm{L})\end{array}$ & $\begin{array}{l}\text { Calcium } \\
\text { (mg/L) }\end{array}$ & $\begin{array}{l}\begin{array}{l}\text { Sulfate } \\
\text { (mg/L) }\end{array} \\
\end{array}$ & $\begin{array}{l}\text { Conductivity } \\
\text { (umhos } / \mathrm{cm} \text { ) }\end{array}$ \\
\hline \multicolumn{13}{|c|}{ Fickey Run 6, Upper Freeport, Valley Point, Disturbed } \\
\hline 1968 & 2.4 & 1 & 1300 & 0 & 0 & 288 & 1 & 112 & & & 1456 & \\
\hline 1999 & 3.6 & 11 & 118 & 2 & 1 & 13 & 1 & 1 & 2 & 307 & 1249 & \\
\hline \multicolumn{13}{|c|}{ Fickey Run 7, Upper Freeport, Valley Point, Disturbed } \\
\hline 1968 & 2.8 & 3 & 1670 & 7 & 0 & 237 & 78 & 157 & & & 2007 & 2997 \\
\hline 1999 & 2.2 & 56 & 1086 & 86 & 0 & 19 & 1 & 78 & 12 & 194 & 1118 & 2200 \\
\hline \multicolumn{13}{|c|}{ Fickey Run 8, Upper Freeport, Valley Point, Disturbed } \\
\hline 1968 & 3 & 49 & 1505 & 103 & 0 & 288 & 20 & 84 & & & 1872 & 2671 \\
\hline 1980 & 2.3 & 1 & 625 & 1 & 0 & 120 & 1 & & 1.2 & & 100 & 1700 \\
\hline \multicolumn{13}{|c|}{ Fickey Run 9, Upper Freeport, Valley Point, Disturbed } \\
\hline $\begin{array}{r}1968 \\
\text { Spr }\end{array}$ & 2.8 & 17 & 1920 & 45 & 0 & 378 & 9 & 88 & & & 1501 & 3400 \\
\hline 1999 & 2.6 & 19 & 498 & 13 & 0 & 16 & 1 & 42 & 42 & 283 & 1311 & 3300 \\
\hline \multicolumn{13}{|c|}{ Glade Run 1, Upper Freeport, Valley Point, Disturbed } \\
\hline 1968 & 3.1 & 15 & 1705 & 36 & 0 & 228 & 5 & 146 & & & 2626 & 3000 \\
\hline 1999 & 3.2 & 4 & 151 & 1 & 0 & 7 & 1 & 14 & 1 & 31 & 170 & 850 \\
\hline \multicolumn{13}{|c|}{ Glade Run 2, Upper Freeport, Valley Point, Undisturbed } \\
\hline 1968 & 3.6 & 4 & 390 & 2 & 0 & 53 & 1 & 29 & & & 702 & 1374 \\
\hline 1999 & 4.3 & 19 & 179 & 5 & 2.5 & 17 & 1 & 40 & 2 & 64 & 520 & 440 \\
\hline \multicolumn{13}{|c|}{ Glade Run 3, Upper Freeport, Valley Point, Undisturbed } \\
\hline 1968 & 2.8 & 11 & 675 & 11 & 0 & & & & & & 1118 & 2208 \\
\hline 1999 & 3.8 & 11 & 412 & 7 & 0 & 37 & 1 & 53 & 2 & 72 & 368 & 1110 \\
\hline \multicolumn{13}{|c|}{ Glade Run 4, Upper Freeport, Valley Point, Disturbed } \\
\hline 1968 & 2.9 & 19 & & & & & & & & & & \\
\hline 1980 & 2.7 & 0 & 285 & 0 & 0 & 6 & 0 & & 1 & & 560 & 484 \\
\hline \multicolumn{13}{|c|}{ Glade Run 5, Upper Freeport, Valley Point, Disturbed } \\
\hline 1968 & & & 1765 & & 0 & 158 & & 150 & & & 2184 & 2991 \\
\hline 1999 & 3.6 & 8 & 283 & 3 & 0 & 4 & 1 & 33 & 25 & 300 & & 1990 \\
\hline \multicolumn{13}{|c|}{ Green Run 1, Upper Freeport, Kingwood, Undisturbed } \\
\hline 1968 & & 6 & & & & & & & & & & \\
\hline 2000 & 2.2 & 25 & 702 & 6 & 0 & 117 & 1 & 42 & 3 & 61 & & 1900 \\
\hline \multicolumn{13}{|c|}{ Green Run 2, Upper Freeport, Kingwood, Undisturbed } \\
\hline 1968 & 4 & & 8 & & 6 & 1 & 0 & 1 & & & 14 & 80 \\
\hline 2000 & 4.5 & 1 & 4 & 0 & 13 & 6 & 0 & 2 & 1 & 13 & 47 & 20 \\
\hline
\end{tabular}




\begin{tabular}{|c|c|c|c|c|c|c|c|c|c|c|c|c|}
\hline Year & $\begin{array}{l}\mathrm{pH} \\
\text { (SU) }\end{array}$ & $\begin{array}{l}\text { Flow } \\
\text { (L/min) }\end{array}$ & $\begin{array}{l}\text { Acidity } \\
\text { (mg/L) }\end{array}$ & $\begin{array}{l}\text { Acidity } \\
\text { (kg/day) }\end{array}$ & $\begin{array}{l}\text { Alkalinity } \\
\text { (mg/L) }\end{array}$ & $\begin{array}{l}\text { Iron } \\
\text { (mg/L) }\end{array}$ & $\begin{array}{l}\text { Iron } \\
\text { (kg/day) }\end{array}$ & $\begin{array}{l}\text { Aluminum } \\
\text { (mg/L) }\end{array}$ & $\begin{array}{l}\text { Manganese } \\
\text { (mg/L) }\end{array}$ & $\begin{array}{l}\text { Calcium } \\
\text { (mg/L) }\end{array}$ & $\begin{array}{l}\text { Sulfate } \\
\text { (mg/L) }\end{array}$ & $\begin{array}{l}\text { Conductivity } \\
\text { (umhos/cm) }\end{array}$ \\
\hline \multicolumn{13}{|c|}{ Green Run 3, Upper Freeport, Kingwood, Disturbed } \\
\hline 1968 & 2.5 & & 1504 & & 0 & 288 & & 108 & & & 1508 & 2104 \\
\hline 2000 & 2.1 & 30 & 1932 & 82 & 0 & 203 & 9 & 121 & 14 & 30 & 1521 & 3000 \\
\hline \multicolumn{13}{|c|}{ Lake Lynn 1, Pittsburgh, Morgantown North, Undisturbed } \\
\hline 1968 & 2.8 & 38 & 1368 & 72 & 0 & 495 & 26 & 100 & & & 8861 & 1320 \\
\hline 1980 & 2 & 1 & 605 & 1 & 0 & 90 & 1 & & 2 & & 1000 & 2060 \\
\hline \multicolumn{13}{|c|}{ Lake Lynn 2, Pittsburgh, Morgantown North, Disturbed } \\
\hline 1968 & 3.2 & 38 & 4690 & 248 & 0 & 131 & 7 & 302 & & & 1105 & 5550 \\
\hline 1980 & 2 & 1 & 3800 & 1 & 0 & 1000 & 1 & & 0 & & 960 & 5660 \\
\hline \multicolumn{13}{|c|}{ Lake Lynn 3, Pittsburgh, Morgantown North, Disturbed } \\
\hline 1968 & 3.1 & 480 & 4988 & 3352 & 0 & 477 & 321 & 532 & & & 2593 & 5847 \\
\hline 1980 & 2 & 1 & 1930 & 1 & 0 & 350 & 1 & & 8 & 2600 & 3690 & \\
\hline \multicolumn{13}{|c|}{ Lick Run 1, Upper Freeport, Kingwood, Disturbed } \\
\hline 2000 & 2.2 & 19 & 1409 & 38 & 0 & 200 & 5 & 106 & 2 & 131 & 226 & 3100 \\
\hline \multicolumn{13}{|c|}{ Martin Creek 1, Upper Freeport, Valley Point, Undisturbed } \\
\hline 1999 & 2.6 & 30 & 1479 & 63 & 0 & 131 & 6 & 81 & 3 & 96 & 770 & 2500 \\
\hline \multicolumn{13}{|c|}{ Martin Creek 2, Upper Freeport, Valley Point, Undisturbed } \\
\hline 1968 & 2.7 & 57 & 2315 & 184 & 0 & 640 & 51 & 161 & & & 990 & 3047 \\
\hline 1980 & 2.4 & 1 & 545 & 1 & 0 & 80 & 1 & & 0 & & 1100 & 1832 \\
\hline \multicolumn{13}{|c|}{ Martin Creek 3, Upper Freeport, Valley Point, Disturbed } \\
\hline 1968 & 3 & 6 & 490 & 4 & 0 & 105 & 1 & 17 & & & 520 & 1250 \\
\hline 1999 & 5.5 & 57 & 253 & 20 & 80 & 70 & 6 & 1 & 19 & 346 & 1543 & 210 \\
\hline \multicolumn{13}{|c|}{ Middle River 1, Upper Freeport, Masontown, Disturbed } \\
\hline 1968 & 2.7 & 334 & 917 & 430 & 0 & 165 & 78 & 46 & & & 2405 & 2131 \\
\hline 2000 & 3.2 & 38 & 291 & 15 & 0 & 23 & 1 & 30 & 1 & 56 & 578 & 2600 \\
\hline \multicolumn{13}{|c|}{ Morgan Run 1, Upper Freeport, Kingwood, Disturbed } \\
\hline 2000 & 3.5 & 38 & 104 & 6 & 0 & 1 & 1 & 1 & 1 & 22 & 36 & 1030 \\
\hline \multirow{2}{*}{\multicolumn{13}{|c|}{$\begin{array}{l}\text { Morgan Run 2, Upper Freeport, Kingwood, Undisturbed } \\
1968\end{array}$}} \\
\hline & & & & & & & & & & & & \\
\hline 2000 & 2.5 & 95 & 93 & 13 & 0 & 5 & 1 & 1 & 1 & 130 & 561 & 1290 \\
\hline \multicolumn{13}{|c|}{ Morgan Run 2, Upper Freeport, Kingwood, Undisturbed } \\
\hline 2000 & 3.9 & 28 & 72 & 3 & 9 & 2 & 1 & 13 & 1 & 105 & & 1070 \\
\hline \multicolumn{13}{|c|}{ Morgan Run 4, Upper Freeport, Kingwood, Undisturbed } \\
\hline 2000 & 2.1 & 0 & 588 & 6 & 0 & 93 & 0 & 32 & 11 & 41 & 631 & 2200 \\
\hline
\end{tabular}




\begin{tabular}{|c|c|c|c|c|c|c|c|c|c|c|c|c|}
\hline Year & $\begin{array}{l}\mathrm{pH} \\
\text { (SU) }\end{array}$ & $\begin{array}{l}\text { Flow } \\
\text { (L/min) }\end{array}$ & $\begin{array}{l}\begin{array}{l}\text { Acidity } \\
\text { (mg/L) }\end{array} \\
\end{array}$ & $\begin{array}{l}\text { Acidity } \\
\text { (kg/day) }\end{array}$ & $\begin{array}{l}\text { Alkalinity } \\
\text { (mg/L) }\end{array}$ & $\begin{array}{l}\begin{array}{l}\text { Iron } \\
(\mathrm{mg} / \mathrm{L})\end{array} \\
\end{array}$ & $\begin{array}{l}\text { Iron } \\
\text { (kg/day) }\end{array}$ & $\begin{array}{l}\text { Aluminum } \\
(\mathrm{mg} / \mathrm{L})\end{array}$ & $\begin{array}{l}\text { Manganese } \\
\text { (mg/L) }\end{array}$ & $\begin{array}{l}\text { Calcium } \\
\text { (mg/L) }\end{array}$ & $\begin{array}{l}\begin{array}{l}\text { Sulfate } \\
\text { (mg/L) }\end{array} \\
\end{array}$ & $\begin{array}{l}\text { Conductivity } \\
\text { (umhos/cm) }\end{array}$ \\
\hline \multicolumn{13}{|c|}{ Morgan Run 5, Upper Freeport, Kingwood, Undisturbed } \\
\hline 1968 & & 4 & & 39 & 0 & & 12 & & & & & \\
\hline 2000 & 2.5 & 6 & 459 & 4 & 0 & 18 & 1 & 59 & 15 & 47 & 347 & 1440 \\
\hline \multicolumn{13}{|c|}{ Morgan Run 6, Upper Freeport, Kingwood, Undisturbed } \\
\hline 1968 & & 12 & & & & & & & & & & \\
\hline 2000 & 2.2 & 47 & 597 & 39 & 0 & 112 & 7 & 30 & 2 & 9 & 645 & 1780 \\
\hline \multicolumn{13}{|c|}{ Muddy Creek 1, Upper Freeport, Valley Point, Undisturbed } \\
\hline 1968 & 3.6 & 9 & & & & & & & & & & \\
\hline 1999 & 3.7 & 4 & 145 & 1 & 0 & 1 & 1 & 3 & 1 & 10 & & 160 \\
\hline \multicolumn{13}{|c|}{ Muddy Creek 2, Upper Freeport, Cuzzart, Undisturbed } \\
\hline 1968 & 2.8 & 317 & 687 & 305 & 0 & 116 & 52 & 14 & & & 1878 & 2425 \\
\hline 1980 & 2.1 & 1 & 1200 & 1 & 0 & 120 & 1 & & 1 & & 100 & 1700 \\
\hline \multicolumn{13}{|c|}{ Muddy Creek 3, Upper Freeport, Cuzzart, Disturbed } \\
\hline 1968 & 3.3 & 4 & 170 & 1 & 0 & 1 & 0 & 6 & & & 377 & 876 \\
\hline 2000 & 5.3 & 30 & 45 & 2 & 30 & 0 & 1 & 1 & 1 & 32 & 111 & 2200 \\
\hline \multicolumn{13}{|c|}{ Muddy Creek 4, Upper Freeport, Cuzzart, Surface Disturbed } \\
\hline 1968 & 5.8 & 8 & & & 35 & 1 & 0 & 6 & & & 455 & 966 \\
\hline 2000 & 5.6 & 4 & 108 & 1 & 92 & 4 & 1 & 1 & 2 & 166 & 703 & 1230 \\
\hline \multicolumn{13}{|c|}{ Muddy Creek 5, Lower Freeport, Cuzzart, Undisturbed } \\
\hline 1968 & 6.5 & 4 & 20 & 0 & 150 & 8 & 1 & 1 & & & 13 & 122 \\
\hline 2000 & 5.5 & 4 & 30 & 1 & 15 & 7 & 1 & 1 & 1 & 8 & 39 & 600 \\
\hline \multicolumn{13}{|c|}{ Muddy Creek 6, Upper Freeport, Cuzzart, Undisturbed } \\
\hline 1968 & 2.7 & 11 & 4400 & 70 & 0 & 110 & 2 & 266 & & & 6045 & 4900 \\
\hline 2000 & 4.5 & 4 & 92 & 1 & 25 & 5 & 1 & 1 & 5 & 35 & 147 & 3300 \\
\hline \multicolumn{13}{|c|}{ Muddy Creek 7, Bakerstown, Cuzzart, Disturbed } \\
\hline 1968 & 3.1 & 158 & 520 & 115 & 0 & 86.6 & 19 & & & & 1300 & 2240 \\
\hline 2000 & 5.2 & 8 & 7 & 1 & & 0 & 0 & 1 & 1 & 8 & 15 & 400 \\
\hline \multicolumn{13}{|c|}{ Muddy Creek 8, Upper Freeport, Cuzzart, Undisturbed } \\
\hline 1968 & 7.4 & 8 & 565 & 6 & 15 & 63 & 1 & 41 & & & 41 & 1349 \\
\hline 2000 & 6.6 & 4 & 23 & 1 & 9 & 1 & 0 & 1 & 3 & 15 & 34 & \\
\hline \multicolumn{13}{|c|}{ Muddy Creek 9, Upper Freeport, Valley Point, Disturbed } \\
\hline 1968 & 2.9 & 102 & 1515 & 216 & 0 & 422 & 60 & 301 & & & 1951 & 2687 \\
\hline 1980 & 2.2 & 1 & 1225 & 3 & 0 & 80 & 1 & & 20 & & 2200 & 3310 \\
\hline
\end{tabular}




\begin{tabular}{|c|c|c|c|c|c|c|c|c|c|c|c|c|}
\hline Year & $\begin{array}{l}\mathrm{pH} \\
\text { (SU) }\end{array}$ & $\begin{array}{l}\begin{array}{l}\text { Flow } \\
\text { (L/min) }\end{array} \\
\end{array}$ & $\begin{array}{l}\begin{array}{l}\text { Acidity } \\
\text { (mg/L) }\end{array} \\
\end{array}$ & $\begin{array}{l}\text { Acidity } \\
\text { (kg/day) }\end{array}$ & $\begin{array}{l}\text { Alkalinity } \\
\text { (mg/L) }\end{array}$ & $\begin{array}{l}\begin{array}{l}\text { Iron } \\
(\mathrm{mg} / \mathrm{L})\end{array} \\
\end{array}$ & $\begin{array}{l}\text { Iron } \\
\text { (kg/day) }\end{array}$ & $\begin{array}{l}\text { Aluminum } \\
(\mathrm{mg} / \mathrm{L})\end{array}$ & $\begin{array}{l}\begin{array}{l}\text { Manganese } \\
(\mathrm{mg} / \mathrm{L})\end{array} \\
\end{array}$ & $\begin{array}{l}\begin{array}{l}\text { Calcium } \\
\text { (mg/L) }\end{array} \\
\end{array}$ & $\begin{array}{l}\begin{array}{l}\text { Sulfate } \\
(\mathrm{mg} / \mathrm{L})\end{array} \\
\end{array}$ & $\begin{array}{l}\begin{array}{l}\text { Conductivity } \\
\text { (umhos/cm) }\end{array} \\
\end{array}$ \\
\hline \multicolumn{13}{|c|}{ Muddy Creek 10, Upper Kittanning, Valley Point, Disturbed } \\
\hline 1968 & 2.9 & 68 & 1440 & 137 & 0 & 120 & 11 & 139 & & & 2080 & \\
\hline 1999 & 5.1 & 8 & 87 & 1 & 34 & 13 & 1 & 8 & 2 & 30 & & 160 \\
\hline \multicolumn{13}{|c|}{ Muddy Creek 11, Upper Freeport, Valley Point, Disturbed } \\
\hline 1968 & 2.6 & 1134 & 2140 & 3397 & 0 & 576 & 914 & 108 & & & 2704 & 4002 \\
\hline 1980 & 2.4 & 1 & 634 & 1 & 0 & 85 & 1 & & 1.5 & & 1200 & 2120 \\
\hline \multicolumn{13}{|c|}{ Pringle Run 1, Upper Freeport, Kingwood, Undisturbed } \\
\hline 2000 & 5.6 & 19 & 0 & 0 & 129 & 6 & 1 & 2 & 1 & 62 & 48 & 450 \\
\hline \multicolumn{13}{|c|}{ Pringle Run 2, Upper Freeport, Kingwood, Disturbed } \\
\hline 1968 & & 2 & & & & & & & & & & \\
\hline 2000 & 3.5 & 75 & 236 & 26 & 0 & 6 & 2 & 28 & 2 & 25 & 1387 & 1130 \\
\hline \multicolumn{13}{|c|}{ Pringle Run 3, Upper Freeport, Kingwood, Undisturbed } \\
\hline 2000 & 4.1 & 28 & 0 & 0 & 29 & 4 & 1 & 1 & 2 & 21 & 37 & 170 \\
\hline
\end{tabular}




\section{Appendix D}

ANOVA Results for Flow and Acidity Models for T\&T and Omega 


\section{T\&T ANOVA RESULTS}

\section{Model : Flow Category * Year}

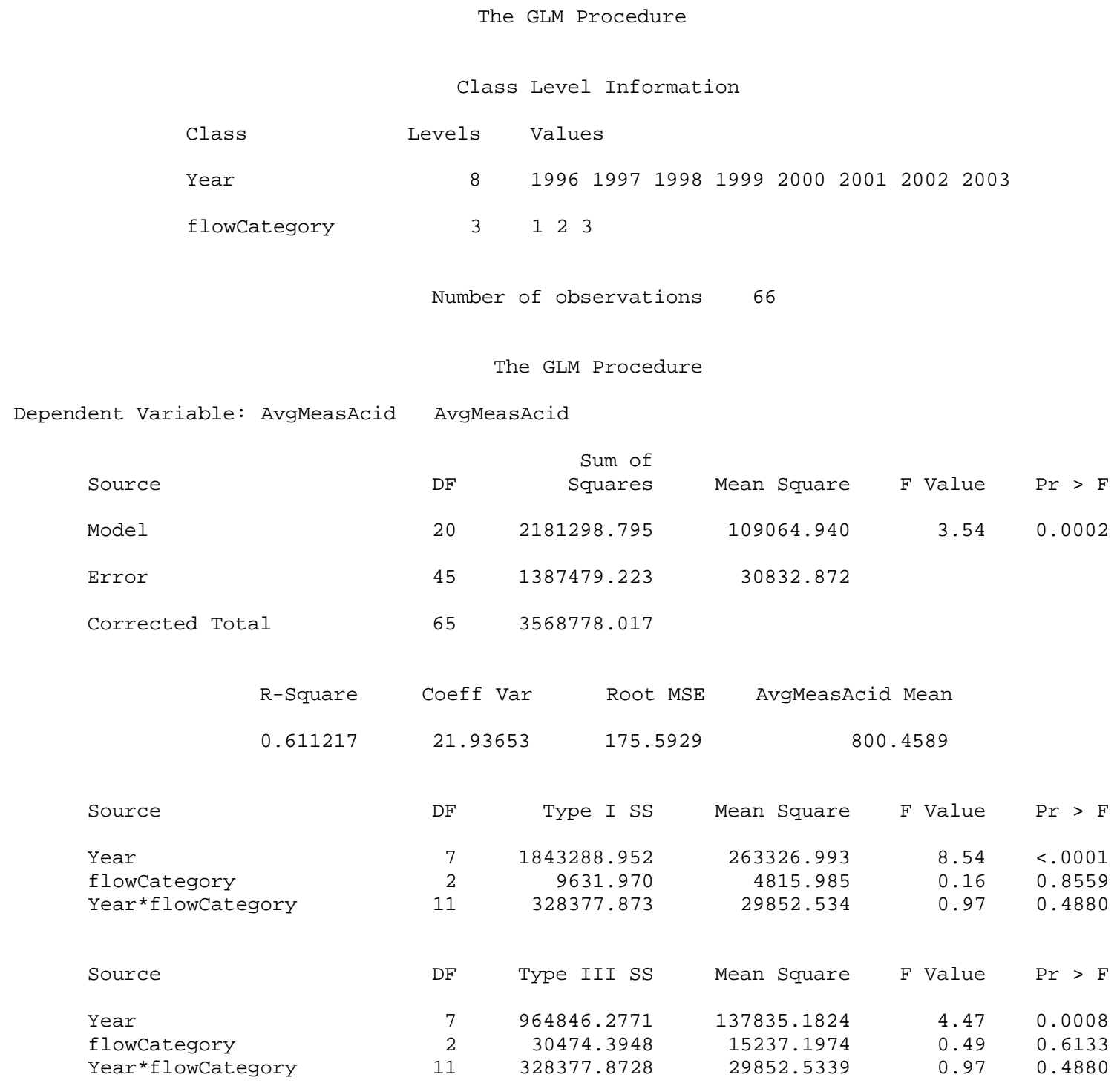


The GLM Procedure

Tukey's Studentized Range (HSD) Test for AvgMeasAcid

NOTE: This test controls the Type I experimentwise error rate, but it generally has a higher Type II error rate than REGWQ.

$\begin{array}{lr}\text { Alpha } & 0.05 \\ \text { Error Degrees of Freedom } & 45 \\ \text { Error Mean Square } & 30832.87 \\ \text { Critical Value of Studentized Range } & 4.49390 \\ \text { Minimum Significant Difference } & 308.5 \\ \text { Harmonic Mean of Cell Sizes } & 6.542751\end{array}$

NOTE: Cell sizes are not equal.

Means with the same letter are not significantly different.

\begin{tabular}{|c|c|c|c|c|c|}
\hline \multirow[t]{2}{*}{ Tukey } & \multicolumn{2}{|c|}{ Grouping } & Mean & $\mathrm{N}$ & Year \\
\hline & \multicolumn{2}{|l|}{ A } & 1127.41 & 6 & 1996 \\
\hline & \multicolumn{2}{|l|}{ A } & & & \\
\hline & \multicolumn{2}{|l|}{ A } & 1054.00 & 3 & 2003 \\
\hline & \multicolumn{2}{|l|}{ A } & & & \\
\hline B & \multicolumn{2}{|l|}{ A } & 914.43 & 11 & 1997 \\
\hline B & \multicolumn{2}{|l|}{ A } & & & \\
\hline B & \multirow[t]{2}{*}{ A } & $\mathrm{C}$ & 871.37 & 11 & 2000 \\
\hline B & & $\mathrm{C}$ & & & \\
\hline B & & $\mathrm{C}$ & 736.32 & 11 & 1999 \\
\hline B & $B$ & $\mathrm{C}$ & & & \\
\hline B & & $\mathrm{C}$ & 700.15 & 10 & 1998 \\
\hline & & $\mathrm{C}$ & & & \\
\hline & & $\mathrm{C}$ & 589.56 & 10 & 2001 \\
\hline & & $\mathrm{C}$ & & & \\
\hline & & $\mathrm{C}$ & 565.84 & 4 & 2002 \\
\hline
\end{tabular}

The GLM Procedure

Tukey's Studentized Range (HSD) Test for AvgMeasAcid

NOTE: This test controls the Type I experimentwise error rate, but it generally has a higher Type II error rate than REGWQ.

$\begin{array}{lr}\text { Alpha } & 0.05 \\ \text { Error Degrees of Freedom } & 45 \\ \text { Error Mean Square } & 30832.87 \\ \text { Critical Value of Studentized Range } & 3.42751 \\ \text { Minimum Significant Difference } & 128.9 \\ \text { Harmonic Mean of Cell Sizes } & 21.79931\end{array}$

NOTE: Cell sizes are not equal.

Means with the same letter are not significantly different.

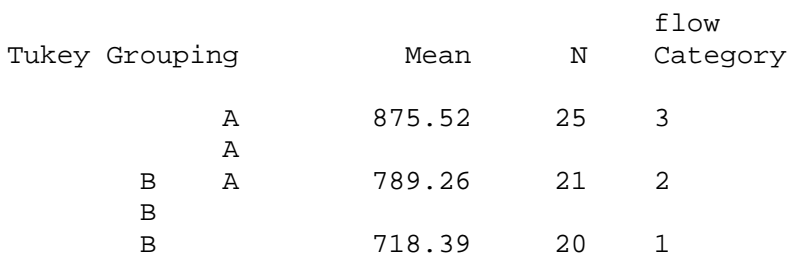

D-2 
Model: Flow Category * Year* Season

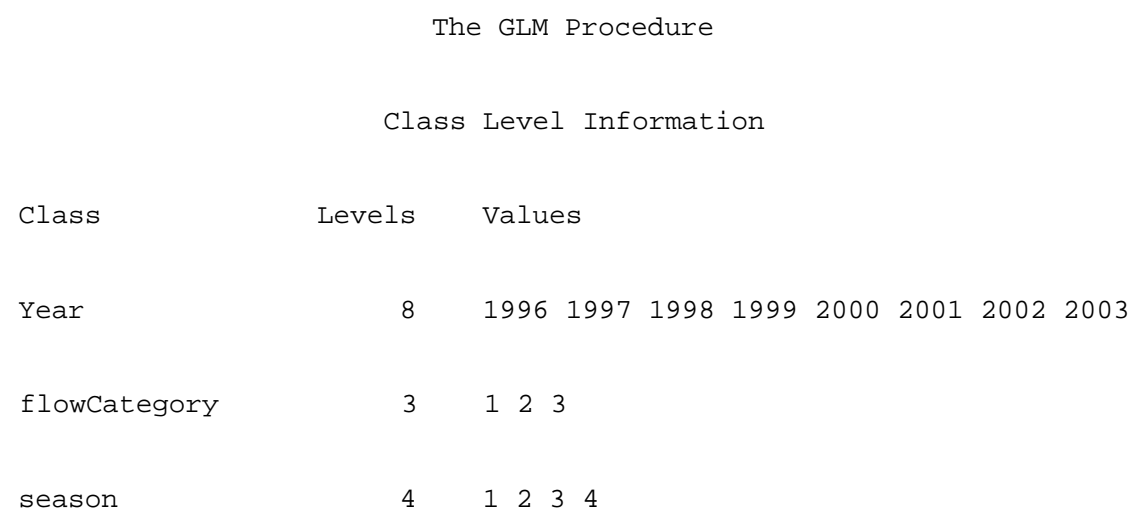

Number of observations 66

The GLM Procedure

Dependent Variable: AvgMeasAcid AvgMeasAcid

\begin{tabular}{|c|c|c|c|c|c|}
\hline Source & $\mathrm{DF}$ & Squares & Mean Square & F Value & $\operatorname{Pr}>\mathrm{F}$ \\
\hline Model & 38 & 953894.248 & 77734.059 & 3.41 & 0.0007 \\
\hline Error & 27 & 614883.769 & 22773.473 & & \\
\hline Corrected Total & 65 & 568778.017 & & & \\
\hline R-Square & Coeff Var & Root MSE & AvgMeasAcid & Mean & \\
\hline 0.827705 & 18.85279 & 150.9088 & 800 . & 4589 & \\
\hline Source & $\mathrm{DF}$ & Type I SS & Mean Square & F Value & $\operatorname{Pr}>\mathrm{F}$ \\
\hline Year & 18 & 843288.952 & 263326.993 & 11.56 & $<.0001$ \\
\hline flowCategory & 2 & 9631.970 & 4815.985 & 0.21 & 0.8107 \\
\hline Year*flowCategory & 11 & 328377.873 & 29852.534 & 1.31 & 0.2714 \\
\hline season & 3 & 57951.276 & 19317.092 & 0.85 & 0.4797 \\
\hline Year*season & 13 & 702366.747 & 54028.211 & 2.37 & 0.0282 \\
\hline flowCategory*season & 2 & 12277.431 & 6138.715 & 0.27 & 0.7657 \\
\hline Year*flowCate*season & 0 & 0.000 & . & . & . \\
\hline
\end{tabular}




$\begin{array}{lrrrrr}\text { Source } & \text { DF } & \text { Type III SS } & \text { Mean Square } & \text { F Value } & \text { Pr }>\text { F } \\ & & & & & \\ \text { Year } & 7 & 639977.7947 & 91425.3992 & 4.01 & 0.0039 \\ \text { flowCategory } & 2 & 121.2639 & 60.6320 & 0.00 & 0.9973 \\ \text { Year*flowCategory } & 5 & 140639.3247 & 28127.8649 & 1.24 & 0.3202 \\ \text { season } & 3 & 195841.4943 & 65280.4981 & 2.87 & 0.0551 \\ \text { Year*season } & 10 & 264360.3880 & 26436.0388 & 1.16 & 0.3577 \\ \text { flowCategory*season } & 2 & 12277.4307 & 6138.7153 & 0.27 & 0.7657 \\ \text { Year*flowCate*season } & 0 & 0.0000 & & . & . \\ \text { - } & & & & & \end{array}$

NOTE: This test controls the Type I experimentwise error rate, but it generally has a higher Type II error rate than REGWQ.

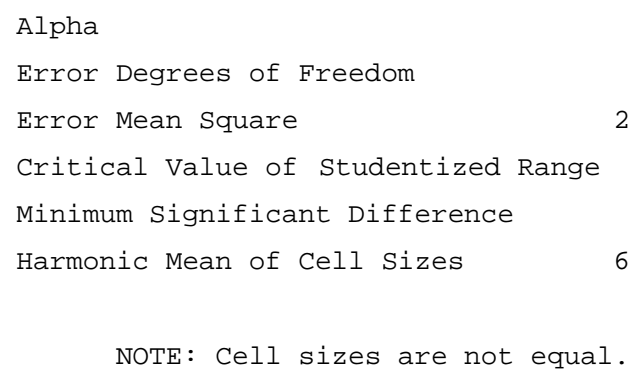

Means with the same letter are not significantly different.

\begin{tabular}{|c|c|c|c|c|c|}
\hline Tukey & Grou & & Mean & $\mathrm{N}$ & Year \\
\hline & & A & 1127.41 & 6 & 1996 \\
\hline & & A & & & \\
\hline & & A & 1054.00 & 3 & 2003 \\
\hline & & A & & & \\
\hline & B & A & 914.43 & 11 & 1997 \\
\hline & B & A & & & \\
\hline & B & A & 871.37 & 11 & 2000 \\
\hline & B & & & & \\
\hline & B & $\mathrm{C}$ & 736.32 & 11 & 1999 \\
\hline & B & $\mathrm{C}$ & & & \\
\hline & B & $\mathrm{C}$ & 700.15 & 10 & 1998 \\
\hline & & $\mathrm{C}$ & & & \\
\hline & & $\mathrm{C}$ & 589.56 & 10 & 2001 \\
\hline & & $\mathrm{C}$ & & & \\
\hline & & $\mathrm{C}$ & 565.84 & 4 & 2002 \\
\hline
\end{tabular}


NOTE: This test controls the Type I experimentwise error rate, but it generally has a higher Type II error rate than REGWQ.

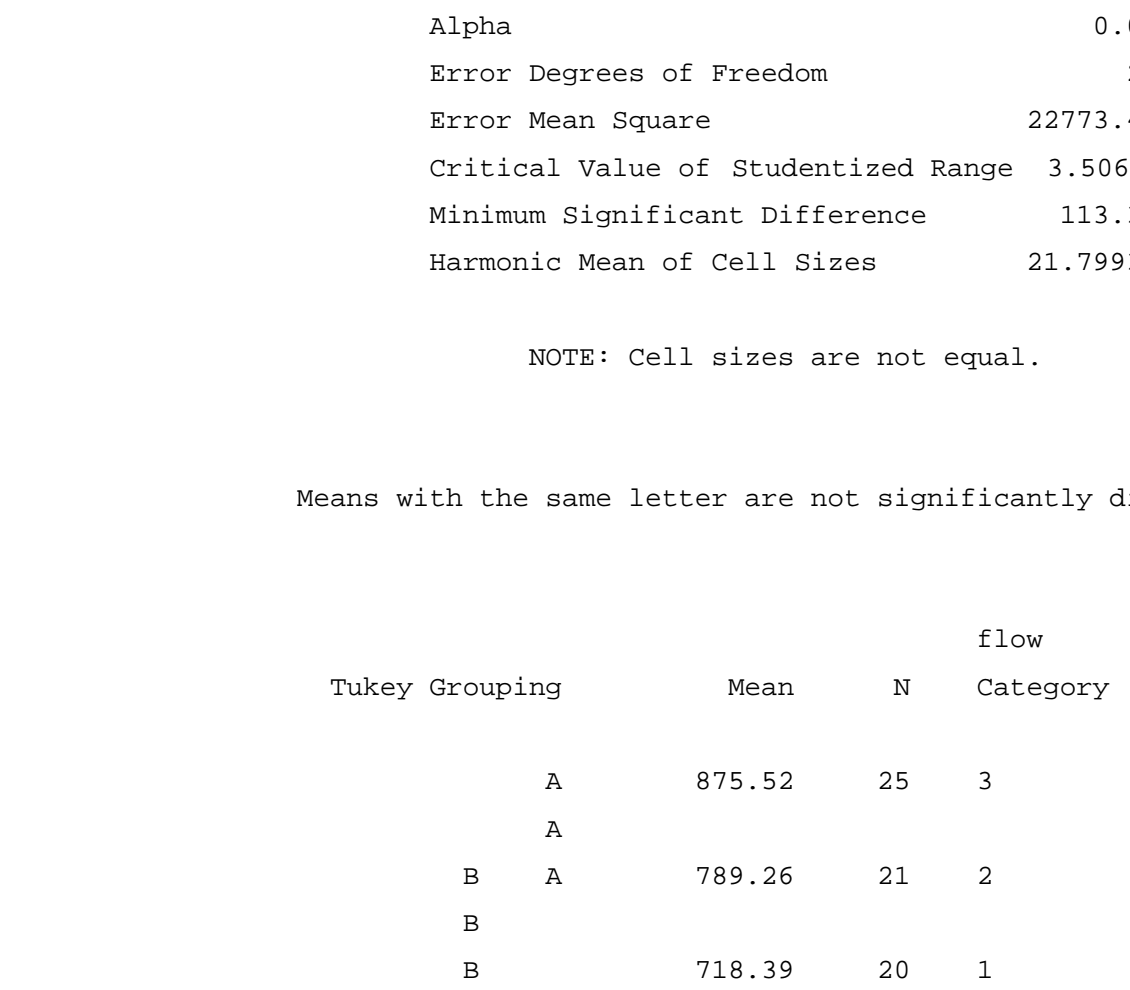

The GLM Procedure

Tukey's Studentized Range (HSD) Test for AvgMeasAcid

NOTE: This test controls the Type I experimentwise error rate, but it generally has a higher Type II error rate than REGWQ.

$\begin{array}{lr}\text { Alpha } & 0.05 \\ \text { Error Degrees of Freedom } & 27 \\ \text { Error Mean Square } & 22773.47 \\ \text { Critical Value of Studentized Range } & 3.87009 \\ \text { Minimum Significant Difference } & 146.41 \\ \text { Harmonic Mean of Cell Sizes } & 15.9116\end{array}$




$\begin{array}{rrrr}\text { Means with the same letter are not significant } & & \\ & & & \\ \text { Tukey Grouping } & \text { Mean } & \text { N } & \text { season } \\ \text { A } & 813.28 & 20 & 1 \\ \text { A } & & & \\ \text { A } & 811.40 & 12 & 3 \\ \text { A } & & & \\ \text { A } & 805.43 & 18 & 2 \\ \text { A } & & 16 & 4 \\ \text { A } & 770.63 & 16\end{array}$

\section{Model: Average Flow * Year}

The GLM Procedure

Dependent Variable: AvgMeasAcid AvgMeasAcid

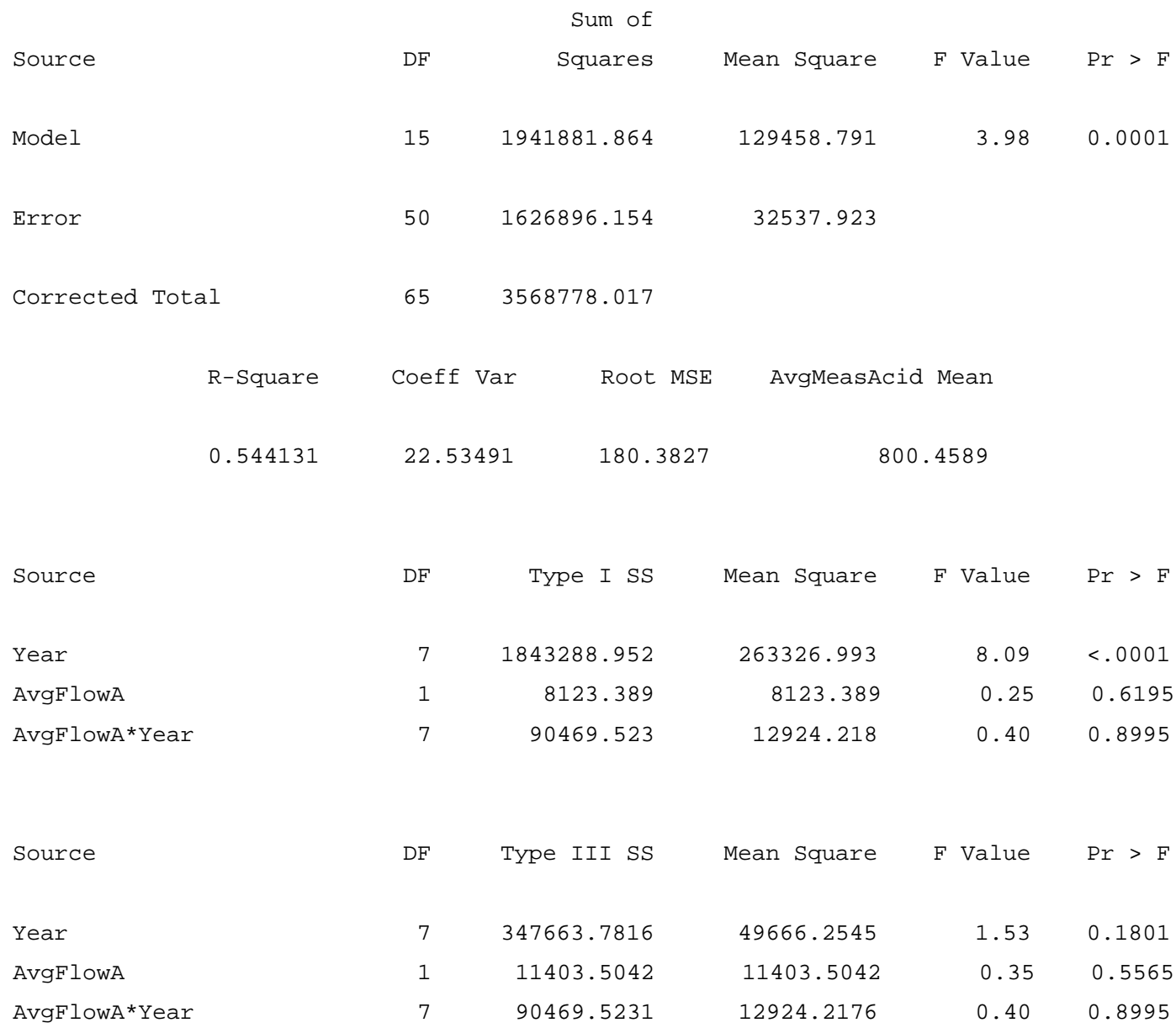


The GLM Procedure

Tukey's Studentized Range (HSD) Test for AvgMeasAcid

NOTE: This test controls the Type I experimentwise error rate, but it generally has a higher Type II error rate than REGWQ.

$\begin{array}{lr}\text { Alpha } & 0.05 \\ \text { Error Degrees of Freedom } & 50 \\ \text { Error Mean Square } & 32537.92 \\ \text { Critical Value of Studentized Range } & 4.47270 \\ \text { Minimum Significant Difference } & 315.42 \\ \text { Harmonic Mean of Cell Sizes } & 6.542751\end{array}$

NOTE: Cell sizes are not equal.

Means with the same letter are not significantly different.

\begin{tabular}{|c|c|c|c|c|c|}
\hline Tukey & Grol & & Mean & $\mathrm{N}$ & Year \\
\hline & A & & 1127.41 & 6 & 1996 \\
\hline & A & & & & \\
\hline & A & & 1054.00 & 3 & 2003 \\
\hline & A & & & & \\
\hline B & A & & 914.43 & 11 & 1997 \\
\hline B & A & & & & \\
\hline B & A & $\mathrm{C}$ & 871.37 & 11 & 2000 \\
\hline B & & $\mathrm{C}$ & & & \\
\hline B & & $\mathrm{C}$ & 736.32 & 11 & 1999 \\
\hline B & & $\mathrm{C}$ & & & \\
\hline B & & $\mathrm{C}$ & 700.15 & 10 & 1998 \\
\hline & & $\mathrm{C}$ & & & \\
\hline & & $\mathrm{C}$ & 589.56 & 10 & 2001 \\
\hline & & $\mathrm{C}$ & & & \\
\hline & & $\mathrm{C}$ & 565.84 & 4 & 2002 \\
\hline
\end{tabular}




\section{Model: Average Flow * Year ${ }^{*}$ Season}

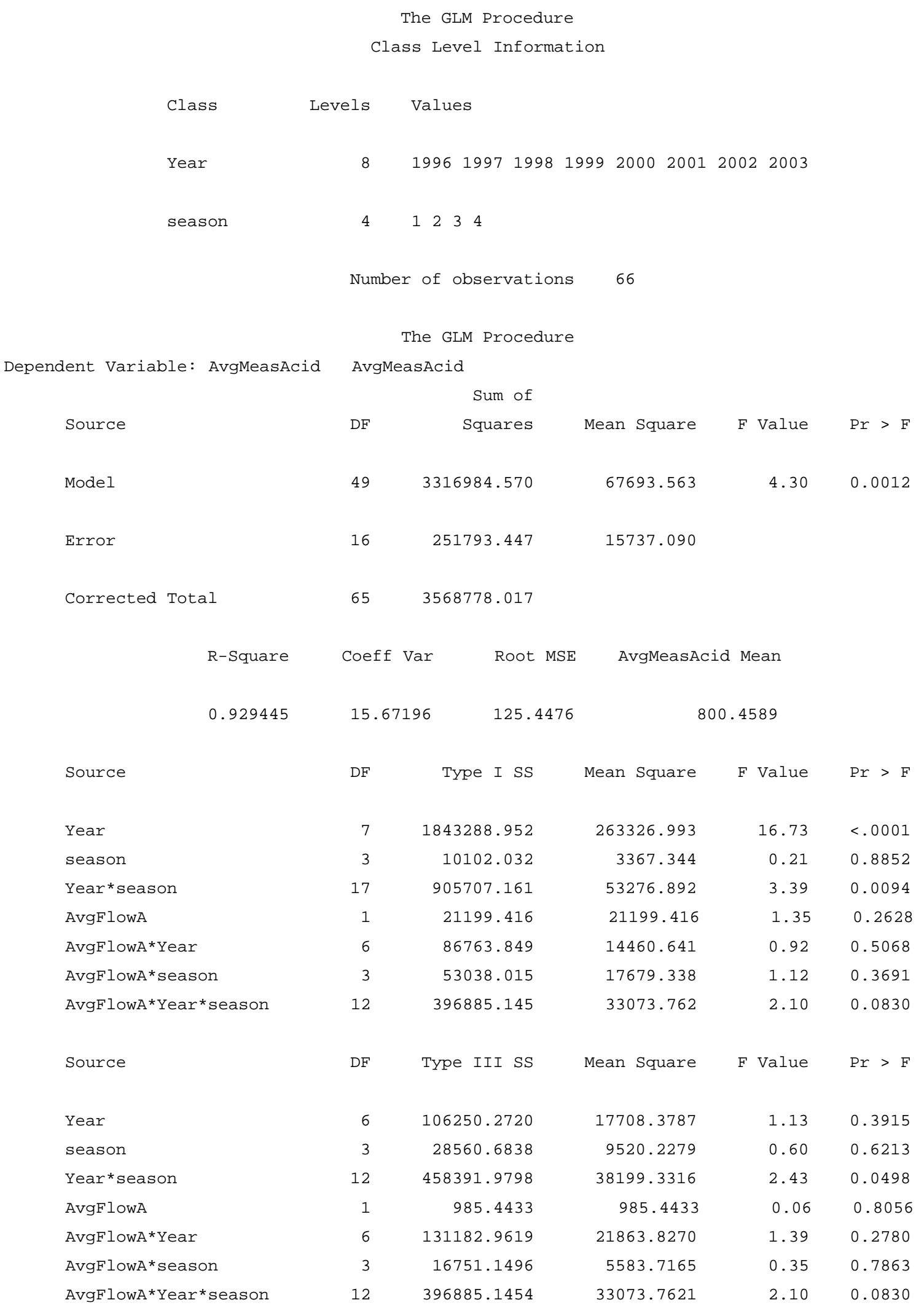


The GLM Procedure

Tukey's Studentized Range (HSD) Test for AvgMeasAcid

NOTE: This test controls the Type I experimentwise error rate, but it generally has a higher Type II error rate than REGWQ.

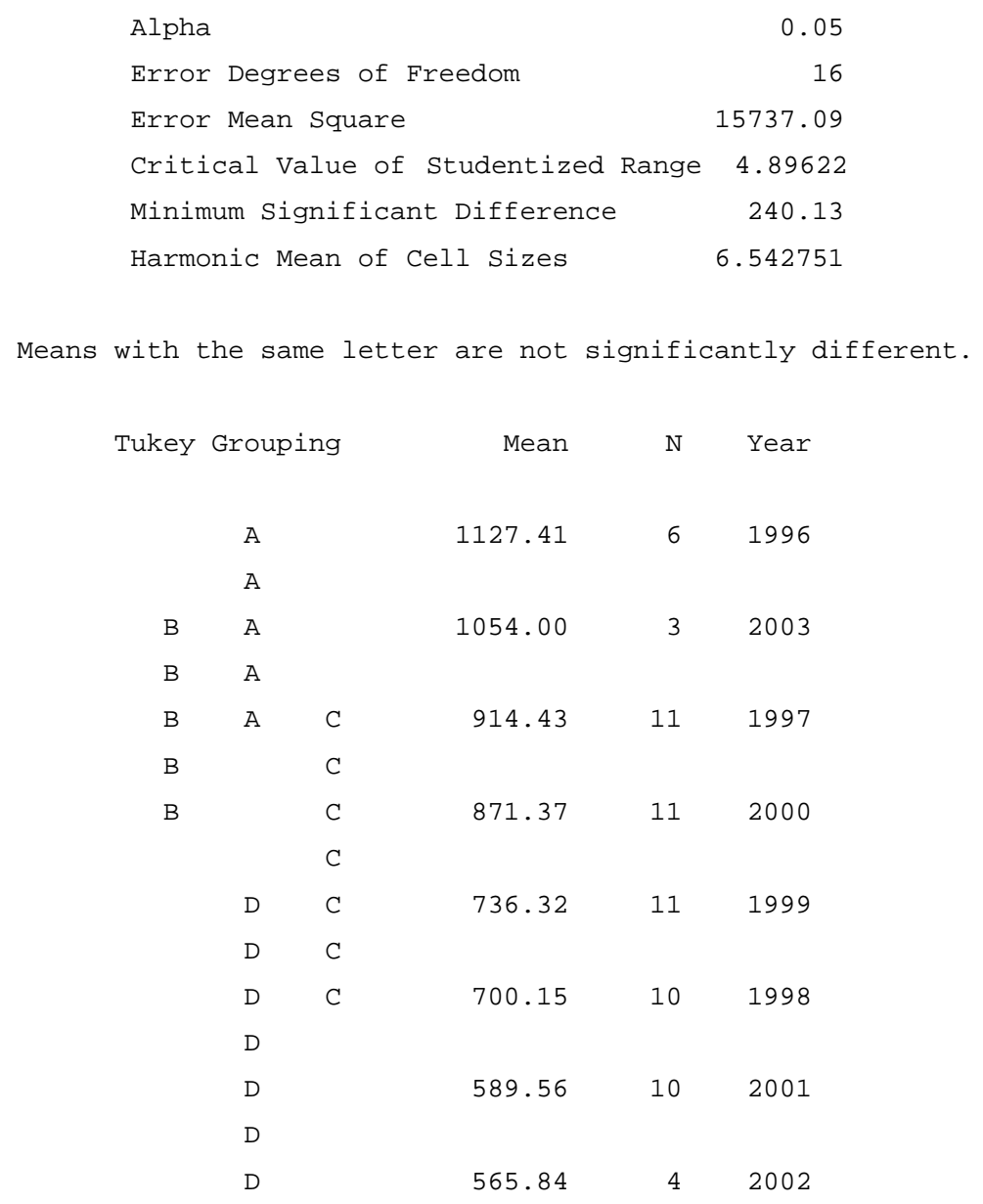

The GLM Procedure

Tukey's Studentized Range (HSD) Test for AvgMeasAcid

NOTE: This test controls the Type I experimentwise error rate, but it generally has a higher Type II error rate than REGWQ.

$\begin{array}{lr}\text { Alpha } & 0.05 \\ \text { Error Degrees of Freedom } & 16 \\ \text { Error Mean Square } & 15737.09 \\ \text { Critical Value of Studentized Range } & 4.04609 \\ \text { Minimum Significant Difference } & 127.25 \\ \text { Harmonic Mean of Cell Sizes } & 15.9116\end{array}$


Means with the same letter are not significantly different.

$\begin{array}{crrr}\text { Tukey Grouping } & \text { Mean } & \text { N } & \text { se } \\ \text { A } & 813.28 & 20 & 1 \\ \text { A } & & & \\ \text { A } & 811.40 & 12 & 3 \\ \text { A } & & & \\ \text { A } & 805.43 & 18 & 2 \\ \text { A } & & & \\ \text { A } & 770.63 & 16 & 4\end{array}$

\section{Model: Average Flow * Month}

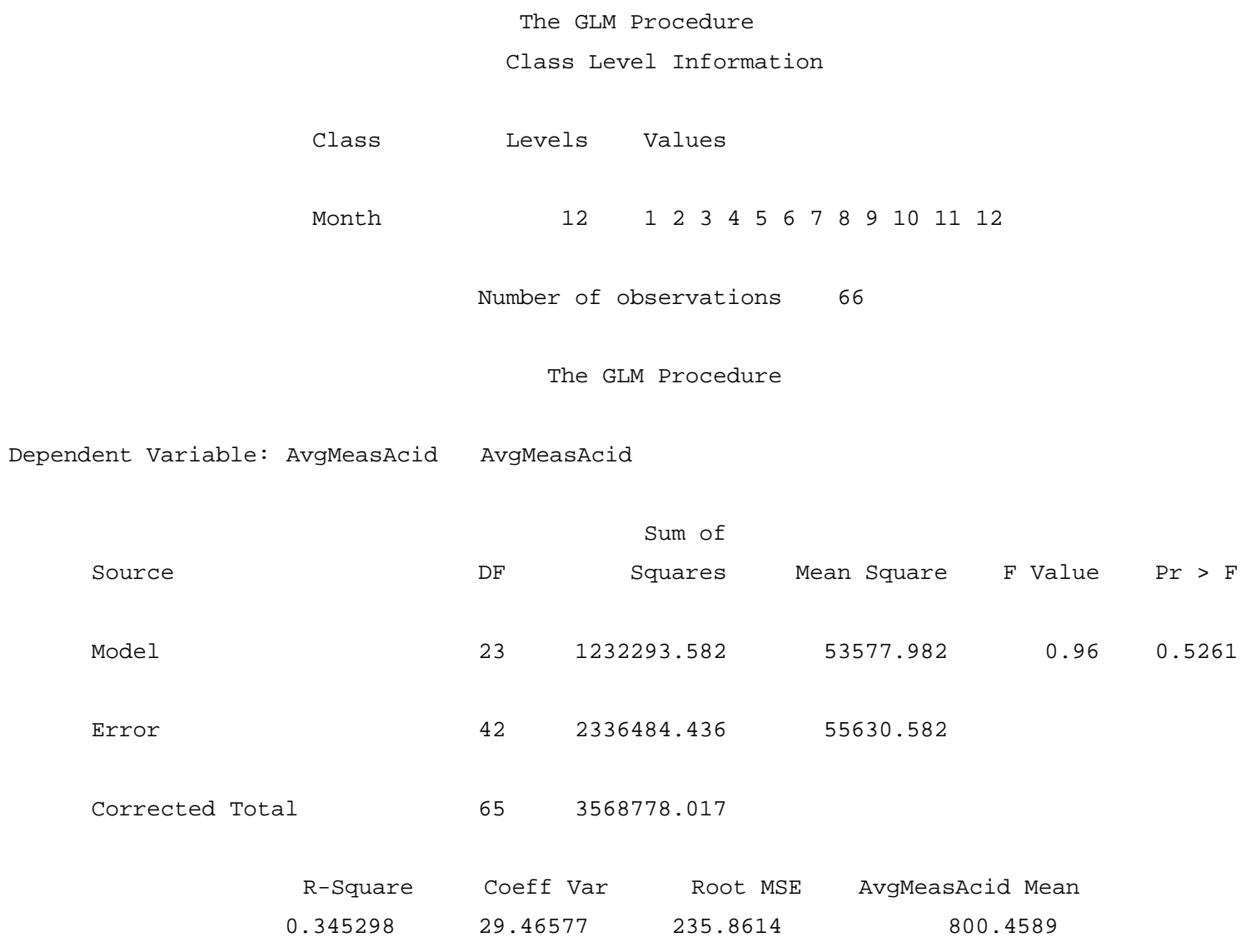




$\begin{array}{lrrrrr}\text { Source } & \text { DF } & \text { Type I SS } & \text { Mean Square } & \text { F Value } & \text { Pr }>\text { F } \\ \text { Month } & 11 & 124383.9548 & 11307.6323 & 0.20 & 0.9965 \\ \text { AvgFlowA } & 1 & 631212.9196 & 631212.9196 & 11.35 & 0.0016 \\ \text { AvgFlowA*Month } & 11 & 476696.7072 & 43336.0643 & 0.78 & 0.6587 \\ & & & & & \\ \text { Source } & \text { DF } & \text { Type III SS } & \text { Mean Square } & \text { F Value } & \text { Pr F } \\ \text { Month } & 11 & 326589.4775 & 29689.9525 & 0.53 & 0.8691 \\ \text { AvgFlowA } & 1 & 441620.8258 & 441620.8258 & 7.94 & 0.0073 \\ \text { AvgFlowA*Month } & 11 & 476696.7072 & 43336.0643 & 0.78 & 0.6587\end{array}$

The GLM Procedure

Tukey's Studentized Range (HSD) Test for AvgMeasAcid

NOTE: This test controls the Type I experimentwise error rate, but it generally has a higher Type II error rate than REGWQ.

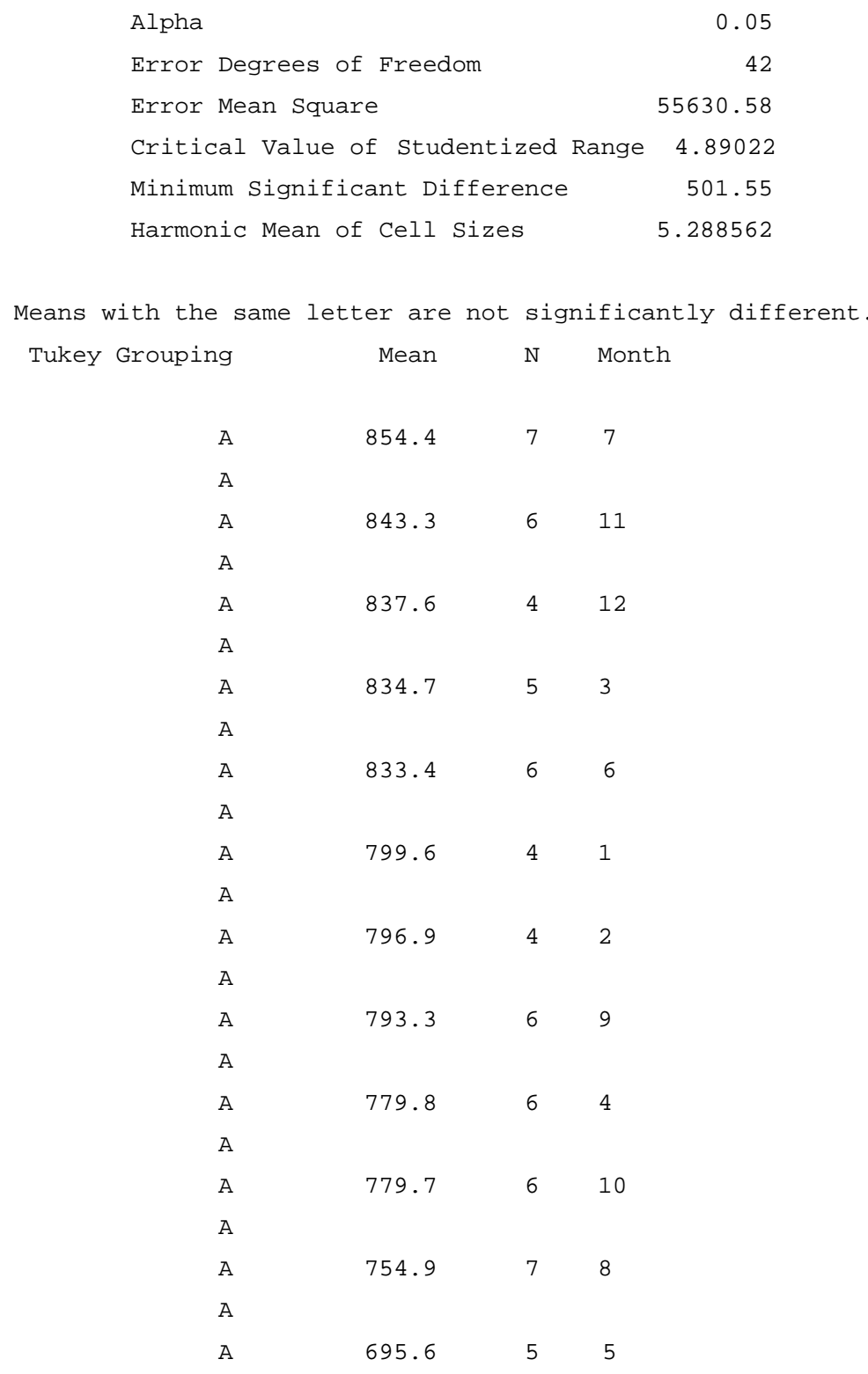




\section{Model: Flow Category * Average Precipitation}

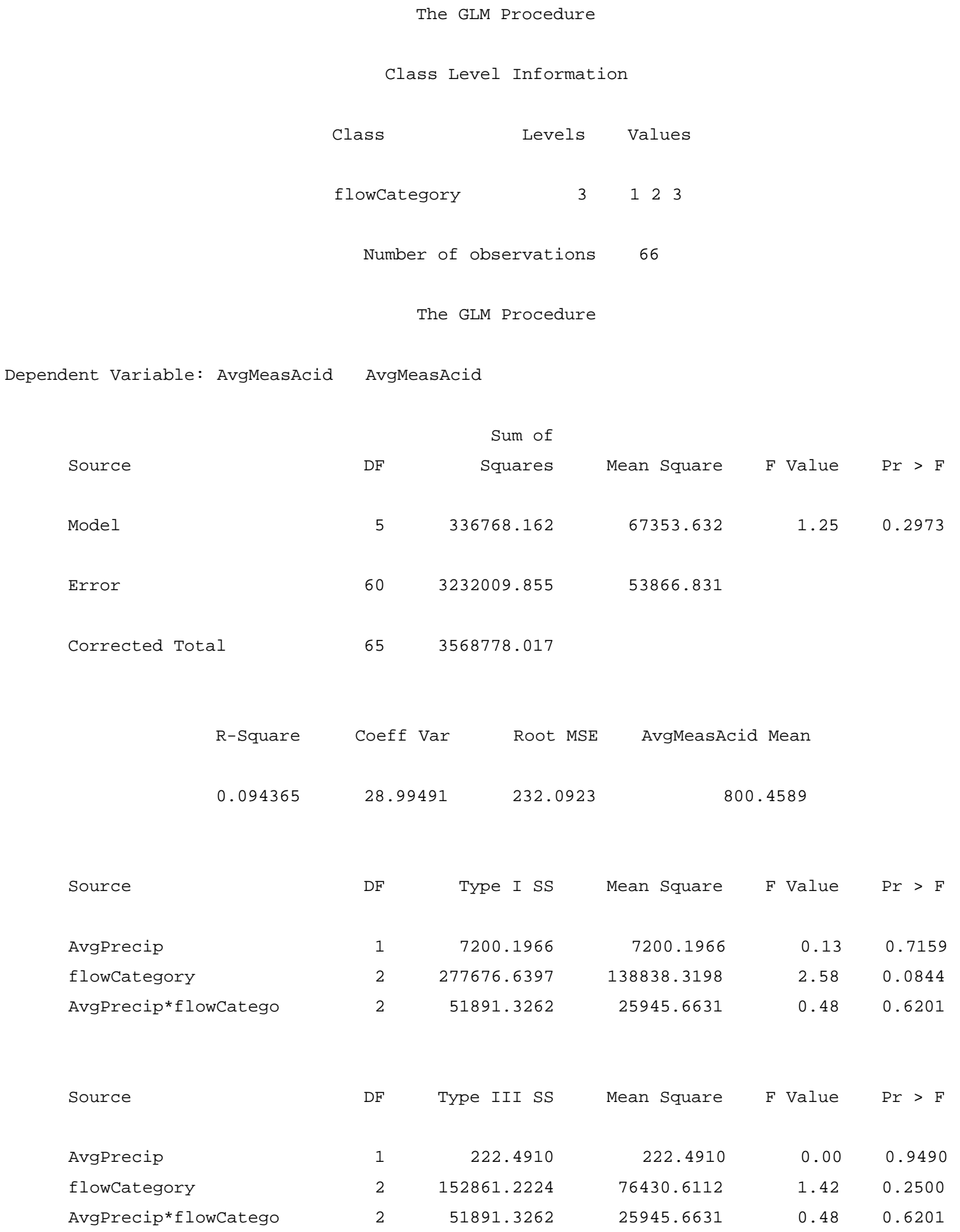


The GLM Procedure

Tukey's Studentized Range (HSD) Test for AvgMeasAcid

NOTE: This test controls the Type I experimentwise error rate, but it generally has a higher Type II error rate than REGWQ.

$\begin{array}{lr}\text { Alpha } & 0.05 \\ \text { Error Degrees of Freedom } & 60 \\ \text { Error Mean Square } & 53866.83 \\ \text { Critical Value of Studentized Range } & 3.39867 \\ \text { Minimum Significant Difference } & 168.95 \\ \text { Harmonic Mean of Cell Sizes } & 21.79931 \\ \text { Note: Cell sizes are not equal. }\end{array}$

Means with the same letter are not significantly different.

$\begin{array}{lll} & & \text { flow } \\ \text { Tukey Grouping } & \text { Mean } \quad N \quad \text { Category }\end{array}$

A $\quad 875.52 \quad 25-30-3$

A

A $\quad 789.26 \quad 21 \quad 2$

A

A $\quad 718.39 \quad 20 \quad 1$

\section{Model: Average Flow * Average Precipitation}

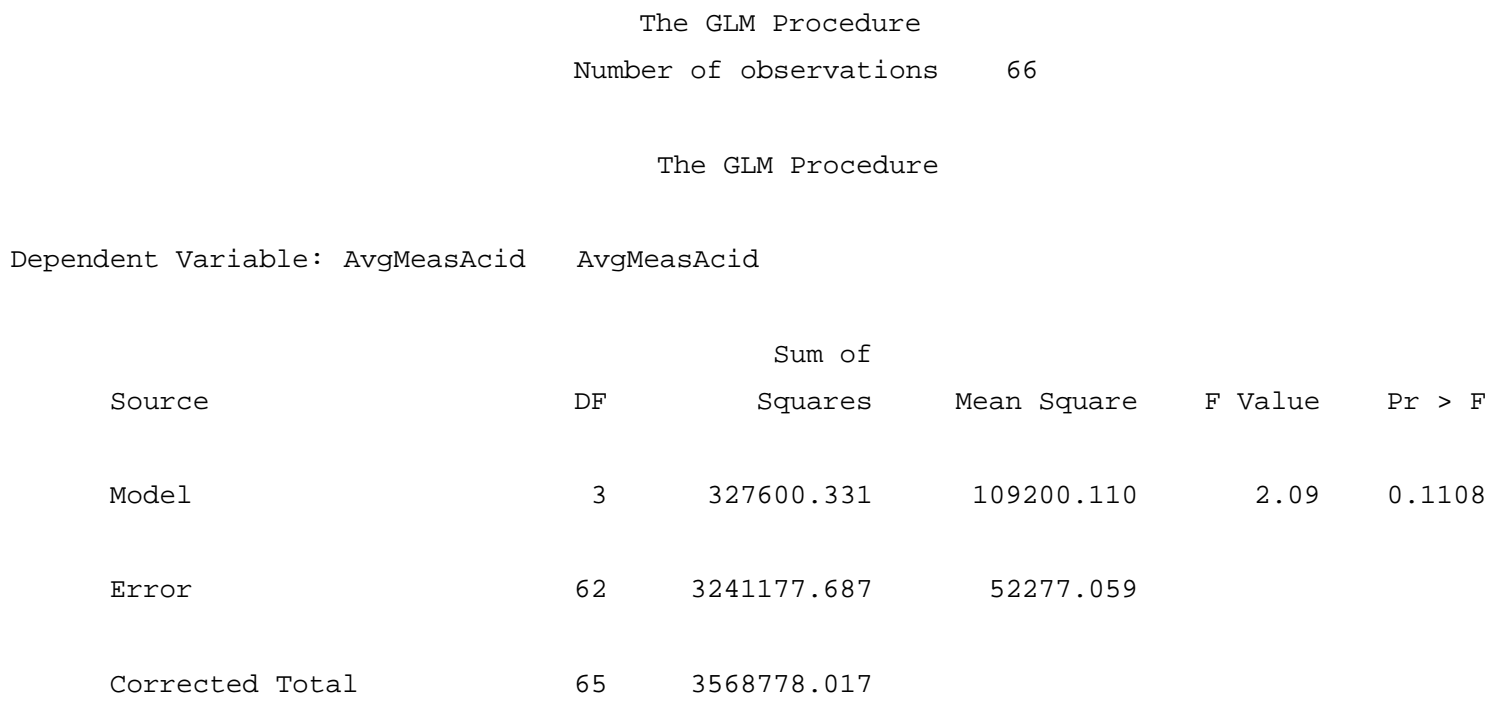




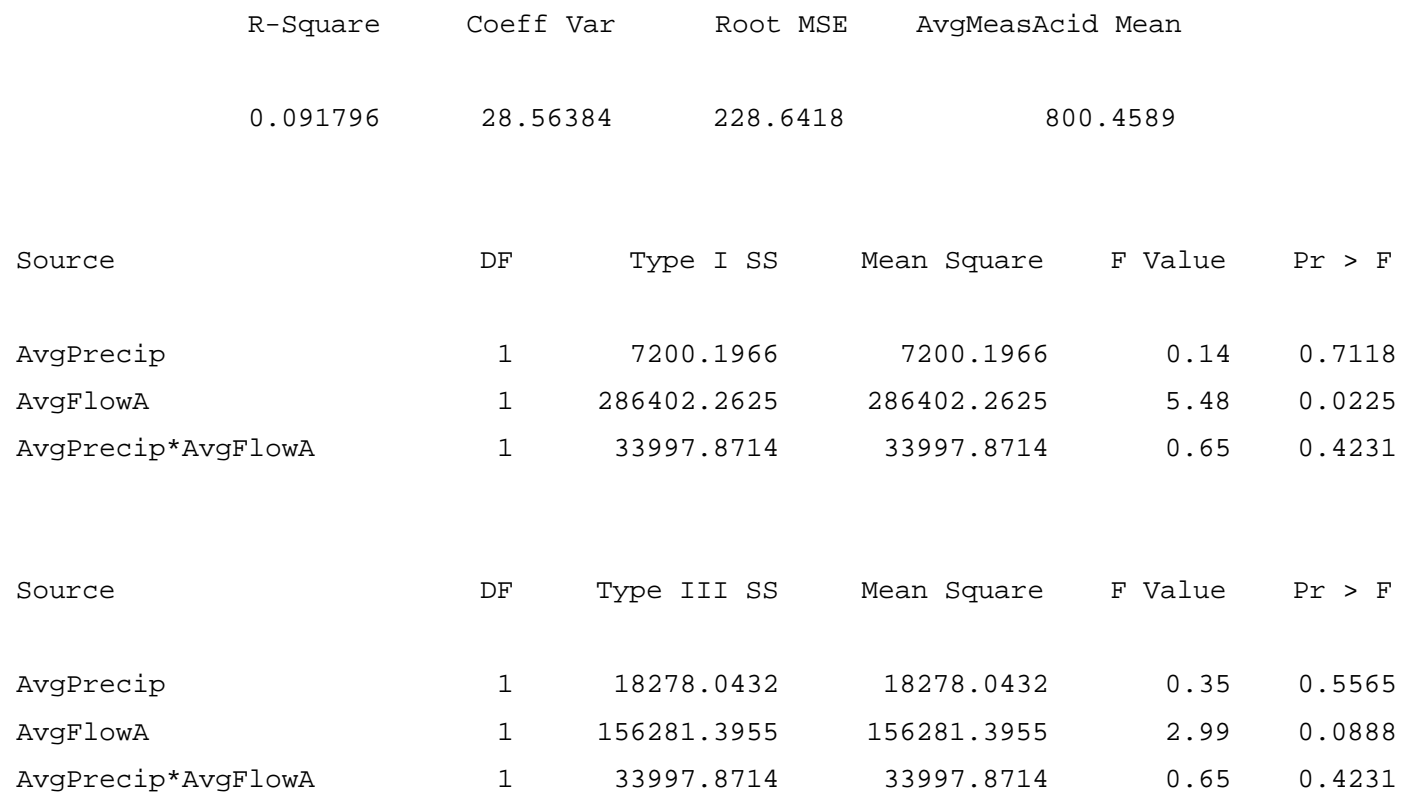

\section{Omega ANOVA Results}

\section{Model: Flow Category * Year}

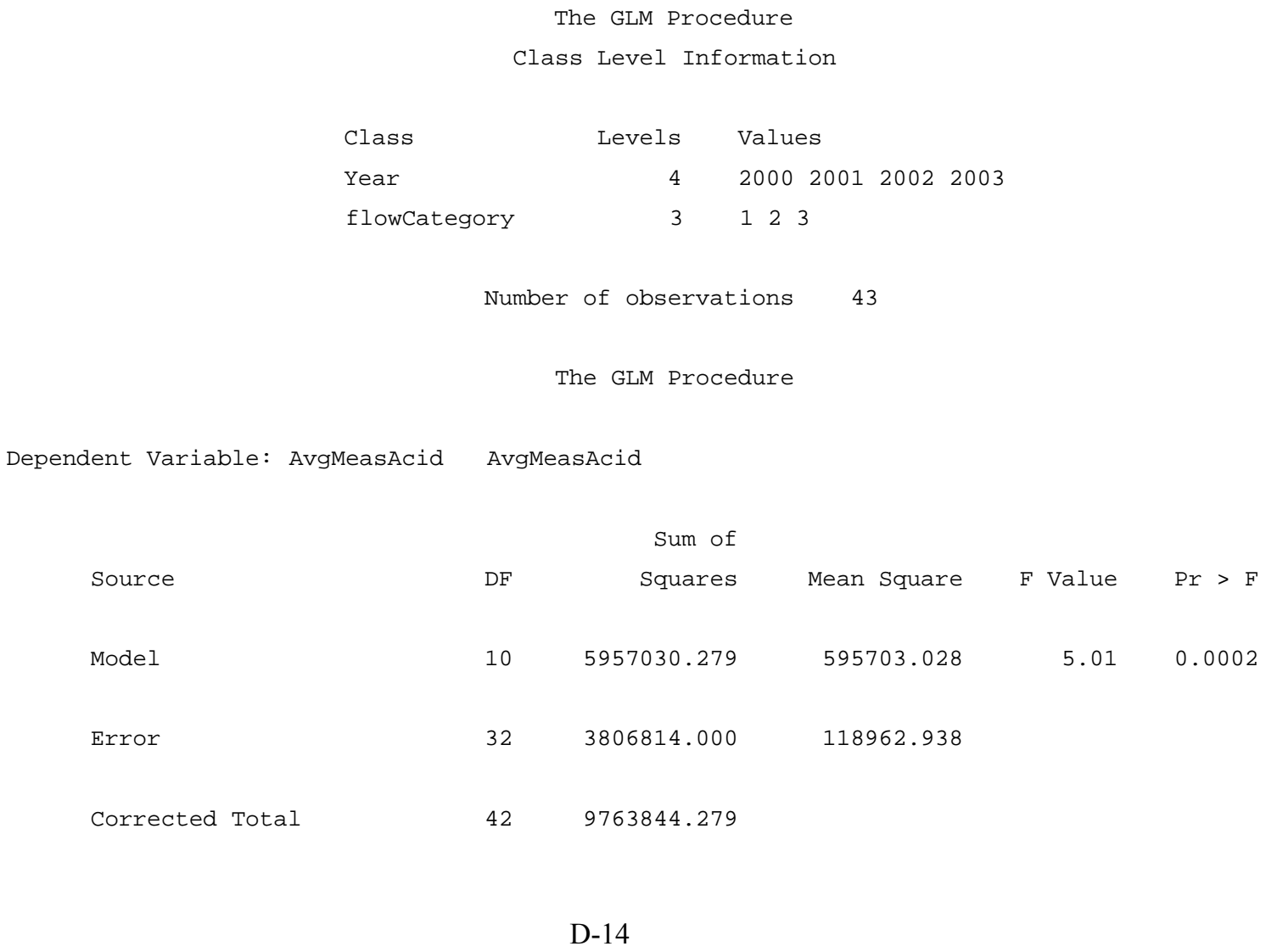




$\begin{array}{lrrr}\text { R-Square } & \text { Coeff Var } & \text { Root MSE } & \text { AvgMeasAcid Mean } \\ 0.610111 & 26.64211 & 344.9100 & 1294.605\end{array}$

\begin{tabular}{|c|c|c|c|c|c|c|}
\hline Source & $\mathrm{DF}$ & Type I SS & Mean Square & $\mathrm{F}$ & Value & $\operatorname{Pr}>\mathrm{F}$ \\
\hline Year & 3 & 3453391.370 & 1151130.457 & & 9.68 & 0.0001 \\
\hline flowCategory & 2 & 533259.955 & 266629.977 & & 2.24 & 0.1228 \\
\hline Year*flowCategory & 5 & 1970378.955 & 394075.791 & & 3.31 & 0.0160 \\
\hline Source & $\mathrm{DF}$ & Type III SS & Mean Square & $\mathrm{F}$ & Value & $\operatorname{Pr}>\mathrm{F}$ \\
\hline Year & 3 & 2956390.655 & 985463.552 & & 8.28 & 0.0003 \\
\hline flowCategory & 2 & 554725.836 & 277362.918 & & 2.33 & 0.1134 \\
\hline Year*flowCategory & 5 & 1970378.955 & 394075.791 & & 3.31 & 0.0160 \\
\hline
\end{tabular}

The GLM Procedure

Tukey's Studentized Range (HSD) Test for AvgMeasAcid

NOTE: This test controls the Type I experimentwise error rate, but it generally has a higher Type II error rate than REGWQ.

$\begin{array}{lr}\text { Alpha } & 0.05 \\ \text { Error Degrees of Freedom } & 32 \\ \text { Error Mean Square } & 118962.9 \\ \text { Critical Value of Studentized Range } & 3.83162 \\ \text { Minimum Significant Difference } & 403.42 \\ \text { Harmonic Mean of Cell Sizes } & 10.73171 \\ & \end{array}$

$\begin{array}{rrrr}\text { Tukey Grouping } & \text { Mean } & \text { N } & \text { Year } \\ \text { A } & 1616.4 & 11 & 2000 \\ \text { A } & & & \\ \text { A } & 1515.5 & 11 & 2001 \\ \text { B } & 1069.8 & 11 & 2003 \\ \text { B } & & & \\ \text { B } & 945.0 & 10 & 2002\end{array}$


The GLM Procedure

Dependent Variable: AvgMeasAcid AvgMeasAcid

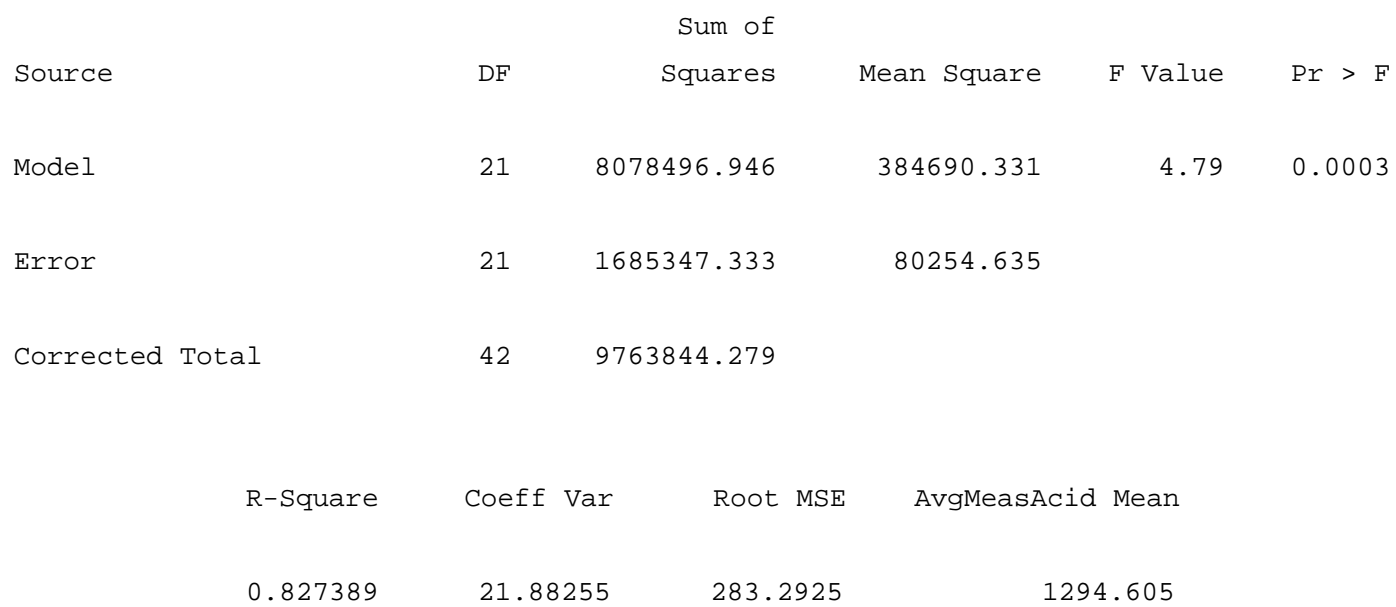

Source
Year
flowCategory
Year*flowCategory
season
Year*season
flowCategory*season
Year*flowCate*season

$\mathrm{DF}$

Type I SS

Mean Square

F Value $\operatorname{Pr}>\mathrm{F}$

Year*flowCate* season

\begin{abstract}
3453391.370
533259.955

1970378.955

1144292.973
\end{abstract}

1151130.457

266629.977

$14.34<.0001$

394075.791

3.320 .0558

4.910 .0039

$2.72 \quad 0.0706$

$2.04 \quad 0.0980$

163470.425

4.03

0.0577

Source

DF

Type III SS

Mean Square

F Value

$\operatorname{Pr}>\mathrm{F}$

Year

flowCategory

Year*flowCategory

season

Year*season

flowCategory* season

Year*flowCate* season

\begin{abstract}
2353955.541
263702.476

1197477.333

662394.684

581733.896

323408.333
\end{abstract}

784651.847

$9.78 \quad 0.0003$

131851.238

$1.64 \quad 0.2173$

598738.667

$7.46 \quad 0.0036$

220798.228

$2.75 \quad 0.0682$

145433.474

$1.81 \quad 0.1642$

323408.333

$4.03 \quad 0.0577$ 
NOTE: This test controls the Type I experimentwise error rate, but it generally has a higher Type II error rate than REGWQ.

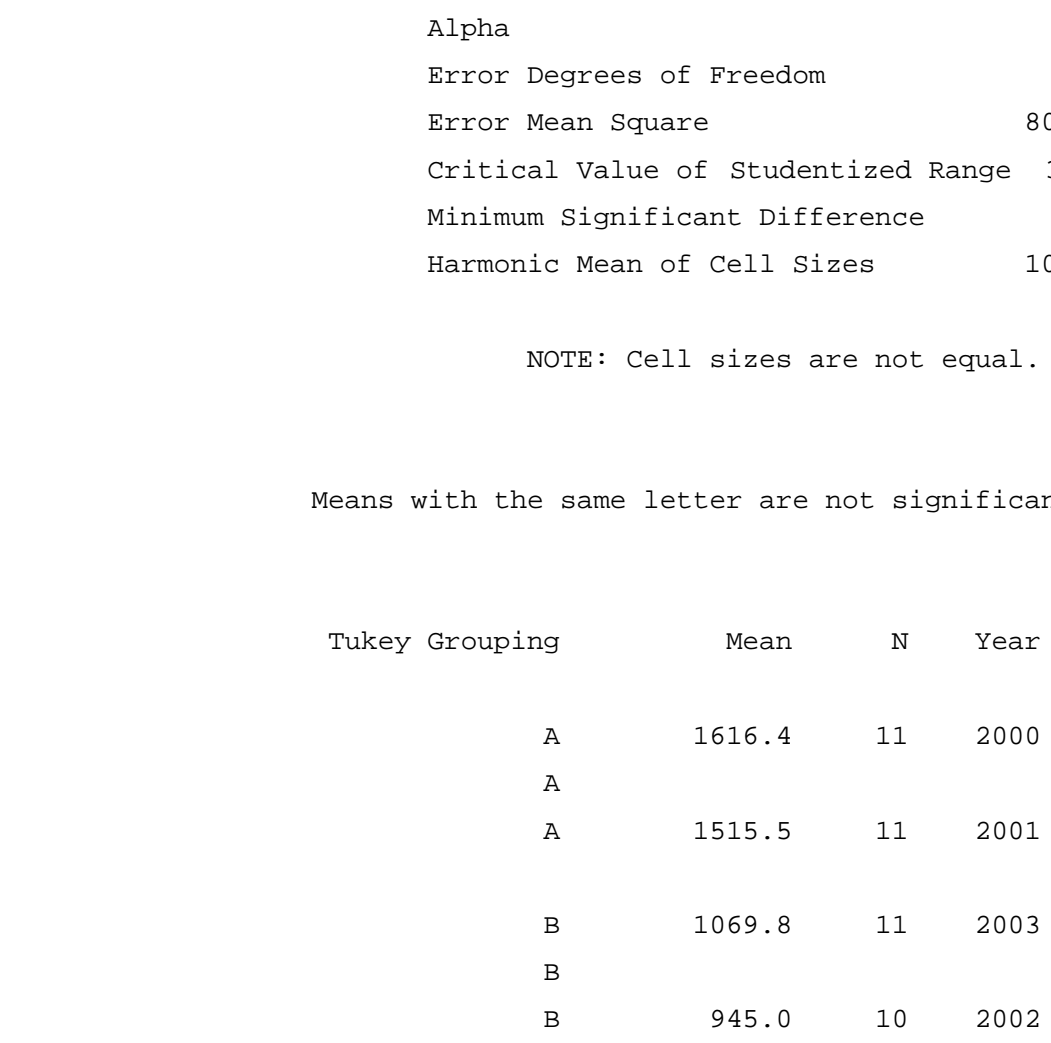

The GLM Procedure

Tukey's Studentized Range (HSD) Test for AvgMeasAcid

NOTE: This test controls the Type I experimentwise error rate, but it generally has a higher Type II error rate than REGWQ.

$\begin{array}{lr}\text { Alpha } & 0.05 \\ \text { Error Degrees of Freedom } & 21 \\ \text { Error Mean Square } & 80254.63 \\ \text { Critical Value of Studentized Range } & 3.56463 \\ \text { Minimum Significant Difference } & 267.72 \\ \text { Harmonic Mean of Cell Sizes } & 14.22801\end{array}$




$\begin{array}{rrrr}\text { Means with the same letter are not significantly different } \\ \text { fukey Grouping } & \text { Nean } & \text { Category } \\ \text { A } & 1518.7 & 14 & 1 \\ \text { B } & 1221.8 & 13 & 3 \\ \text { B } & & & \\ \text { B } & 1157.6 & 16 & 2\end{array}$

The GLM Procedure

Tukey's Studentized Range (HSD) Test for AvgMeasAcid

NOTE: This test controls the Type I experimentwise error rate, but it generally has a higher Type II error rate than REGWQ.

$\begin{array}{lr}\text { Alpha } & 0.05 \\ \text { Error Degrees of Freedom } & 21 \\ \text { Error Mean Square } & 80254.63 \\ \text { Critical Value of Studentized Range } & 3.94188 \\ \text { Minimum Significant Difference } & 342.49 \\ \text { Harmonic Mean of Cell Sizes } & 10.63087 \\ & \end{array}$

Means with the same letter are not significantly different.

$\begin{array}{rrrr}\text { Tukey Grouping } & \text { Mean } & \text { N } & \text { season } \\ \text { A } & 1383.0 & 12 & 4 \\ \text { A } & & & \\ \text { A } & 1317.5 & 11 & 2 \\ \text { A } & & & \\ \text { A } & 1256.7 & 9 & 1 \\ \text { A } & & & \\ \text { A } & 1206.4 & 11 & 3\end{array}$


Model: Average Flow * Year

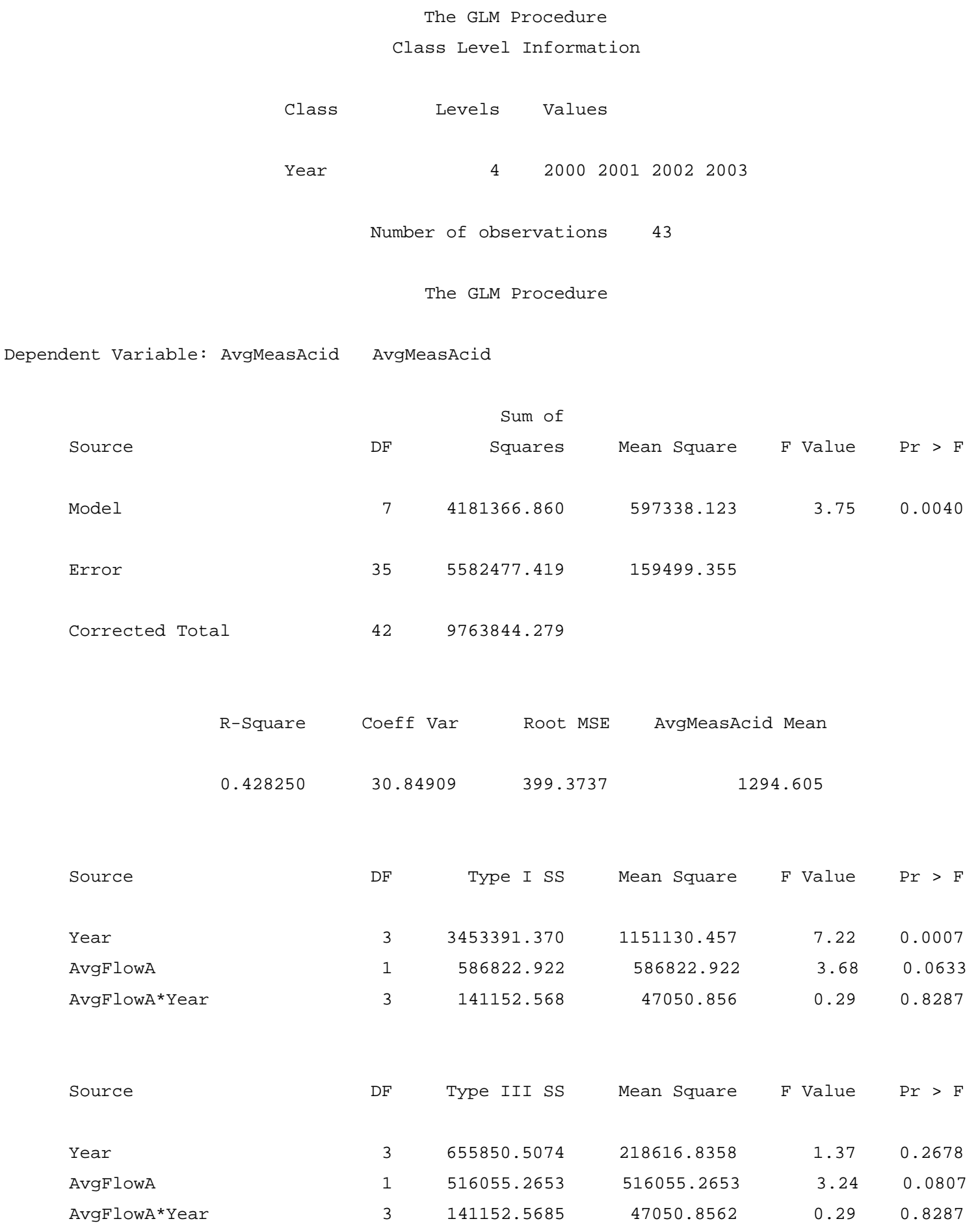


The GLM Procedure

Tukey's Studentized Range (HSD) Test for AvgMeasAcid

NOTE: This test controls the Type I experimentwise error rate, but it generally has a higher Type II error rate than REGWQ.

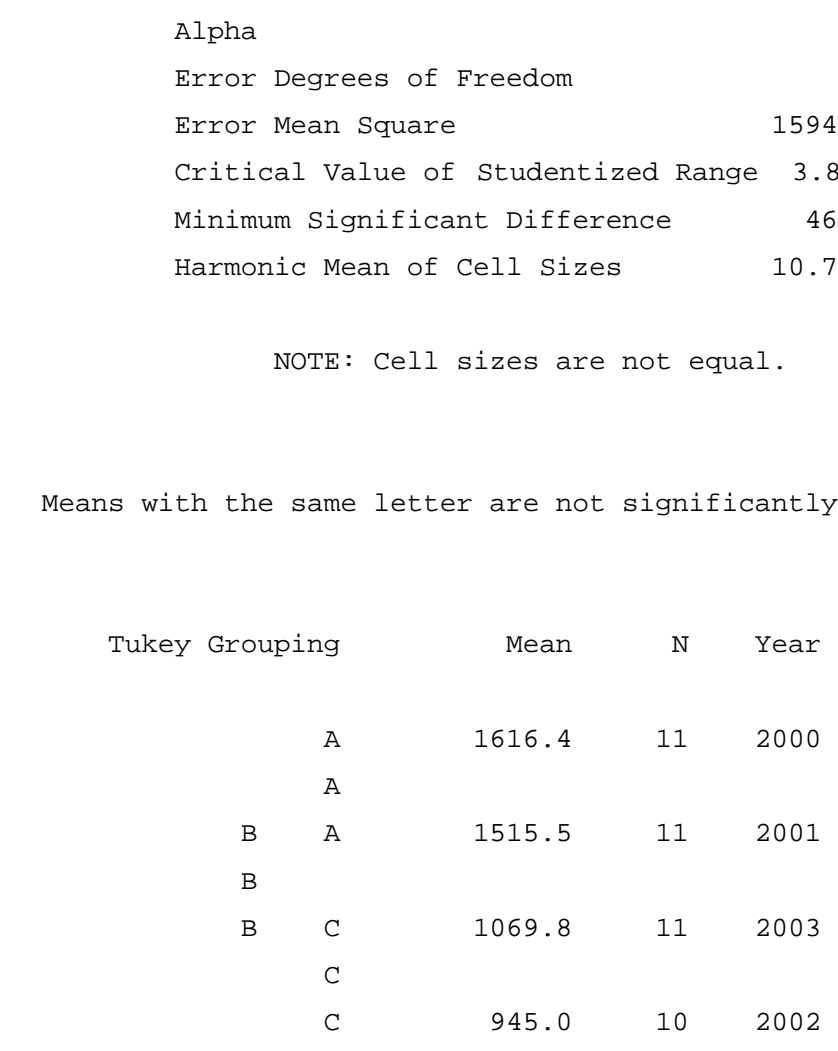

Model: Average Flow * Year * Season

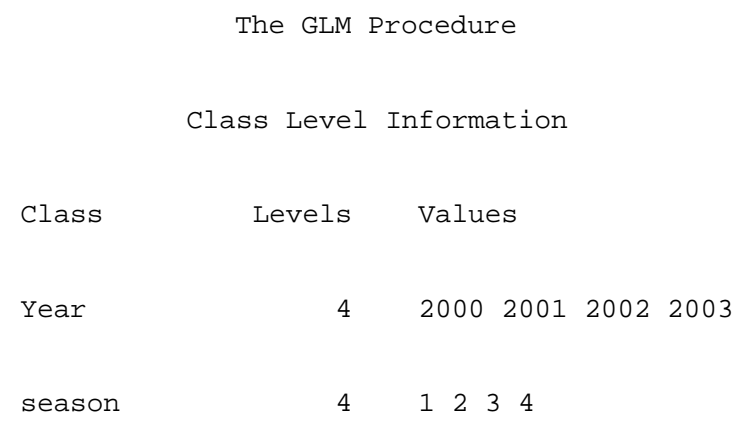


The GLM Procedure

Dependent Variable: AvgMeasAcid AvgMeasAcid

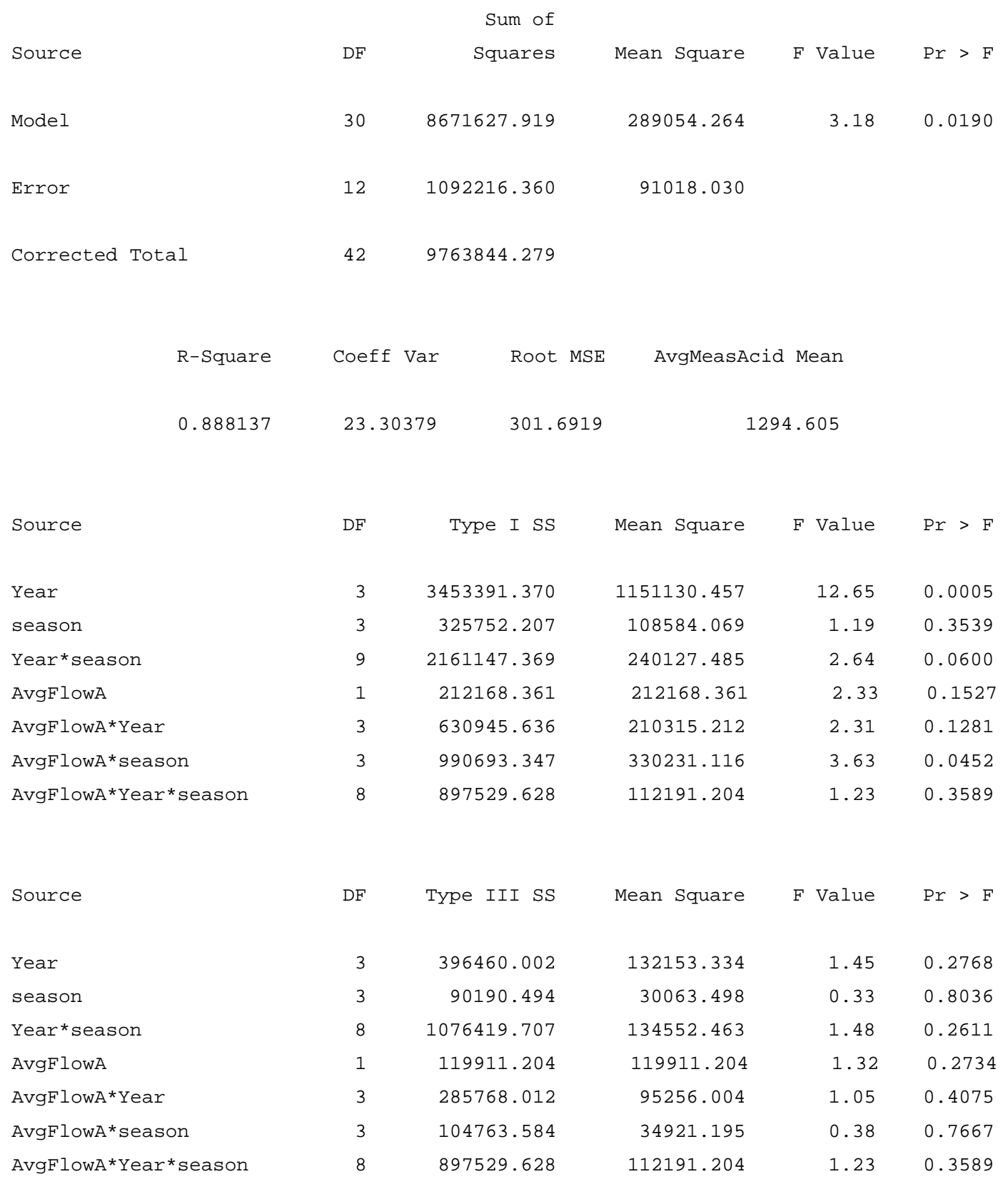


The GLM Procedure

Tukey's Studentized Range (HSD) Test for AvgMeasAcid

NOTE: This test controls the Type I experimentwise error rate, but it generally has a higher Type II error rate than REGWQ.

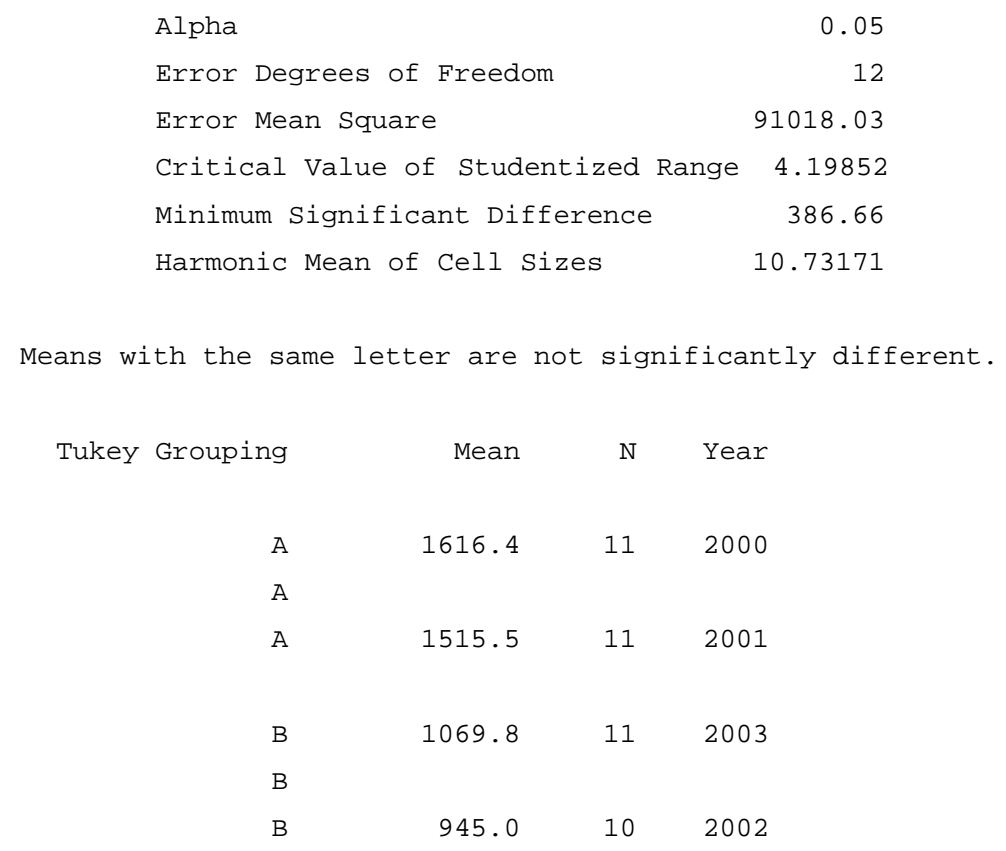

The GLM Procedure

Tukey's Studentized Range (HSD) Test for AvgMeasAcid

NOTE: This test controls the Type I experimentwise error rate, but it generally has a higher Type II error rate than REGWQ.

$\begin{array}{lr}\text { Alpha } & 0.05 \\ \text { Error Degrees of Freedom } & 12 \\ \text { Error Mean Square } & 91018.03 \\ \text { Critical Value of Studentized Range } & 4.19852 \\ \text { Minimum Significant Difference } & 388.49 \\ \text { Harmonic Mean of Cell Sizes } & 10.63087 \\ & \end{array}$




$\begin{array}{rrrr}\text { Tukey Grouping } & \text { Mean } & \text { N } & \text { season } \\ \text { A } & 1383.0 & 12 & 4 \\ \text { A } & & & \\ \text { A } & 1317.5 & 11 & 2 \\ \text { A } & & & \\ \text { A } & 1256.7 & 9 & 1 \\ \text { A } & & & \\ \text { A } & 1206.4 & 11 & 3\end{array}$

\section{Model: Average flow * Month}

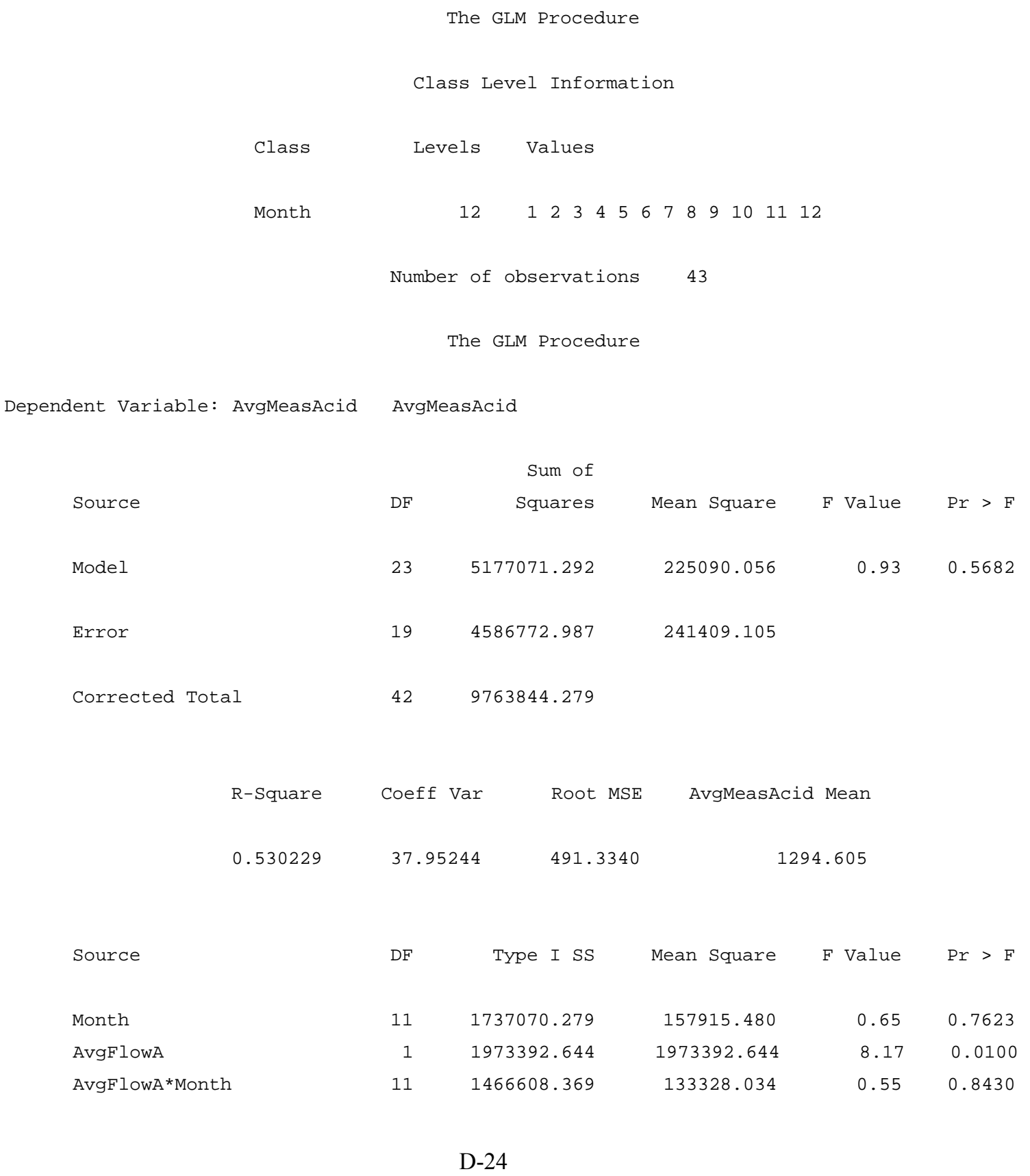




$\begin{array}{lrrrrr}\text { Source } & \text { DF } & \text { Type III SS } & \text { Mean Square } & \text { Value } & \text { Pr }>\text { F } \\ & & & & & 0.8647 \\ \text { Month } & 11 & 1387314.483 & 126119.498 & 0.52 & 0.85 \\ \text { AvgFlowA } & 1 & 205310.192 & 205310.192 & 0.3680 \\ \text { AvgFlowA*Month } & 11 & 1466608.369 & 133328.034 & 0.55 & 0.8430\end{array}$

The GLM Procedure

Tukey's Studentized Range (HSD) Test for AvgMeasAcid

NOTE: This test controls the Type I experimentwise error rate, but it generally has a higher Type II error rate than REGWQ.

$\begin{array}{lr}\text { Alpha } & 0.05 \\ \text { Error Degrees of Freedom } & 19 \\ \text { Error Mean Square } & 241409.1 \\ \text { Critical Value of Studentized Range } & 5.23083 \\ \text { Minimum Significant Difference } & 1388 \\ \text { Harmonic Mean of Cell Sizes } & 3.428571\end{array}$

Means with the same letter are not significantly different.

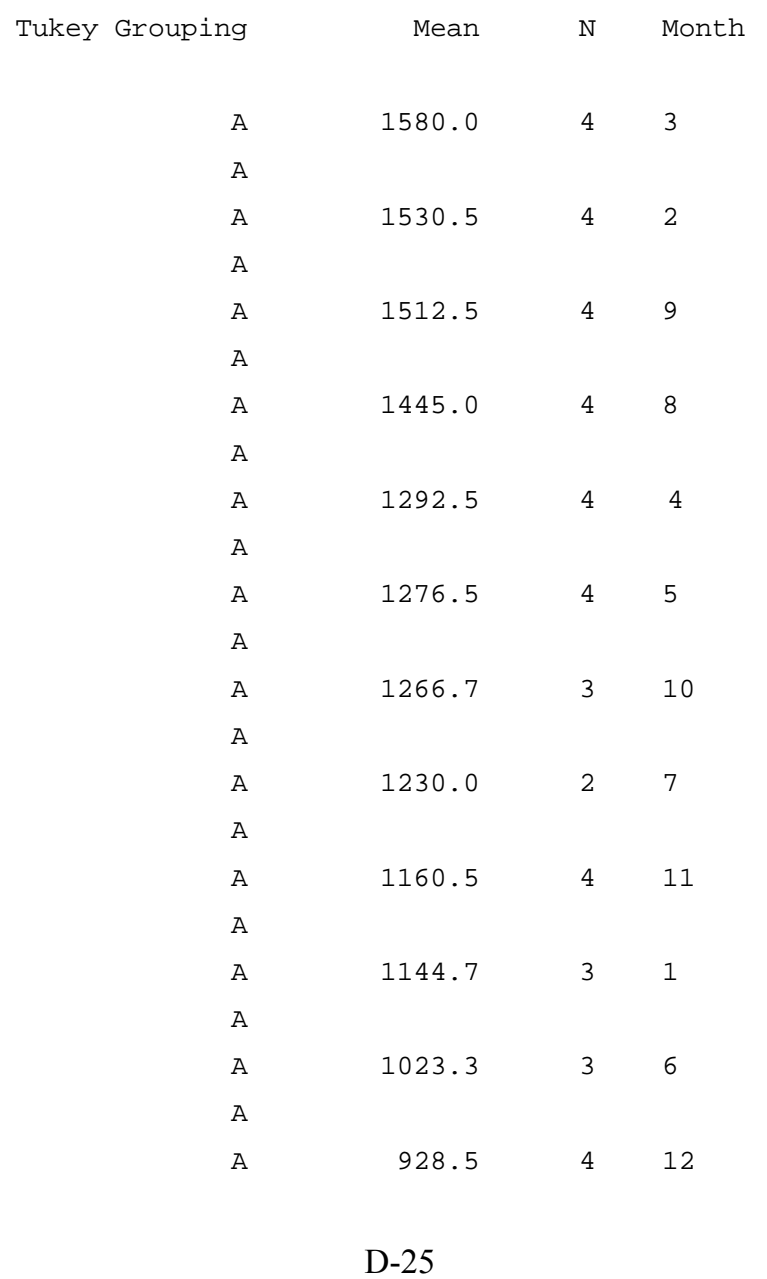




\section{Model: Average Precipitation * Flow Category}

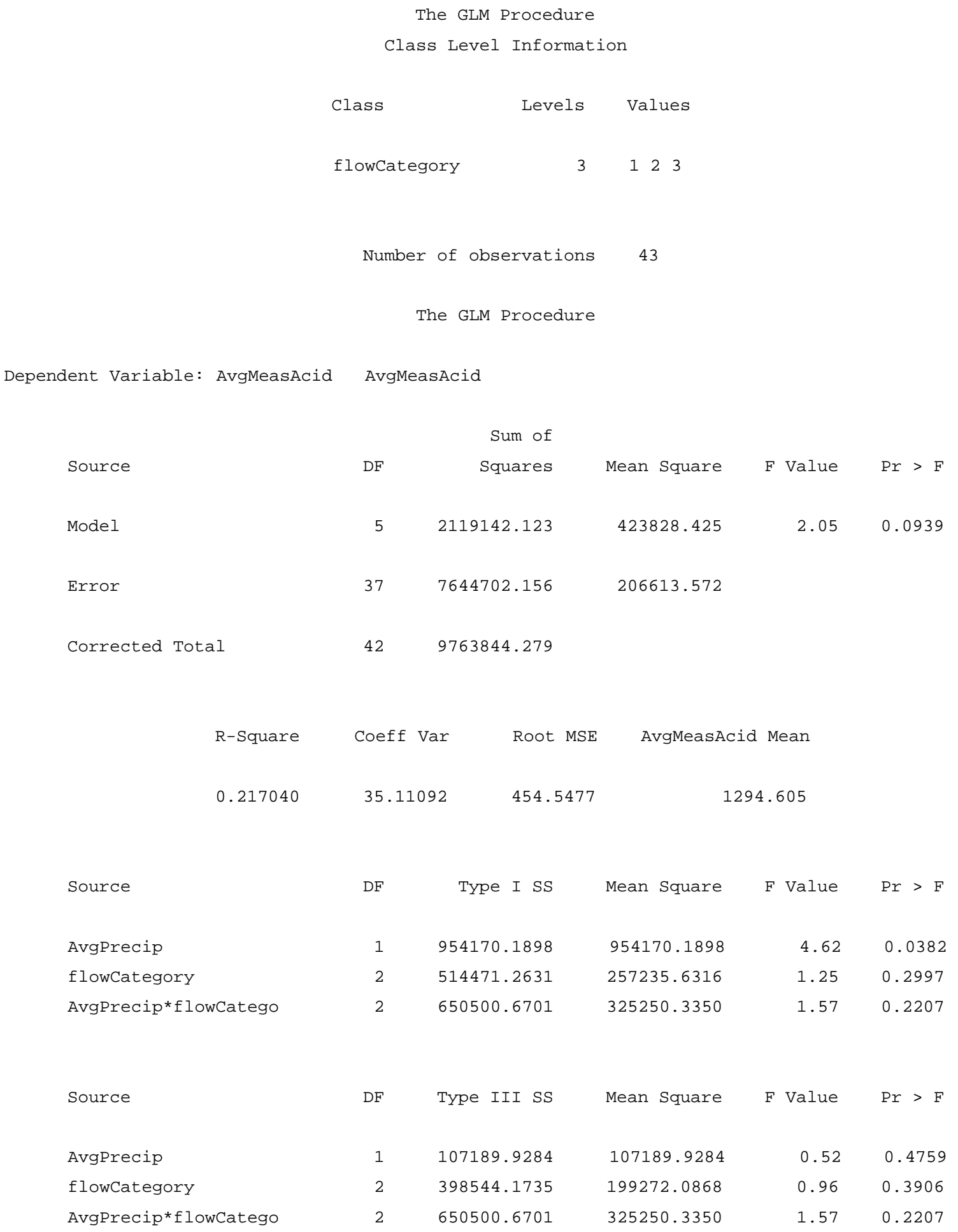


The GLM Procedure

Tukey's Studentized Range (HSD) Test for AvgMeasAcid

NOTE: This test controls the Type I experimentwise error rate, but it generally has a higher Type II error rate than REGWQ.

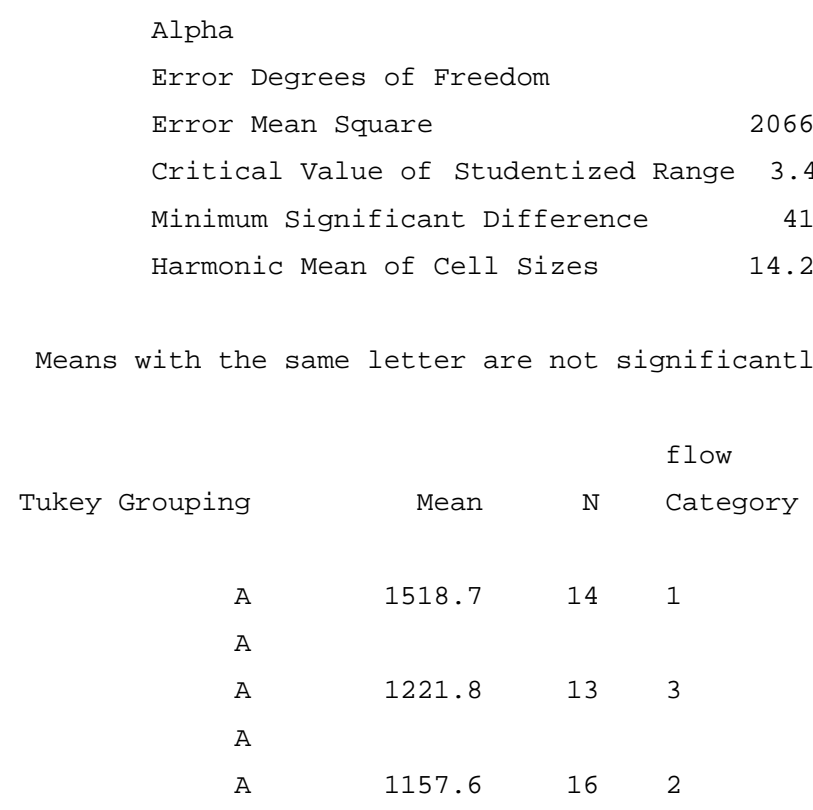

\section{Model: Average Flow * Average Precipitation}

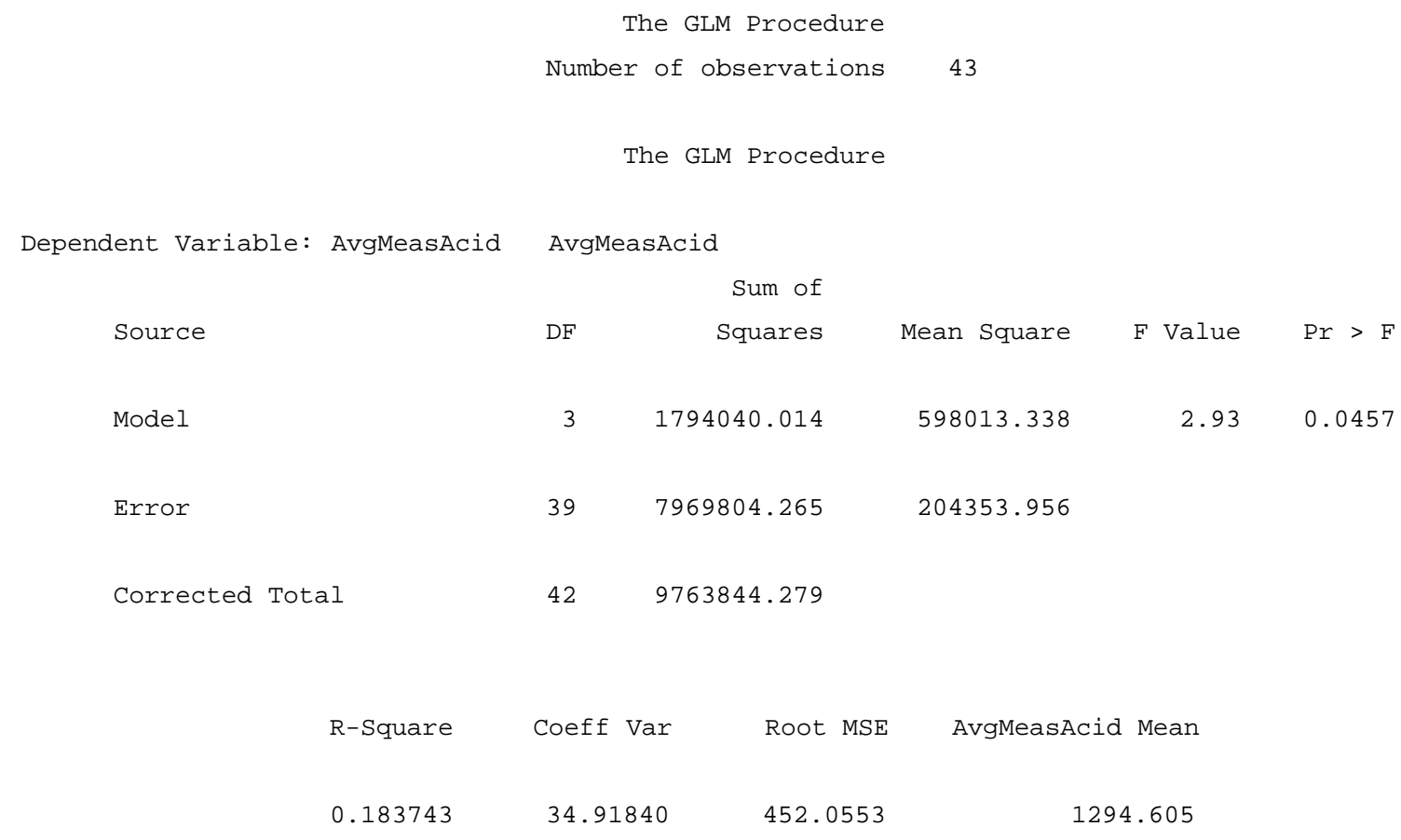




\begin{tabular}{|c|c|c|c|c|c|c|}
\hline Source & $\mathrm{DF}$ & Type I SS & Mean Square & $\mathrm{F}$ & Value & $\operatorname{Pr}>\mathrm{F}$ \\
\hline AvgPrecip & 1 & 954170.1898 & 954170.1898 & & 4.67 & 0.0369 \\
\hline AvgFlowA & 1 & 532122.3546 & 532122.3546 & & 2.60 & 0.1147 \\
\hline AvgPrecip*AvgF lowA & 1 & 307747.4697 & 307747.4697 & & 1.51 & 0.2271 \\
\hline Source & $\mathrm{DF}$ & Type III SS & Mean Square & $\mathrm{F}$ & Value & $\operatorname{Pr}>\mathrm{F}$ \\
\hline AvgPrecip & 1 & 4546.8421 & 4546.8421 & & 0.02 & 0.8822 \\
\hline AvgF lowA & 1 & 63030.3663 & 63030.3663 & & 0.31 & 0.5818 \\
\hline AvgPrecip*AvgFlowA & 1 & 307747.4697 & 307747.4697 & & 1.51 & 0.2271 \\
\hline
\end{tabular}

